\title{
ARE DIETARY FACTORS ASSOCIATED WITH LUNG FUNCTION IN CANADIAN ADULTS?
}

\author{
A Thesis Submitted to the College of \\ Graduate and Postdoctoral Studies \\ In Partial Fulfillment of the Requirements \\ For the Degree of
}

\section{Master of Science}

In the Department of Community Health and Epidemiology

College of Medicine

University of Saskatchewan

Saskatoon, SK, Canada

By

\section{Ulfat Ara Khanam}

(C) Copyright Ulfat Ara Khanam, December 2017. All rights reserved. 


\title{
Permission to use
}

In presenting this thesis in partial fulfillment of the requirements for a Postgraduate degree from the University of Saskatchewan, I agree that the Libraries of this University may make it freely available for inspection. I further agree that permission for copying of this thesis in any manner, in whole or in part, for scholarly purposes may be granted by the professor or professors who supervised my thesis work or, in their absence, by the Head of the Department or the Dean of the College in which my thesis work was done. It is understood that any copying or publication or use of this thesis or parts thereof for financial gain shall not be allowed without my written permission. It is also understood that due recognition shall be given to me and to the University of Saskatchewan in any scholarly use which may be made of any material in my thesis.

Requests for permission to copy or to make other use of material in this thesis in whole or part should be addressed to:

\author{
Department Head \\ Department of Community Health and Epidemiology \\ College of Medicine \\ University of Saskatchewan \\ 107 Wiggins Road \\ Saskatoon, Saskatchewan
}

S7N 5E5 


\begin{abstract}
Background: Assessment of lung function by spirometry is helpful for evaluating lung health. It provides precise measurements of air volumes and flows useful for diagnosis and monitoring of respiratory diseases. Respiratory diseases (including asthma and COPD) are some of the major causes of school and work absenteeism, hospital admission, disability, and death. Diet is a modifiable risk factor that has been associated with various respiratory outcomes but has been studied minimally in relation to lung function.
\end{abstract}

Purpose: The purpose of this study was to explore the impact of dietary factors and nutrient biomarkers on lung function among Canadian adults (18 years and older).

Methods: The Canadian Health Measures Survey (CHMS) is a national and ongoing health survey of Canadians led by Statistics Canada. CHMS uses a repeated cross-sectional multi-stage survey design. Data collection included a combination of a computer-assisted personal interview and physical assessment. The first Cycle (2007-2009) included N=3726, the second Cycle (2009-2011) included $\mathrm{N}=3873$, and the third Cycle (2012-2013) included $\mathrm{N}=3397$ adult Canadians. The physical measures were conducted at Mobile Examination Centers (MEC) specifically designed for the study. Spirometry measurement was completed by the eligible participants following spirometric guidelines of the American Thoracic Society (ATS). The household and clinic questionnaires were used to assess individual dietary factors, Canada Food Guide, and Modified Mediterranean Diet Score separately for each of the Cycles. Biomarker assessment was done by using blood samples. Association analyses were completed using multiple linear regression adjusting for age, sex, and height as well as other confounders using sampling weights. Bootstrapping variables supplied by Statistics Canada were used to calculate variances. 
Results: The overall mean percent predicted values for FVC and FEV1 were 98\% and 95\%, respectively. The associations between dietary consumption and lung function were relatively inconsistent. However, in both Cycles 1 and 2, consumption of dietary fat was associated with higher FVC ( $\mathrm{p}<0.05)$. In all Cycles, most of the participants did not meet the daily requirement of Canada Food Guide and the "not meeting" the requirements were inconsistently associated with the lower lung function. The modified Mediterranean Diet Score was significantly associated with lower lung function in Cycle 3. Among the biomarkers, chloride was associated with higher FVC and $\mathrm{FEV}_{1}$ for all three Cycles ( $\mathrm{p}<0.05$ ). C-reactive protein was associated with lower $\mathrm{FVC}, \mathrm{FEV}_{1}$,

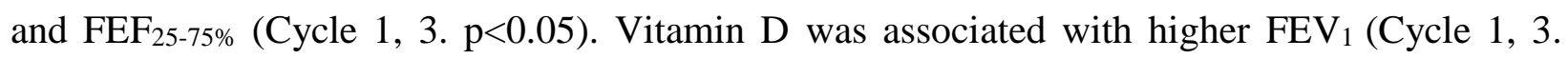
p <0.05). Finally, Vitamin B12 was associated with lower FEV 1 (Cycle 1, 3. p<0.05).

Conclusion: Lung function characteristics shows good lung health of the general adult population based on the mean percent predicted values. Our study provides evidence that there is an association between dietary factors and lung function though there were some inconsistencies with different Cycles (Cycles 1, 2, 3) mostly within the report of dietary intake. 


\section{Acknowledgement}

It is a great opportunity for me to thank those who made this thesis possible. First and foremost, I would like to express my sincere gratitude to the Almighty Allah, the most merciful and most beneficent, for giving me the opportunity and strength to learn and for His compassion throughout the study without which nothing could be accomplished.

I am grateful to my supervisor, Dr. Joshua Lawson, for his continuous guidance, support, tolerance, and inspiration without which it would not be possible to finish this thesis. He is not only my supervisor but also like my guardian in Canada. His comments and suggestions throughout the study were meant to be invaluable for the research. I would like to take the chance to appreciate the generosity and patience he showed during my master's study period, which helped me to study and work on my research in harmony.

I would like to express my sincere gratitude to my committee member, Dr. Donna Rennie, and Karen Davis (MCEd., RD., CRE) for constructive comments, information support and careful review, which helped to improve the quality of the thesis. I would like to express appreciation to my committee chair Dr. Bonnie Janzen for her valuable suggestions during my committee meetings.

Financial support provided by the Department of Community Health and Epidemiology (CH \& E), Canadian Center for Health and Safety in Agriculture (CCHSA), and Founding Chairs Fellowship to carry out this research is greatly acknowledged. I would like to express my appreciation to Statistics Canada for providing access to the Sky-RDC for the data of "Canadian Health Measures Survey (CHMS)". My sincere thanks to Dr. Ruben for his valuable support in 
using statistical software inside of RDC. Profound gratitude goes to Luan, Femi, Jinnat, and Rifat for their suggestions and useful tips.

I would like to convey my profound gratefulness to my parents (Akhand Md. Mukhlesur Rahman and Meherajun Nesa) and my parents in law (Md. Abdus Sobhan and Late Sufia Khatun) for their supports. Special thanks to my loving husband, Md. Shahabul Alam, for his continuous inspiration. Last but not the least, my sincere thanks to my brother (N H Manzur-E-Maula), sister (Zinat Ara), and sisters in law for their encouragements. 


\section{Table of Contents}

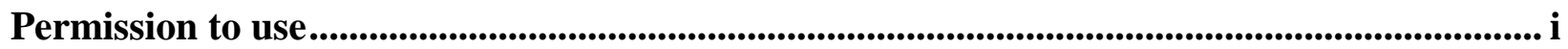

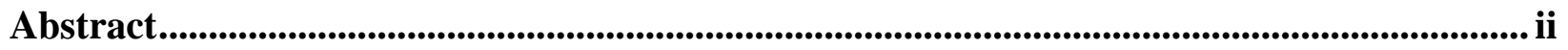

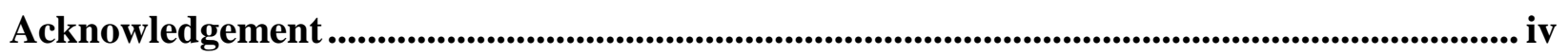

Table of Contents ................................................................................................................................. vi

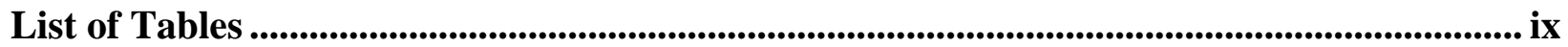

List of Figures........................................................................................................................................ $\mathrm{x}$

Chapter 1 : Introduction ....................................................................................................... 1

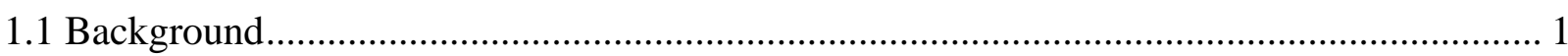

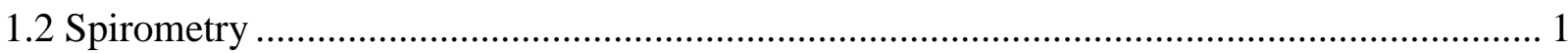

1.3 Dietary factors and its relationship to respiratory health.................................................. 2

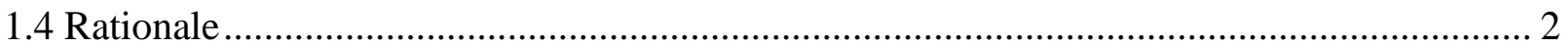

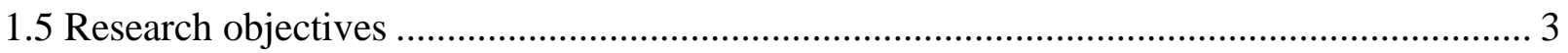

Chapter 2 : Literature review ................................................................................................ 4

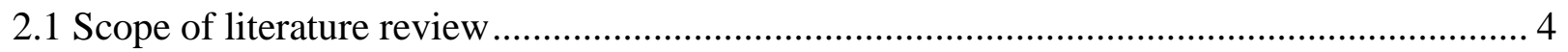

2.2 Methodology of the literature review …………………............................................... 4

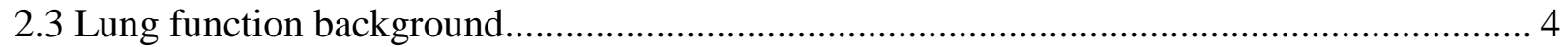

2.4 Burden of major respiratory diseases and the importance of lung function with regard to

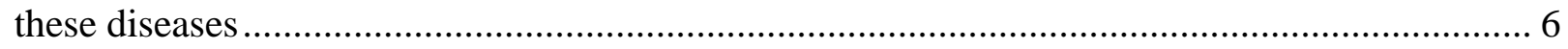

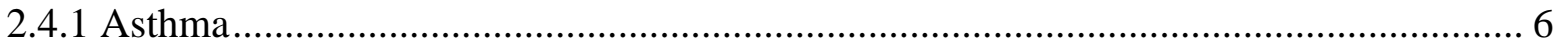

2.4.2 COPD

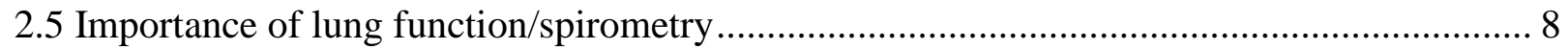

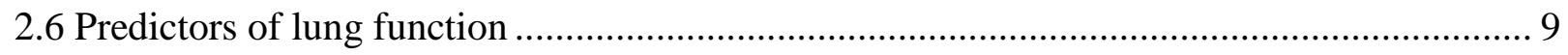

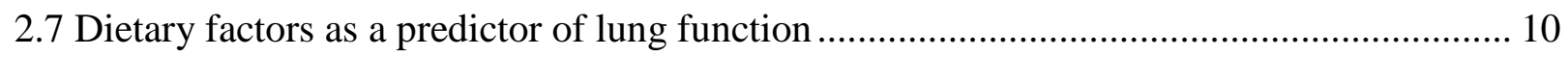

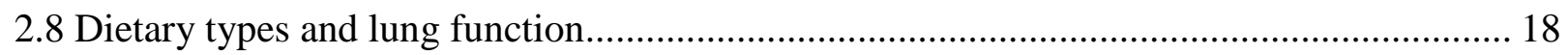

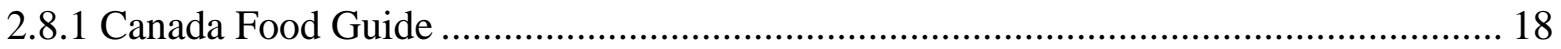

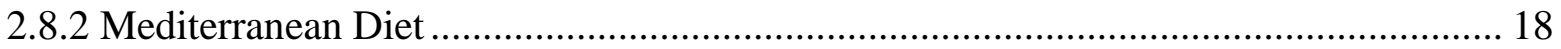

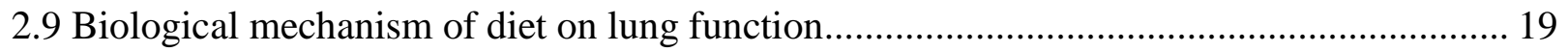

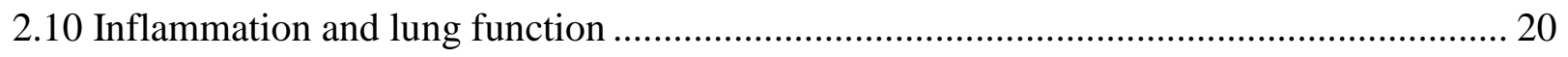

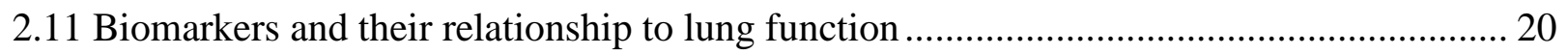

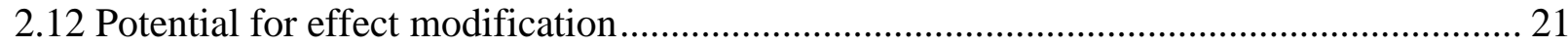

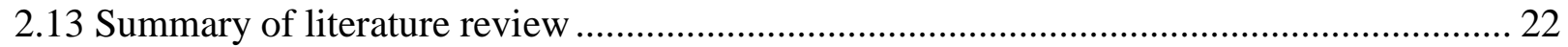




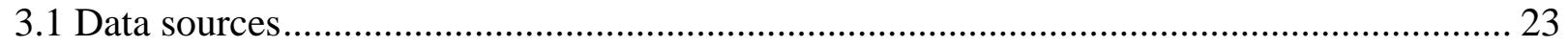

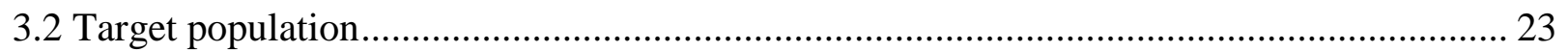

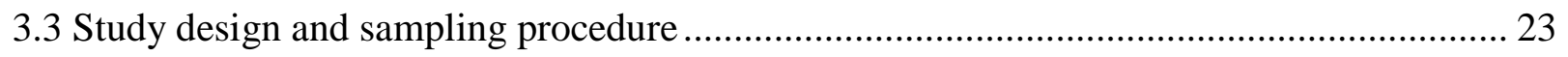

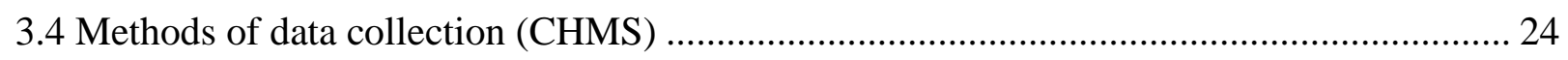

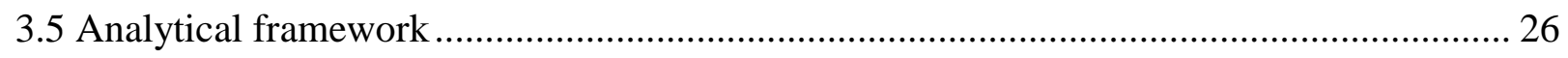

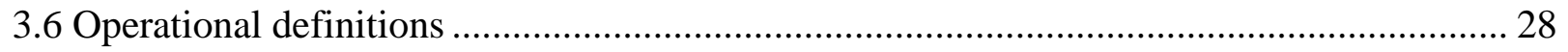

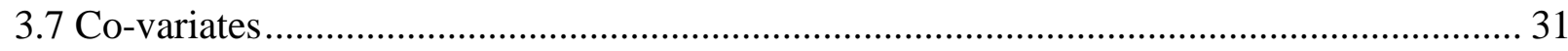

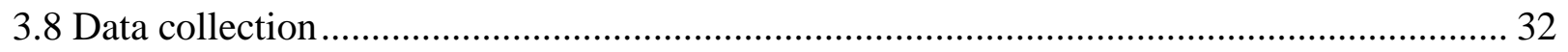

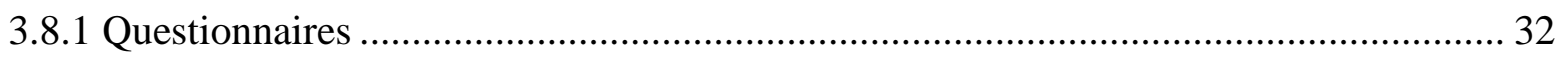

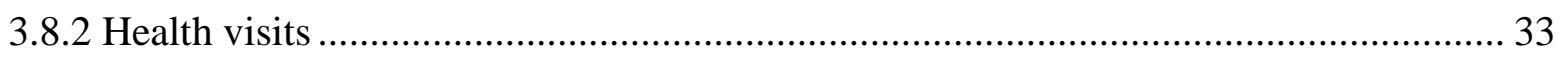

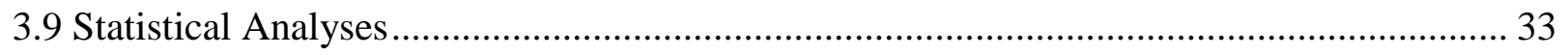

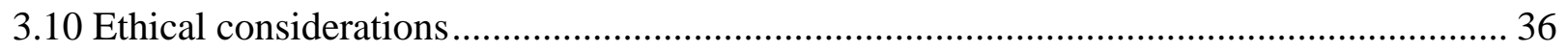

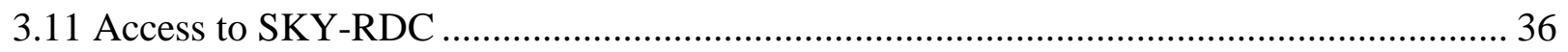

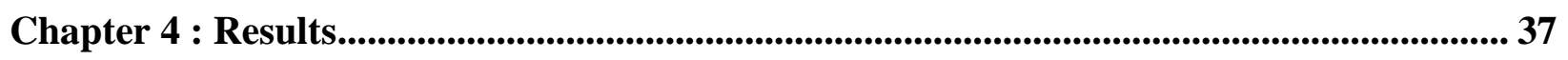

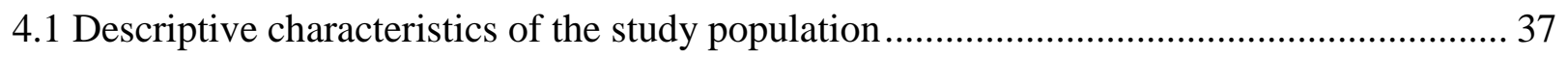

4.1.1 Demographic and personal characteristics ......................................................... 37

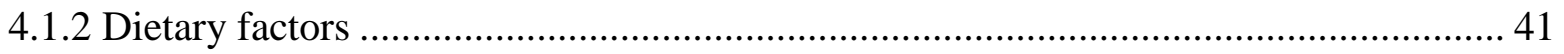

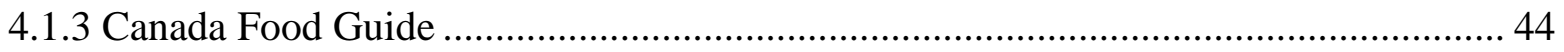

4.1.4 Mediterranean Diet and modified Mediterranean Diet Score .................................. 46

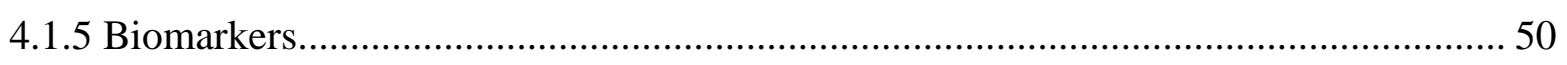

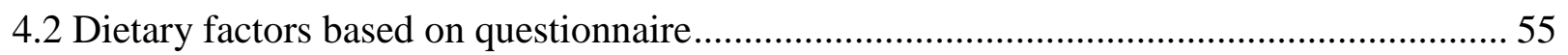

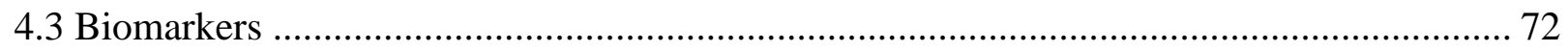

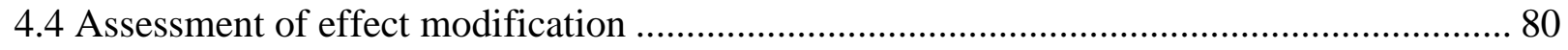

Chapter 5 : Discussion .................................................................................................................... 82

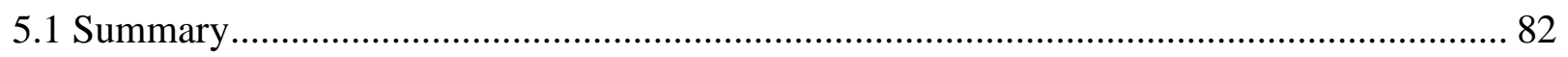

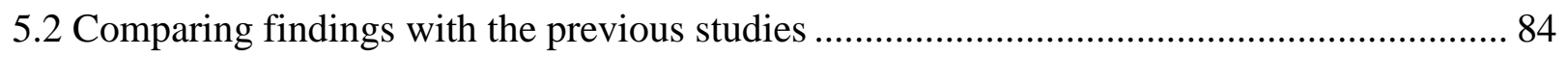

5.2.1 Individual food consumption and lung function................................................. 84

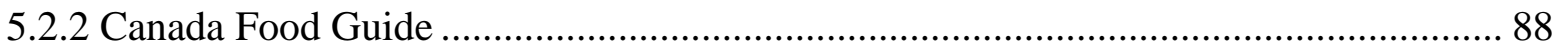

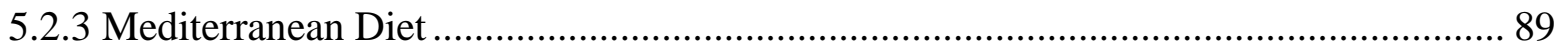

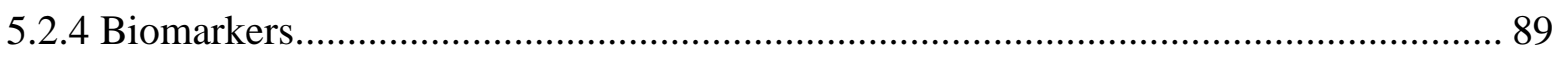

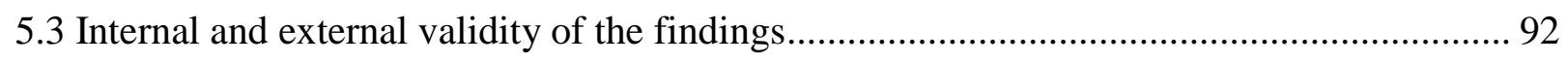




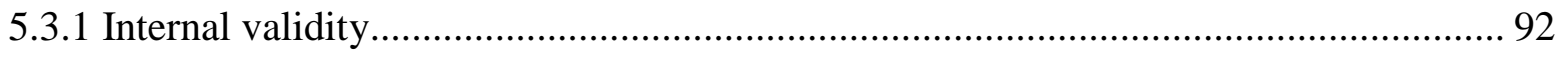

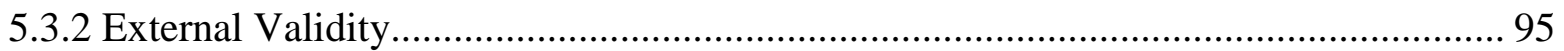

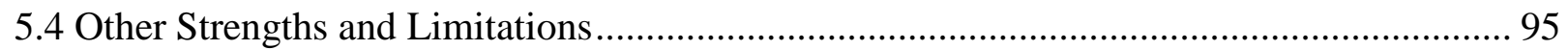

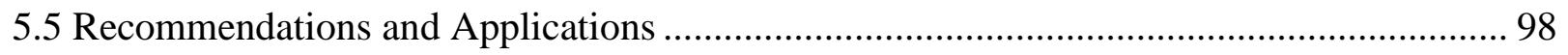

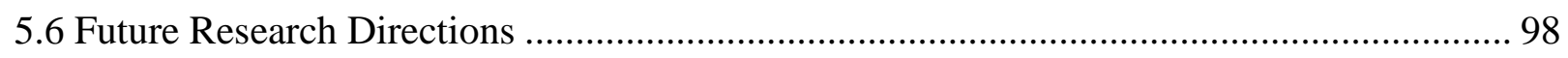

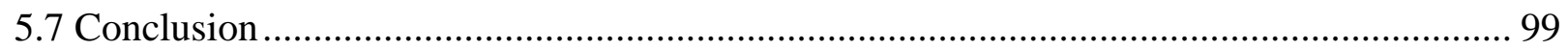

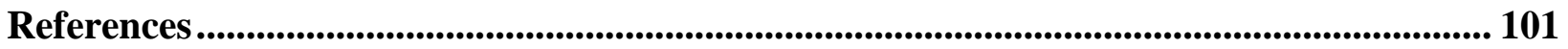

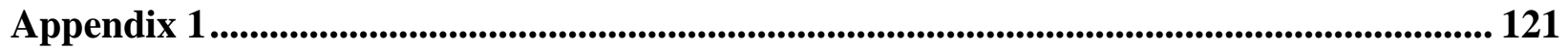

Appendix 2 ................................................................................................................................................. 136

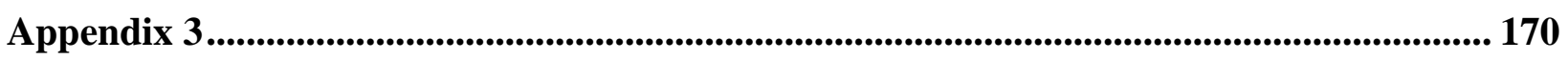

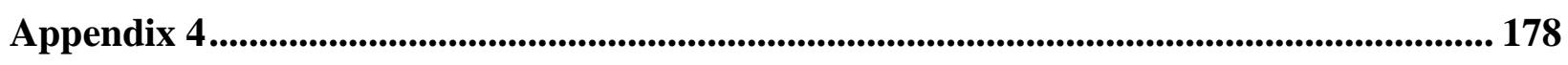




\section{List of Tables}

Table 2.1 Characteristics and results of studies investigating the association between dietary factors and lung function

Table 4.1 Descriptive statistics (overall) of socio-demographic, behavioral, and personal

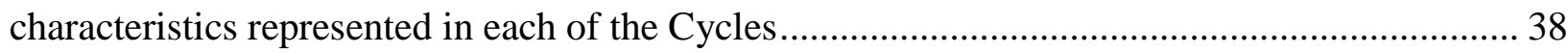

Table 4.2 Descriptive statistics of dietary factors (tertiles) represented in each of the Cycles .... 42

Table 4.3 Descriptive statistics (overall) of Canada Food Guide ………………….................... 45

Table 4.4 Descriptive statistics (overall) of Mediterranean Diet .......................................................4 47

Table 4.5 Modified Mediterranean Diet Score (overall) for all Cycles ......................................... 49

Table 4.6 Descriptive statistics (overall) of biomarkers for all Cycles......................................... 51

Table 4.7 Descriptive statistics of lung function status by age group adjusted* for sex, height,

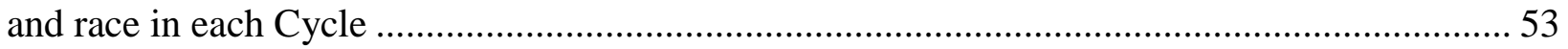

Table 4.8 Multivariate analysis of dietary factors, Canada Food Guide, and modified Mediterranean Diet Score with FVC …………………….................................................... 57

Table 4.9 Multivariate analysis of dietary factors, Canada Food Guide, and modified

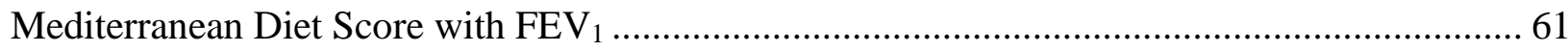

Table 4.10 Multivariate analysis of dietary factors, Canada Food Guide, and modified

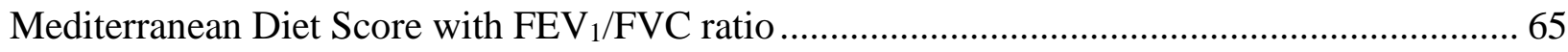

Table 4.11 Multivariate analysis of dietary factors, Canada Food Guide, and modified

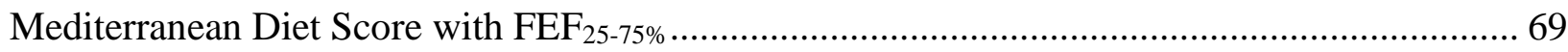

Table 4.12 Multivariate analysis of biomarkers with FVC........................................................ 73

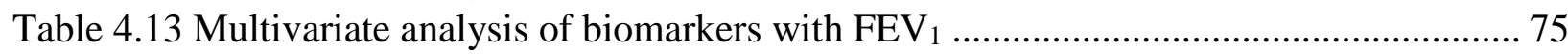

Table 4.14 Multivariate analysis of biomarkers with $\mathrm{FEV}_{1} / \mathrm{FVC}$ ratio .......................................... 77

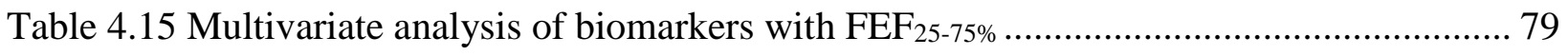

Table 4.16 List of significant interaction terms Cycle by Cycle ................................................ 80 


\section{List of Figures}

Figure 3.1 Analytical framework for dietary factors and lung function .............................. 27 


\section{Chapter 1 : Introduction}

\subsection{Background}

Chronic respiratory diseases can be defined as a group of chronic diseases which affect the airways and other structures of the lungs (1). The most common chronic respiratory diseases are asthma and chronic obstructive pulmonary disease (COPD) (1). For most lung diseases, evaluation of lung function by using spirometry is helpful in diagnosing lung disease, assessing severity, and determining prognosis. This is considered a standard method of lung health investigation. The specific etiology of these lung diseases is still unknown due to its multi-factorial nature, but both personal/genetic and environmental factors play a role, and this may also be true for predictors of lung function. Dietary intake is a modifiable behaviour. It has been shown to be a risk or protective factor for a number of respiratory diseases (2-7). By extension, lung function may also be affected by dietary intake.

\subsection{Spirometry}

Assessment of lung function can be conducted using spirometry which is the most common tool for clinical assessment of pulmonary function (8). A spirometer gives precise measurements of air volumes and flows useful for the diagnosis and monitoring of asthma and COPD (9). Forceful blowing into a spirometer while coached by a trained technologist provides various lung function parameters including Forced Vital Capacity (FVC), Forced Expiratory Volume in 1 second $\left(\mathrm{FEV}_{1}\right)$, Forced Expiratory Flow 25-75\% $\left(\mathrm{FEF}_{25-75 \%}\right)$, and the $\mathrm{FEV}_{1} / \mathrm{FVC}$ ratio $\left(\mathrm{FEV}_{1} / \mathrm{FVC}\right)$. It is important to note that lung function results can be influenced by both the individual as well as by the coaching of the technician. Validity and reliability of the testing must be considered. Through this assessment, abnormalities in lung function can be detected and used in the evaluation of lung health including the diagnosis and monitoring of various conditions. 
Interpretation of spirometry results can include a comparison between a person's measured value and reference or predicted values. It can also be considered as an absolute value (10).

\subsection{Dietary factors and its relationship to respiratory health}

Diet is one of the factors that can be modified by an individual's socio-economic status, lifestyle, environment, and ethnicity $(11,12)$. Individual dietary choices and habit may play a significant role in health (12). Similarly, dietary factors such as consumption of meat, fish, vegetables, fruits, and so on may have an impact on lung function. Recently, there has been increased attention on the role of diet in respiratory diseases (13-18). While some work has been conducted looking at the relationship between diet and specific disease conditions (14-23) there have been few studies conducted looking at diet in relation to lung function worldwide. Investigation into this work can be used for generating hypothesis and recommendations for further studies.

\subsection{Rationale}

Diet and nutrition are modifiable factors and if shown that they can contribute to the development and progression of chronic diseases (e.g. asthma, COPD), may be a potential intervention to improve health. Vegetables and fruits are beneficial for conditions related to respiratory system because these consist of antioxidants, vitamins, minerals, fibre, and phytochemical. Dietary antioxidants protect the airway against damaging effects of oxidative stress (24). There are several gaps in the scientific literature that should be addressed. These include:

- A very limited number of studies examining the relationship between diet and lung function $\left(\mathrm{FEV}_{1}, \mathrm{FVC}, \mathrm{FEV}_{1} / \mathrm{FVC}\right.$, and $\mathrm{FEF}_{25-75 \%}$ ) have been conducted with the general population (25-27). 
- In Canada, specifically, there have been no studies performed to explore the impact of dietary factors and biomarkers on lung function in a representative population of adults.

Statistics Canada is an ideal source for conducting this cost effective nutritional assessment in relation to lung function. Statistics Canada has collected a great deal of health and health behaviour information using standardized questionnaires as well as objective measurements (lung function and biomarkers) in a representative population through the Canadian Health Measures Survey (CHMS). CHMS is a multistage cross-sectional survey and has several Cycles (Cycles 1, 2, and 3). The main goal of the CHMS is to collect health information through a household interview and direct physical measures at a Mobile Examination Center to help improve health programs and services in Canada. It can also be used to help identify relationships between risk factors and health status, to explore emerging public health issues and to evaluate new measurement technologies.

\subsection{Research objectives}

The overall objective of this thesis is to identify the association between dietary factors and levels of lung function among adults. More specifically:

1. What are the characteristics/status of lung function $\left(\mathrm{FEV}_{1}, \mathrm{FVC}, \mathrm{FEV}_{1} / \mathrm{FVC}\right.$, and $\mathrm{FEF}_{25-}$ $75 \%)$ in Canadian adults (18-79 years)?

2. A) Are dietary factors (e.g. food types), dietary patterns (e.g. Mediterranean Diet), or biomarkers associated with lung function levels based on spirometry in a nationally representative Canadian population of adults?

B) Is there effect modification between dietary factors and asthma or COPD in the relationship with lung function? 


\section{Chapter 2 : Literature review}

\subsection{Scope of literature review}

The aim of the literature review was to explore the existing literature to describe and discuss what is already known about diet in relation to lung function. Similarly included in this literature review is a description of the methods used to assess lung function (spirometry), the prevalence of respiratory diseases, current knowledge about diet and lung function, and the evidence of beneficial and harmful effects of diet contributing to lung health.

\subsection{Methodology of the literature review}

The literature search was conducted between December 2014 and September 2017. Common search engines were used including Google Scholar, PubMed, Ovid MEDLINE, and Google search to look for current scientific publications and reports. Relevant scientific articles were also checked and included if they appeared in the reference section of a selected article. The keywords for the search were "lung function", "FVC", FEV1, "asthma", "COPD”, "respiratory disease", “diet", “dietary factors", "Mediterranean Diet", "Canada Food Guide”, "food intake”, "spirometry" meat", "fish", “egg", "milk", "beans", "vegetables", "fruits", and "soft drinks" "Vitamin D”, “calcium”, “chloride”, “C-reactive protein”, "red blood cell folate”, "Vitamin B12”, "potassium", "sodium" and combinations of these terms. The search was limited to humans only.

\subsection{Lung function background}

Spirometry is an objective measure of lung health and can be used for the assessment of diagnosis and monitoring. Various types of equipment can be used to conduct spirometry which requires cooperation between the individual and examiner. Interpretation of spirometry results can include a comparison between a person's measured value to the reference or predicted values based on similar age, sex, height, and ethnicity. Based on the use of cut-off points of percent predicted 
values, values can also be used as "normal" or "abnormal". Results can also be considered as an absolute value but should be adjusted for, at minimum, age, sex, and height.

Two of the more important aspects of spirometry are $\mathrm{FVC}$ and $\mathrm{FEV}_{1}$. FVC is a measurement of lung size (in liters) and represents the volume of air expired forcefully after taking a full and deep inspiration, while $\mathrm{FEV}_{1}$ is the volume of air delivered forcefully in the $1^{\text {st }}$ second of an FVC maneuver (28), (29).

The $\mathrm{FEV}_{1} / \mathrm{FVC}$ is the percent of lung volume (FVC) that can be exhaled in the $1^{\text {st }}$ second of forced expiration (28). This ratio can be used to help determine the diagnosis of obstructive and restrictive lung diseases (30). In obstructive lung disease, $\mathrm{FEV}_{1}$ is decreased due to the obstruction of air escaping from the lungs which leads to a lower $\mathrm{FEV}_{1} / \mathrm{FVC}$ ratio (8). The lower limit of normal for $\mathrm{FEV}_{1} / \mathrm{FVC}$ varies broadly. At a median age of between 42 and 48 years the lower limit of normal for $\mathrm{FEV}_{1} / \mathrm{FVC}$ is below 0.70 (30). Diagnosis of COPD can be confirmed if the $\mathrm{FEV}_{1} / \mathrm{FVC}$ ratio is below 0.70 and the $\mathrm{FEV}_{1}$ is below $80 \%$ of predicted (31). The $\mathrm{FEV}_{1} / \mathrm{FVC}$ ratio can also be used to aid in the diagnosis of asthma (32). The $\mathrm{FEV}_{1} / \mathrm{FVC}$ ratio is the most significant measure when evaluating obstruction (10) as well as predicting morbidity and mortality even though the $\mathrm{FEV}_{1}$ may be high (33). In restrictive lung disease such as lung fibrosis or other pathology (not obstructive), both $\mathrm{FEV}_{1}$ and $\mathrm{FVC}$ are reduced (8).

If the measured values of forced expiratory volume in the $1^{\text {st }}$ second $\left(\mathrm{FEV}_{1}\right)$ and forced vital capacity (FVC) are above $80 \%$ of the predicted value then generally this can be considered as "normal" and if it is below $80 \%$ then it can be considered as "abnormal" (10). Results of spirometry can be used to detect the presence and severity of respiratory diseases (e.g., asthma, COPD) by classifying the value of $\mathrm{FEV}_{1}$ into different stages such as from mild to very severe $(10,34)$ as well as through inspection of other characteristics of the spriometric output. Forced expiratory flow 25- 
$75 \%\left(\mathrm{FEF}_{25-75 \%}\right)$ is the average flow that is expired in the middle half of the $\mathrm{FVC}$ which represents the status of the small and medium airways (29). The value of $\mathrm{FEF}_{25-75 \%}$ can be decreased in the earlier stage of obstructive lung disease (e.g. asthma) (35). $\mathrm{FEF}_{25-75 \%}$ values are more variable than $\mathrm{FEV}_{1}$ and $\mathrm{FVC}$. In addition, $\mathrm{FEF}_{25-75 \%}$ is dependent on FVC. Therefore, use of this measure is not as valid as $\mathrm{FEV}_{1}$ and $\mathrm{FVC}(29)$.

\subsection{Burden of major respiratory diseases and the importance of lung function with regard}

\section{to these diseases}

Asthma and COPD are important respiratory diseases due to high prevalence, morbidity, mortality, economic costs, and loss of productivity (36-38). Details about the burden of these two respiratory diseases are discussed below:

\subsubsection{Asthma}

According to the Global Initiative of Asthma (GINA) 2015 definition, asthma "is a heterogeneous disease, usually characterized by chronic airway inflammation. It is defined by the history of respiratory symptoms such as wheeze, shortness of breath, chest tightness and cough that vary over time and in intensity, together with variable expiratory airflow limitation" (39).

The prevalence of asthma has been increasing during the last few decades (40). Asthma is the twenty-second most important disorder in the world in terms of disability adjusted life years (DALYs) (1). Based on the recent report of the "Global Asthma Report 2014", the burden of asthma is highest for children aged 10-14 years and the older persons aged 75-79 years and lowest for those aged 30-34 years as measured by disability and premature death (41). The high prevalence of asthma symptoms among the older population might also be due to the presence of other respiratory diseases such as Chronic Obstructive Pulmonary Disease (COPD) (41). 
The global prevalence of asthma among young adults (18-45 years) is approximately $8.6 \%$ (41). Among the Canadian population, more than 2.4 million (8.4\%) people aged 12 years or older had asthma in 2009-2010 (42). About $7.0 \%$ of males and 9.8\% of females are living with asthma in Canada (42). Asthma is one of the major causes of school and work absenteeism as well as hospital admission (36).

In British Columbia, the estimated direct asthma-related health care costs including hospitalization, physician visits, and medication use were $\$ 315.3$ million between 2002 and 2007 (43). Annual costs per patient with current asthma were $\$ 311$ and for patients who ever had asthma, it was $\$ 159$ (43).

\subsubsection{COPD}

According to the Global Initiative for Chronic Obstructive Lung Diseases (GOLD) 2017, COPD is defined as "a common, preventable, and treatable disease that is characterized by persistent respiratory symptoms and airflow limitations that are due to airway and/or alveolar abnormalities usually caused by significant exposure to noxious particles or gases" (44).

COPD is the tenth most important disorder in the world in terms of disability adjusted life years (DALYs) (1). Globally, COPD was estimated as the $5^{\text {th }}$ leading cause of death in 2001 and will be the $3^{\text {rd }}$ leading cause of death by 2020 as stated by the World Health Organisation's (WHO) Global Burden of Disease Project (45). The prevalence ranges in women from 5.1\% (China) to $16.7 \%$ (South Africa) and in men from $8.5 \%$ (Iceland) to $22.2 \%$ (South Africa) (46). The prevalence of COPD in Canada (Vancouver) is approximately 7.3\% in women and 9.3\% in men (46). 
The average excess costs due to COPD were about $\$ 5,452$ per patient per year which was 2.73 times higher than non-COPD patients (47). It was estimated in British Columbia that the total excess costs for COPD patients were $\$ 600$ million in 2010 (47).

\subsection{Importance of lung function/spirometry}

Use of spirometry is helpful for severity assessment of respiratory diseases (48). Spirometry provides acceptable results and accurate interpretations which can be incorporated in medical practice in the management of patients with previously diagnosed asthma or COPD. To assess the impact of spirometry in the management of asthma and COPD patients, an introduction of office spirometry was established in community based family medicine practices in USA by using a before and after quasi-experimental design (9). The researchers randomly selected 12 nonacademic family medicine practices without prior use of in-office spirometry and introduced an EasyOne Spirometer (ndd Medizintechnik AG; Zurich, Switzerland). The researchers enrolled patients aged $>7$ years and previously diagnosed with asthma or COPD for spirometry as an everyday practice. The "pre" data was the recommended therapy without use of spirometry and the "post" was the interpretation of the spirometry results by using complete assessment of the patients' condition with spirometry, symptoms, and a medication checklist questionnaire. Based on the spirometry results, the physicians interpreted and changed the medications as required. The investigators sent the spirometry results with the family physician's interpretation to the experts for reviewing. This was to evaluate the consistency of the current medication changes based on spirometry. The combination of before and after information regarding patient reported symptoms, spirometry results, and before and after medications helped them in judging the consistency in changing medication therapy to the standard guidelines. They found consistent management (overall $86 \%$ of the medication changes after using spirometry) which support the Global Initiative 
Chronic Obstructive Lung Disease guidelines for the management of COPD and National Asthma Education and Prevention Program guidelines for the management of asthma (9).

\subsection{Predictors of lung function}

Several factors are predictors of lung function. The value of FVC increases with increasing age until 24 years, then it remains stable through the age of approximately 34 years until decreasing in older age (49). It was found that rising age is associated with decreasing $\mathrm{FEV}_{1}$ and $\mathrm{FVC}$ among adults aged $\geq 65$ years (50) and declining lung function may accelerate after the age of 70 years (51). This association has been observed in Caucasian and African-American population (50). On average, African-American persons have lower $\mathrm{FVC}$ and $\mathrm{FEV}_{1}$ compared to Caucasian persons at all ages and sexes (49). Height is another important predictor of lung function where lung function increases with increasing height (52). The growth of lung function is better observed in relation to height rather than age in children and adolescents (boys aged 7-17 years, girls aged 7-14 years) (49). Greater values of lung function are observed in young males than young females with the same standing height (52). Again, African-American persons had lower values of lung function (FVC) for the same sex and height groups than Caucasian persons (49). Immigration status may have an impact on lung function as lung function varies in different ethnicities and geographic areas (53). Lower socioeconomic status acts as a risk factor for asthma and other chronic diseases $(54,55)$. Similarly, lower socio economic status is associated with lower lung function $(54,55)$. The presence of chronic bronchitis, pneumonia, emphysema, and asthma are also associated with decreasing levels of lung function (50). Many studies have been reported that lower respiratory tract infection and smoking (active and passive) by healthy children, adolescents, and adults are associated with reduced levels of lung function (56-62). The effect of smoking may slow the growth of lung function in both sexes, with a greater effect observed in girls than boys (62). 
Bronchial hyper-responsiveness may be associated with accelerated reducing of $\mathrm{FEV}_{1}(63,64)$. Recently a population based study in 2015 among adults aged $\geq 20$ years has shown that weight, body mass index, waist circumference, waist-hip ratio, and abdominal height is associated with the higher $\mathrm{FEV}_{1} / \mathrm{FVC}$ ratio (65). In this study, $\mathrm{BMI}$ was the strongest predictor of $\mathrm{FEV}_{1} / \mathrm{FVC}$ ratio in both men and women (65). Obesity may cause difficulty in respiration by providing limited space for descending of the diaphragm and compromises chest wall may lead to diminishing functional residual capacity and total lung capacity followed by reducing lung function levels (66). Obesity may occur in improper dietary consumption, malnutrition, and lack of physical activity.

\subsection{Dietary factors as a predictor of lung function}

Changing dietary habits may act as a factor to explain the increase in severity and prevalence of asthma $(2,67)$. The prevalence of asthma has increased in parallel with changes in diet, urbanization, and westernization in the past few decades $(13,68)$. The prevalence of COPD has also increased with smoking, dietary habit, urbanization, and westernization (69-74). One interpretation requiring further research is that the rising prevalence of lung disease may be due to the altering of dietary habits (4-7). For example, in the UK, the most common dietary pattern identified in an observational study by Devereux and Seaton was a lower intake of fruits and vegetables, and higher intake of fatty food (e.g. margarine) (75). They showed a trend in the UK dietary pattern between 1942 and 2000 suggesting that consumption of fresh green vegetables, total vegetables, and potatoes had been reduced (75). Their review also showed that there are beneficial associations in the consumption of dietary antioxidants (Vitamin A, E, and C) and lipids (e.g. fatty fish) with asthma and atopy according to the epidemiologic studies (75-77).

Dietary consumption may vary from person to person due to socio-demographics, social status, geography, ethnicity, and lifestyle $(11,12)$. Given the recognized importance of diet, there has been 
increased attention on the health effects of dietary factors with regard to lung health recently, including lung function. A description of dietary characteristics as an exposure and lung function as an outcome from various studies is presented in Table 2.1 . 
Table 2.1 Characteristics and results of studies investigating the association between dietary factors and lung function

\begin{tabular}{|c|c|c|c|c|}
\hline $\begin{array}{l}\text { First author } \\
\text { reference\# (Year } \\
\text { published) } \\
\text { Location }\end{array}$ & $\begin{array}{l}\text { Study } \\
\text { Design }\end{array}$ & $\begin{array}{l}\text { Study population } \\
\text { (Sample size) }\end{array}$ & Diet exposure & Outcome and strength of association \\
\hline
\end{tabular}

\begin{tabular}{|c|c|c|c|c|}
\hline $\begin{array}{l}\text { Sorli- } \\
\text { Aguilar, M } \\
(78) \\
2016 \\
\text { Spain }\end{array}$ & $\begin{array}{l}\text { Cross- } \\
\text { sectional }\end{array}$ & $\begin{array}{l}\text { Adults 35-70 } \\
\text { years (n=207) } \\
\text { without } \\
\text { respiratory } \\
\text { symptoms, } \\
\text { smoker, } \\
\text { previously } \\
\text { diagnosed with } \\
\text { respiratory } \\
\text { disease were } \\
\text { excluded. }\end{array}$ & $\begin{array}{l}45 \text { item of food (grouped } \\
\text { into } 19 \text { based on the } \\
\text { similarity of food) } \\
\text { frequency questionnaire. } \\
\text { The score for the dietary } \\
\text { patterns was characterized } \\
\text { into tertiles. }\end{array}$ & $\begin{array}{l}\text { The alcohol consumption pattern was associated with impaired lung } \\
\text { function in both men and women. But higher odds ratio was observed in } \\
\text { women (OR: } 11.47,95 \% \text { CI: } 2.25-58.47 \text {, p-value: } 0.003) \text {. } \\
\text { The westernized pattern was associated with a higher risk of impaired } \\
\text { lung function only in women (OR: } 5.62,95 \% \text { CI: } 1.17-27.02 \text {, p-value: } \\
0.031 \text { ). } \\
\text { The Mediterranean Dietary like pattern was associated with preserved } \\
\text { lung function (OR: } 0.71 ; 95 \% \text { CI: } 0.28-1.79) \text {. }\end{array}$ \\
\hline
\end{tabular}

స̃ Hanson, C Cross(27) sectional

2016

USA

Niruban, S J Cross-

(79) sectional

2015

Canada excluded.

Adults 40-79

years $(\mathrm{n}=1,921)$.

NHANES Cycle

2009 to 2010 who

had pre-

bronchodilator

spirometry.

Adolescents and

adults aged 13-69

years

$(\mathrm{n}=3,735)$ with

25(OH)D

measurements

and valid lung

function

measurements.
Dietary intake of total fiber was calculated based on 24 hours recall interview of the participants

Higher fiber intake was associated with higher proportion of normal lung function (p-value 0.001).

There was no association between daily intake of whole grains and lung function.

Serum 25-hydroxy

Vitamin D $\{25(\mathrm{OH}) \mathrm{D}\}$

level (categorized into

$\leq 49 \mathrm{nmol} / \mathrm{L}$ as low, 50 -

$70 \mathrm{nmol} / \mathrm{L}$ as moderate, and $\geq 75 \mathrm{nmol} / \mathrm{L}$ as high) with low $25(\mathrm{OH}) \mathrm{D}$ category and lower mean values of $\mathrm{FVC}, \mathrm{FEV}_{1}$,
There was statistically insignificant association detected in the mean values of actual and percent predicted $\mathrm{FEV}_{1}, \mathrm{FVC}$, and $\mathrm{FEF}_{25 \%-75 \%}$ and the three categories of $25(\mathrm{OH}) \mathrm{D}$, while the mean $\mathrm{FEV}_{1} / \mathrm{FVC}$ was lowest in the high $25(\mathrm{OH}) \mathrm{D}$ and highest in the low $25(\mathrm{OH}) \mathrm{D}$ which was not observed in the percent predicted $\mathrm{FEV}_{1} / \mathrm{FVC}$ ratio. Non- significant results were found

$\mathrm{FEV}_{1} / \mathrm{FVC}$, and $\mathrm{FEF}_{25 \%-75 \%}$ after adjusting for age, gender, height, weight, smoking status, and race. Significant association found between high category of $25(\mathrm{OH}) \mathrm{D}$ and lower mean values of $\mathrm{FEV}_{1} / \mathrm{FVC}$ (p-value 0.02 ) than moderate category of $25(\mathrm{OH}) \mathrm{D}$ with mean values of $\mathrm{FEV}_{1} / \mathrm{FVC}$ 


\begin{tabular}{|c|c|c|c|c|}
\hline $\begin{array}{l}\text { Wroblewska, } \\
\text { I } \\
(80) \\
2015 \\
\text { Poland }\end{array}$ & $\begin{array}{l}\text { Medical } \\
\text { document } \\
\text { (spirometry) } \\
\text { analysed } \\
\text { (between } \\
\text { January and } \\
\text { December } \\
\text { 2012) }\end{array}$ & $\begin{array}{l}\text { Hospitalised } \\
\text { patients } \geq 65 \text { years } \\
\text { with respiratory } \\
\text { system disorder } \\
(n=217) .\end{array}$ & $\begin{array}{l}\text { Normal diet, easily } \\
\text { digestible diet, diabetic } \\
\text { diet, liver disease diet }\end{array}$ & 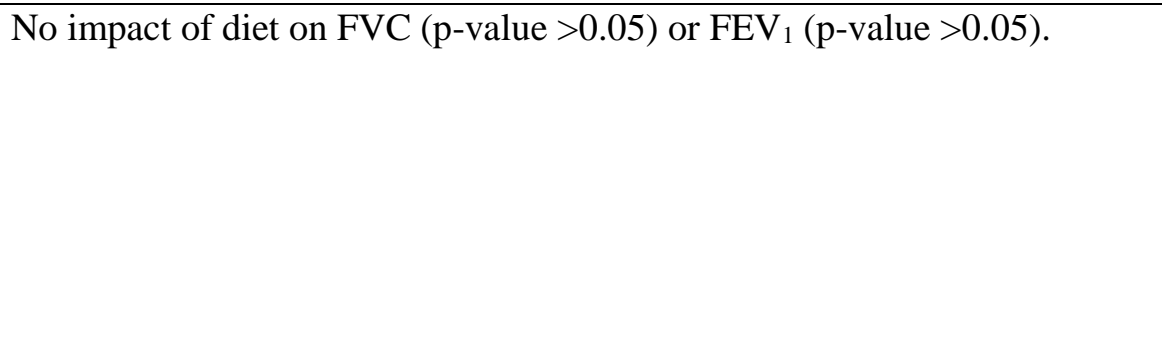 \\
\hline $\begin{array}{l}\text { Martin, M R } \\
(81) \\
2014 \\
\text { USA }\end{array}$ & $\begin{array}{l}\text { Cross- } \\
\text { sectional }\end{array}$ & $\begin{array}{l}\text { Adults } 45-64 \\
\text { years }(\mathrm{n}=15,567)\end{array}$ & $\begin{array}{l}\text { Modified semi- } \\
\text { quantitative food } \\
\text { frequency questionnaire. } \\
\text { Nutrient composition was } \\
\text { calculated based on the } \\
\text { dietary information. }\end{array}$ & $\begin{array}{l}\text { Higher intake of whole grains was associated with higher } \mathrm{FEV}_{1} / \mathrm{FVC} \\
\text { ratio, while saturated and solid fats were associated with lower } \mathrm{FEV}_{1} / \mathrm{FVC} \\
\text { ratio. }\end{array}$ \\
\hline $\begin{array}{l}\text { Bentley, AR } \\
(82) \\
2012 \\
\text { USA }\end{array}$ & $\begin{array}{l}\text { Prospective } \\
\text { cohort }\end{array}$ & $\begin{array}{l}70-79 \text { years old } \\
\text { Community- } \\
\text { dwelling older } \\
\text { adults ( }=3,075) \\
\text { History of } \\
\text { smoking } \\
\text { No history of } \\
\text { prevalent lung } \\
\text { disease (asthma } \\
\text { or COPD). }\end{array}$ & $\begin{array}{l}\text { Dietary antioxidant } \\
\text { (Vitamin C and } \mathrm{E} \text {, and } \beta \text { - } \\
\text { carotene) measured by } \\
\text { whole food intake and by } \\
\text { calculation of antioxidant } \\
\text { from all dietary sources }\end{array}$ & $\begin{array}{l}\text { Higher intake of antioxidant rich food (higher Vitamin } \mathrm{C} \text {, fruits, and } \\
\text { vegetables) associated with slower rate of declined } \mathrm{FEV}_{1} \text { (in current } \\
\text { smokers). } \\
\text { In continuing smokers, high intake of Vitamin } \mathrm{C} \text { or } \mathrm{E} \text { were associated } \\
\text { with slower rate of decline } \mathrm{FEV}_{1}(18 \text { and } 24 \mathrm{ml} / \mathrm{yr} \text {.) p-value }<0.001 \text { and } \\
<0.003 \text { respectively, while low intake of these nutrients had a higher rate } \\
\text { of decline } \mathrm{FEV}_{1} \text { ( } 43 \text { and } 42 \mathrm{ml} / \mathrm{yr} \text {.). Intake of } \beta \text {-carotene did not vary in } \\
\text { this association. } \\
\text { FEV } \\
\sim 2.5 \% \text { increased by } \sim 1-2 \% \text { in high consumption group and declined by } \\
\text { Little or no association was found in diet and rate of decline } \mathrm{FEV}_{1} \text {. } \\
\text { Results of } \mathrm{FVC} \text { were less consistent than } \mathrm{FEV}_{1} \text {. }\end{array}$ \\
\hline
\end{tabular}




\begin{tabular}{|c|c|c|c|c|}
\hline $\begin{array}{l}\text { Hirayama, F } \\
(83) \\
2010 \\
\text { Japan }\end{array}$ & Case-control & $\begin{array}{l}\text { Case: } \\
278 \text { referred } \\
\text { patients (men= } \\
\text { 244, women= 34) } \\
\text { Adults 50-75 } \\
\text { years. } \\
\text { Diagnosed with } \\
\text { COPD (within the } \\
\text { past } 4 \text { years). } \\
\text { Control: } \\
340 \text { community } \\
\text { based controls } \\
\text { (men=272, } \\
\text { women= 68), } \\
\text { Assessed for } \\
\text { dyspnea and have } \\
\text { spirometric } \\
\text { measurements }\end{array}$ & $\begin{array}{l}\text { Frequency of food by } \\
\text { using } 138 \text {-item food } \\
\text { frequency questionnaire } \\
\text { classified by nine } \\
\text { categories. The categories } \\
\text { were ranging from } \\
\text { "almost never" to "seven } \\
\text { or more times per day" }\end{array}$ & $\begin{array}{l}\text { Higher folate intake was associated with higher } \mathrm{FEV}_{1}(\beta=1.02,95 \% \mathrm{CI} \\
0.35-1.70) \text { and FVC }(\beta=0.84,95 \% \mathrm{CI} 0.13-1.55) \text {. } \\
\text { Higher intake of daily folate associated with decrease prevalence of } \\
\text { COPD. } \\
\text { Lower intake of folate associated with breathlessness (p-value }<0.001) \text {. }\end{array}$ \\
\hline $\begin{array}{l}\text { Jiang, R } \\
(84) \\
2007 \\
\text { USA }\end{array}$ & $\begin{array}{l}\text { Cross- } \\
\text { sectional }\end{array}$ & $\begin{array}{l}\text { Adults } \geq 45 \text { years } \\
\text { (n=7,352), } \\
\text { Excluded persons } \\
\text { with missing } \\
\text { values of cured } \\
\text { meat, fish, fruits } \\
\text { or vegetable } \\
\text { consumption, } \\
\text { Also, excluded } \\
\text { persons without } \\
\text { acceptable } \\
\text { spirometry } \\
\text { curves. }\end{array}$ & $\begin{array}{l}\text { Cured meat consumption: } \\
\text { The total onsumption of } \\
\text { bacon, sausage, and } \\
\text { luncheon meats. } \\
\text { Food frequency } \\
\text { questionnaire was used } \\
\text { including frequency of } \\
\text { consuming meats, fish, } \\
\text { fruits, and vegetables over } \\
\text { the past month. }\end{array}$ & $\begin{array}{l}\text { Higher consumption of cured meat was associated with lower } \mathrm{FEV}_{1}, \mathrm{FVC} \text {, } \\
\text { and } \mathrm{FEV}_{1} / \mathrm{FVC} \text { after adjusting demographics and height. } \\
\text { Consumption of cured meat } 14 \text { times or more per month was associated } \\
\text { with decreased } \mathrm{FEV}_{1}(-110 \mathrm{ml}, \mathrm{p} \text {-value }=<0.001) \text { and } \mathrm{FEV} / \mathrm{FVC}(-2.13 \% \text {, } \\
\text { p-value }=<0.001) \text { compared to those who never consumed cured meats. } \\
\text { Increased each time of cured meat intake per month was associated with } \\
\text { decreased } \mathrm{FEV}_{1}(3.85 \mathrm{ml}) \text { and decreased } \mathrm{FEV} / \mathrm{FVC}(-0.07 \%) \text {. } \\
\text { FVC did not vary significantly through the different categories of cured } \\
\text { meat. }\end{array}$ \\
\hline
\end{tabular}




\begin{tabular}{lll}
\hline Butland, BK & Prospective & Men aged 45-59 \\
$(85)$ & cohort study & years $(\mathrm{n}=2,512)$ \\
2000 & & living in \\
UK & & Caerphilly
\end{tabular}

Semi quantitative food frequency questionnaire was used for dietary information included frequency of intake (number of times/week in phase I and number of times/day in phase II). The quantity of intake was asked for some type of foods including a number (bread, eggs), size (bread, milk, butter/margarine), and portions (meat, fish).

Adults $>17$ years old $(\mathrm{n}=18,162)$ With spirometry results and dietary data

Cross-
sectional

USA

Carey, IM

(87)

1998

Prospective
cohort

UK

Caucasians 18-73 years with satisfactory spirometric

\section{Dietary antioxidant}

(Vitamin C, Vitamin E, $\beta$ carotene, and selenium)

intake and serum biomarkers stratified by smoking status
Multiple regression models were fitted to find out the association between dietary factors (exposure) and maximum $\mathrm{FEV}_{1}$ (outcome). In the crosssectional analysis, the maximum $\mathrm{FEV}_{1}$ was associated with higher Vitamin C, Vitamin E, and $\beta$-carotene (p-value < 0.001, 0.0009, and 0.031 respectively) which is reduced when unconfounded by BMI and lost significance when the model was adjusted for smoking and social class. A significant negative association was found between magnesium and total energy intake and lung function while a positive association was observed with frequent consumption of citrus fruit, fruit juices/squashes, and apples. After adjusting for smoking, BMI, social class, exercise, and total energy intake, only apple consumption remained statistically significant. No statistically significant association was found between the frequency of fatty fish intake and lung function. In the longitudinal analysis, no statistically significant association was found between the total number of apples per week, Vitamin $\mathrm{E}$, and Vitamin $\mathrm{C}$ and change in lung function between phase I and II.

Serum antioxidant was associated with lung function $\left(\mathrm{FEV}_{1}\right)$ independently. Joint effect of dietary antioxidant was higher than the single nutrient, but the only carotene was statistically significant. Dietary consumption of Vitamin C, Vitamin E, and carotene was highly correlated.

When stratified by smoking status:

Serum Vitamin E and $\mathrm{FEV}_{1}$ was weakly associated in former smokers (pvalue $=0.01$ ), while $\beta$-carotene was more weakly associated ( $p$ value $=0.03$ ), and selenium was strongly associated ( $\mathrm{p}$-value $=0.01)$ in a current smoker group than a non-smoker and former smoker group. measurements in both examinations $(\mathrm{n}=2,171)$
30 different items of fresh fruits (summer and winter), salads or raw vegetables (summer and winter), and pure fruit juice. For each food item, a consumption score was used (from 5 to 0
A person who consumed an average level of fresh fruit was not significant in changing $\mathrm{FEV}_{1}(\mathrm{p}$-value $=0.446)$, compare to a person who consumed a decreased level of fresh fruit. This was observed in all healthy individuals (overall $p$-value $=0.002)$, in female $(p$-value $<0.001)$ and in current smokers ( $\mathrm{p}$-value $=0.013$ ).

In comparing the cohort prospectively,

Individuals who did not change fruit intake in 7 years, $\mathrm{FEV}_{1}$ was alike and little variation with the level of fruit intake. 


\begin{tabular}{|c|c|c|c|c|}
\hline & & & $\begin{array}{l}\text { accordingly): }>1 \text { per day, } \\
\text { one per day, most days, } \\
\text { once or twice a week, less } \\
\text { than once a week, or } \\
\text { never. }\end{array}$ & $\begin{array}{l}\text { Individuals who reduced their fruit consumption in } 7 \text { years, showed a } \\
\text { decreased } F E V_{1} \text {. } \\
\text { Individuals who increased their fruit consumption in } 7 \text { years, showed an } \\
\text { increased } \mathrm{FEV}_{1} \text {. }\end{array}$ \\
\hline $\begin{array}{l}\text { Schwartz, J } \\
(88) \\
1994 \\
\text { USA }\end{array}$ & $\begin{array}{l}\text { Cross- } \\
\text { sectional }\end{array}$ & $\begin{array}{l}\text { Adults aged }(\geq 30 \text { - } \\
70) \text { years } \\
(\mathrm{n}=2,526) \\
\text { Excluded: } \\
\text { pregnant, acute or } \\
\text { chronic medical } \\
\text { conditions, and } \\
\text { inappropriate } \\
\text { spirometry } \\
\text { maneuver }\end{array}$ & $\begin{array}{l}\text { Usual consumption of fish } \\
\text { in the past three months. } \\
\text { Consumption of fish was } \\
\text { coded as portions per } \\
\text { week. }\end{array}$ & 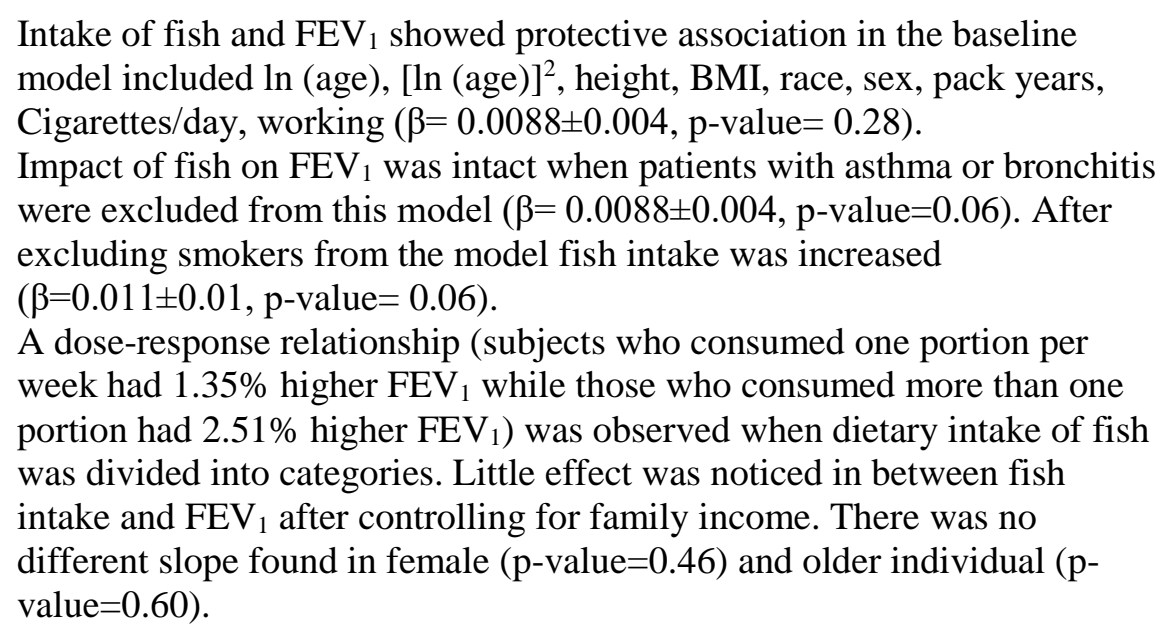 \\
\hline
\end{tabular}


It can be seen from Table 2.1 that these studies were conducted outside of Canada (in the USA, Poland, Japan, UK, and Spain) with the exception of Niruban, SJ et al (2015) (79). Crosssectional methods were used in the majority of the studies $(27,78,79,81,84,86,88)$. The other methods of study designs were prospective cohort $(82,85,87)$, case-control $(83)$, and analysis of medical documents (80). Considerable variability is observed among the study population as well. Some researchers included a wide range of ages (aged 13-69, >17, and 18-73 years respectively) $(79,86,87)$ whereas others included a smaller age range of adults (aged 35-70, 40-79, 45-64, $\geq 65$, $70-79,50-75, \geq 45,45-59$, and $\geq 30-70$ years respectively) $(27,78,80-85,88)$. As such, most of the studies included adults with a limited range of ages.

The exposure of interest varied between these studies from the use of a single nutrient (Vitamin D or dietary fiber) to multiple nutrients (Vitamin A, C, and E) and different food categories (e.g. meat, fish, and fruits). Only one of the studies included both nutritional biomarkers and various types of food categories obtained from food frequency questionnaire (86). The remaining studies used either serum biomarker (79) or food frequency questionnaire for dietary information as a measure of exposure $(27,78,80-85,87,88)$.

Over several years, reduced consumption of fresh fruits has been associated with changing lung function where increased fruit consumption was associated with improved lung function (87). Also, frequent consumption of cured meat has been associated with lower $\mathrm{FEV}_{1}$ and $\mathrm{FEV}_{1} / \mathrm{FVC}$ (84). Reduced consumption of dietary fiber was associated with lower lung function (27). A significant positive association has been observed between serum Vitamin $\mathrm{D}$ and $\mathrm{FEV}_{1} / \mathrm{FVC}$ in adults including older adults (79). A higher intake of antioxidants and fruits have also been found to be associated with the slower decline of $\mathrm{FEV}_{1}(82,85,86)$ suggesting that antioxidants can play an important role in slowing the decline of $\mathrm{FEV}_{1}$ in this population. Dietary intake of folate has 
been associated with higher $\mathrm{FEV}_{1}$ and FVC (83). Also, higher consumption of fish has shown a positive dose-response relationship with $\mathrm{FEV}_{1}(88)$.

Although not entirely consistent (80), various studies have indicated that dietary exposure has an influence on lung function $(87,84,27,79,82,85,86,83,88,78,81)$. The Wroblewska et al. study (80) was a hospital based study and included only an older population ( $\geq 65$ years), it cannot be generalised to the total population.

\subsection{Dietary types and lung function}

\subsubsection{Canada Food Guide}

The Canada Food Guide (CFG) is a dietary guide for Canadians produced by Health Canada (89). The first CFG was first introduced in 1942 to prevent nutritional deficiency and to improve the health of Canadians (89). This food guide has been transformed several times and updated including the most recent in 2007 to reach today's look of "Eating Well with Canada's Food Guide" (89). The CFG is a government produced and sponsored guideline for eating the right food group among the specified age group and gender with the main purpose to identify and promote a healthy dietary pattern to reduce the risk of nutrition related diseases (e.g. obesity, Cardiovascular disease) (89). Therefore, it is important to investigate the impact of the CFG on the Canadian population. Based on a person's age and sex, the actual food consumed can be compared to CFG to determine if the person meets or does not meet the suggested criteria. This assessment of the association between the Canada Food Guide and lung function or respiratory diseases has not previously been completed.

\subsubsection{Mediterranean Diet}

The Mediterranean Diet is a unique dietary pattern of the people living in the Mediterranean region which has previously shown to be able to improve asthma and lung function and has also 
been shown to beneficial with regard to other diseases (90). The Mediterranean Diet is composed of large quantities of fresh fruits, vegetables, legumes, nuts, whole grains, and olive oil; moderate to high quantities of fish; moderate quantities of dairy products (mostly cheese and yogurt); and low quantities of meat, poultry, and $\omega=6$ fatty acids (91). A modified Mediterranean Diet Score was established by Garcia-Marcos et al. (2007) (92) based on Psaltopoulou et al.(93). In this modified Mediterranean Diet Score, fish, fruits, vegetables, pulses, cereals, pasta, rice, and potatoes were considered as "pro-Mediterranean" food rated as 0,1 , or 2 points ranging from less frequent to more frequent consumption while milk, meat, and fast-food was considered as "antiMediterranean" food rated as 0,1 , or 2 ranging from more frequent to less frequent consumption (92).

\subsection{Biological mechanism of diet on lung function}

Oxidative stress produced by reactive oxygen species (ROS) can be generated in the lungs in response to several triggers including air pollution, irritants inhalation (smoking), and response by the inflammatory cells (94). Fat soluble antioxidants (Vitamin E, carotenoids ( $\alpha$ - and $\beta$ carotene, lycopene, lutein and $\beta$-cryptoxanthin) also act as scavengers to remove ROS and decrease oxidative stress $(95,96)$. Antioxidants (Vitamin C, Vitamin E, carotenoid, and flavonoid) are found in high quantities in fruits and vegetables (broccoli, spinach, tomatoes, citrus fruits, beans, and mangoes), mayonnaise, vegetable and seed oil, butter, eggs, nuts, cocoa, and green tea $(95,96)$. Another antioxidant, Lycopene (carotenoid) is predominantly present in tomatoes and shown to improve lung health (higher $\mathrm{FEV}_{1}$ ) by eliminating ROS and suppress airway inflammation $(95,96)$.

Vitamin D can be found from dietary sources and supplementation although the main source of Vitamin D is from sun exposure (97). Vitamin D protects the airway by reducing the susceptibility and severity of the respiratory infections (98). 
Minerals have also been found to protect against respiratory conditions. Inverse associations were observed between the increased intake of minerals (magnesium, calcium, potassium) and asthma prevalence (99).

\subsection{Inflammation and lung function}

Airway inflammation is a feature of lung diseases, especially in asthma and COPD $(39,44)$. Although the mechanism of the inflammatory process (e.g. type of inflammation, inflammatory cells, mediators, consequences of inflammation), etiology, and symptoms are dissimilar for different lung diseases (e.g. asthma, COPD) $(100,101)$, inflammation affects the airway and causes airway limitation and breathlessness (102-104). Airway limitation and breathlessness caused by inflammation may contribute to reducing the lung function (102-104).

\subsection{Biomarkers and their relationship to lung function}

Biomarkers are objective measurements whose presence is indicative of some phenomenon such as disease, infection, or environmental exposures. Biomarkers are used to represent dietary or nutrient intake (105). Various biomarkers can be used to explain nutritional status e.g. nutrient, food component, and an indicator of the development of diseases (106).

A significant association was found between higher serum folate and decreased risk of reduced lung function $\left(\mathrm{FEV}_{1} /\right.$ expected $\left.\mathrm{FEV}_{1}<80 \%\right)$ (107) while low dietary consumption of folate was significantly associated with reduced lung function (107). Serum folate and Vitamin B12 (cobalamin) may be associated with asthma and atopy. Decreased serum atopy was associated with atopy, elevated total IgE levels, and wheezing (108). A population based prospective cohort study (January 2001 to April 2006) was conducted in Denmark among adults aged 30-60 years to obtain in depth knowledge about the role of folate and Vitamin B 12 in atopic diseases showed that higher level of serum folate was associated with self-reported doctor diagnosed asthma and lower airway 
symptoms (107). A cross-sectional survey was conducted in 2005 among the US adults ( $\geq 20$ years) to determine the association between serum concentration of 25-hydroxy Vitamin D and pulmonary function with a dose-response relationship observed between Vitamin D and FEV 1 (109).

C-reactive protein (CRP) is a blood test marker which is produced in the liver in response to inflammation in the body (110). The level of CRP increases if there is systemic inflammation in the body due to infections or other medical conditions (110). In chronic lung diseases (e.g. asthma, COPD), colonization of lung by bacteria, smoking, obesity, and air pollution may stimulate the CRP production by producing more interleukine-6 $(102,111)$. The damaged lung tissue may itself act as a source for triggering synthesis for CRP as well (111). The Mediterranean dietary pattern is made up of anti-inflammatory components (e.g. fresh fruits, vegetables, fish, whole grains) which deliver omega-3 fatty acids. These foods, therefore, contain anti-inflammatory properties which reduces the inflammation and CRP (90). It is important to consider CRP since it may be associated with dietary patterns and may have an impact on aspects of lung disease including lung function.

\subsection{Potential for effect modification}

Based on previous studies, diet has been associated with asthma (112-121) and COPD $(22,69-74)$. There are several plausible biological mechanisms that exist to explain the effects of diet on asthma such as antioxidants protecting the airways by reducing airway inflammation from oxidants from both exogenous and endogenous sources (122). Endogenous sources include activated inflammatory cells and exogenous sources include smoking as an example (122). Foods

rich in antioxidants (Vitamin A, C, and E) are fruits, vegetables, and whole grain products. Consumption of fish oils (specifically, n-3 polyunsaturated fatty acids, eicosapentaenoic acids, and 
docosahexaenoic acid) are the precursor for the production of pro-inflammatory mediators (eicosanoids include prostaglandins and leukotrienes). Higher intake of n-3 fatty acids moves the balance towards the eicosanoids which are less active biologically (123). The lack of fish oils in westernized diets may promote airway inflammation and contribute to asthma. In COPD, antioxidants from food may protect the lung from oxidative damages and prevent air pollution induced oxidative stress (96). Also, a higher intake of fruits and vegetables may improve the lung function and decrease the COPD risk (72), (23).

No previous studies had investigated the interaction between diet and comorbidity of asthma and COPD. Because diet does have the potential to be associated with lung disease and lung function results can vary by the presence of these diseases. It is possible that effect modification between dietary factors and asthma or COPD may exist.

\subsection{Summary of literature review}

Respiratory diseases are associated with a large and increasing burden of morbidity and mortality globally. Lung function is an important assessment tool for respiratory disease and can be independently associated with a number of personal and environmental factors. Given the importance of spirometry and that many conditions may be associated with dietary factors, further research should be conducted to investigate the association between diet and lung function. 


\section{Chapter 3 : Methods}

\subsection{Data sources}

The data used for this thesis was from the Canadian Health Measures Survey (CHMS) (124-126). The CHMS is a national health study in Canada. It is led by Statistics Canada in partnership with Health Canada and the Public Health Agency of Canada. It is a repeated crosssectional study using both questionnaire report and clinical measures. Cycles 1 to 3 of the CHMS have been used for this thesis.

\subsection{Target population}

The target population for the CHMS was children, adolescents, and adults ( 6 to 79 years in Cycle 1 and 3 to 79 years in Cycles 2 \& 3). The data collection took place for Cycle 1 between March 2007 and February 2009, for Cycle 2 between August 2009 and November 2011, and for Cycle 3 between January 2012 and December 2013. The representative survey coverage excluded $4 \%$ of the population who were living in the three territories, Aboriginal reserves, full time members of the Canadian Forces, institutionalised populations, and residents living in remote regions. The data related to the adult component of the survey (ages 18 to 79 years) is the focus of this thesis. The reason for excluding children is the pattern of lung function development varies in younger age (children and adolescents) compared to adults. Also, it is more difficult to obtain accurate lung function results by spirometry among younger children. Furthermore, dietary requirements will vary in children and adolescent age group and their growth.

\subsection{Study design and sampling procedure}

A cross-sectional multi-stage survey design was used for the Canadian Health Measures Survey (CHMS). Each collection site was defined as a geographic area with the presence of a total population of at least 10,000. The Labour Force Survey (LFS) was used to create the collection 
site lists. The LFS used clusters which were small geographic units containing approximately 200 dwellings as a sampling frame. About 360 reporting units/sites per collection site were created by using LFS frame in Cycles 1 to 3. The reporting units (data collection area) were restricted to a radius (around the Mobile Examination Center located near the houses of collection sites) of about $50 \mathrm{~km}$ (up to $75 \mathrm{~km}$ for rural areas). To define the collection sites, geographic units were used, which were also grouped into provincial boundaries, census metropolitan-area boundaries, health regions and population density criteria.

The sites were sorted within each region according to their population size. They were first sorted by province within the Prairies and Atlantic regions. By using a systematic sampling method with a probability proportional to the size of each site's population, the sites were randomly selected. In the survey, approximately 5,700 participants across all the sites contributed data and represented approximately $96 \%$ of the Canadian population.

The 2011 census was used as a frame within each of the 16 Cycle 3 selected collection sites. To improve the coverage, new dwellings from Statistics Canada's address register were used as well. Using the census time date of birth and more current information from other administrative sources, the people living in the dwellings were stratified into six age groups. The samples were allocated in such a manner that each stratum obtained target numbers of respondents by age group.

\subsection{Methods of data collection (CHMS)}

The CHMS collects health information and direct physical measurements such as blood pressure, height, weight, physical fitness, and biomonitoring components (e. g. blood samples) of Canadians. At the beginning of this analysis for the thesis, three Cycles had been completed and used. These are repeated cross-sectional studies that have independent participants. The CHMS 
collected data from multiple collection sites stratified in 5 regions. The regions were Atlantic, Quebec, Ontario, Prairies (Alberta and Manitoba), and British Columbia.

Cycle 1 (2007-2009): Cycle 1 included approximately 5,604 Canadians at 15 collection sites throughout the country. The collection sites were: Atlantic-1, Quebec-4, Ontario-6, Prairies-2, and British Columbia-2. The adult sample included 3726 people which represented 24,531,089 Canadians.

Cycle 2 (2009-2011): Cycle 2 included approximately 6,395 Canadians at 18 collection sites throughout the country. The collection sites were: Atlantic-2, Quebec-4, Ontario-6, Prairies-3, and British Columbia-3. The adult sample included 3873 people which represented 25,327,408 Canadians.

Cycle 3 (2012-2013): Cycle 3 included approximately 5,785 Canadians at 16 collection sites throughout the country. The collection sites were: Atlantic-2, Quebec-4, Ontario-6, Prairies-2, and British Columbia-2. The adult sample included 3397 people which represented 25,974,338 Canadians.

The methods of data collection for all three Cycles are similar except for variations with collection sites and age ranges. Cycle 1 had 15 collection sites with an age range of 6-79 years, whereas Cycle 2 had 18 collection sites with an age range of 3-79 years, and Cycle 3 had 16 collection sites with an age range of 3-79 years. The spirometry measurements were collected from age 6 years and above in all three data collection Cycles.

For the adult population, information was collected directly from the respondents and was voluntary. The collection included a computer assisted personal interview (CAPI) followed by a 
physical assessment. The physical measures were completed at Mobile Examination Centers specifically designed for the survey.

The CHMS Mobile Examination Centers stayed in each site for five to seven weeks gathering direct measures from the respondents. Several steps were followed during data collection. The data collection steps were as follows (124-126):

- A letter was sent by mail as the first contact. The letter was written to inform the potential participant about the survey and stated that an interviewer would visit their home for data collection.

- The data collection then began with the personal interview at the household. At home, one or two respondents were selected randomly, and the interviewer conducted separate interviews with each person. The duration of the interview was about 45-60 minutes per respondent. The interviewer then helped the respondent set an appointment for the physical measures at the CHMS Mobile Examination Centers.

- The next step was to visit the CHMS Mobile Examination Centers. The Mobile Examination Centers consisted of two trailers linked by an enclosed pedestrian walkway. One trailer served as a reception and administration area and the other worked as a physical measures room and laboratory. For each respondent, the duration of the CHMS Mobile Examination Centers visit was about two hours. The respondents were provided a waterproof activity monitor at the end of their visit. This small device was for recording information regarding their physical activity patterns.

\subsection{Analytical framework}

The framework below (Figure 1) illustrates that evaluation needs to assess the association between dietary factors and lung function. In the box on the left, the dietary factors and biomarkers 
were the primary exposures of interest in this study. In the top middle box, demographic characteristics, co-morbidity, and environmental factors were potential confounders and considered as covariates. In the middle lower box, interaction terms for diet and asthma and diet and COPD were considered. In the box on the right, lung function was the outcome variable of interest.

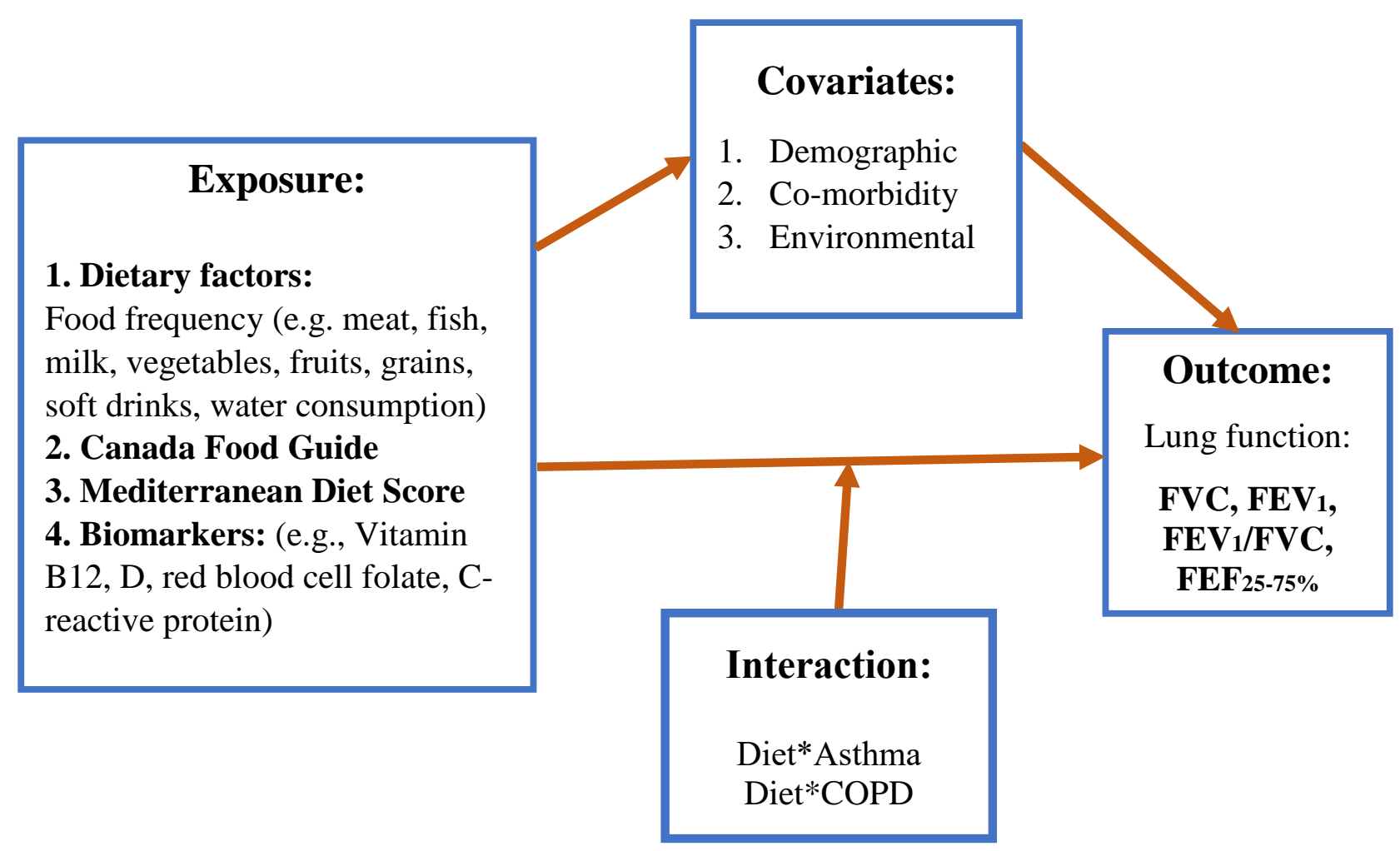

Figure 3.1 Analytical framework for dietary factors and lung function 


\subsection{Operational definitions}

1) $\mathrm{FEV}_{1}$ : Forced Expiratory Volume in the $1^{\text {st }}$ second. This is the volume $(\mathrm{L})$ of air expired in the first second during the maximal expiratory effort. The largest $\mathrm{FEV}_{1}$ from the acceptable trials was used for analysis.

2) FVC: Forced Vital Capacity. This is the total volume (L) of air expired after a full inspiration during a forced expiratory maneuver. The largest FVC from the acceptable trials was used for analysis.

3) $\mathrm{FEV}_{1} / \mathrm{FVC}$ : This is the percentage of the forced vital capacity that is expired in the first second of maximal expiration.

4) $\mathrm{FEF}_{25-75 \%}$ : This is the average flow expired during the middle half of the FVC collected from acceptable trials \& largest sum of $\mathrm{FVC}+\mathrm{FEV}_{1}$

5) Ever asthma: Presence of long term asthma expected to last or already have lasted for six months or more than that and have been diagnosed by a health professional. It is based on the question: "Do you have asthma? Yes/No which came after the following preamble: "Now I'd like to ask about certain chronic health conditions which you may have." (Household questionnaire, Statistics Canada). Current asthma was assessed from the household questionnaire, "Have you had any asthma symptoms or asthma attacks in the past 12 months?" Answered as: yes or no.

6) Other respiratory diseases:

- COPD: "Do you have chronic obstructive pulmonary disease (COPD)?" Answered as: yes or no.

- Chronic bronchitis: "Do you have chronic bronchitis?” Answered as: yes or no.

- Emphysema: "Do you have emphysema?" Answered as: yes or no. 
7) Dietary factors: The frequency of consuming different amounts of meat, fish, fruits, vegetables, grains, milk and milk products, dietary fat, water and soft drinks consumption was measured. The specific items and questions to determine the type of foods eaten are located in Appendix 1. The question for each food category was: "How often do you usually eat...?" The answer categories for these questions were for example: twice a day, three times a week, once a month. The total number of times consuming the food was then calculated for the year (derived by Statistics Canada) then divided by 52 to calculate a weekly value. The dietary variables were divided into tertiles (low, medium, and high) based on Ye, M et al. (2015)(127).

8) Canada Food Guide: Dietary categories were developed based on the recommendation of Canada Food Guide serving requirements. Four variables based on categories of dietary factors were created: a) vegetables \& fruits, b) Grains, c) Milk and milk alternatives, and d) Meat and meat alternatives.

a) Vegetables and fruits: This variable included vegetables, fruits, and potatoes. Based on the Canada Food Guide, the following cut-offs were used to categorize meeting or not meeting the recommended guidelines.

For male age 51 years and above: 7 servings or more per day was recommended.

For male age below 51 years: 8 servings or more per day was recommended.

For female age 51 and above: 7 servings or more per day was recommended.

For female age below 51 years: 7 servings or more per day was recommended. 
b) Grains: This variable included cereal, bread, rice, and pasta. Based on the Canada Food Guide, the following cut-offs were used to categorize meeting or not meeting the recommended guidelines.

For male age 51 years and above: 7 servings or more per day was recommended. For male age below 51 years: 8 servings or more per day was recommended.

For female age 51 and above: 6 servings or more per day was recommended.

For female age below 51 years: 6 servings or more per day was recommended.

c) Milk and milk alternatives: This variable included milk, cottage cheese, yogurt, and ice cream and frozen yogurt. Based on the Canada Food Guide, the following cut-offs were used to categorize meeting or not meeting the recommended guidelines.

For male age 51 years and above: 3 servings or more per day was recommended.

For male age below 51 years: 2 servings or more per day was recommended.

For female age 51 and above: 3 servings or more per day was recommended.

For female age below 51 years: 2 servings or more per day was recommended.

d) Meat and meat alternatives: This variable included red meat, fish, eggs, and beans. Based on the Canada Food Guide, the following cut-offs were used to categorize meeting or not meeting the recommended guidelines.

For male age 51 years and above: 3 servings or more per day was recommended.

For male age below 51 years: 3 servings or more per day was recommended.

For female age 51 and above: 2 servings or more per day was recommended.

For female age below 51 years: 2 servings or more per day was recommended.

9) Mediterranean Diet Score: A modified Mediterranean Diet Score was used based on the article by Garcia-Marcos (92). In the original computation of the Mediterranean Diet Score 
the variables used in its calculation were based on the following categories: a) never, b) 12 times per week, and c) 3 times or more per week. Based on these categories, the dietary factors considered as protective (fish, vegetables, fruits, cereal, pasta, rice, and potato) were assigned the highest score (score 2 ) for consuming 3 times or more per week. The dietary factors considered as not protective (meat, milk) based on the above scoring were assigned the lowest score (score 0 ) for consuming 3 times or more per week. All dietary factors were assigned a middle score (score 1 ) for consuming 1 to 2 times per week. Each type of score was summed to get a total score for a person. In the past, Psaltopoulou et al. (93) and Trichopoulou et al. (91) used Mediterranean Diet Scoring which included monounsaturated lipid (mainly olive oil), polyunsaturated lipids (vegetable-seed oils), saturated lipids, and ethanol intake. However, we did not have these information available, which is the reason for our modified score.

\subsection{Co-variates}

Variables used for the statistical analysis were determined directly from the survey questionnaire and clinical testing. The variables that were used as co-variates included: age (continuous), sex (male/female), height (continuous), race (Caucasian/other), BMI (obese/overweight/not overweight or obese), immigration status (yes/no), marital status (married, common-law/widowed, separated, divorced, single), educational status (less than secondary school graduation/secondary school graduation/some post-secondary/post-secondary), income $(\mathrm{CAD}<30,000 / 30,000-<50,000 / 50,000-<80,000 / \geq 80,000)$, smoking (never/occasional/ daily), smoking exposure (never/occasional/ everyday), alcohol drinker (never/former/occasional/ regular), current asthma (yes/no), family history of asthma (yes/no), other respiratory diseases (yes/no), total physical activities (continuous), and sedentary activity (continuous). The variables 
were chosen based on previous studies $(49,62,50-52,56,57,65,66)$. See details description of covariates in Appendix 1.

\subsection{Data collection}

\subsubsection{Questionnaires}

\section{a) Household questionnaire}

The household questionnaire was completed by in-person interviewing assisted by a computer. The household questionnaires were developed in such a way that there was logical flow into and out of the questions programmed. This method was comprised of specifying the type of answer needed, the minimum and maximum values along with what to do in non-response cases. The questions included were fully reviewed several times during development. The household questionnaire included information on socio-demographic characteristics, dietary factors, personal factors, and chronic conditions. The detailed description of the information collected from the questionnaires is located in Appendix 1.

\section{b) Clinic questionnaire}

The clinic questionnaires were completed by the participant during their visit to the CHMS Mobile Examination Centers to assess the eligibility for collecting physical measures (e.g. height, weight, spirometry, and so on) and bio-samples. The interview administered clinic questionnaires included different screening questions for laboratory analysis of biological specimens (these biological specimens are the indicators of general health, chronic disease, infectious disease, nutritional status and environmental biomarkers). 


\subsubsection{Health visits}

\section{a) Spirometry Procedures}

The most important aspects of spirometry are FVC (Forced Vital Capacity) and FEV 1 (Forced Expiratory Volume in $1^{\text {st }}$ second). Spirometry measurement was taken from all the eligible participants by following the 1994 update of the standardization of spirometry article by the American Thoracic Society (ATS) (28).

Forced expiratory manoeuvres were used to measure the lung function values of interest. In sitting position, the participant was asked by a coach to take the deepest breath in and then exhale into the spirometer as hard as possible. The maneouver was expected to last at least 6 seconds. In the maneuver, a soft nose clip was used to prevent air escaping through the nose.

\section{b) Objective lab measures}

Specific participants were selected for zero (if not eligible for a specific sample), one, two or three laboratories samples. The laboratory technician performed specimen collection (blood and urine). Both fasting and random blood samples were collected independently. The complete blood count (CBC) analysis was conducted. After that, biological samples for storage and shipment to the reference laboratories were processed for further analysis. For the biomarker assessment, collected samples were analysed for:

In blood: Vitamin B12 and D, red blood cell folate, chloride, potassium, C-reactive protein, high density lipoprotein (HDL), total cholesterol, total protein, sodium, and calcium.

\subsection{Statistical Analyses}

The statistical analysis was completed using SAS 9.4 and STATA 14 statistical software. Weighting variables for population sampling weights and boot-strapping for variance were used 
in the analysis. These were supplied by Statistics Canada. Bootstrapping is a method that depends on random sampling with a replacement. It allows assigning measures of accuracy (bias, variance, confidence intervals, prediction error or some other such measure) to sample estimates (128). The data was checked by using basic descriptive statistics. Means and standard deviations were used for continuous variables, while frequencies and proportions were used for categorical variables.

\subsubsection{Analysis for research question 1 (What are the characteristics/status of lung function

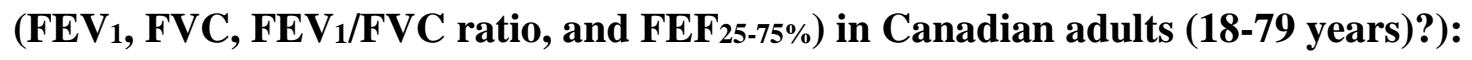

The outcome was lung function status as described above. A descriptive analysis was performed for research question 1. Means and standard deviations were used for continuous variables, while frequencies and proportions were used for categorical variables. Analysis of covariance was performed to compare absolute lung function by different variable categories after adjusting for age, sex, height, and ethnicity. See descriptive statistics by age group in Appendix 2. A separate descriptive analysis was also performed examining percent predicted lung function results. Percent predicted values were based on Hankinson's prediction equations (129) computed by Statistics Canada as per the equation below:

$$
\% \text { predicted }=(\text { measured } / \text { predicted }) X 100 .(129)
$$

3.9.2 Analysis for research question 2.A (Are dietary factors (e.g. food types), dietary patterns (e.g. Mediterranean Diet), or biomarkers associated with lung function levels based on spirometry in a nationally representative Canadian population of adults?):

Multiple linear regression models were fitted to investigate to what extent dietary factors were associated with lung function levels in Canada while controlling for the various confounders identified above. The main effects models including only the demographic variables for each outcome are located in Appendix 3.

Model building and variable selection: 
a) Univariate analysis: We performed a linear regression between each potential independent variable and lung function levels $\left(\mathrm{FEV}_{1}, \mathrm{FEV}, \mathrm{FEV}_{1} / \mathrm{FVC}\right.$, and $\left.\mathrm{FEF}_{25-75 \%}\right)$ while adjusting for age, sex, height, and ethnicity. Variables with a p-value $<0.25$ will be kept in the subsequent model.

b) Multivariate analysis: After univariate selection, multiple linear regression analysis was performed with eligible variables. In this stage, variables with a p-value $<0.05$ were kept in the model for further analysis.

c) Potential confounders: Based on previous literature, age, race, sex, BMI, family history, place of residence, socioeconomic status, conditions presence, physical activity, and smoking were considered as confounders $(79,130-134)$. We could not keep the place of residence in the analysis because including it in the model made the model unstable (bootstrapping variables could not replicate efficiently). For the assessment of the confounding effect of a variable, two multivariable models were fitted; one model did not include that particular variable and another model included that particular variable. Then a comparison between these two models was made, evaluating the changes in the beta coefficients of other variables. If the change was $>15 \%$ then confounding was considered present and it was kept in the model $(135,136)$.

Confounding $=\frac{\beta(\text { model with particular variable })-\beta(\text { model without particular variable })}{\beta(\text { model } \text { with } \text { particular variable })} \times 100$

$(135,136)$

\subsubsection{Analysis for research question 2.B (Is there effect modification between dietary factors and asthma or COPD in the relationship with lung function?):}

The potential effect modification between dietary variables and asthma/COPD was assessed to answer the Research Question 2B. A series of interaction terms (dietary variable*asthma) were fitted with the main effects model fitted for research question \#2 to test the significance of that 
interaction term. If the interaction term was statistically significant at $\alpha=0.05$, then the interaction was considered to be present.

\subsection{Ethical considerations}

To respect the privacy and maintain confidentiality, Statistics Canada is prohibited by law from discharging any information that could identify any person except when consent is provided by the participant or permitted by the Statistics Act. Statistics Canada has various rules to maintain the confidentiality of the respondent. One such method is to allow access to the data through approved Research Data Centres (RDC). At the University of Saskatchewan, this is the SKY-RDC. Access to the data is not allowed until the investigator undergoes a thorough screening procedure and being sworn in as a deemed employee of Statistics Canada. All result files were vetted prior to release from the RDC by an RDC analyst.

\subsection{Access to SKY-RDC}

Upon approval of the research pre-proposal by the committee of the Department of Community Health and Epidemiology, an application was submitted in conjunction with Dr. Joshua Lawson (Associate Professor, Canadian Center for Health and Safety in Agriculture) to the SKY-RDC for accessing the data of Canadian Health Measures Survey (CHMS), Statistics Canada. After receiving access to the data, analysis of this study began. 


\section{Chapter 4 : Results}

\subsection{Descriptive characteristics of the study population}

\subsubsection{Demographic and personal characteristics}

Table 4.1 shows the overall demographic, behavioral, and personal characteristics for the study population for three Cycles (Cycles 1,2, and 3) of the CHMS. The descriptive results were consistent throughout the Cycles except for sedentary activity in Cycle 1 (mean $188.48 \pm 2.81$ minutes/day) which was lower compared to the other Cycles (mean 493.80 \pm 4.83 mins/day and mean 502.55 \pm 4.92 mins/day for Cycle 2 and 3, respectively). Within educational status, secondary school graduation was more common in Cycle 3 (25.02\%) compared to Cycles 1 and 2 (18.76\% and $15.83 \%$ for Cycles 1 and 2 respectively). However, in the survey, there was no category for "some post-secondary education" in Cycle 3. Demographic characteristics by age group are located in Appendix 2. A 5\% difference in the observation can be considered as important (137). The following patterns were observed when comparing Cycles overall.

- The proportion of participants within "Caucasian" ethnicity gradually decreased from Cycle 1 to 3 .

- The proportion of participants within "never" exposure to second hand smoke gradually decreased from Cycle 1 to 3 .

- The mean values of sedentary activity were gradually increased from Cycle 1 to 3 . 
Table 4.1 Descriptive statistics (overall) of socio-demographic, behavioral, and personal characteristics represented in each of the Cycles

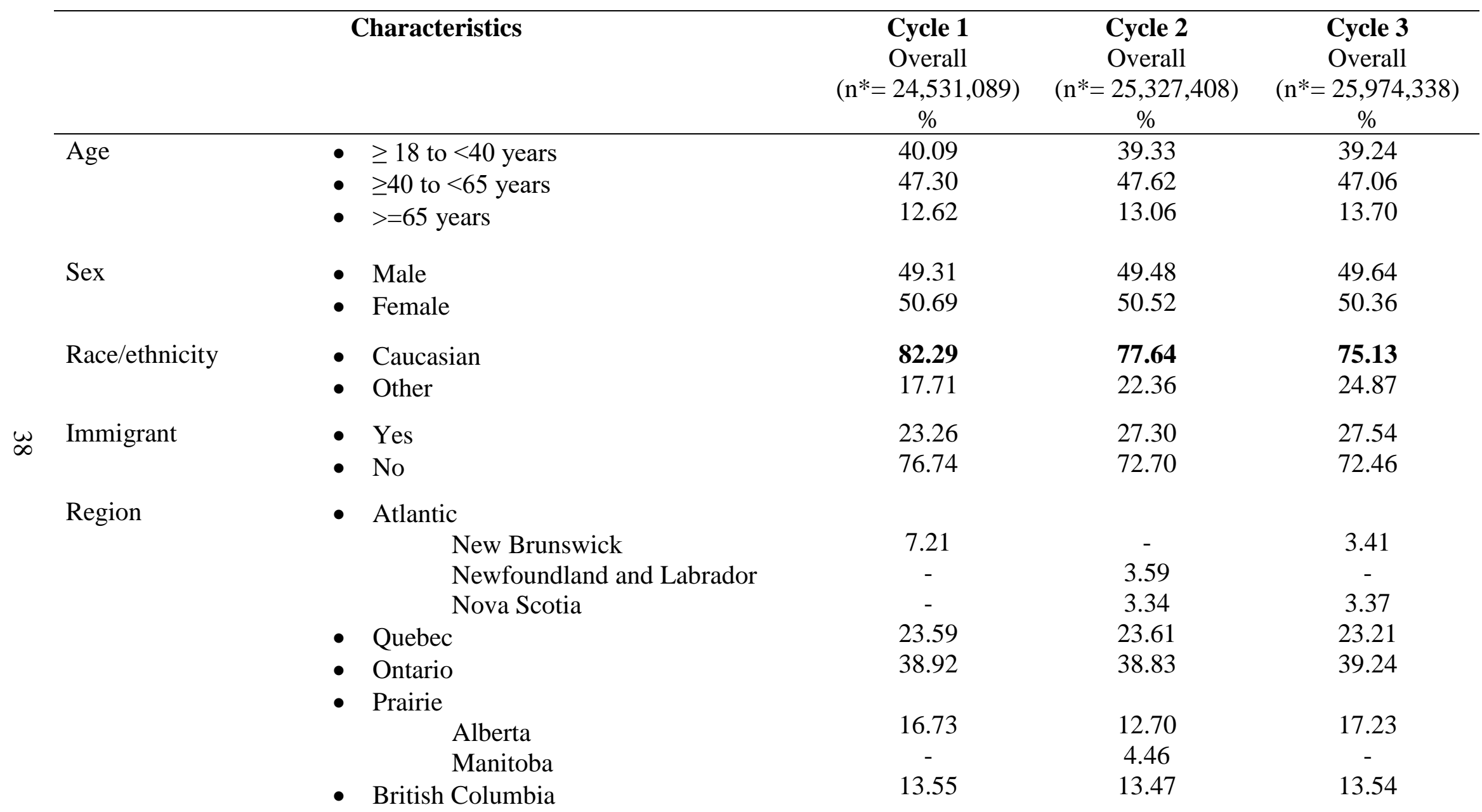




\begin{tabular}{|c|c|c|c|c|}
\hline Marital status & $\begin{array}{l}\text { - } \text { Married/ Common-law } \\
\text { - Widowed, Separated, Divorced, Single, } \\
\text { never married }\end{array}$ & $\begin{array}{l}66.18 \\
33.82\end{array}$ & $\begin{array}{l}63.95 \\
36.05\end{array}$ & $\begin{array}{l}62.93 \\
37.07\end{array}$ \\
\hline Educational status & $\begin{array}{l}\text { - Post-secondary graduation } \\
\text { - Some post-secondary } \\
\text { - Secondary school graduation } \\
\text { - Less than secondary school graduation }\end{array}$ & $\begin{array}{c}59.09 \\
9.42 \\
18.76 \\
12.73\end{array}$ & $\begin{array}{l}60.22 \\
10.50 \\
15.83 \\
13.45\end{array}$ & $\begin{array}{c}62.31 \\
- \\
25.02 \\
12.67\end{array}$ \\
\hline Family income & $\begin{array}{ll}\text { - } & \mathrm{CAD} \geq 80,000 \\
\text { - } & \mathrm{CAD} \geq 50,000 \text { to }<80,000 \\
\text { - } & \mathrm{CAD} \geq 30,000 \text { to }<50,000 \\
\text { - } & \mathrm{CAD}<30,000\end{array}$ & $\begin{array}{l}39.97 \\
25.86 \\
18.86 \\
15.31\end{array}$ & $\begin{array}{l}41.14 \\
24.97 \\
17.74 \\
16.15\end{array}$ & $\begin{array}{l}41.58 \\
23.02 \\
20.34 \\
15.06\end{array}$ \\
\hline Height & - Mean $(\mathrm{cm}) /$ Standard error (SE) & $168.62 \pm 0.27$ & $168.45 \pm 0.34$ & $168.91 \pm 0.40$ \\
\hline Weight & - Mean (kilogram) / Standard error (SE) & $77.35 \pm 0.72$ & $77.61 \pm 0.92$ & $78.35 \pm 1.16$ \\
\hline BMI & $\begin{array}{l}\text { - Obese } \\
\text { - Overweight } \\
\text { - Not overweight or obese }\end{array}$ & $\begin{array}{l}23.92 \\
36.72 \\
39.36\end{array}$ & $\begin{array}{l}26.23 \\
34.22 \\
39.55\end{array}$ & $\begin{array}{l}26.39 \\
35.60 \\
38.00\end{array}$ \\
\hline Smoking & $\begin{array}{l}\text { - Daily smoker } \\
\text { - Former smoker } \\
\text { - Never }\end{array}$ & $\begin{array}{l}21.71 \\
29.68 \\
48.62\end{array}$ & $\begin{array}{l}20.65 \\
28.73 \\
50.62\end{array}$ & $\begin{array}{l}22.92 \\
26.10 \\
50.97\end{array}$ \\
\hline $\begin{array}{l}\text { Exposure to } \\
\text { second hand } \\
\text { smoking }\end{array}$ & $\begin{array}{ll}\text { - } & \text { Every day } \\
\text { - Occasional } \\
\text { - }\end{array}$ & $\begin{array}{l}16.11 \\
36.51 \\
\mathbf{4 7 . 3 8}\end{array}$ & $\begin{array}{l}15.71 \\
38.81 \\
\mathbf{4 5 . 4 9}\end{array}$ & $\begin{array}{l}22.48 \\
37.59 \\
\mathbf{3 9 . 9 4}\end{array}$ \\
\hline
\end{tabular}




\begin{tabular}{|c|c|c|c|c|}
\hline Alcohol drinker & $\begin{array}{ll}\text { - } & \text { Regular drinker } \\
\text { - } & \text { Occasional drinker } \\
\text { - } & \text { Former drinker } \\
\text { - } & \text { Never drunk }\end{array}$ & $\begin{array}{l}68.69 \\
16.83 \\
8.92 \\
5.57\end{array}$ & $\begin{array}{c}67.11 \\
15.47 \\
10.53 \\
6.89\end{array}$ & $\begin{array}{l}69.68 \\
12.77 \\
9.91 \\
7.63\end{array}$ \\
\hline Ever asthma & $\begin{array}{l}\text { - } \mathrm{Yes} \\
\text { - } \mathrm{No}\end{array}$ & $\begin{array}{c}7.63 \\
92.37\end{array}$ & $\begin{array}{l}10.07 \\
89.93\end{array}$ & $\begin{array}{c}9.35 \\
90.65\end{array}$ \\
\hline Current asthma & $\begin{array}{l}\text { - } \quad \text { Yes } \\
\text { - } \quad \text { No }\end{array}$ & $\begin{array}{c}4.28 \\
95.72\end{array}$ & $\begin{array}{c}4.54 \\
95.46\end{array}$ & $\begin{array}{c}4.44 \\
95.56\end{array}$ \\
\hline $\begin{array}{l}\text { Obstructive lung } \\
\text { disease (Chronic } \\
\text { bronchitis, } \\
\text { Emphysema, } \\
\text { COPD) }\end{array}$ & $\begin{array}{ll}\text { - } & \text { Yes } \\
\text { - } & \text { No }\end{array}$ & $\begin{array}{c}3.24 \\
96.76\end{array}$ & $\begin{array}{c}4.22 \\
95.78\end{array}$ & $\begin{array}{c}2.98 \\
97.02\end{array}$ \\
\hline $\begin{array}{l}\text { Family history of } \\
\text { asthma }\end{array}$ & $\begin{array}{l}\text { - } \quad \text { Yes } \\
\text { - } \mathrm{No}\end{array}$ & $\begin{array}{l}22.23 \\
77.77\end{array}$ & $\begin{array}{l}23.65 \\
76.35\end{array}$ & $\begin{array}{l}21.98 \\
78.02\end{array}$ \\
\hline Sedentary activity & $\begin{array}{l}\text { - Mean (minutes/day) / Standard error } \\
\text { (SE) }\end{array}$ & $188.48 \pm 2.81$ & $493.80 \pm 4.83$ & $502.55 \pm 4.92$ \\
\hline
\end{tabular}




\subsubsection{Dietary factors}

Descriptive statistics of the dietary factors are presented by tertile in Table 4.2. Each of the Cycles had a consistent pattern of dietary consumption where there were minimal differences in the proportion of people (i.e. $<5 \%$ difference between Cycles) consuming the different amounts of food with the exception of the following: consuming egg, fruit, potato, dietary fat, and water. Below are the highlights of the differences between cycles while descriptive statistics of dietary factors by age group and by region/provinces are located in Appendix 2 .

- In Cycle 3, the proportion of participants in the middle tertile of egg consumption was higher (40.6\%) compared to Cycles 1 (26.8\%) and $2(24.6 \%)$ while the proportion of participants in the high tertile of egg consumption was lower in Cycle 3 (37.9\%) compared to Cycles 1 $(48.5 \%)$ and $2(54.4 \%)$.

- In Cycle 2, the proportion of participants in the middle tertile of fruit consumption was lower (4.5\%) compared to Cycles 1 (38.6\%) and $3(35.5 \%)$ while the proportion was higher for the high tertile (63.0\%) compared to Cycles $1(31.3 \%)$ and 3 (29.9).

- In Cycle 2, the proportion of participants in the low tertile of potato consumption was lower (30.0\%) compared to Cycles 1 (35.1\%) and $3(34.6 \%)$.

- In Cycle 3, the proportion of participants in the low tertile of dietary fat consumption was higher (37.0\%) compared to Cycles $1(33.1 \%)$ and $2(30.7 \%)$ while increased in the high tertile of dietary fat consumption in Cycle 2 (38.6\%) compared to Cycles $1(33.2 \%)$ and $3(31.6 \%)$.

- In Cycle 1, the proportion of participants in the low tertile of water consumption was higher (30.5\%) compared to Cycles 2 (25.0\%) and 3 (23.1\%) while the proportion of participants in the middle tertile of water consumption was lower (31.1\%) compared to Cycles $2(40.3 \%)$ and $3(40.7 \%)$. 
Table 4.2 Descriptive statistics of dietary factors (tertiles) represented in each of the Cycles

\begin{tabular}{|c|c|c|c|c|}
\hline Dietary factors & $\begin{array}{c}\text { Tertiles } \\
\text { Times/week }\end{array}$ & $\begin{array}{c}\text { Cycle 1 } \\
\left(\mathrm{n}^{*}=24,531,089\right) \\
\text { Overall } \\
\%\end{array}$ & $\begin{array}{c}\text { Cycle 2 } \\
(\mathrm{n} *=25,327,408) \\
\text { Overall } \\
\%\end{array}$ & $\begin{array}{c}\text { Cycle 3 } \\
(\mathrm{n} *=25,974,338) \\
\text { Overall } \\
\%\end{array}$ \\
\hline Red meat & $\begin{array}{ll}\text { - } & \text { Low } \\
\text { - } & \text { Medium } \\
\text { - } & \text { High }\end{array}$ & $\begin{array}{l}32.97 \\
31.55 \\
35.48\end{array}$ & $\begin{array}{l}32.42 \\
31.33 \\
36.25\end{array}$ & $\begin{array}{l}35.55 \\
32.05 \\
32.40\end{array}$ \\
\hline Fish and shellfish & $\begin{array}{ll}\text { - } & \text { Low } \\
\text { - } & \text { Medium } \\
\text { - } & \text { High }\end{array}$ & $\begin{array}{l}33.61 \\
31.11 \\
35.28\end{array}$ & $\begin{array}{l}31.01 \\
33.32 \\
35.66\end{array}$ & $\begin{array}{l}30.97 \\
34.42 \\
34.60\end{array}$ \\
\hline Eggs and eggs dishes & $\begin{array}{ll}\text { - } & \text { Low } \\
\text { - } & \text { Medium } \\
\text { - } & \text { High }\end{array}$ & $\begin{array}{l}24.67 \\
\mathbf{2 6 . 8 2} \\
\mathbf{4 8 . 5 1}\end{array}$ & $\begin{array}{l}20.98 \\
\mathbf{2 4 . 5 8} \\
\mathbf{5 4 . 4 3}\end{array}$ & $\begin{array}{l}21.41 \\
\mathbf{4 0 . 6 5} \\
\mathbf{3 7 . 9 3}\end{array}$ \\
\hline Beans and nuts & $\begin{array}{ll}\text { - } & \text { Low } \\
\text { - } & \text { Medium } \\
\text { - } & \text { High }\end{array}$ & $\begin{array}{l}31.36 \\
36.35 \\
32.30\end{array}$ & $\begin{array}{l}30.49 \\
32.80 \\
36.70\end{array}$ & $\begin{array}{l}33.31 \\
33.35 \\
33.34\end{array}$ \\
\hline Milk and dairy products & $\begin{array}{ll}\text { - } & \text { Low } \\
\text { - } & \text { Medium } \\
\text { - } & \text { High }\end{array}$ & $\begin{array}{l}33.89 \\
33.05 \\
33.05\end{array}$ & $\begin{array}{l}37.26 \\
32.14 \\
30.60\end{array}$ & $\begin{array}{l}35.19 \\
33.16 \\
31.65\end{array}$ \\
\hline Grains & $\begin{array}{ll}\text { - } & \text { Low } \\
\text { - } & \text { Medium } \\
\text { - } & \text { High }\end{array}$ & $\begin{array}{l}33.66 \\
32.83 \\
33.50\end{array}$ & $\begin{array}{l}33.07 \\
31.30 \\
35.63\end{array}$ & $\begin{array}{l}34.48 \\
35.48 \\
30.03\end{array}$ \\
\hline Fruits & $\begin{array}{ll}\text { - } & \text { Low } \\
\text { - } & \text { Medium } \\
\text { - } & \text { High } \\
\end{array}$ & $\begin{array}{l}30.04 \\
38.65 \\
\mathbf{3 1 . 3 1} \\
\end{array}$ & $\begin{array}{c}32.48 \\
\mathbf{4 . 4 8} \\
\mathbf{6 3 . 0 4} \\
\end{array}$ & $\begin{array}{l}34.57 \\
\mathbf{3 5 . 5 1} \\
\mathbf{2 9 . 9 3} \\
\end{array}$ \\
\hline
\end{tabular}




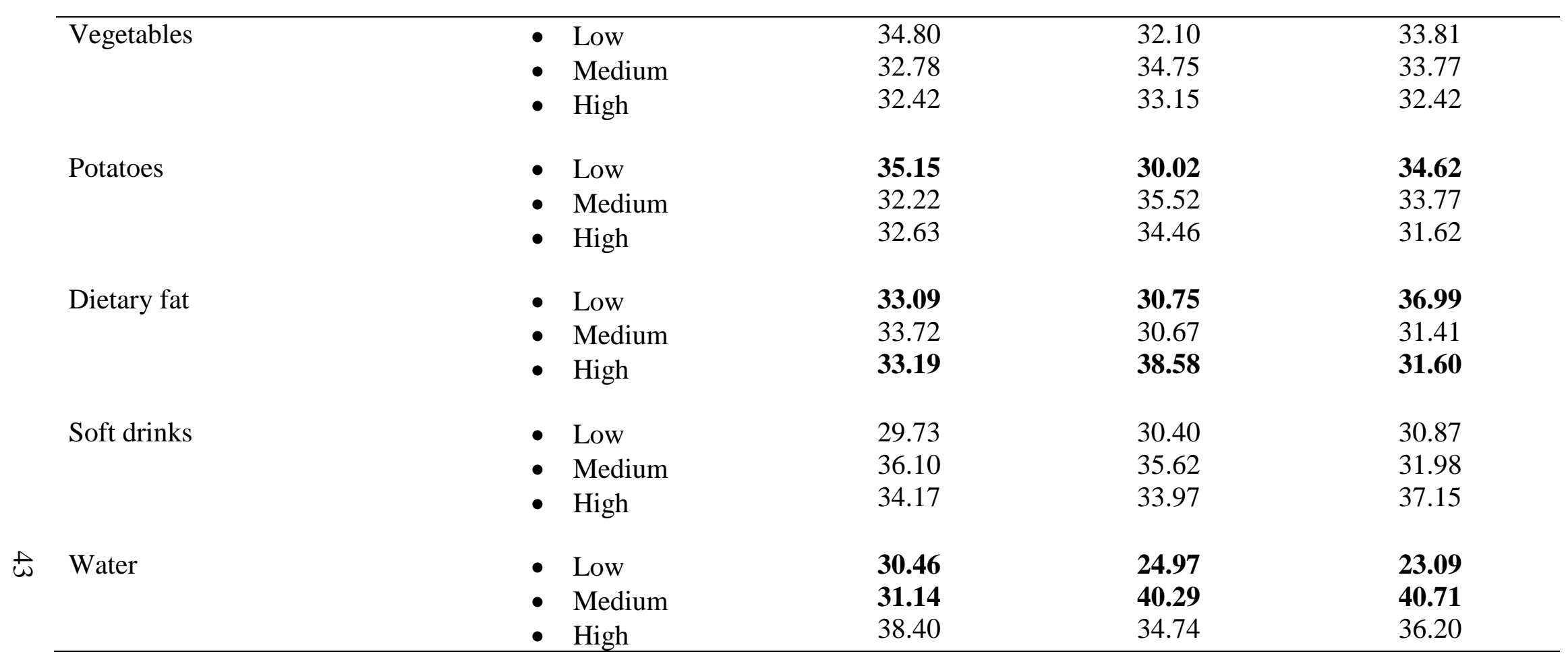

$*_{\mathrm{n}}=$ this is the weighted population number 


\subsubsection{Canada Food Guide}

Table 4.3 shows the overall descriptive statistics for the categories of Canada's Food Guide for all Cycles. The variable "grains" was not included and presented within the description of Canada Food Guide since the cell size did not meet the minimum criteria based on Statistics Canada guidelines. Descriptive statistics of the Canada Food Guide classification by age group are located in Appendix 2. The following patterns were observed overall.

- The proportion of participants who were within the "not meeting" Canada Food Guide requirement of vegetables and fruits increased by Cycles and greatest in Cycle 3.

- The proportion of participants who were within the "not meeting" Canada Food Guide requirement of milk and milk alternatives showed an inverse $U$-shape pattern from Cycle 1 to Cycle 3.

- The proportion of participants who were within the "not meeting" Canada Food Guide requirement of red meat and meat alternatives decreased from Cycle 1 to 3. Cycle 3 had some different dietary information compared to Cycle 1 and 2 may cause this variation. 
Table 4.3 Descriptive statistics (overall) of Canada Food Guide

\begin{tabular}{|c|c|c|c|c|}
\hline \multicolumn{2}{|c|}{ Variables for Canada Food Guide } & Cycle 1 & Cycle 2 & Cycle 3 \\
\hline Vegetables and fruits & $\begin{array}{l}\text { - } 1 \text { - Not meeting } \\
\text { - } 2 \text { - Meeting }\end{array}$ & $\begin{array}{l}89.39 \\
10.61\end{array}$ & $\begin{array}{l}\mathbf{9 1 . 0 1} \\
8.99\end{array}$ & $\begin{array}{l}96.38 \\
3.62\end{array}$ \\
\hline Milk and Milk alternatives & $\begin{array}{l}\text { - } 1 \text { - Not meeting } \\
\text { - } 2 \text { - Meeting }\end{array}$ & $\begin{array}{l}\mathbf{7 4 . 0 5} \\
25.95\end{array}$ & $\begin{array}{l}77.78 \\
22.23\end{array}$ & $\begin{array}{l}\mathbf{6 7 . 8 4} \\
32.16\end{array}$ \\
\hline $\begin{array}{l}\text { Red Meat and meat } \\
\text { alternatives }\end{array}$ & $\begin{array}{l}\text { - } 1 \text { - Not meeting } \\
\text { - } 2 \text { - Meeting }\end{array}$ & $\begin{array}{l}\mathbf{8 5 . 6 9} \\
14.31\end{array}$ & $\begin{array}{l}\mathbf{8 2 . 0 0} \\
18.00\end{array}$ & $\begin{array}{l}36.42 \\
63.58\end{array}$ \\
\hline
\end{tabular}




\subsubsection{Mediterranean Diet and modified Mediterranean Diet Score}

Table 4.4 shows the overall descriptive statistics for the variables of Mediterranean Diet Score for all Cycles. There was a large difference (>5\% difference between Cycles) observed between Cycles in the categories of consuming meats, fish, fruits, pasta, rice, and milk. In addition, the proportion consuming a low amount of food was lowest while the proportion consuming the high amount of food was highest in all food group except fish (all Cycles), pasta (all Cycles), and rice (Cycle 3). The following patterns were observed.

- Red meat consumption was higher in Cycles 1 and 3 compared to Cycle 2.

- Higher or greater fish consumption per week was found in Cycle 3 compared to Cycles 1 and 2.

- Rice consumption was lowest in Cycle 3 compared to Cycles 1 and 2. In rice, most participants who consumed low rice was higher in Cycle 3 compared to Cycles 1 and 2.

- Milk consumption was highest in Cycle 3.

Table 4.5 shows the descriptive statistics of mean (95\% confidence interval), median, mode, $75 \%$ percentile, and $25 \%$ percentile of the Mediterranean Diet Score. Overall, the score was consistent throughout the Cycles. Descriptive statistics by age group are located in Appendix 2. 
Table 4.4 Descriptive statistics (overall) of Mediterranean Diet

\begin{tabular}{|c|c|c|c|c|}
\hline $\begin{array}{c}\text { Variables for modified } \\
\text { Mediterranean Diet } \\
\text { Score } \\
\end{array}$ & $\begin{array}{c}\text { Number of times per } \\
\text { week } \\
\text { (tertiles) }\end{array}$ & $\begin{array}{c}\text { Cycle } 1 \\
\text { Overall } \\
\% \\
\end{array}$ & $\begin{array}{c}\text { Cycle } 2 \\
\text { Overall } \\
\%\end{array}$ & $\begin{array}{c}\text { Cycle } 3 \\
\text { Overall } \\
\%\end{array}$ \\
\hline Red meat & $\begin{array}{ll}\text { - } & \text { Low } \\
\text { - } & \text { Medium } \\
\text { - } & \text { High }\end{array}$ & $\begin{array}{c}0.36 \\
4.90 \\
\mathbf{9 4 . 7 4}\end{array}$ & $\begin{array}{c}9.71 \\
23.68 \\
\mathbf{6 6 . 6 0}\end{array}$ & $\begin{array}{c}0.27 \\
0.93 \\
\mathbf{9 8 . 8 0}\end{array}$ \\
\hline Fish & $\begin{array}{ll}\text { - } & \text { Low } \\
\text { - } & \text { Medium } \\
\text { - } & \text { High }\end{array}$ & $\begin{array}{l}37.58 \\
43.29 \\
\mathbf{1 9 . 1 2}\end{array}$ & $\begin{array}{l}44.48 \\
33.02 \\
\mathbf{2 2 . 5 0}\end{array}$ & $\begin{array}{l}10.97 \\
20.00 \\
\mathbf{6 9 . 0 3}\end{array}$ \\
\hline Fruits & $\begin{array}{ll}\text { - } & \text { Low } \\
\text { - } & \text { Medium } \\
\text { - } & \text { High }\end{array}$ & $\begin{array}{c}6.03 \\
11.50 \\
82.47\end{array}$ & $\begin{array}{c}5.85 \\
12.77 \\
81.37\end{array}$ & $\begin{array}{c}4.04 \\
9.05 \\
86.92\end{array}$ \\
\hline Vegetables & $\begin{array}{ll}\text { - } & \text { Low } \\
\text { - } & \text { Medium } \\
\text { - } & \text { High }\end{array}$ & $\begin{array}{l}- \\
- \\
-\end{array}$ & $\begin{array}{c}0.95 \\
3.68 \\
95.36\end{array}$ & $\begin{array}{c}0.44 \\
3.57 \\
95.98\end{array}$ \\
\hline Cereal & $\begin{array}{ll}\text { - } & \text { Low } \\
\text { - } & \text { Medium } \\
\text { - } & \text { High }\end{array}$ & $\begin{array}{c}1.32 \\
4.30 \\
94.39\end{array}$ & $\begin{array}{c}1.99 \\
4.39 \\
93.63\end{array}$ & $\begin{array}{c}2.72 \\
5.35 \\
91.93\end{array}$ \\
\hline Pasta & $\begin{array}{ll}\text { - } & \text { Low } \\
\text { - } & \text { Medium } \\
\text { - } & \text { High }\end{array}$ & $\begin{array}{l}22.95 \\
53.63 \\
23.42\end{array}$ & $\begin{array}{l}26.08 \\
51.18 \\
22.74\end{array}$ & $\begin{array}{l}29.70 \\
51.22 \\
19.08\end{array}$ \\
\hline Rice & $\begin{array}{ll}\text { - } & \text { Low } \\
\text { - } & \text { Medium } \\
\text { - } & \text { High }\end{array}$ & $\begin{array}{l}\mathbf{2 7 . 0 1} \\
37.73 \\
\mathbf{3 5 . 2 5}\end{array}$ & $\begin{array}{l}\mathbf{2 3 . 4 6} \\
37.89 \\
\mathbf{3 8 . 6 5}\end{array}$ & $\begin{array}{c}\mathbf{7 6 . 5 7} \\
17.97 \\
\mathbf{5 . 4 6} \\
\end{array}$ \\
\hline
\end{tabular}




\begin{tabular}{|c|c|c|c|c|}
\hline Potatoes & $\begin{array}{ll}\text { - } & \text { Low } \\
\text { - } & \text { Medium } \\
\text { - } & \text { High }\end{array}$ & $\begin{array}{l}19.35 \\
36.81 \\
43.84\end{array}$ & $\begin{array}{l}18.53 \\
36.41 \\
45.05\end{array}$ & $\begin{array}{l}19.95 \\
38.75 \\
41.29\end{array}$ \\
\hline Milk & $\begin{array}{ll}\text { - } & \text { Low } \\
\text { - } & \text { Medium } \\
\text { - } & \text { High }\end{array}$ & $\begin{array}{c}6.74 \\
8.11 \\
\mathbf{8 5 . 1 6}\end{array}$ & $\begin{array}{c}8.11 \\
8.63 \\
\mathbf{8 3 . 2 6}\end{array}$ & $\begin{array}{c}1.71 \\
5.34 \\
\mathbf{9 2 . 9 5}\end{array}$ \\
\hline
\end{tabular}


Table 4.5 Modified Mediterranean Diet Score (overall) for all Cycles

\begin{tabular}{|c|c|c|c|}
\hline \multirow{2}{*}{$\begin{array}{c}\text { Mediterranean } \\
\text { Diet Score } \\
\text { (total possible } \\
\text { score }=27 \text { ) }\end{array}$} & Cycle 1 & Cycle 2 & Cycle 3 \\
\hline & Overall score & Overall score & Overall score \\
\hline Mean & 10.09 & 10.46 & 9.76 \\
\hline$(95 \% \mathrm{CI})$ & $(9.99-10.19)$ & $(10.32-10.60)$ & $(9.60-9.92)$ \\
\hline Median & 10 & 11 & 10 \\
\hline Mode & 10 & 11 & 10 \\
\hline $75 \%$ percentile & 11 & 12 & 11 \\
\hline $25 \%$ percentile & 9 & 9 & 9 \\
\hline
\end{tabular}




\subsubsection{Biomarkers}

Table 4.6 shows the overall descriptive statistics for the biomarkers for all Cycles. On average, all of the mean values of biomarkers were within their normal ranges except total cholesterol in Cycle 1 and 2 where it was higher than recommended values $(>5.19 \mathrm{mmol} / \mathrm{L})$ and Vitamin D in Cycle 1, 2, and 3 where it was lower than recommended values $(<75 \mathrm{nmol} / \mathrm{L})$ $(138,139)$. The biomarker descriptive statistics are presented by age group in Appendix 2. 
Table 4.6 Descriptive statistics (overall) of biomarkers for all Cycles

\begin{tabular}{|c|c|c|c|c|}
\hline Biomarkers & Normal range & $\begin{array}{c}\text { Cycle 1 } \\
\left(\mathrm{n}^{*}=24,531,089\right) \\
\text { Overall } \\
(\text { Mean, SE) }\end{array}$ & $\begin{array}{c}\text { Cycle 2 } \\
(\mathrm{n} *=25,327,408) \\
\text { Overall } \\
(\text { Mean, SE) }\end{array}$ & $\begin{array}{c}\text { Cycle 3 } \\
\left(\mathrm{n}^{*}=25,974,338\right) \\
\text { Overall } \\
(\text { Mean, SE) }\end{array}$ \\
\hline Red blood cell folate (nmol/L) & $317-1422^{a}$ & $1355.80 \pm 43.23$ & $1270.07 \pm 32.39$ & $1269.26 \pm 44.71$ \\
\hline Vitamin D (nmol/L) & $75-150^{b}$ & $67.32 \pm 1.20$ & $69.48 \pm 2.27$ & $61.20 \pm 2.70$ \\
\hline Total protein $(\mathrm{g} / \mathrm{L})$ & $60-80^{b}$ & $73.50 \pm 0.19$ & $72.48 \pm 0.20$ & $71.64 \pm 0.32$ \\
\hline Chloride (mmol/L) & $98-108^{b}$ & $104.38 \pm 0.12$ & $103.74 \pm 0.09$ & $104.11 \pm 0.15$ \\
\hline Potassium (mmol/L) & $\begin{array}{c}\text { Men: } 3.5-4.5^{\mathrm{b}} \\
\text { Women: } 3.4-4.4^{\mathrm{b}}\end{array}$ & $4.31 \pm 0.02$ & $4.47 \pm 0.01$ & $4.37 \pm 0.02$ \\
\hline Sodium (mmol/L) & $135-145^{b}$ & $139.95 \pm 0.14$ & $140.00 \pm 0.20$ & $141.44 \pm 0.19$ \\
\hline Calcium (total) (mmol/L) & $2.10-2.60^{b}$ & $2.41 \pm 0.01$ & $2.41 \pm 0.004$ & $2.41 \pm 0.01$ \\
\hline $\begin{array}{l}\text { High Density Lipoprotein (HDL) } \\
(\mathrm{mmol} / \mathrm{L})\end{array}$ & $\begin{array}{c}\text { Men: }>0.99^{\mathrm{b}} \\
\text { Women: }\end{array}$ & $1.33 \pm 0.02$ & $1.41 \pm 0.02$ & $1.38 \pm 0.02$ \\
\hline Total cholesterol (mmol/L) & $2.0-5.19^{b}$ & $7.26 \pm 0.64$ & $5.78 \pm 0.25$ & $4.82 \pm 0.05$ \\
\hline C-reactive protein $(\mathrm{mg} / \mathrm{L})$ & Intermediate risk: $1.0-3.0^{\mathrm{b}}$ & $2.33 \pm 0.07$ & $2.42 \pm 0.08$ & $2.55 \pm 0.14$ \\
\hline Vitamin B12 (pmol/L) & $153-655^{b}$ & $334.08 \pm 3.99$ & $347.10 \pm 6.45$ & $322.31 \pm 8.28$ \\
\hline
\end{tabular}

$*_{\mathrm{n}}=$ this is the weighted population number

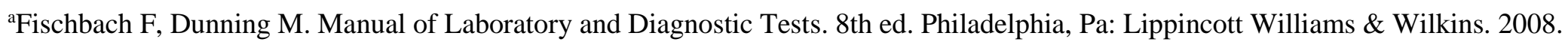

b LifeLabs (Burnaby reference laboratory). Reference Ranges - Healthcare Providers. 2017. 
4.2 Research question 1 (What are the characteristics/status of lung function (FEV,$F V C$, $\mathrm{FEV}_{1} / \mathrm{FVC}$ ratio, and $\mathrm{FEF}_{25-75 \%)}$ in Canadian adults (18-79 years)?)

Table 4.7 presents the descriptive statistics of absolute and percent predicted lung function status ( $\mathrm{FVC}, \mathrm{FEV}_{1}$, and $\mathrm{FEV}_{1} / \mathrm{FVC}$ ratio) by age group. Percent predicted variables were calculated by Statistics Canada and $\mathrm{FEF}_{25-75 \%}$ did not have the variable for the percent predicted equation included in the CHMS, therefore only absolute values for this measure are presented. With regard to absolute values, it was observed that on average, younger adults had higher lung function status than the middle age adults. Similarly, the middle age adults had higher lung function status than the older adults. Therefore, as age increased, lung function decreased consistently throughout the Cycles (1,2, and 3). In general, the same patterns occurred for percent predicted results with the exception of $\mathrm{FEV}_{1}$ (Cycle 3) and $\mathrm{FEV}_{1} / \mathrm{FVC}$ ratio (Cycles 1, 2, and 3). The percent predicted $\mathrm{FEV}_{1}$ showed an U-shaped pattern in Cycle 3. Again, in Cycles 2 and 3, the percent predicted $\mathrm{FEV}_{1} / \mathrm{FVC}$ increased with increasing of age. 
Table 4.7 Descriptive statistics of lung function status by age group adjusted* for sex, height, and race in each Cycle

\begin{tabular}{|c|c|c|c|c|c|c|}
\hline \multirow[t]{2}{*}{ Outcome variable } & \multicolumn{2}{|c|}{$\begin{array}{c}\text { Cycle 1 } \\
(n *=24,531,089)\end{array}$} & \multicolumn{2}{|c|}{$\begin{array}{c}\text { Cycle 2 } \\
(\mathrm{n} *=25,327,408)\end{array}$} & \multicolumn{2}{|c|}{$\begin{array}{c}\text { Cycle 3 } \\
\left(n^{*}=25,974,338\right)\end{array}$} \\
\hline & $\begin{array}{c}\text { Absolute } \\
\text { (Mean/95\% } \\
\text { CI) }\end{array}$ & $\begin{array}{c}\% \text { predicted } \\
(\text { Mean/95\% CI) }\end{array}$ & $\begin{array}{c}\text { Absolute } \\
\text { (Mean/95\% } \\
\text { CI) }\end{array}$ & $\begin{array}{c}\text { \% predicted } \\
(\text { Mean } / 95 \% \\
\text { CI) }\end{array}$ & $\begin{array}{c}\text { Absolute } \\
\text { (Mean/95\% } \\
\text { CI) }\end{array}$ & $\begin{array}{c}\text { \% predicted } \\
(\text { Mean } / 95 \% \\
\mathrm{CI})\end{array}$ \\
\hline \multicolumn{7}{|l|}{ FVC (L) } \\
\hline Younger adult & $\begin{array}{c}4.35 \\
(4.27-4.43)\end{array}$ & $\begin{array}{c}101.16 \\
(100.22-102.11)\end{array}$ & $\begin{array}{c}4.34 \\
(4.28-4.40)\end{array}$ & $\begin{array}{c}100.59 \\
(71.18-129.99)\end{array}$ & $\begin{array}{c}4.39 \\
(4.31-4.47)\end{array}$ & $\begin{array}{c}100.97 \\
(99.74-102.21)\end{array}$ \\
\hline Middle age & $\begin{array}{c}3.86 \\
(3.78-3.94)\end{array}$ & $\begin{array}{c}97.59 \\
(96.59-98.58)\end{array}$ & $\begin{array}{c}3.82 \\
(3.76-3.88)\end{array}$ & $\begin{array}{c}96.76 \\
(69.93-123.60)\end{array}$ & $\begin{array}{c}3.81 \\
(3.71-3.91)\end{array}$ & $\begin{array}{c}95.74 \\
(93.92-97.56)\end{array}$ \\
\hline Older person & $\begin{array}{c}3.24 \\
(3.14-3.34)\end{array}$ & $\begin{array}{c}96.23 \\
(93.65-98.80)\end{array}$ & $\begin{array}{c}3.18 \\
(3.10-3.26)\end{array}$ & $\begin{array}{c}94.11 \\
(61.22-127.01)\end{array}$ & $\begin{array}{c}3.26 \\
(3.18-3.34)\end{array}$ & $\begin{array}{c}94.40 \\
(93.04-95.77)\end{array}$ \\
\hline \multicolumn{7}{|l|}{$\operatorname{FEV}_{1}(\mathrm{~L} / \mathrm{s})$} \\
\hline Younger adult & $\begin{array}{c}3.53 \\
(3.47-3.59)\end{array}$ & $\begin{array}{c}97.60 \\
(96.46-98.73)\end{array}$ & $\begin{array}{c}3.52 \\
(3.46-3.58)\end{array}$ & $\begin{array}{c}97.11 \\
(68.21-126.01)\end{array}$ & $\begin{array}{c}3.53 \\
(3.47-3.59)\end{array}$ & $\begin{array}{c}96.78 \\
(95.48-98.09)\end{array}$ \\
\hline Middle age & $\begin{array}{c}2.96 \\
(2.88-3.04)\end{array}$ & $\begin{array}{c}94.41 \\
(93.09-95.74)\end{array}$ & $\begin{array}{c}2.94 \\
(2.90-2.98)\end{array}$ & $\begin{array}{c}94.72 \\
(68.72-120.72)\end{array}$ & $\begin{array}{c}2.93 \\
(2.85-3.01)\end{array}$ & $\begin{array}{c}93.67 \\
(91.76-95.58)\end{array}$ \\
\hline Older person & $\begin{array}{c}2.35 \\
(2.27-2.43)\end{array}$ & $\begin{array}{c}93.37 \\
(90.70-96.04)\end{array}$ & $\begin{array}{c}2.36 \\
(2.30-2.42)\end{array}$ & $\begin{array}{c}93.59 \\
(49.75-137.42)\end{array}$ & $\begin{array}{c}2.42 \\
(2.36-2.48)\end{array}$ & $\begin{array}{c}94.05 \\
(92.23-95.86)\end{array}$ \\
\hline \multicolumn{7}{|l|}{$\mathrm{FEV}_{1} / \mathrm{FVC}$ ratio $(\%)$} \\
\hline Younger adult & $\begin{array}{c}0.82 \\
(0.81-0.83)\end{array}$ & $\begin{array}{c}96.69 \\
(96.00-97.39)\end{array}$ & $\begin{array}{c}0.81 \\
(0.80-0.82)\end{array}$ & $\begin{array}{c}96.68 \\
(71.14-122.23)\end{array}$ & $\begin{array}{c}0.81 \\
(0.80-0.82)\end{array}$ & $\begin{array}{c}96.02 \\
(94.98-97.05)\end{array}$ \\
\hline Middle age & $\begin{array}{c}0.77 \\
(0.76-0.78)\end{array}$ & $\begin{array}{c}96.28 \\
(95.63-96.93)\end{array}$ & $\begin{array}{c}0.77 \\
(0.77-0.77)\end{array}$ & $\begin{array}{c}97.39 \\
(81.95-112.83)\end{array}$ & $\begin{array}{c}0.77 \\
(0.76-0.78)\end{array}$ & $\begin{array}{c}97.34 \\
(96.38-98.30)\end{array}$ \\
\hline Older person & $\begin{array}{c}0.73 \\
(0.72-0.74) \\
\end{array}$ & $\begin{array}{c}96.33 \\
(95.72-96.94) \\
\end{array}$ & $\begin{array}{c}0.75 \\
(0.74-0.76) \\
\end{array}$ & $\begin{array}{c}98.96 \\
(71.63-126.30)\end{array}$ & $\begin{array}{c}0.75 \\
(0.74-0.76)\end{array}$ & $\begin{array}{c}99.10 \\
(97.96-100.24) \\
\end{array}$ \\
\hline
\end{tabular}




\begin{tabular}{|c|c|c|c|c|c|c|}
\hline \multicolumn{7}{|l|}{ FEF $25-75 \%_{(\mathrm{L} / \mathrm{s})}$} \\
\hline Younger adult & $\begin{array}{c}3.51 \\
(3.41-3.61)\end{array}$ & - & $\begin{array}{c}3.34 \\
(3.16-3.52)\end{array}$ & - & $\begin{array}{c}3.49 \\
(3.39-3.59)\end{array}$ & - \\
\hline Middle age & $\begin{array}{c}2.68 \\
(2.58-2.78)\end{array}$ & - & $\begin{array}{c}2.60 \\
(2.54-2.66)\end{array}$ & - & $\begin{array}{c}2.65 \\
(2.55-2.75)\end{array}$ & - \\
\hline Older person & $\begin{array}{c}1.82 \\
(1.70-1.94)\end{array}$ & - & $\begin{array}{c}1.87 \\
(1.77-1.97)\end{array}$ & - & $\begin{array}{c}1.99 \\
(1.93-2.05)\end{array}$ & - \\
\hline
\end{tabular}

*Adjusted for sex, height, and ethnicity

$\%$ predicted values were based on Hankinson's predictive equation

$*_{n}=$ this is the weighted population number

$95 \% \mathrm{CI}=95 \%$ confidence interval 
4.3 Research question 2. A (Are dietary factors such as consumption of meat, fish, fruits, vegetables, grains, milk and milk products, dietary fat, and soft drinks associated with lung function levels based on spirometry in a nationally representative Canadian population of adults?)

\subsection{Dietary factors based on questionnaire}

Tables 4.8, 4.9, 4.10, and 4.11 show the results from the multivariate analysis of the main effects model for each of the four outcome variables (FVC, $\mathrm{FEV}_{1}, \mathrm{FEV}_{1} / \mathrm{FVC}$ ratio, and $\mathrm{FEF}_{25}$ $75 \%$, respectively). The main effects models were fitted to investigate the association between each of the groups of nutrition markers with each outcome in independent models. The groups of nutritional markers included: 1) individual dietary variables, 2) variables based on the Canada Food Guide, and 3) the modified Mediterranean Diet Score. In Cycle 3, the variable "grains" of the Canada Food Guide had less than 10 observations in one of the categories and it was not included in any model for Cycle 3. All models were adjusted for age, sex, race, height, immigration status, marital status, education, income, BMI, smoking status, smoking exposure, alcohol drinking, current asthma, other respiratory diseases, family history of asthma, physical activity, and sedentary activity.

For the outcome of FVC (Table 4.8), statistically significant relationships $(\mathrm{p}<0.05)$ were found for beans, grains, vegetables, potatoes, dietary fat, and soft drinks.

- High consumption of beans was associated with higher FVC (Cycle 3).

- Medium consumption of grains was associated with higher FVC (Cycle 3).

- Medium consumption of vegetables was associated with higher FVC (Cycle 3).

- Medium and high consumption of potatoes were associated with lower FVC (Cycle 3).

- High consumption of dietary fat was associated with higher FVC (Cycle 1, 2).

- High consumption of soft drinks was associated with lower FVC (Cycle 2). 
In Cycle 3, the Mediterranean Diet Score was statistically significant $(\mathrm{p}<0.05)$ and associated with lower FVC. There were no statistically significant associations observed for the variables of the Canada Food Guide. 
Table 4.8 Multivariate analysis of dietary factors, Canada Food Guide, and modified Mediterranean Diet Score with FVC

\begin{tabular}{|c|c|c|c|c|c|c|c|c|c|}
\hline \multirow[t]{2}{*}{ Variables } & \multicolumn{3}{|c|}{ Cycle 1} & \multicolumn{3}{|c|}{ Cycle 2} & \multicolumn{3}{|c|}{ Cycle 3} \\
\hline & B & $\begin{array}{c}\text { Standard } \\
\text { error (SE) }\end{array}$ & P-value & B & $\begin{array}{c}\text { Standard } \\
\text { error }(\mathrm{SE})\end{array}$ & P-value & B & $\begin{array}{c}\text { Standard } \\
\text { error }(\mathrm{SE})\end{array}$ & $\begin{array}{c}\mathrm{P}- \\
\text { value }\end{array}$ \\
\hline Dietary & & & & & & & & & \\
\hline $\begin{array}{l}\text { Red meat } \\
\text { consumption } \\
\text { - Low (ref) } \\
\text { - Medium } \\
\text { - High }\end{array}$ & $\begin{array}{c}- \\
0.042 \\
0.022\end{array}$ & $\begin{array}{c}- \\
0.040 \\
0.041\end{array}$ & $\begin{array}{c}- \\
0.29 \\
0.59\end{array}$ & $\begin{array}{c}- \\
0.023 \\
0.020\end{array}$ & $\begin{array}{c}- \\
0.034 \\
0.034\end{array}$ & $\begin{array}{c}- \\
0.50 \\
0.56\end{array}$ & $\begin{array}{c}- \\
-0.010 \\
0.017\end{array}$ & $\begin{array}{c}- \\
0.058 \\
0.038\end{array}$ & $\begin{array}{c}- \\
0.86 \\
0.65\end{array}$ \\
\hline $\begin{array}{c}\text { Fish consumption } \\
\text { - Low (ref) } \\
\text { - Medium } \\
\text { - High }\end{array}$ & $\begin{array}{c}- \\
-0.012 \\
-0.029\end{array}$ & $\begin{array}{c}- \\
0.031 \\
0.034\end{array}$ & $\begin{array}{l}- \\
0.71 \\
0.38\end{array}$ & $\begin{array}{c}- \\
0.023 \\
0.042\end{array}$ & $\begin{array}{c}- \\
0.038 \\
0.041\end{array}$ & $\begin{array}{c}- \\
0.55 \\
0.31\end{array}$ & $\begin{array}{r}- \\
-0.049 \\
0.017\end{array}$ & $\begin{array}{c}- \\
0.069 \\
0.051\end{array}$ & $\begin{array}{c}- \\
0.48 \\
0.74\end{array}$ \\
\hline $\begin{array}{cl}\text { Eggs consumption } \\
- \text { Low (ref) } \\
\text { - Medium } \\
\text { - High }\end{array}$ & $\begin{array}{c}- \\
0.013 \\
0.074\end{array}$ & $\begin{array}{c}- \\
0.058 \\
0.045\end{array}$ & $\begin{array}{c}- \\
0.83 \\
0.10\end{array}$ & $\begin{array}{r}- \\
0.029 \\
-0.014\end{array}$ & $\begin{array}{c}- \\
0.055 \\
0.041\end{array}$ & $\begin{array}{c}- \\
0.59 \\
0.73\end{array}$ & $\begin{array}{c}- \\
0.016 \\
-0.026\end{array}$ & $\begin{array}{c}- \\
0.046 \\
0.032\end{array}$ & $\begin{array}{c}- \\
0.73 \\
0.41\end{array}$ \\
\hline $\begin{array}{cl}\text { Beans consumptio } \\
\text { - Low (ref) } \\
\text { - Medium } \\
\text { - High }\end{array}$ & $\begin{array}{c}- \\
-0.002 \\
0.046\end{array}$ & $\begin{array}{c}- \\
0.032 \\
0.051\end{array}$ & $\begin{array}{c}- \\
0.95 \\
0.37\end{array}$ & $\begin{array}{c}- \\
0.040 \\
-0.030\end{array}$ & $\begin{array}{c}- \\
0.041 \\
0.043\end{array}$ & $\begin{array}{c}- \\
0.34 \\
0.48\end{array}$ & $\begin{array}{c}- \\
0.048 \\
0.108\end{array}$ & $\begin{array}{l}- \\
0.037 \\
0.035\end{array}$ & $\begin{array}{c}- \\
0.19 \\
0.002\end{array}$ \\
\hline $\begin{array}{cl}\text { Milk consumption } \\
\text { - Low (ref) } \\
\text { - Medium } \\
\text { - High }\end{array}$ & $\begin{array}{r}- \\
-0.001 \\
0.022\end{array}$ & $\begin{array}{c}- \\
0.027 \\
0.025\end{array}$ & $\begin{array}{l}- \\
0.98 \\
0.39\end{array}$ & $\begin{array}{c}- \\
0.015 \\
0.003\end{array}$ & $\begin{array}{c}- \\
0.036 \\
0.052\end{array}$ & $\begin{array}{c}- \\
0.69 \\
0.95\end{array}$ & $\begin{array}{c}- \\
0.054 \\
0.003\end{array}$ & $\begin{array}{c}- \\
0.029 \\
0.041\end{array}$ & $\begin{array}{c}- \\
0.06 \\
0.95\end{array}$ \\
\hline
\end{tabular}




\begin{tabular}{|c|c|c|c|c|c|c|c|c|c|}
\hline \multicolumn{10}{|l|}{ Grains consumption } \\
\hline - Low (ref) & - & - & - & - & - & - & - & - & - \\
\hline - Medium & -0.046 & 0.039 & 0.23 & 0.048 & 0.037 & 0.19 & 0.124 & 0.051 & 0.015 \\
\hline - High & -0.015 & 0.028 & 0.59 & 0.057 & 0.040 & 0.15 & 0.041 & 0.066 & $\mathbf{0 . 5 3}$ \\
\hline \multicolumn{10}{|l|}{ Fruits consumption } \\
\hline - Low (ref) & - & - & - & - & - & - & - & - & - \\
\hline - Medium & -0.023 & 0.031 & 0.47 & 0.050 & 0.067 & 0.46 & -0.033 & 0.066 & 0.62 \\
\hline - High & 0.016 & 0.045 & 0.72 & 0.023 & 0.036 & 0.52 & 0.072 & 0.049 & 0.14 \\
\hline \multicolumn{10}{|l|}{$\begin{array}{l}\text { Vegetables } \\
\text { consumption }\end{array}$} \\
\hline - Low (ref) & - & - & - & - & - & - & - & - & - \\
\hline - Medium & -0.028 & 0.037 & 0.45 & -0.014 & 0.038 & 0.72 & 0.087 & 0.026 & 0.001 \\
\hline - High & -0.048 & 0.029 & 0.10 & -0.008 & 0.054 & 0.88 & -0.010 & 0.031 & 0.74 \\
\hline \multicolumn{10}{|l|}{ Potatoes } \\
\hline consumption & - & - & - & - & - & - & - & - & - \\
\hline - Low (ref) & 0.009 & 0.037 & 0.82 & 0.043 & 0.046 & 0.35 & -0.132 & 0.039 & 0.001 \\
\hline - Medium & -0.042 & 0.037 & 0.25 & 0.011 & 0.037 & 0.76 & -0.125 & 0.060 & 0.039 \\
\hline - High & & & & & & & & & \\
\hline \multicolumn{10}{|l|}{ Fat consumption } \\
\hline - Low (ref) & - & - & - & - & - & - & - & - & - \\
\hline - Medium & $\mathbf{0 . 0 2 8}$ & 0.025 & 0.27 & 0.073 & 0.039 & 0.06 & 0.063 & 0.054 & 0.24 \\
\hline - High & 0.098 & 0.043 & 0.024 & 0.132 & 0.039 & 0.001 & -0.0002 & 0.045 & 0.99 \\
\hline \multicolumn{10}{|l|}{$\begin{array}{l}\text { Soft drinks } \\
\text { consumption }\end{array}$} \\
\hline - Low (ref) & - & - & - & - & - & - & - & - & - \\
\hline - Medium & -0.016 & 0.041 & 0.69 & -0.033 & 0.049 & 0.51 & -0.012 & 0.043 & 0.78 \\
\hline - High & -0.014 & 0.045 & 0.76 & -0.146 & 0.045 & 0.001 & -0.001 & 0.052 & 0.99 \\
\hline Water consumption & & & & & & & & & \\
\hline
\end{tabular}




\begin{tabular}{|c|c|c|c|c|c|c|c|c|c|}
\hline $\begin{array}{ll}\text { - } & \text { Low (ref) } \\
\text { - } & \text { Medium } \\
\text { - } & \text { High }\end{array}$ & $\begin{array}{c}- \\
-0.002 \\
0.001\end{array}$ & $\begin{array}{c}- \\
0.041 \\
0.045\end{array}$ & $\begin{array}{l}- \\
0.95 \\
0.99\end{array}$ & $\begin{array}{c}- \\
0.045 \\
0.022\end{array}$ & $\begin{array}{c}- \\
0.049 \\
0.051\end{array}$ & $\begin{array}{l}- \\
0.36 \\
0.67\end{array}$ & $\begin{array}{c}- \\
0.006 \\
-0.061\end{array}$ & $\begin{array}{c}- \\
0.032 \\
0.069\end{array}$ & $\begin{array}{c}- \\
0.85 \\
0.38\end{array}$ \\
\hline $\begin{array}{l}\text { Canada Food } \\
\text { Guide }\end{array}$ & & & & & & & & & \\
\hline $\begin{array}{c}\text { Vegetables and fruits } \\
\text { - Not-meeting } \\
\text { - Meeting }\end{array}$ & $\begin{array}{c}-0.038 \\
-\end{array}$ & $\begin{array}{c}0.061 \\
-\end{array}$ & $\begin{array}{c}0.54 \\
-\end{array}$ & $\begin{array}{c}0.051 \\
-\end{array}$ & $\begin{array}{c}0.075 \\
-\end{array}$ & $\begin{array}{c}0.50 \\
-\end{array}$ & $\begin{array}{c}-0.104 \\
-\end{array}$ & $\begin{array}{c}0.062 \\
-\end{array}$ & $\begin{array}{c}0.09 \\
-\end{array}$ \\
\hline $\begin{array}{l}\text { Grains } \\
\text { - Not-meeting } \\
\text { - Meeting }\end{array}$ & $\begin{array}{c}-0.185 \\
-\end{array}$ & $\begin{array}{c}0.394 \\
-\end{array}$ & $\begin{array}{c}0.64 \\
-\end{array}$ & $\begin{array}{c}0.236 \\
-\end{array}$ & $\begin{array}{c}0.366 \\
-\end{array}$ & $\begin{array}{c}0.52 \\
-\end{array}$ & - & - & - \\
\hline $\begin{aligned} \text { Milk } & \\
\bullet & \text { Not-meeting } \\
\text { - } & \text { Meeting }\end{aligned}$ & $\begin{array}{c}-0.040 \\
-\end{array}$ & $\begin{array}{c}0.034 \\
-\end{array}$ & $\begin{array}{c}0.25 \\
-\end{array}$ & $\begin{array}{c}-0.005 \\
-\end{array}$ & $\begin{array}{c}0.051 \\
-\end{array}$ & $\begin{array}{c}0.92 \\
-\end{array}$ & $\begin{array}{c}-0.033 \\
-\end{array}$ & $\begin{array}{c}0.046 \\
-\end{array}$ & $\begin{array}{c}0.47 \\
-\end{array}$ \\
\hline $\begin{array}{cl}\text { Meats } & \\
\text { - } & \text { Not-meeting } \\
\text { - } & \text { Meeting }\end{array}$ & $\begin{array}{c}-0.039 \\
-\end{array}$ & $\begin{array}{c}0.041 \\
-\end{array}$ & $\begin{array}{c}0.33 \\
-\end{array}$ & $\begin{array}{c}-0.002 \\
-\end{array}$ & $\begin{array}{c}0.033 \\
-\end{array}$ & $\begin{array}{c}0.95 \\
-\end{array}$ & $\begin{array}{c}0.008 \\
-\end{array}$ & $\begin{array}{c}0.030 \\
-\end{array}$ & $\begin{array}{c}0.78 \\
-\end{array}$ \\
\hline Mediterranean Diet & & & & & & & & & \\
\hline $\begin{array}{l}\text { Modified } \\
\text { Mediterranean Diet } \\
\text { Score }\end{array}$ & -0.003 & 0.007 & 0.63 & 0.001 & 0.008 & 0.89 & -0.017 & 0.008 & 0.035 \\
\hline
\end{tabular}


For $\mathrm{FEV}_{1}$, (Table 4.9), within the dietary variables, statistically significant $(\mathrm{p}<0.05)$ associations were found for consuming eggs, beans, milk, grains, fruits, vegetables, potatoes, dietary fat, and soft drinks.

- High consumption of eggs was associated with higher FEV $\mathrm{F}_{1}$ in Cycle 1, while in Cycle 3, the high consumption of eggs was associated with lower $\mathrm{FEV}_{1}$.

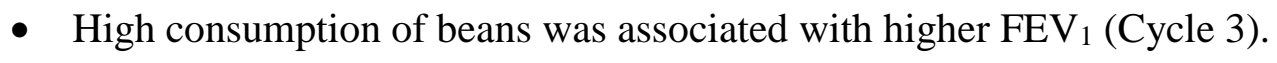

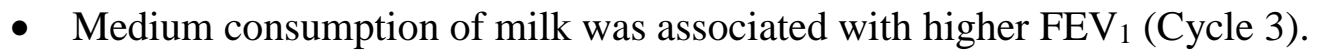

- Medium consumption of grains was associated with higher $\mathrm{FEV}_{1}$ (Cycle 3).

- High consumption of fruits was associated with higher FEV 1 (Cycle 3).

- Medium consumption of vegetables was associated with higher $\mathrm{FEV}_{1}$ (Cycle 3).

- High and medium consumption of potatoes were associated with lower $\mathrm{FEV}_{1}$ (Cycle 3).

- High consumption of dietary fat was associated with higher FEV 1 (Cycle 2).

- High consumption of soft drinks was associated with lower $\mathrm{FEV}_{1}$ (Cycle 2).

Using the Canada Food Guide, "not meeting" fruits and vegetables (Cycle 3) and meat (Cycle 1) requirements resulted in statistically significant $(\mathrm{p}<0.05)$ associations where both were associated with lower $\mathrm{FEV}_{1}$. The modified Mediterranean Diet Score (Cycle 3) was also statistically significant $(\mathrm{p}<0.05)$ and associated with the lower $\mathrm{FEV}_{1}$. 
Table 4.9 Multivariate analysis of dietary factors, Canada Food Guide, and modified Mediterranean Diet Score with FEV 1

\begin{tabular}{|c|c|c|c|c|c|c|c|c|c|}
\hline \multirow[t]{2}{*}{ Variables } & \multicolumn{3}{|c|}{ Cycle 1} & \multicolumn{3}{|c|}{ Cycle 2} & \multicolumn{3}{|c|}{ Cycle 3} \\
\hline & B & $\begin{array}{l}\text { Standard } \\
\text { error (SE) }\end{array}$ & $\begin{array}{c}\mathrm{P}- \\
\text { value }\end{array}$ & $\beta$ & $\begin{array}{l}\text { Standard } \\
\text { error (SE) }\end{array}$ & $\begin{array}{c}\mathrm{P}- \\
\text { value }\end{array}$ & $\beta$ & $\begin{array}{l}\text { Standard } \\
\text { error (SE) }\end{array}$ & $\mathrm{P}$-value \\
\hline Dietary & & & & & & & & & \\
\hline $\begin{array}{l}\text { Red meat } \\
\text { consumption } \\
\text { - Low (ref) } \\
\text { - Medium } \\
\text { - High }\end{array}$ & $\begin{array}{c}- \\
0.046 \\
0.016\end{array}$ & $\begin{array}{c}- \\
0.031 \\
0.029\end{array}$ & $\begin{array}{c}- \\
0.14 \\
0.58\end{array}$ & $\begin{array}{c}- \\
0.010 \\
-0.011\end{array}$ & $\begin{array}{c}- \\
0.040 \\
0.037\end{array}$ & $\begin{array}{c}- \\
0.81 \\
0.76\end{array}$ & $\begin{array}{c}- \\
-0.001 \\
0.054\end{array}$ & $\begin{array}{c}- \\
0.049 \\
0.033\end{array}$ & $\begin{array}{c}- \\
0.99 \\
0.10\end{array}$ \\
\hline $\begin{array}{c}\text { Fish consumption } \\
-\quad \text { Low (ref) } \\
\text { - Medium } \\
\text { - High }\end{array}$ & $\begin{array}{c}- \\
-0.038 \\
-0.057\end{array}$ & $\begin{array}{c}- \\
0.032 \\
0.038\end{array}$ & $\begin{array}{c}- \\
0.23 \\
0.13\end{array}$ & $\begin{array}{c}- \\
0.011 \\
0.024\end{array}$ & $\begin{array}{c}- \\
0.033 \\
0.034\end{array}$ & $\begin{array}{c}- \\
0.75 \\
0.48\end{array}$ & $\begin{array}{c}- \\
-0.059 \\
-0.010\end{array}$ & $\begin{array}{c}- \\
0.062 \\
0.044\end{array}$ & $\begin{array}{c}- \\
0.34 \\
0.82\end{array}$ \\
\hline $\begin{array}{c}\text { Eggs consumption } \\
\text { - Low (ref) } \\
\text { - Medium } \\
\text { - High }\end{array}$ & $\begin{array}{l}- \\
0.012 \\
0.071\end{array}$ & $\begin{array}{l}- \\
0.035 \\
0.024\end{array}$ & $\begin{array}{c}- \\
0.72 \\
0.004\end{array}$ & $\begin{array}{c}- \\
0.023 \\
0.004\end{array}$ & $\begin{array}{c}- \\
0.039 \\
0.038\end{array}$ & $\begin{array}{c}- \\
0.56 \\
0.92\end{array}$ & $\begin{array}{c}- \\
0.016 \\
-0.070\end{array}$ & $\begin{array}{l}- \\
0.032 \\
0.035\end{array}$ & $\begin{array}{c}- \\
0.60 \\
0.042\end{array}$ \\
\hline $\begin{array}{c}\text { Beans consumptio } \\
\text { - Low (ref) } \\
\text { - Medium } \\
\text { - High }\end{array}$ & $\begin{array}{c}- \\
0.015 \\
0.044\end{array}$ & $\begin{array}{c}- \\
0.023 \\
0.040\end{array}$ & $\begin{array}{c}- \\
0.51 \\
0.28\end{array}$ & $\begin{array}{c}- \\
0.052 \\
-0.018\end{array}$ & $\begin{array}{c}- \\
0.036 \\
0.032\end{array}$ & $\begin{array}{c}- \\
0.15 \\
0.56\end{array}$ & $\begin{array}{l}- \\
0.058 \\
0.082\end{array}$ & $\begin{array}{c}- \\
0.030 \\
0.032\end{array}$ & $\begin{array}{c}- \\
0.06 \\
0.010\end{array}$ \\
\hline $\begin{array}{c}\text { Milk consumption } \\
\text { - Low (ref) } \\
\text { - Medium } \\
\text { - High }\end{array}$ & $\begin{array}{c}- \\
-0.005 \\
0.009\end{array}$ & $\begin{array}{c}- \\
0.027 \\
0.019\end{array}$ & $\begin{array}{l}- \\
0.85 \\
0.65\end{array}$ & $\begin{array}{c}- \\
0.002 \\
0.009\end{array}$ & $\begin{array}{c}- \\
0.037 \\
0.034\end{array}$ & $\begin{array}{c}- \\
0.96 \\
0.79\end{array}$ & $\begin{array}{c}- \\
0.094 \\
0.016\end{array}$ & $\begin{array}{c}- \\
0.032 \\
0.044\end{array}$ & $\begin{array}{c}- \\
0.003 \\
0.72\end{array}$ \\
\hline $\begin{array}{c}\text { Grains consumptio } \\
\bullet \text { Low (ref) }\end{array}$ & - & - & - & - & - & - & - & - & - \\
\hline
\end{tabular}




\begin{tabular}{|c|c|c|c|c|c|c|c|c|c|}
\hline $\begin{array}{ll}\text { - } & \text { Medium } \\
\text { - } & \text { High }\end{array}$ & $\begin{array}{l}-0.025 \\
-0.026\end{array}$ & $\begin{array}{l}0.026 \\
0.029\end{array}$ & $\begin{array}{l}0.33 \\
0.35\end{array}$ & $\begin{array}{l}0.013 \\
0.027\end{array}$ & $\begin{array}{l}0.029 \\
0.026\end{array}$ & $\begin{array}{l}0.66 \\
0.29\end{array}$ & $\begin{array}{l}0.086 \\
0.027\end{array}$ & $\begin{array}{l}0.045 \\
0.050\end{array}$ & $\begin{array}{c}0.047 \\
0.59\end{array}$ \\
\hline
\end{tabular}

Fruits consumption

- Low (ref)

- Medium

- High

$\begin{array}{cc}- & - \\ -0.004 & 0.038 \\ 0.016 & 0.035\end{array}$

-
0.91
0.64

$\begin{array}{cc}- & - \\ 0.060 & 0.050 \\ 0.059 & 0.038\end{array}$

-
0.23
0.12

$-\overline{0.013}$

-

0.82

Vegetables

consumption

- Low (ref)

- Medium

- High

$$
\begin{aligned}
& -0.044 \\
& -0.031
\end{aligned}
$$

0.031

0.027

0.15

\subsection{5}

0.26

\section{$-0.017$}

$-0.007$

0.031

0.031
0.042

-
0.57
0.88

0.096

0.039

0.015

Potatoes

consumption

- Low (ref)

$\begin{array}{cc}- & - \\ 0.022 & 0.043\end{array}$

0.60

0.046

0.46

$-0.001$

-
0.034
0.024

-
0.18
0.96

-
0.061
-0.036

$0 . \overline{-} 25$

0.029

0.016

- High

Fat consumption

- Low (ref)

- Medium

- High

$$
-0.029
$$

0.039

-

-

0.83

0.83
0.05

0.062

0.032

-
0.046
0.076

$\mathbf{0 . 0 4 6}$
$\mathbf{0 . 0 7 6}$

-
$\mathbf{0 . 0 3 1}$
$\mathbf{0 . 0 3 5}$

0.14

0.047
-0.005

0.055

0.042

0.40

Soft drinks

consumption

- Low (ref)

- Medium

$$
-0.012
$$

-
0.028

-
0.67
0.24
$-\overline{-0.037}$
$-\mathbf{0 . 1 2 0}$

-
$\mathbf{0 . 0 3 5}$
$\mathbf{0 . 0 3 6}$

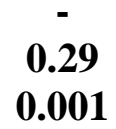

$-0.120$

0.033

0.043

$<0.001$

- High

$-0.033$

0.028

0.001

-
-0.035
-0.014

-
0.036
0.041

0.33

Water consumption

- Low (ref)

- Medium

$\begin{array}{cc}- & - \\ -0.023 & 0.032 \\ -0.035 & 0.036\end{array}$

0.48

$\begin{array}{cc}- & - \\ 0.063 & 0.040\end{array}$

0.11 0.036

0.57

$\begin{array}{ccc}- & - & - \\ 0.032 & 0.033 & 0.32 \\ 0.011 & 0.074 & 0.88\end{array}$




\section{Canada Food \\ Guide}

Vegetables and

fruits

- Not-meetin

$\begin{array}{lll}-0.011 & 0.044 & 0.81\end{array}$

0.81

0.037

0.062

0.55

$-0.141$

0.064

0.030

Grains

- Not-meeting

$-0.122$

0.249

0.63

$$
-0.019
$$

0.219

0.93

- Meeting

Milk

- Not-meeting

$-0.024$

0.020

0.23

$$
-0.021
$$

0.034

0.53

$-0.005$

0.044

0.91

- Meeting

心

Meats

- Not-meeting

$-0.062$

$\mathbf{0 . 0 3 0}$

0.038

0.006

0.025

0.82

0.014

0.028

0.62

- Meeting

\section{Mediterranean}

Diet

\section{Modified}

$-0.005$

0.007

0.43

0.0001

0.007

0.98

$-0.017$

0.008

0.043

Mediterranean Diet

N. B. Adjusted for age, sex, race, height, immigration status, marital status, education, income, BMI, smoking status, smoking exposure, alcohol drinker, current asthma, other respiratory diseases, family history of asthma, physical activity, and sedentary activity

Bold text indicates statistical significance 
Statistically significant $(\mathrm{p}<0.05)$ associations were observed between the $\mathrm{FEV}_{1} / \mathrm{FVC}$ ratio and the individual dietary variables including consumption of meats, milk, and fruits (Table 4.10).

- High consumption of meats was associated with higher $\mathrm{FEV}_{1} / \mathrm{FVC}$ (Cycle 3).

- Medium consumption of milk was associated with higher $\mathrm{FEV}_{1} / \mathrm{FVC}$ (Cycle 3).

- High consumption of fruits was associated with higher FEV $1 / \mathrm{FVC}$ (Cycle 2).

Within the Canada Food Guide, "not meeting" grains (Cycle 2) and meats (Cycle 1) requirements were statistically significant $(\mathrm{p}<0.05)$ and associated with lower $\mathrm{FEV}_{1} / \mathrm{FVC}$. There were no statistically significant associations observed within the modified Mediterranean Diet Score. 
Table 4.10 Multivariate analysis of dietary factors, Canada Food Guide, and modified Mediterranean Diet Score with FEV $1 /$ FVC ratio

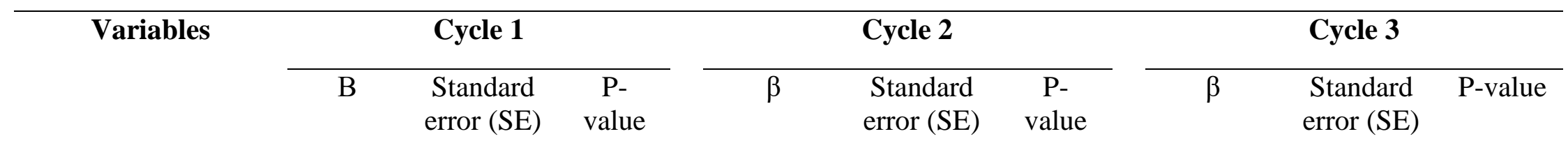

\section{Dietary}

Red meat consumption

- Low (ref)

- Medium

$-0.001$

0.005

0.

0.66

0.88

$-0.002$

0.006

$-0.003$

0.004

-
0.73
0.52

0.73
0.52

$\mathbf{0 . 0 0 3}$
$\mathbf{0 . 0 0 9}$

$\begin{array}{lc}- & - \\ \mathbf{0 . 0 0 4} & 0.57 \\ \mathbf{0 . 0 0 4} & \mathbf{0 . 0 3 2}\end{array}$

Fish consumption

- Low (ref)

- Medium

- High

$-0.008$

0.007

0.

0.005

0.08

$-0.004$

$-0.006$

-
0.004
0.005

0.33

0.33
0.25

$-0.008$

0.006

020

Egg consumption

- Low (ref)

- Medium

- High

0.003

0.004

0.005

0.61

-

Bean consumption

- Low (ref)

- Medium

- High

0.004

0.26

0.00004

0.005

$-0.007$

0.004

0.20
0.09

Milk consumption

- Low (ref)

- Medium

0.003

0.003

0.004

(1)

-
0.006
0.005

-
0.99

-
0.0001
-0.012

0.003

0.97

$0.005 \quad 0.88$

$-0.012$

0.007

0.10

- High

-
-0.002
-0.003

0.004
0.004

0.39

-
0.006
0.002

-
0.005
0.004

0.28
0.56

0.005

$-0.001$

0.003

0.18

0.42

0.002

0.004

0.005

0.90

$\begin{array}{cccccccc}- & - & - & - & - & - & - & - \\ 0.004 & 0.64 & -0.005 & 0.006 & 0.46 & \mathbf{0 . 0 1 3} & \mathbf{0 . 0 0 5} & \mathbf{0 . 0 0 4} \\ 0.003 & 0.34 & 0.0004 & 0.004 & 0.92 & \mathbf{0 . 0 0 5} & \mathbf{0 . 0 0 5} & \mathbf{0 . 3 8}\end{array}$




\begin{tabular}{|c|c|c|c|c|c|c|c|c|c|}
\hline $\begin{array}{c}\text { Grain consumption } \\
\text { - Low (ref) } \\
\text { - Medium } \\
\text { - High }\end{array}$ & $\begin{array}{c}- \\
0.001 \\
-0.006\end{array}$ & $\begin{array}{c}- \\
0.005 \\
0.005\end{array}$ & $\begin{array}{c}- \\
0.75 \\
0.25\end{array}$ & $\begin{array}{c}- \\
-0.004 \\
-0.001\end{array}$ & $\begin{array}{c}- \\
0.004 \\
0.003\end{array}$ & $\begin{array}{c}- \\
0.32 \\
0.73\end{array}$ & $\begin{array}{c}- \\
-0.002 \\
-0.001\end{array}$ & $\begin{array}{c}- \\
0.006 \\
0.005\end{array}$ & $\begin{array}{c}- \\
0.70 \\
0.90\end{array}$ \\
\hline $\begin{array}{c}\text { Fruit consumption } \\
\text { - Low (ref) } \\
\text { - Medium } \\
\text { - High }\end{array}$ & $\begin{array}{c}- \\
0.003 \\
0.001\end{array}$ & $\begin{array}{c}- \\
0.006 \\
0.005\end{array}$ & $\begin{array}{c}- \\
0.60 \\
0.86\end{array}$ & $\begin{array}{l}- \\
0.011 \\
0.013\end{array}$ & $\begin{array}{l}- \\
0.009 \\
0.005\end{array}$ & $\begin{array}{c}- \\
0.22 \\
0.013\end{array}$ & $\begin{array}{c}- \\
0.002 \\
0.007\end{array}$ & $\begin{array}{c}- \\
0.006 \\
0.005\end{array}$ & $\begin{array}{c}- \\
0.77 \\
0.17\end{array}$ \\
\hline $\begin{array}{l}\text { Vegetable } \\
\text { consumption } \\
\text { - Low (ref) } \\
\text { - Medium } \\
\text { - High }\end{array}$ & $\begin{array}{c}- \\
-0.005 \\
0.006\end{array}$ & $\begin{array}{c}- \\
0.005 \\
0.004\end{array}$ & $\begin{array}{l}- \\
0.25 \\
0.13\end{array}$ & $\begin{array}{c}- \\
-0.001 \\
0.002\end{array}$ & $\begin{array}{c}- \\
0.005 \\
0.004\end{array}$ & $\begin{array}{c}- \\
0.86 \\
0.64\end{array}$ & $\begin{array}{c}- \\
-0.003 \\
-0.005\end{array}$ & $\begin{array}{c}- \\
0.005 \\
0.005\end{array}$ & $\begin{array}{c}- \\
0.52 \\
0.26\end{array}$ \\
\hline $\begin{array}{l}\text { Potato consumption } \\
\text { - Low (ref) } \\
\text { - Medium } \\
\text { - High }\end{array}$ & $\begin{array}{c}- \\
0.005 \\
0.001\end{array}$ & $\begin{array}{c}- \\
0.003 \\
0.005\end{array}$ & $\begin{array}{c}- \\
0.12 \\
0.88\end{array}$ & $\begin{array}{c}- \\
0.004 \\
-0.004\end{array}$ & $\begin{array}{c}- \\
0.005 \\
0.004\end{array}$ & $\begin{array}{c}- \\
0.43 \\
0.31\end{array}$ & $\begin{array}{c}- \\
-0.008 \\
-0.007\end{array}$ & $\begin{array}{c}- \\
0.006 \\
0.005\end{array}$ & $\begin{array}{c}- \\
0.17 \\
0.22\end{array}$ \\
\hline $\begin{array}{c}\text { Fat consumption } \\
\text { - Low (ref) } \\
\text { - Medium } \\
\text { - High }\end{array}$ & $\begin{array}{c}- \\
-0.003 \\
-0.003\end{array}$ & $\begin{array}{c}- \\
0.005 \\
0.006\end{array}$ & $\begin{array}{l}- \\
0.56 \\
0.58\end{array}$ & $\begin{array}{c}- \\
-0.004 \\
-0.006\end{array}$ & $\begin{array}{c}- \\
0.005 \\
0.007\end{array}$ & $\begin{array}{c}- \\
0.48 \\
0.33\end{array}$ & $\begin{array}{c}- \\
0.003 \\
-0.001\end{array}$ & $\begin{array}{c}- \\
0.011 \\
0.007\end{array}$ & $\begin{array}{c}- \\
0.79 \\
0.91\end{array}$ \\
\hline $\begin{array}{l}\text { Soft drinks } \\
\text { consumption } \\
\text { - Low (ref) } \\
\text { - Medium } \\
\text { - High }\end{array}$ & $\begin{array}{c}- \\
0.003 \\
-0.002\end{array}$ & $\begin{array}{c}- \\
0.003 \\
0.005\end{array}$ & $\begin{array}{l}- \\
0.35 \\
0.73\end{array}$ & $\begin{array}{c}- \\
-0.004 \\
-0.003\end{array}$ & $\begin{array}{c}- \\
0.003 \\
0.004\end{array}$ & $\begin{array}{c}- \\
0.20 \\
0.49\end{array}$ & $\begin{array}{c}- \\
-0.005 \\
-0.001\end{array}$ & $\begin{array}{c}- \\
0.006 \\
0.007\end{array}$ & $\begin{array}{c}- \\
0.38 \\
0.84\end{array}$ \\
\hline $\begin{array}{c}\text { Water consumption } \\
\text { - Low (ref) } \\
\text { - Medium }\end{array}$ & $\begin{array}{c}- \\
-0.002\end{array}$ & $\begin{array}{c}- \\
0.003\end{array}$ & $\begin{array}{c}- \\
0.56\end{array}$ & $\begin{array}{c}- \\
0.006\end{array}$ & $\begin{array}{c}- \\
0.003\end{array}$ & $\begin{array}{c}- \\
0.05\end{array}$ & $\begin{array}{c}- \\
0.007\end{array}$ & $\stackrel{-}{0.006}$ & $\begin{array}{c}- \\
0.25\end{array}$ \\
\hline
\end{tabular}




\begin{tabular}{|c|c|c|c|c|c|c|c|c|c|}
\hline - High & -0.006 & 0.002 & 0.002 & -0.002 & 0.005 & 0.70 & 0.014 & 0.007 & 0.06 \\
\hline \multicolumn{10}{|l|}{$\begin{array}{l}\text { Canada Food } \\
\text { Guide }\end{array}$} \\
\hline \multicolumn{10}{|l|}{ Vegetables and fruits } \\
\hline - Not-meeting & -0.002 & 0.006 & 0.77 & -0.004 & 0.007 & 0.52 & -0.017 & 0.011 & 0.13 \\
\hline - Meeting & - & - & - & - & - & - & - & - & - \\
\hline \multicolumn{10}{|l|}{ Grains } \\
\hline - Not-meeting & 0.004 & 0.025 & 0.87 & -0.064 & 0.024 & 0.007 & - & - & - \\
\hline - Meeting & - & - & - & - & - & - & & & \\
\hline \multicolumn{10}{|l|}{ Milk } \\
\hline - Not-meeting & 0.001 & 0.004 & 0.76 & -0.002 & 0.005 & 0.71 & 0.005 & 0.006 & 0.36 \\
\hline - Meeting & - & - & - & - & - & - & - & - & - \\
\hline \multicolumn{10}{|l|}{ Meats } \\
\hline - Not-meeting & -0.008 & 0.004 & 0.031 & 0.003 & 0.005 & 0.63 & 0.003 & 0.005 & 0.51 \\
\hline - Meeting & - & - & - & - & - & - & - & - & - \\
\hline \multicolumn{10}{|l|}{ Mediterranean Diet } \\
\hline $\begin{array}{l}\text { Modified } \\
\text { Mediterranean Diet } \\
\text { Score }\end{array}$ & -0.001 & 0.001 & 0.65 & -0.001 & 0.001 & 0.52 & -0.001 & 0.001 & 0.30 \\
\hline
\end{tabular}

N. B. Adjusted for age, sex, race, height, immigration status, marital status, education, income, BMI, smoking status, smoking exposure, alcohol drinker, current asthma, other respiratory diseases, family history of asthma, physical activity, and sedentary activity

Bold text indicates statistical significance 
Statistically significant $(\mathrm{p}<0.05)$ associations were observed between the $\mathrm{FEF}_{25-75 \%}$ and the individual dietary variables including consumption of meats, eggs, milk, fruits, potatoes, and soft drinks (Table 4.11).

- High consumption of meats was associated with higher $\mathrm{FEF}_{25-75 \%}$ (Cycle 3).

- High consumption of eggs was associated with higher $\mathrm{FEF}_{25-75 \%}$ (Cycle 1).

- Medium consumption of milk was associated with higher $\mathrm{FEF}_{25-75 \%}$ (Cycle 3).

- High consumption of fruits was associated with higher $\mathrm{FEF}_{25-75 \%}$ (Cycle 2).

- Medium and high consumption of potatoes was associated with lower $\mathrm{FEF}_{25-75 \%}$ (Cycle 3).

- High consumption of soft drinks was associated with lower $\mathrm{FEF}_{25-75 \%}$ (Cycle 2).

Within the Canada Food Guide, only "not meeting" the meats (Cycle 1) requirement were statistically significant $(\mathrm{p}<0.05)$ and associated with lower $\mathrm{FEF}_{25-75 \%}$. There were no statistically significant associations observed with the modified Mediterranean Diet Score. 
Table 4.11 Multivariate analysis of dietary factors, Canada Food Guide, and modified Mediterranean Diet Score with FEF $25-75 \%$

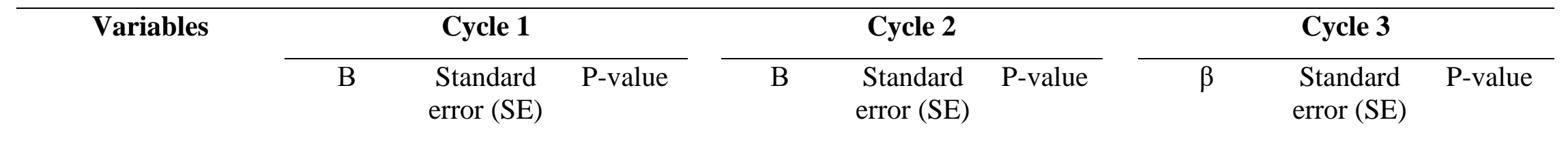

\section{Dietary}

Red meat consumption

- Low (ref)

- Medium

- High

Fish consumption

- Low (ref)

- Medium

- High

$$
-0.070
$$

$-0.127$

-
0.089
0.070

0.43

0.43

0.07

$$
\begin{gathered}
-0.037 \\
0.006
\end{gathered}
$$

0.055
0.056

0.50

0.91

-0.054
-0.028

0.083

0.060

0.51

Eggs consumption

- Low (ref)

- Medium

- High

$\mathbf{0 . 0 2 3}$

0.104

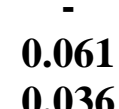

0.

0.71
0.004

0.003

0.021

0.063

0.070

0.96

0.76

0.061

$-0.104$

0.050

0.093

0.22

Beans consumption

- Low (ref)

- Medium

- High

0.077

0.077
0.088

0.047

-

0.10

0.035

$-0.066$

0.075

0.075
0.057

0.64

0.25

0.074
0.060

0.056

0.072

0.18

Milk consumption

- Low (ref)

- Medium

$-$

$-0.002$

-
0.067
0.028

0.97

0.35

-
0.010
-0.013

$-0.013$

-
0.058
0.047

0.058
0.047

0.86

0.86
0.78

-
$\mathbf{0 . 1 7 5}$
$\mathbf{0 . 0 1 8}$

-
0.062
0.080

0.82




\begin{tabular}{|c|c|c|c|c|c|c|c|c|c|}
\hline \multicolumn{10}{|l|}{ Grains consumption } \\
\hline - Low (ref) & $-\overline{-}$ & $0 . \overline{-}$ & $\begin{array}{c}- \\
0.93\end{array}$ & $\overline{-} .011$ & $0 . \overline{0} 0$ & $\overline{-} \cdot \overline{8}$ & $0 . \overline{-}$ & $0 . \overline{-}$ & $\overline{0 .}$ \\
\hline - High & -0.092 & 0.066 & 0.16 & 0.035 & 0.040 & 0.37 & 0.036 & 0.063 & 0.57 \\
\hline \multicolumn{10}{|l|}{ Fruits consumption } \\
\hline - Low (ref) & - & - & - & - & - & - & - & - & - \\
\hline - Medium & -0.015 & 0.072 & 0.83 & 0.168 & 0.140 & 0.23 & -0.002 & 0.082 & 0.98 \\
\hline - High & -0.002 & 0.063 & 0.97 & 0.125 & 0.056 & 0.026 & 0.103 & 0.067 & 0.13 \\
\hline \multicolumn{10}{|l|}{ Vegetables } \\
\hline - Low (ref) & -0.102 & 0.059 & 0.08 & -0.042 & 0.067 & 0.53 & 0.029 & 0.056 & 0.60 \\
\hline - Medium & -0.0004 & 0.059 & 0.99 & -0.052 & 0.068 & 0.44 & -0.051 & 0.054 & 0.34 \\
\hline - High & & & & & & & & & \\
\hline \multicolumn{10}{|l|}{ Potato consumption } \\
\hline - Low (ref) & - & - & - & - & - & - & - & - & - \\
\hline - Medium & 0.134 & 0.075 & 0.08 & 0.095 & 0.070 & 0.17 & -0.183 & 0.062 & 0.003 \\
\hline - High & 0.051 & 0.063 & 0.42 & -0.025 & 0.036 & 0.49 & -0.136 & 0.055 & 0.014 \\
\hline \multicolumn{10}{|l|}{ Fat consumption } \\
\hline - Low (ref) & - & - & - & - & - & - & - & - & - \\
\hline - Medium & -0.062 & 0.054 & 0.25 & 0.039 & 0.047 & 0.41 & 0.081 & 0.119 & 0.50 \\
\hline - High & -0.016 & 0.055 & 0.78 & 0.015 & 0.054 & 0.79 & -0.040 & 0.072 & 0.58 \\
\hline \multicolumn{10}{|l|}{$\begin{array}{l}\text { Soft drinks } \\
\text { consumption }\end{array}$} \\
\hline - Low (ref) & - & - & - & - & - & - & - & - & - \\
\hline - Medium & 0.005 & 0.044 & 0.91 & -0.074 & 0.042 & 0.08 & -0.094 & 0.074 & 0.20 \\
\hline - High & -0.064 & 0.058 & 0.27 & -0.144 & 0.059 & 0.015 & 0.030 & 0.083 & 0.72 \\
\hline \multicolumn{10}{|l|}{ Water consumption } \\
\hline - Low (ref) & - & - & - & - & - & - & - & - & - \\
\hline - Medium & -0.064 & 0.036 & 0.08 & 0.156 & $\mathbf{0 . 0 6 0}$ & 0.009 & 0.059 & 0.059 & 0.31 \\
\hline - High & -0.135 & 0.035 & $<0.001$ & 0.059 & 0.072 & 0.41 & 0.104 & 0.109 & 0.34 \\
\hline
\end{tabular}




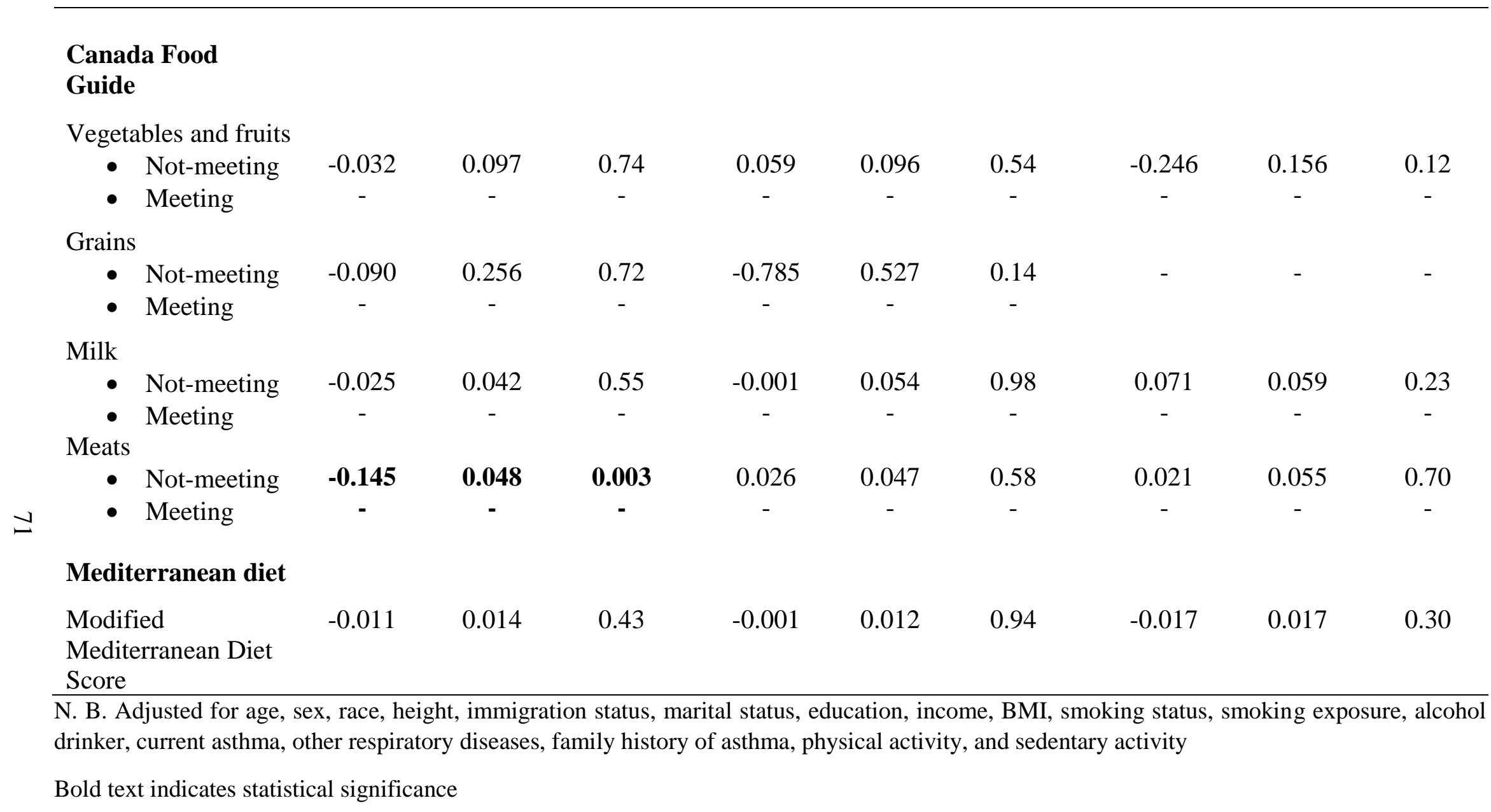




\subsection{Biomarkers}

Tables 4.12, 4.13, 4.14, and 4.15 show the relationship between biomarkers with the four outcome variables of lung function ( $\mathrm{FVC}, \mathrm{FEV}_{1}, \mathrm{FEV}_{1} / \mathrm{FVC}$ ratio, and $\mathrm{FEF}_{25-75 \%}$, respectively).

For the outcome FVC (Table 4.12), associations with chloride (Cycles 1, 2, 3), potassium (Cycle 2), C-reactive protein (Cycles 1, 3), total protein (Cycle 2), and Vitamin B12 (Cycle 3) were statistically significant $(\mathrm{p}<0.05)$.

- The chloride levels were associated with higher FVC (Cycles 1, 2, 3).

- The potassium levels were associated with lower FVC (Cycle 2).

- $\quad$ The C-reactive protein levels were associated with lower FVC (Cycles 1, 3).

- The total protein levels were associated with lower FVC (Cycle 2).

- The Vitamin B12 levels were associated with lower FVC (Cycle 3). 
Table 4.12 Multivariate analysis of biomarkers with FVC

\begin{tabular}{|c|c|c|c|c|c|c|c|c|c|}
\hline \multirow[t]{2}{*}{ Variables } & \multicolumn{3}{|c|}{ Cycle 1} & \multicolumn{3}{|c|}{ Cycle 2} & \multicolumn{3}{|c|}{ Cycle 3} \\
\hline & $\mathrm{B}$ & $\begin{array}{l}\text { Standard } \\
\text { error } \\
(\mathrm{SE})\end{array}$ & P-value & $\beta$ & $\begin{array}{c}\text { Standard } \\
\text { error } \\
(\mathrm{SE})\end{array}$ & $\mathrm{P}$-value & $\beta$ & $\begin{array}{c}\text { Standard } \\
\text { error }(\mathrm{SE})\end{array}$ & $\mathrm{P}$-value \\
\hline \multicolumn{10}{|l|}{ Biomarkers } \\
\hline Vitamin D (nmol/L) & 0.002 & 0.001 & 0.06 & 0.001 & 0.001 & 0.16 & 0.002 & 0.001 & 0.12 \\
\hline Chloride (mmol/L) & 0.008 & 0.004 & 0.022 & 0.026 & 0.009 & 0.002 & 0.031 & 0.014 & 0.023 \\
\hline Potassium (mmol/L) & -0.069 & 0.036 & 0.05 & -0.128 & 0.046 & 0.006 & -0.028 & 0.052 & 0.59 \\
\hline $\begin{array}{l}\text { C-reactive protein } \\
(\mathrm{mg} / \mathrm{L})\end{array}$ & -0.037 & 0.004 & $<0.001$ & -0.014 & 0.010 & 0.17 & -0.027 & 0.007 & $<0.001$ \\
\hline Total protein $(\mathrm{g} / \mathrm{L})$ & 0.002 & 0.006 & 0.71 & -0.010 & 0.004 & 0.009 & 0.008 & 0.008 & 0.29 \\
\hline Sodium (mmol/L) & -0.004 & 0.009 & 0.67 & -0.006 & 0.012 & 0.63 & -0.019 & 0.021 & 0.36 \\
\hline Calcium (mmol/L) & 0.244 & 0.186 & 0.19 & 0.344 & 0.220 & 0.12 & 0.323 & 0.352 & 0.36 \\
\hline $\begin{array}{l}\text { High density } \\
\text { lipoprotein (HDL) } \\
(\mathrm{mmol} / \mathrm{L})\end{array}$ & 0.105 & 0.067 & 0.12 & 0.061 & 0.047 & 0.19 & 0.023 & 0.078 & 0.77 \\
\hline $\begin{array}{l}\text { Total cholesterol } \\
(\mathrm{mmol} / \mathrm{L})\end{array}$ & 0.012 & 0.015 & 0.42 & 0.026 & 0.031 & 0.40 & -0.003 & 0.022 & 0.87 \\
\hline $\begin{array}{l}\text { Red blood cell folate } \\
(\mathrm{nmol} / \mathrm{L})\end{array}$ & 0.00001 & 0.00002 & 0.46 & -0.00004 & 0.00004 & 0.28 & 0.0001 & 0.0001 & 0.11 \\
\hline Vitamin B12 (pmol/L) & -0.0001 & 0.0002 & 0.39 & 0.0001 & 0.0001 & 0.43 & -0.0002 & 0.0001 & 0.044 \\
\hline
\end{tabular}

N. B. Adjusted for age, sex, race, height, immigration status, marital status, education, income, BMI, smoking status, smoking exposure, alcohol drinker, current asthma, other respiratory diseases, family history of asthma, physical activity, and sedentary activity

Bold text indicates statistical significance 
For the outcome $\mathrm{FEV}_{1}$ (Table 4.13), associations with Vitamin D (Cycles 1, 3), chloride (Cycles 1, 2, 3), potassium (Cycle 2), C-reactive protein (Cycles 1, 3), calcium (Cycle 2), red blood cell folate (Cycle 3), and Vitamin B12 (Cycles 1, 3) were statistically significant ( $<<0.05)$.

- The Vitamin D levels were associated with higher FEV 1 (Cycles 1, 3).

- The chloride levels were associated with higher FEV 1 (Cycles 1, 2, 3).

- The potassium levels were associated with lower $\mathrm{FEV}_{1}$ (Cycle 2).

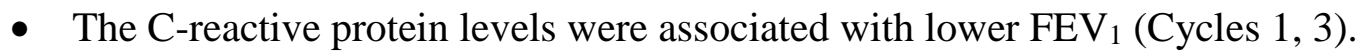

- The calcium levels were associated with higher FEV 1 (Cycle 2).

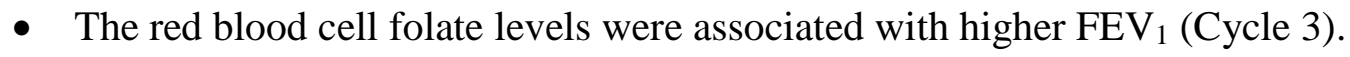

- The Vitamin B12 levels were associated with lower FEV 1 (Cycle 1, 3). 
Table 4.13 Multivariate analysis of biomarkers with $\mathrm{FEV}_{1}$

\begin{tabular}{|c|c|c|c|c|c|c|c|c|c|}
\hline \multirow[t]{2}{*}{ Variables } & \multicolumn{3}{|c|}{ Cycle 1} & \multicolumn{3}{|c|}{ Cycle 2} & \multicolumn{3}{|c|}{ Cycle 3} \\
\hline & $\mathrm{B}$ & $\begin{array}{c}\text { Standard } \\
\text { error } \\
(\mathrm{SE})\end{array}$ & $\begin{array}{c}\mathrm{P}- \\
\text { value }\end{array}$ & $\beta$ & $\begin{array}{c}\text { Standard } \\
\text { error } \\
(\mathrm{SE}) \\
\end{array}$ & $\begin{array}{c}\mathrm{P}- \\
\text { value }\end{array}$ & $\beta$ & $\begin{array}{c}\text { Standard } \\
\text { error } \\
(\mathrm{SE}) \\
\end{array}$ & $\begin{array}{c}\mathrm{P}- \\
\text { value }\end{array}$ \\
\hline \multicolumn{10}{|l|}{ Biomarkers } \\
\hline Vitamin D (nmol/L) & 0.001 & 0.001 & 0.007 & 0.001 & 0.0005 & 0.17 & 0.002 & 0.001 & 0.048 \\
\hline Chloride (mmol/L) & 0.013 & 0.006 & 0.046 & 0.022 & 0.008 & 0.006 & $\mathbf{0 . 0 2 7}$ & 0.009 & 0.004 \\
\hline Potassium (mmol/L) & -0.089 & 0.053 & 0.09 & -0.090 & 0.038 & 0.018 & -0.050 & 0.050 & 0.32 \\
\hline C-reactive protein $(\mathrm{mg} / \mathrm{L})$ & -0.032 & 0.003 & $<0.001$ & -0.011 & 0.010 & 0.28 & $-\mathbf{0 . 0 3 3}$ & 0.007 & $<0.001$ \\
\hline Total protein $(\mathrm{g} / \mathrm{L})$ & 0.005 & 0.006 & 0.43 & -0.005 & 0.004 & 0.13 & 0.011 & 0.006 & 0.07 \\
\hline Sodium (mmol/L) & -0.008 & 0.007 & 0.21 & -0.012 & 0.010 & 0.27 & -0.009 & 0.013 & 0.48 \\
\hline Calcium (mmol/L) & 0.139 & 0.161 & 0.39 & 0.527 & 0.164 & 0.001 & -0.013 & 0.276 & 0.96 \\
\hline $\begin{array}{l}\text { High density lipoprotein } \\
\text { (HDL) (mmol/L) }\end{array}$ & 0.061 & 0.051 & 0.23 & 0.005 & 0.027 & 0.86 & -0.013 & 0.071 & 0.86 \\
\hline $\begin{array}{l}\text { Total cholesterol } \\
(\mathrm{mmol} / \mathrm{L})\end{array}$ & 0.015 & 0.018 & 0.41 & 0.018 & 0.021 & 0.40 & 0.001 & 0.020 & 0.97 \\
\hline $\begin{array}{l}\text { Red blood cell folate } \\
\text { (nmol/L) }\end{array}$ & $-7.80 \mathrm{e}-06$ & 0.00002 & 0.63 & -0.00003 & 0.00003 & 0.18 & 0.0001 & 0.0001 & 0.047 \\
\hline Vitamin B12 (pmol/L) & -0.0002 & 0.0001 & 0.009 & -0.00005 & 0.0001 & 0.60 & -0.0002 & 0.0001 & 0.006 \\
\hline
\end{tabular}

N. B. Adjusted for age, sex, race, height, immigration status, marital status, education, income, BMI, smoking status, smoking exposure, alcohol drinker, current asthma, other respiratory diseases, family history of asthma, physical activity, and sedentary activity

Bold text indicates statistical significance 
For the outcome $\mathrm{FEV}_{1} / \mathrm{FVC}$ ratio (Table 4.14), associations with Vitamin D (Cycle 3), calcium (Cycle 3), red blood cell folate (cycle 2), and Vitamin B12 (Cycle 2) were statistically significant $(\mathrm{p}<0.05)$.

- The Vitamin D levels were associated with lower $\mathrm{FEV}_{1} / \mathrm{FVC}$ ratio (Cycle 3).

- $\quad$ The calcium levels were associated with higher $\mathrm{FEV}_{1} / \mathrm{FVC}$ ratio (Cycle 3).

- The red blood cell folate levels were associated with lower $\mathrm{FEV}_{1} / \mathrm{FVC}$ ratio (Cycle 2).

- The Vitamin B12 levels were associated with higher $\mathrm{FEV}_{1} / \mathrm{FVC}$ ratio (Cycle 2). 
Table 4.14 Multivariate analysis of biomarkers with $\mathrm{FEV}_{1} / \mathrm{FVC}$ ratio

\begin{tabular}{|c|c|c|c|c|c|c|c|c|c|}
\hline \multirow[t]{2}{*}{ Variables } & \multicolumn{3}{|c|}{ Cycle 1} & \multicolumn{3}{|c|}{ Cycle 2} & \multicolumn{3}{|c|}{ Cycle 3} \\
\hline & $\mathrm{B}$ & $\begin{array}{c}\text { Standard } \\
\text { error } \\
(\mathrm{SE})\end{array}$ & $\begin{array}{c}\mathrm{P}- \\
\text { value }\end{array}$ & $\beta$ & $\begin{array}{c}\text { Standard } \\
\text { error } \\
\text { (SE) }\end{array}$ & $\begin{array}{c}\mathrm{P}- \\
\text { value }\end{array}$ & $\beta$ & $\begin{array}{c}\text { Standard } \\
\text { error } \\
(\mathrm{SE})\end{array}$ & $\begin{array}{c}\mathrm{P}- \\
\text { value }\end{array}$ \\
\hline \multicolumn{10}{|l|}{ Biomarkers } \\
\hline Chloride (mmol/L) & 0.00005 & 0.00005 & 0.33 & $3.48 \mathrm{e}-06$ & 0.00002 & 0.87 & $-9.58 \mathrm{e}-06$ & 0.00001 & 0.38 \\
\hline Potassium (mmol/L) & 0.0001 & 0.0001 & 0.19 & 0.00005 & 0.0001 & 0.33 & 0.0001 & 0.00007 & 0.28 \\
\hline C-reactive protein $(\mathrm{mg} / \mathrm{L})$ & 0.002 & 0.001 & 0.07 & 0.003 & 0.002 & 0.12 & 0.002 & 0.002 & 0.29 \\
\hline $\begin{array}{l}\text { High density lipoprotein } \\
(\mathrm{HDL})(\mathrm{mmol} / \mathrm{L})\end{array}$ & 0.0001 & 0.0003 & 0.73 & 0.0004 & 0.0003 & 0.21 & -0.001 & 0.0004 & 0.06 \\
\hline Total cholesterol (mmol/L) & $4.49 \mathrm{e}-06$ & $6.12 \mathrm{e}-06$ & 0.46 & $6.23 e-06$ & 0.00002 & 0.74 & $6.89 \mathrm{e}-06$ & 0.00002 & 0.66 \\
\hline $\begin{array}{l}\text { Red blood cell folate } \\
(\mathrm{nmol} / \mathrm{L})\end{array}$ & -0.002 & 0.001 & 0.21 & -0.003 & 0.001 & 0.031 & 0.001 & 0.002 & 0.56 \\
\hline Vitamin B12 (pmol/L) & -0.010 & 0.016 & 0.53 & 0.087 & 0.029 & 0.003 & -0.071 & 0.041 & 0.08 \\
\hline
\end{tabular}

N. B. Adjusted for age, sex, race, height, immigration status, marital status, education, income, BMI, smoking status, smoking exposure, alcohol drinker, current asthma, other respiratory diseases, family history of asthma, physical activity, and sedentary activity

Bold text indicates statistical significance 
For the outcome $\mathrm{FEF}_{25-75 \%}$ (Table 4.15), associations with Vitamin D (Cycle 1), chloride (Cycle 2), C-reactive protein (Cycles 1, 3), total protein (Cycle 3), sodium (Cycle 2), calcium (Cycle 2), and Vitamin B12 (Cycle 1) were statistically significant $(\mathrm{p}<0.05)$.

- The Vitamin D levels were associated with higher $\mathrm{FEF}_{25-75 \%}(\mathrm{Cycle} 1)$.

- $\quad$ The chloride levels were associated with higher $\mathrm{FEF}_{25-75 \%}$ (Cycle 2).

- $\quad$ The C-reactive protein levels were associated with lower $\mathrm{FEF}_{25-75 \%}$ (Cycles 1, 3).

- The total protein levels were associated with higher $\mathrm{FEF}_{25-75 \%}$ (Cycle 3).

- The sodium levels were associated with lower $\mathrm{FEF}_{25-75 \%}$ (Cycle 2).

- The calcium levels were associated with higher $\mathrm{FEF}_{25-75 \%}$ (Cycle 2).

- The Vitamin B12 levels were associated with lower $\mathrm{FEF}_{25-75 \%}$ (Cycle 1). 
Table 4.15 Multivariate analysis of biomarkers with $\mathrm{FEF}_{25-75 \%}$

\begin{tabular}{|c|c|c|c|c|c|c|c|c|c|}
\hline \multirow[t]{2}{*}{ Variables } & \multicolumn{3}{|c|}{ Cycle 1} & \multicolumn{3}{|c|}{ Cycle 2} & \multicolumn{3}{|c|}{ Cycle 3} \\
\hline & $\mathrm{B}$ & $\begin{array}{c}\text { Standard } \\
\text { error } \\
(\mathrm{SE})\end{array}$ & $\begin{array}{c}\mathrm{P}- \\
\text { value }\end{array}$ & $\beta$ & $\begin{array}{c}\text { Standard } \\
\text { error } \\
(\mathrm{SE})\end{array}$ & $\begin{array}{c}\mathrm{P}- \\
\text { value }\end{array}$ & $\beta$ & $\begin{array}{l}\text { Stand } \\
\text { ard } \\
\text { error } \\
(\mathrm{SE})\end{array}$ & P-value \\
\hline \multicolumn{10}{|l|}{ Biomarkers } \\
\hline Vitamin D (nmol/L) & 0.002 & 0.001 & 0.036 & 0.00002 & 0.001 & 0.97 & 0.001 & 0.001 & 0.47 \\
\hline Chloride (mmol/L) & 0.016 & 0.017 & 0.35 & 0.028 & 0.013 & 0.034 & 0.034 & 0.022 & 0.12 \\
\hline Potassium (mmol/L) & -0.067 & 0.141 & 0.64 & -0.069 & 0.098 & 0.49 & -0.100 & 0.109 & 0.36 \\
\hline C-reactive protein $(\mathrm{mg} / \mathrm{L})$ & -0.034 & 0.008 & $<0.001$ & -0.020 & 0.017 & 0.22 & -0.046 & 0.011 & $<0.001$ \\
\hline Total protein $(\mathrm{g} / \mathrm{L})$ & 0.010 & 0.011 & 0.34 & 0.001 & 0.007 & 0.91 & 0.026 & 0.006 & $<0.001$ \\
\hline Sodium (mmol/L) & -0.013 & 0.019 & 0.49 & -0.034 & 0.014 & 0.012 & -0.002 & 0.018 & 0.91 \\
\hline Calcium (mmol/L) & -0.094 & 0.164 & 0.57 & 1.034 & 0.266 & $<0.001$ & -0.564 & 0.392 & 0.15 \\
\hline $\begin{array}{l}\text { High density lipoprotein } \\
\text { (HDL) (mmol/L) }\end{array}$ & -0.013 & 0.077 & 0.86 & -0.113 & 0.058 & 0.05 & -0.033 & 0.094 & 0.73 \\
\hline Total cholesterol (mmol/L) & 0.045 & 0.045 & 0.32 & 0.018 & 0.023 & 0.43 & 0.001 & 0.037 & 0.97 \\
\hline $\begin{array}{l}\text { Red blood cell folate } \\
(\mathrm{nmol} / \mathrm{L})\end{array}$ & -0.00004 & 0.00004 & 0.34 & -0.0001 & 0.00005 & 0.11 & 0.0001 & $\begin{array}{c}0.000 \\
1\end{array}$ & 0.27 \\
\hline Vitamin B12 (pmol/L) & -0.0004 & 0.0002 & 0.027 & -0.0002 & 0.0002 & 0.32 & -0.0002 & $\begin{array}{c}0.000 \\
1 \\
\end{array}$ & 0.07 \\
\hline
\end{tabular}

N. B. Adjusted for age, sex, race, height, immigration status, marital status, education, income, BMI, smoking status, smoking exposure, alcohol drinker, current asthma, other respiratory diseases, family history of asthma, physical activity, and sedentary activity

Bold text indicates statistical significance 


\subsection{Assessment of effect modification}

The effect modification between dietary factors and asthma was tested. Some effect modification was found to be statistically significant (Table 4.16). However, the inclusion of the interaction term to the model caused the model to become unstable (bootstrapping could not replicate enough times for the convergence of the model). Therefore, interaction terms were excluded from further evaluation. The effect modification between dietary factors and COPD was not tested because there were not enough observations $(<1 \%)$ of COPD to meet the criteria of minimum observations required by Statistics Canada.

Table 4.16 List of significant interaction terms Cycle by Cycle

\begin{tabular}{|c|c|c|c|}
\hline Lung function & Cycle 1 & Cycle 2 & Cycle 3 \\
\hline FVC & asthma_c*pot1 & $\begin{array}{c}\text { asthma_c*f1 } \\
\text { asthma_c*f2 } \\
\text { asthma_c*pot2 }\end{array}$ & $\begin{array}{l}\text { asthma_c*f3 } \\
\text { asthma_c*veg2 } \\
\text { asthma_c*pot1 } \\
\text { asthma_c*sf1 } \\
\text { asthma_c*sf3 } \\
\text { asthma_c*w2 }\end{array}$ \\
\hline $\mathrm{FEV}_{1}$ & $\begin{array}{l}\text { asthma_c*gr1 } \\
\text { asthma_c*gr2 } \\
\text { asthma_c*frt1 }\end{array}$ & $\begin{array}{l}\text { asthma_c*f2 } \\
\text { asthma_c*veg1 } \\
\text { asthma_c*sf1 }\end{array}$ & $\begin{array}{l}\text { asthma_c*f3 } \\
\text { asthma_c*pot1 } \\
\text { asthma_c*sf } 1\end{array}$ \\
\hline $\mathrm{FEV}_{1} / \mathrm{FVC}$ ratio & $\begin{array}{l}\text { asthma_c*egg3 } \\
\text { asthma_c*gr1 }\end{array}$ & $\begin{array}{l}\text { asthma_c*m3 } \\
\text { asthma_c*sf1 }\end{array}$ & asthma_c*m2 \\
\hline $\mathrm{FEF}_{25-75 \%}$ & asthma_c*egg3 & $\begin{array}{l}\text { asthma_c*m3 } \\
\text { asthma_c*f2 } \\
\text { asthma_c*sf1 }\end{array}$ & $\begin{array}{l}\text { asthma_c*m2 } \\
\text { asthma_c*f3 }\end{array}$ \\
\hline
\end{tabular}

Current asthma $=$ asthma_c

Meats (low, medium, high tertile) $=\mathrm{m} 1, \mathrm{~m} 2, \mathrm{~m} 3$

Fishes (low, medium, high tertile $)=f 1, f 2, f 3$

Potatoes (low, medium, high tertile $)=\operatorname{pot} 1, \operatorname{pot} 2, \operatorname{pot} 3$

Vegetables (low, medium, high tertile) = veg1, veg2, veg3

Grains (low, medium, high tertile) = gr1, gr2, gr3 
Eggs (low, medium, high tertile $)=$ egg1, egg2, egg3

Fruits (low, medium, high tertile $)=$ frt 1, frt 2, frt 3

Soft drinks (low, medium, high tertile) $=\mathrm{sf} 1, \mathrm{sf} 2, \mathrm{sf} 3$

Water (low, medium, high tertile $)=w 1, w 2, w 3$ 


\section{Chapter 5 : Discussion}

\subsection{Summary}

The purpose of this thesis was to explore lung function status and its association with dietary factors among Canadian adults (18-79 years). The Canadian Health Measures Survey (CHMS) was a repeated cross-sectional survey with health assessments and an excellent source for obtaining information regarding the demographics, dietary factors, biomarkers, and spirometry from a representative sample of Canadian adults. Below, the findings of this thesis are summarized. Following this summary, a more in-depth discussion of the results is provided. A full results summary by food group is located in Appendix 4.

Research question 1: What are the characteristics/status of lung function ( $\mathrm{FEV}_{1}, \mathrm{FVC}, \mathrm{FEV}_{1} / \mathrm{FVC}$ ratio, and $\left.\mathrm{FEF}_{25-75 \%}\right)$ in Canadian adults (18-79 years)?

- On average, the percent predicted mean for FVC was approximately $98 \%, \mathrm{FEV}_{1}$ was approximately $95.5 \%$, and the absolute $\mathrm{FEV}_{1} / \mathrm{FVC}$ ratio was approximately 0.78 (overall in Cycles 1, 2, and 3). These values suggest good lung function of the overall general population.

- As expected, the lung function decreased gradually from the younger adults to the older adults (e.g. in Cycle 1, FVC: $100.9 \%$ vs. $97.4 \%$ vs. $96.1 \%$ ).

Research question 2. A: Are dietary factors (e.g. food types), dietary patterns (e.g. Mediterranean Diet), or biomarkers associated with lung function levels based on spirometry in a nationally representative Canadian population of adults?

Research question 2. B: Is there effect modification between dietary factors and asthma or COPD in the relationship with lung function? 


\section{Individual food, Canada Food Guide, and Mediterranean Diet Score:}

- The associations between the exposure of interest (dietary consumption of individual food, Canada Food Guide, and Mediterranean Diet Score) and the outcome (lung function: FEV 1 , $\mathrm{FVC}, \mathrm{FEV}_{1} / \mathrm{FVC}$ ratio, and $\mathrm{FEF}_{25-75 \%}$ ) were somewhat inconsistent by Cycle, food group, and outcome.

- While inconsistent, general findings suggest that dietary fat was associated with higher lung function among the individual food groups. Not meeting the Canada Food Guide requirements was associated with lower lung function. Modified Mediterranean Diet Score was associated with lower lung function.

\section{Biomarkers:}

- The association between biomarkers and lung function were more consistent than food consumption throughout the Cycles.

- Among the more consistent associations for biomarkers, chloride was associated with higher $\mathrm{FVC}$ and $\mathrm{FEV}_{1}$ for all three Cycles $(\mathrm{p}<0.05)$. C-reactive protein was associated with lower FVC, FEV 1 , and $\mathrm{FEF}_{25-75 \%}($ Cycles 1 and 3. p<0.05). Vitamin D was associated with higher FEV 1 (Cycles 1 and 3. p<0.05). Finally, Vitamin B12 was associated with lower $\mathrm{FEV}_{1}($ Cycles 1 and 3. $\mathrm{p}<0.05)$.

\section{Effect modification between dietary factors and asthma or COPD}

Some effect modification was found to be statistically significant. However, the inclusion of the interaction term to the model caused the model to become unstable (bootstrapping could not replicate enough times for the convergence of the model). Therefore, interaction terms were excluded from further evaluation. 


\subsection{Comparing findings with the previous studies}

\subsubsection{Individual food consumption and lung function}

\section{$\underline{\text { Red meats }}$}

A study conducted in 2014 in the UK among adults (Hertfordshire cohort study) showed that processed meat consumption had been associated with lower $\mathrm{FVC}, \mathrm{FEV}_{1}$, and the $\mathrm{FEV}_{1} / \mathrm{FVC}$ ratio (140). Another study conducted in 2007 in the U.S among adults aged 45 years or older (The Third National Health and Nutrition Examination Survey (NHANES III)) also showed that cured meat consumption had been associated with lower $\mathrm{FEV}_{1}$ and the $\mathrm{FEV}_{1} / \mathrm{FVC}$ ratio (84). Results from the current study, which included overall red meat consumption, indicated that meat is associated with higher $\mathrm{FEV}_{1} / \mathrm{FVC}(\mathrm{p}<0.05)$ and higher $\mathrm{FEF}_{25-75 \%}(\mathrm{p}<0.05)$ but only in Cycle 3. We did not classify the meat type neither "processed" vs "not processed" nor included "chicken meat" within the total meat consumption as this information was not available, which may lead to differences between ours and the previous studies.

\section{$\underline{\text { Fish }}$}

The association between the consumption of fish and lung function in previous studies has not been consistent $(85,88)$. A cross-sectional study conducted in 1994 in the U.S among adults (aged 30-70 years) (The First National Health and Nutrition Examination Survey (NHANES I)) showed that consumption of fish was associated with higher $\mathrm{FEV}_{1}(88)$. In a prospective study conducted in 2000 among men (aged 45-59 years) it was shown that the frequency of fatty fish intake was not significantly associated with lung function (85). In our study, no statistically significant association was observed between fish consumption and lung function. We included all fish consumption (total fish consumption including shellfish) together as a single variable instead of separating as fatty and non-fatty fish and also, used a wide range of age (18-79 years) which might cause the non-significant association in results. 


\section{$\underline{\text { Grains }}$}

A study in 2001 in the Netherlands among adults (20-59 years) reported that consumption of whole grains was associated with higher $\mathrm{FEV}_{1}(22)$. The current study supports this result to some degree. In Cycle 3, medium consumption of grains was associated with higher FVC and higher $\mathrm{FEV}_{1}$. Grains are mostly carbohydrate rich food. Higher consumption of carbohydrate may lead to overweight and obesity $(141,142)$ while lower grain consumption or low carbohydrate has been associated with all-cause mortality and may be unsafe for health (143). Obesity has been considered as a predisposing factor for asthma (144). Either higher or lower consumption of grains could be detrimental to lung health. This could, therefore, explain why medium consumption of grains could be beneficial for lung function.

\section{$\underline{\text { Fruits }}$}

A study conducted in 1998 among adult residents of England, Scotland, and Wales (87) and another study in 2001 in the Netherlands among adults (20-59 years) (22) showed that consumption of fruits was associated with higher $\mathrm{FEV}_{1}$. In the current study, high consumption of fruits was associated with higher $\mathrm{FEV}_{1}(\mathrm{Cycle} 3), \mathrm{FEV}_{1} / \mathrm{FVC}$ ratio (Cycle 2), and $\mathrm{FEF}_{25-75 \%}(\mathrm{Cycle}$ 2). As such, the current results support the previous research.

\section{$\underline{\text { Vegetables }}$}

Again, in 2001 in the Netherlands among adults (20-59 years) (22) it was reported that consumption of vegetables has been associated with higher FEV 1 . In Cycle 3, medium consumption of vegetables was associated with higher FVC and higher $\mathrm{FEV}_{1}$. These results support the previous research to some degree. It is interesting that medium consumption of vegetables could be beneficial for lung function, but not high consumption. The current study did 
not look at the dark green vegetables specifically which is beneficial for lung health $(95,96)$. Inclusion of total vegetables might be the possible reason for this medium consumption being significant.

\section{$\underline{\text { Milk }}$}

A study in 2013 in the US among adults (45-84 years) reported that total dairy consumption has been associated with higher FVC and high-fat dairy has been associated with lower $\mathrm{FEV}_{1} / \mathrm{FVC}$ (134). In Cycle 3, this study similarly provided evidence that medium consumption of milk is associated with higher $\mathrm{FEV}_{1}$, higher $\mathrm{FEV}_{1} / \mathrm{FVC}$ ratio, and higher $\mathrm{FEF}_{25-75 \%}$ complementing the previous work. Milk is considered as an anti-Mediterranean Diet (93) so a high consumption of milk may not be beneficial for health. However, Canada is a cold country and in winter sun is often covered with cloud. For this reason, milk consumption is necessary for obtaining Vitamin D and other nutritional content. Thus, this medium consumption of milk may be beneficial for lung health.

\section{Dietary fat}

A higher proportion of dietary fat has been associated with lower $\mathrm{FVC}$ and $\mathrm{FEV}_{1}$ as reported in a study in 2010 in Australia by using adult participants (55-85 years) (145). In Cycles 1 and 2 of the current study, high consumption of dietary fat was associated with higher FVC which does not support the findings of the previous study. The possible reason for this discrepancy might be due to the inclusion of only regular fat salad dressing and regular fat potato chips together in the dietary fat variable in this study. This current study did not include the other varieties of fat due to lack of available data specifically on fat consumption. We should be cautious in the 
conclusion that high intake of fat was associated with higher lung function based on this limited information.

\section{$\underline{\text { Eggs }}$}

There has not been a previous study examining the effects of eggs on lung function. However, a 2009 study from Auckland stated that consumption of eggs has been associated with decreased risk of wheeze in children (6-7 years) (146). In our study, eggs consumption provided controversial results where egg intake was associated with higher $\mathrm{FEV}_{1}$ in Cycle 1, while egg intake was associated with lower $\mathrm{FEV}_{1}$ in Cycle 3. Part of this inconsistency could be due to the fact that eggs consumption had specific information such as "egg enriched with $\omega-3$ fatty acid" in Cycle 3 instead of only "eating eggs or eggs dishes" which was used in the other Cycles.

\section{Beans and nuts}

There has not been a previous study which reported the effect of bean consumption specifically on lung function. A study conducted in 2013 in India among the adult Indians (20-49 years) (Third National Family Health Survey (NFHS)) (147) and in another study conducted in 2010 in the UK among adults (16-50 years) investigated bean consumption as a part of dietary patterns associated with asthma (148). Both studies found that less or no intake of beans was associated with the development of asthma (147) (148). In Cycle 3, a high consumption of beans was associated with higher $\mathrm{FVC}$ and higher $\mathrm{FEV}_{1}$ which supports the evidence despite the differences in outcome.

\section{Potatoes}

No previous research investigating potato consumption and lung function among adults has been completed. A study in 2003 in the Netherlands among children (1-3 years) reported that 
diets rich with potatoes were associated with lower lung function (149). In Cycle 3, medium and high consumption of potatoes were associated with lower FVC and lower FEV 1 . These results support the past evidence.

\section{$\underline{\text { Soft drinks }}$}

There has not been a study reporting the impact of soft drinks on lung function. However, a study conducted in 2012 in Australia among adults ( $\geq 16$ years) showed that increased consumption of soft drinks was associated with asthma/COPD (14). In Cycle 2, high consumption of soft drinks was associated with lower FVC and lower $\mathrm{FEV}_{1}$ which supports the previous study though their outcome was asthma/COPD.

\subsubsection{Canada Food Guide}

There has not been a previous Canadian study that has explored the association between following the Canada Food Guide and lung function. The Canada Food Guide is a guideline for consuming food for the Canadian people. Dietary consumption based on the Canada Food Guide was categorized as "meeting" and "not-meeting" daily requirement except for grains in Cycle 3 due to the absence of the minimum required observations. Overall most participants were not meeting the requirements set out by the Canada Food Guide. The Canada Food Guide has suggested eating more vegetables and fruits, whole grains, drinking skimmed milk (1\% or $2 \%)$, and consuming a small amount of fat each day (89). Analysis of the associations between dietary recommendations based on the Canada Food Guide and lung function allowed me to investigate overall relationships between diet and lung function not focussed on individual components of the diet. Although, I found inconsistencies in the results throughout Cycles, "not meeting" the requirements of meats were associated with lower $\mathrm{FEV}_{1}$ and lower $\mathrm{FEV}_{1} / \mathrm{FVC}$ in Cycle 1 . And in Cycle 3, "not meeting" the requirements of vegetables and fruits were associated with lower FEV . $_{\text {. }}$ 
These results indicate that meeting the Canada Food Guide requirements may be beneficial for lung health.

\subsubsection{Mediterranean Diet}

Mediterranean like diet patterns have been shown to be protective for lung function (78). A study in 2016 in Spain showed that Mediterranean like diet pattern was associated with preserved lung function among adults (35-70 years) (78). In our study, we found inconsistent results by Cycles and results that were in the opposite direction that we expected between the Mediterranean Diet Score and lung function in Cycle 3 where the modified Mediterranean Diet Score was associated with lower FVC and lower $\mathrm{FEV}_{1}$. In our study, we had a lack of information about olive oil, fast food, saturated and unsaturated fat intake in developing the Mediterranean Diet Score. This may have led to finding opposite results than the previous studies.

\subsubsection{Biomarkers}

\section{Chloride}

There are a limited number of studies looking at biomarkers on lung function. A previous study published in 2008 among non-institutionalized US adults (17 years and older) showed that normal levels of calcium, chloride, $\beta$-cryptoxanthin, lutein/zeaxanthin, lycopene, selenium, and iron were associated with higher $\mathrm{FEV}_{1}$ (150). We found consistent results where blood chloride

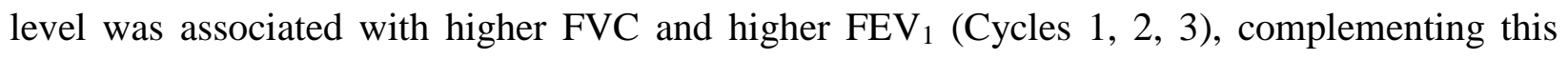
previous research.

\section{$\underline{\text { C-reactive protein }(\mathrm{CRP})}$}

A study published in 2008 in Denmark among adults (20-29 years) reported that a high level of CRP has been associated with lower lung function (151). CRP is a systemic inflammation marker. A higher systemic inflammation level has been associated with lower lung function (104). 
Our study found similar results consistently in Cycles 1 and 3 where CRP was associated with lower $\mathrm{FVC}, \mathrm{FEV}_{1}$, and $\mathrm{FEF}_{25-75 \%}$ supporting the previous work showing that inflammation can negatively affect lung function.

\section{$\underline{\text { Vitamin D }}$}

A study published in 2011 in Britain among adults (at age 45 years) (152) and another study in 2011 in the US among non-institutionalized civilians (12-59 years) (153) showed that serum Vitamin D has been associated with higher lung function. Vitamin D protects the airway by reducing the susceptibility and severity of the respiratory infections (98). Consistent results were

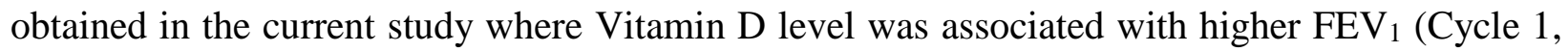
3).

\section{$\underline{\text { Serum folate }}$}

A study published in 2010 in Denmark among adults (30-60 years) has shown significant associations between higher serum folate and decreased risk of reduced lung function (reduced lung function: $\mathrm{FEV}_{1}<80 \%$ ), while low dietary consumption of folate has been significantly associated with reduced lung function (107). In addition, higher levels of serum folate have been associated with self-reported doctor diagnosed asthma and lowered airway symptoms (107). Folate deficiency may be associated with altering the cell mediated immunity leading to increased susceptibility to infection and decreased resistance to infection (154). Consistent with these previous studies, results were observed in our study where red blood cell folate is associated with higher $\mathrm{FEV}_{1}$ in Cycle 3. However, the results were inconsistent in Cycle 2 where red blood cell folate was associated with lower a $\mathrm{FEV}_{1} / \mathrm{FVC}$ ratio. 


\section{$\underline{\text { Vitamin B12 }}$}

Serum levels of Vitamin B12 were not associated with lung function in a previous study conducted in 2010 in Denmark among the adults (30-60 years) (107). Vitamin B12 interacts with folate metabolism and deficiencies may increase a person's susceptibility to infection (154). In the current study, Vitamin B12 was associated inconsistently with lower FEV 1 (Cycles 1, 3), lower $\mathrm{FEF}_{25-75 \%}$ (Cycle 1), and the higher $\mathrm{FEV}_{1} / \mathrm{FVC}$ ratio of the current study (Cycle 2). These results were also inconsistent with the previous study suggesting that the relationship between Vitamin B12 and lung function may be complex.

\section{$\underline{\text { Calcium }}$}

Again, in another study in 2011 in the US among non-institutionalized civilians (12-59 years) calcium level has not been associated with lung function (153) while normal levels of Calcium were associated with higher $\mathrm{FEV}_{1}$ as discussed previously (150). Calcium plays a key role in calcium dependent excitation-contraction linked together in airway smooth muscle (155). Lack of intracellular calcium may cause inappropriate contraction of smooth muscle (inappropriate contraction associated with higher resistance which is one of the symptoms of acute asthma) (155). Our study calcium level was associated with higher $\mathrm{FEV}_{1}$ (Cycle 2), higher $\mathrm{FEV}_{1} / \mathrm{FVC}$ ratio (Cycle 3), and higher $\mathrm{FEF}_{25-75 \%}$ (Cycle 2).

\section{Potassium and Sodium}

A study in 2008 among non-institutionalized US adults (17 years and older) showed that potassium and sodium has been associated with lower $\mathrm{FEV}_{1}(150)$. Sodium is an important marker in regulating smooth muscle tone (20). A higher influx of sodium and potassium within the smooth muscle of the airway may cause hyperpolarization which leads to airway diseases, specifically 
airway hyper-reactivity (156) (157). Our study found similar results where potassium levels were associated with lower $\mathrm{FVC}$ and $\mathrm{FEV}_{1}$, while sodium level was associated with lower $\mathrm{FEF}_{25-75 \% \text {, }}$ both in Cycle 2. Though these results have not been consistent throughout the Cycles it supports the previous study.

\subsection{Internal and external validity of the findings}

\subsubsection{Internal validity}

The CHMS developed quality assurance and quality control protocols in every aspect of fieldwork to maximize the reliability and validity of the data and to reduce systemic bias (125). Quality assurance included supervision of household interviewing by an interviewer manager for ensuring quality control. Quality assurance for the Mobile Examination Center included staff selection and training, instructions to respondents (pre-testing guidelines), and issues related to data collection. All staff had appropriate education and training for their respective positions. To ensure consistent measurement techniques, procedure manuals and training guides were developed by expert review and consultation (125).

\subsubsection{Selection bias}

Selection bias has been considered in the CHMS (125). The CHMS had an excellent participation rates for all Cycles (Cycle 1: 85\%, Cycle 2: 81.7\%, Cycle 3: 79\%) (124-126).

It is possible that less healthy people were less likely to go to the Mobile Examination Centers (124-126). Likewise, bias may be caused by the oversampling of those aged 20-39 who were living with children (6-11 years old). The survey weights and bootstrap weights were created using post-stratification by age group and sex, with an additional adjustment for individuals who were 20-39 years old living with and without children (aged 3-11 years) to account for any potential bias due to oversampling (124-126). 


\subsubsection{Non-response bias}

The CHMS experienced several levels of potential non-response (124-126). First, the selected house may deny providing the household composition. Second, the selected participants among the household members may refuse to answer the questionnaire. Third, the individual may reject participating in the Mobile Examination Center visit. Finally, the individual may decline to provide blood and/or urine for the laboratory tests for analysis (125). At each level of non-response (available for respondents and non-respondents), Statistics Canada used a logistic regression model to identify variables which explained the most non-response. The non-response modifications were applied within these groups to adjust the survey weights. Using the survey weights to create estimates should minimize non-response bias due to differences in the survey variables between respondents and non-respondents (124-126).

\subsubsection{Information bias}

Information bias should be considered in this study. Information bias may arise from the measurement methods or credibility of the exposure (dietary information) and/or outcomes (lung function). Information was collected by direct interviewing, which could be subject to errors in recall or problems in reporting sensitive information.

Regarding the exposure measures, all dietary frequency information that was used in this study was collected by asking about the frequency of consuming that dietary factor per year. People may have the tendency to over-state that they were eating a healthy diet. Also, people may have difficulty in recall the number of servings of the food. In an attempt to overcome this, CHMS data was collected using validated standardized questionnaires and objective biomarkers.

The outcome considered (lung function) was a strength as it was objectively measured using standardized methods and an external reviewer reviewed the lung function results. The role 
of the external reviewer was to identify unacceptable efforts based on the testing criteria of the American Thoracic Society in order to assist both the participants and the data analyst. All acceptable trials were reviewed to determine whether the test results for FVC and $\mathrm{FEV}_{1}$ represented a maximal effort by the respondent (quality) and met the reproducibility criteria of 150 ml. Only acceptable efforts were included.

\subsubsection{Confounding}

In our study, we attempted to adjust for a number of potential confounders by using multivariate analyses. The thesis was focused on respiratory health and the common and important known risk factors and confounders were considered. To enhance this, we fitted the model based on confounding in the data as well as confounding in the literature.

\subsubsection{Cross-sectional design and causality}

We must consider causality based on Hill's criteria (158). The most important of Hill's criteria include: temporality, strength, consistency, plausibility, and dose response. As the nature of this study was a cross-sectional design, temporality is difficult to establish and is a limitation. The $\beta$-coefficients tended to be weak (only bean, meat, grains, dietary fat, eggs, milk, fruits, soft drinks, and potato have a $\beta$-coefficient of $0.10-0.17)$ and these $\beta$-coefficients were inconsistent throughout the Cycles and food groups. This study demonstrated statistically significant associations between some of the dietary factors and lung function though it was not consistent throughout the Cycles. Some findings were consistent (e.g. vegetables, fruits, potatoes) when compared to previous literature while some findings were not (e.g. meats, fish, dietary fat) based on the previous study. There were some differences in the questionnaire (e.g. meats, fish) specifically in Cycle 3. The dietary fat food group did not include all types of fat (e.g. oil consumption). These are the reasons that might explain the inconsistency of some results. A dose 
response relationship was seen for some of the dietary variables (e.g. bean, dietary fat, soft drinks, eggs, fruits, and meats). However, it was also common to see associations only with the middle tertile suggesting that the associations may not only be linear.

\subsubsection{External Validity}

Our findings can be generalized to the Canadian adult population as Statistics Canada developed the study to be representative of the Canadian population. Despite this, not all provinces were included in data collection (e.g. Saskatchewan). Also, while Statistics Canada sampled and weighted the data to be representative of the total Canadian adult population, the actual sample size of data collected was much smaller (approximately 3,600 adults), which may lead to criticisms about the true representativeness. Many provinces have regional differences in culture, population, religion, and governance. Variations in these factors could modify their dietary choices. Another limitation may be the applicability of these findings to non-Caucasian adults' due to a large proportion of the respondents being Caucasian adults $(82.3 \%, 77.6 \%$, and $75.1 \%$ for Cycle 1,2 , and 3 respectively). Furthermore, due to eating habits varying from country to country, or even within different regions within countries, the global generalization of the findings should also be carefully considered.

\subsection{Other Strengths and Limitations}

The other strengths of this study include it was a large population based study with a representative sample using standardized questionnaires, standard measures of spirometry, and objective biomarkers which can reduce the potential for measurement error. Using objective biomarkers was the major strength of this study since it could capture the normal or diseased processes in the body (106) with a reduction in the potential for bias, which allows for stronger, more valid results. 
The analysis was adjusted for socioeconomic status (SES) (i.e. income and education) which is a strength for this study. SES is an important measure for the dietary assessment as it could modify the dietary selections, availability, and affordability of healthy food. Low SES may lead to cheap and unhealthy food selection which is responsible for many nutrition related diseases (159). In this study, there were many different dietary measures considered including several that had never been researched independently in relation to lung function previously such as beans and nuts consumption. Although the data was improved by collecting more detailed information in Cycle 3, this led to variability within the questionnaires between Cycles for exposure measurement, which, may have caused potential bias in the observed results and inconsistency between Cycles.

Some food groups may not fully represent the information being sought. For instance, within the meats category, only red meat information was available but no information about chicken. Dietary fat had a very limited assessment. It included only salad dressing, potato chips (Cycles 1 and 2), and margarine (Cycle 3) which does not provide information on total dietary fat consumption. All foods within a grouping were combined to create a single variable which may lead to some issues in assessing the associations. For example, French fried potatoes can be considered as fast food and might not be good as baked or mashed potatoes. If French fried potatoes have a harmful effect and mashed potatoes have a beneficial effect, then it is possible to get a neutral result. Inclusion of different subcategories of food (e.g. French fried and mashed potatoes grouped together, or different types of vegetables grouped together) may lead to misclassification within food groups. The information collected for the food groups also differ by cycles and methods causing inconclusive results. 
The original Canada Food Guide suggested daily serving sizes (89) as the dietary recommendation. Unfortunately, we did not have serving size information. In the CHMS, only "number of times" for each food type was available. Again, the adult dietary recommendation started from 19 years for the Canada Food Guide, whereas our study included those 18 years of age as the beginning of adult age group. However, absence of serving sizes and a 1-year age overlap may affect the results and was a limitation for this study. Specifically, without considering the size of servings, there is potential for misclassification in consumption assessment. The results of the Mediterranean Diet were somewhat unexpected. The score was constructed as a modified Mediterranean Diet Score due to the absence of some important dietary components (e.g. olive oil, fast food, saturated and unsaturated lipids, ethanol) in the CHMS. This may have led to differences in associations compared to other studies $(78,90)$.

In the past, researchers have included $\beta$-carotene (Vitamin A), Vitamin E, and Vitamin C as both dietary assessment and biomarkers (86) or assessed through the food frequency questionnaires only $(82,85)$. However, in this study, we could not include these due to a lack of available information. Although, Vitamin $\mathrm{C}$ was available only in Cycle 3, it was excluded from the analysis for consistency between Cycles.

This study was an exploratory study with many analyses completed. A potential concern is alpha inflation error due to multiple comparisons. To overcome this, a Bonferroni test could be performed to help control for potentially false positive results (type I error) (160). Nevertheless, the multiple comparisons were not performed because in a practical situation, Bonferroni corrections could be extremely conservative and lead to a high rate of false negatives (type II error) (160) and given the exploratory nature of the study, it was decided to avoid this process. 


\subsection{Recommendations and Applications}

Based on the findings in this thesis, several hypotheses can be generated regarding the relationship between diet and lung function. In our study, we found that eating healthy diets (e.g. higher fruits, lower soft drinks intake) leads to higher lung function among adults. Even though this association has not been proven to be causal, the findings of protective effects of diets (grains, fruits, and vegetables) were consistent in many countries. Identifying the possible protective effects on lung function suggests possible future prevention consideration.

\subsection{Future Research Directions}

There are several suggestions/recommendations for future research that can be provided. 1) In order to unravel the direction of exposures leading to diseases, there is a need for more sophisticated and appropriate research designs used such as longitudinal studies (e.g. birth cohorts) looking at the timing of dietary exposures in relation to lung function and respiratory disease development. 2) It would also be worthwhile to perform similar studies in other rural and urban communities, and with more ethnically diverse study populations in order to further assess the generalizability of the current study findings. 3) It is recommended that more comprehensive exposure measurement methods be used such as objective measures of antioxidant levels (Vitamin A, E, and C) to identify which factors are responsible for the associations with lung function and respiratory diseases. 4) Population-based studies including children, adolescents, and adults are required to assess the etiologic fraction, which is an important measure for the lung diseases attributable to exposures of interests (e.g. nutritional exposures). 5) Considering lower limit of normal (LLN) while analyzing the lung function measurements (161). 6) Assessment of dietary status using other dietary markers such as the Healthy Eating Index (HEI) in relation to lung function is recommended for further studies (81). The HEI, 2010 is an improved diet quality index 
for Canadians measured by calculating the nutrients from the dietary intake and it could be helpful for making dietary recommendation for chronic diseases including lung function $(81,162)$ because it will directly assess nutrients as opposed to food types. 7) Dietary factors could be classified by specifying the function of the food group (e.g. anti-inflammatory food) as well as by measuring inflammatory makers from blood could be conducted to observe the anti-inflammatory effect of diets on lung function. 8) Studies reported that fast foods are associated with increased risk of asthma $(116,163)$. Therefore, investigation of fast food and fats could be done to observe the impact on lung function as a practical public health importance. 9) Assessment of Canada Food Guide by adding dietary consumption by daily serving sizes. 10) A community-based intervention program can be implemented by focusing on participants experienced improvements in dietary quality, lung function, and indicators of chronic lung diseases. 11) By training and educating the health-care professionals on the relationship between diet and lung function for preventing diseases and promoting lung health.

\subsection{Conclusion}

This thesis examined the association between dietary factors and lung function along with an exploration of the relationship with lung function using objectively measured biomarkers among a large, representative population of adults in Canada. Lung function is effort dependent and reflects only current lung function. There were a lot of inconsistencies, but the study does provide good information for potential hypotheses. Findings suggest that dietary exposures and lung function have an association; however, there were some inconsistencies throughout the Cycles, mostly with the report of dietary intake. Further studies (e.g. cohort designs or similar to this study) and innovative methods (e.g. a collection of dietary information more accurately, dividing diet by nutrients, use of nutritional marker especially designed for dietary assessment) 
designed specially to investigate the effects of independent associations of nutrients and dietary factors on lung function. 


\section{References}

1. World Health Organization. Global surveillance, prevention and control of Chronic respiratory diseases: A comprehensive approach. 2007;155.

2. Huang S, Lin K, Pan W. Dietary factors associated with physician-diagnosed asthma and allergic rhinitis in teenagers: analyses of the first Nutrition and Health Survey in Taiwan. Clin Exp Allergy. 2001;31(2):259-64.

3. Ellwood P, Asher MI, Björkstén B, Burr M, Pearce N, Robertson CF. Diet and asthma, allergic rhinoconjunctivitis and atopic eczema symptom prevalence: an ecological analysis of the International Study of Asthma and Allergies in Childhood (ISAAC) data. Eur Respir J. 2001;17(3):436-43.

4. Beasley R, Crane J, Lai C, Pearce N. Prevalence and etiology of asthma. Allergy Clin Immunol. 2000;105(2):S466-72.

5. Cruz A, Bousquet J, Khaltaev N. Global surveillance, prevention and control of chronic respiratory diseases: a comprehensive approach. World Health Organization. 2007.

6. Cooper P, Rodrigues L, Cruz A, Barreto M. Asthma in Latin America: a public heath challenge and research opportunity. Allergy. 2009;64(1):5-17.

7. Yoo KH, Kim YS, Sheen SS, Park JH, Hwang YI, Kim S-H, et al. Prevalence of chronic obstructive pulmonary disease in Korea: the fourth Korean National Health and Nutrition Examination Survey, 2008. Respirology. 2011;16(4):659-65.

8. Barreiro TJ, Perillo I. An approach to interpreting spirometry. Am Fam Physician. 2004;69(5):1107-14. 
9. Yawn BP, Enright PL, Lemanske RF, Israel E, Pace W, Wollan P, et al. Spirometry can be done in family physicians' offices and alters clinical decisions in management of asthma and COPD. CHEST J. 2007;132(4):1162.

10. Pellegrino R, Viegi G, Brusasco V, Crapo RO, Burgos F, Casaburi R, et al. Interpretative strategies for lung function tests. Eur Respir J. 2005;26(5):948-68.

11. Paeratakul S, White MA, Williamson DA, Ryan DH, Bray GA. Sex, race/ethnicity, socioeconomic status, and BMI in relation to self-Perception of overweight. Obes Res. 2002;10(5):345-50.

12. Darmon N, Drewnowski A. Does social class predict diet quality? Am J Clin Nutr. 2008;87(5):1107-17.

13. Kim J-H, Ellwood PE, Asher MI. Diet and asthma: looking back, moving forward. Respir Res. 2009;10(1):49.

14. Shi Z, Dal Grande E, Taylor AW, Gill TK, Adams R, Wittert GA. Association between soft drink consumption and asthma and chronic obstructive pulmonary disease among adults in Australia. Respirology. 2012;17(2):363-9.

15. Protudjer JLP, Sevenhuysen GP, Ramsey CD, Kozyrskyj AL, Becker AB. Low vegetable intake is associated with allergic asthma and moderate-to-severe airway hyperresponsiveness. Pediatr Pulmonol. 2012;47(12):1159-69.

16. Castro-Rodriguez JA, Garcia-Marcos L. What are the effects of a Mediterranean Diet on allergies and asthma in children? Front Pediatr. 2017;5.

17. Jiang R, Camargo C, Varraso R, Paik D. Consumption of cured meats and prospective risk 
of chronic obstructive pulmonary disease in women. Am J Clin Nutr. 2008;87:1002-8.

18. Hooper R, Heinrich J, Omenaas E, Sausenthaler S, Garcia-Larsen V, Bakolis I, et al. Dietary patterns and risk of asthma: results from three countries in European Community Respiratory Health Survey-II. Br J Nutr. 2010;103(9):1354-65.

19. Nagel G, Weinmayr G, Kleiner A, Garcia-Marcos L, Strachan DP. Effect of diet on asthma and allergic sensitisation in the International Study on Allergies and Asthma in Childhood (ISAAC) Phase Two. Thorax. 2010;65(6):516-22.

20. Romieu I, Trenga C. Diet and obstructive lung diseases. Epideologic Rev. 2001;23(2):268-87.

21. Baker J., Ayres J. Diet and asthma. Respir Med. 2000;94(10):925-34.

22. Tabak C, Smit H, Heederik D, Ocke M, Kromhout D. Diet and chronic obstructive pulmonary disease: independent beneficial effects of fruits, whole grains, and alcohol (the MORGEN study). Clin Exp Allergy. 2001;31:747-55.

23. Tabak C, Feskens EJM, Heederik D, Kromhout D, Menotti A. Fruit and fish consumption: a possible explanation for population differences in COPD mortality (The Seven Countries Study). Eur J Clin Nutr. 1998;52(11):819-25.

24. Wood LG, Gibson PG, Garg ML. Biomarkers of lipid peroxidation, airway inflammation and asthma. Eur Respir J. 2003;21(1):177-86.

25. Britton JR, Pavord ID, Richards K a, Knox a J, Wisniewski a F, Lewis S a, et al. Dietary antioxidant vitamin intake and lung function in the general population. Am J Respir Crit Care Med. 1995;151(5):1383-7. 
26. Tujague J, Bastaki M, Holland N, Balmes JR, Tager IB. Antioxidant intake, GSTM1 polymorphism and pulmonary function in healthy young adults. Eur Respir J. $2006 ; 27(2): 282-8$.

27. Hanson C, Lyden E, Rennard S, Mannino DM, Rutten EPA, Hopkins R, et al. The relationship between dietary fiber intake and lung function in the National Health and Nutrition Examination Surveys. Ann Am Thorac Soc. 2016;13(5):643-50.

28. Miller MR, Hankinson J, Brusasco V, Burgos F, Casaburi R, Coates a., et al. Standardisation of spirometry. Eur Respir J. 2005;26(2):319-38.

29. Mottram C. Ruppel's Manual of Pulmonary Function Testing 10: Ruppel's Manual of Pulmonary Function Testing. Elsevier Health Sciences. 2013. p. 528.

30. Swanney MP, Ruppel G, Enright PL, Pedersen OF, Crapo RO, Miller MR, et al. Using the lower limit of normal for the FEV1/FVC ratio reduces the misclassification of airway obstruction. Thorax. 2008;63(12):1046-51.

31. Clinical guideline [CG101]. Chronic obstructive pulmonary disease in over 16s: diagnosis and management, NICE. 2010.

32. Diane Lougheed M, Lemiere C, Ducharme FM, Licskai C, Dell SD, Rowe BH, et al. Canadian Thoracic Society 2012 guideline update: diagnosis and management of asthma in preschoolers, children and adults: executive summary. Can Respir J. 2012;19(6).

33. Mannino DM. Lung function and mortality in the United States: data from the First National Health and Nutrition Examination Survey follow up study. Thorax. 2003;58(5):388-93. 
34. Miller A, Becklake MR, Crapo RO, Buist S, Burrows B, Clausen JL, et al. Lung function testing: selection of reference values and interpretative strategies. Am Rev Respir Dis. 1992;146(5_pt_1):1368-9.

35. Ranu H, Wilde M, Madden B. Pulmonary function tests. Ulster Med J. 2011;80(2):84-90.

36. Bahadori K, Doyle-Waters M, Marra C, Lynd L, Alasaly K, Swiston J, et al. Economic burden of asthma: a systematic review. BMC Pulm Med. 2009;9(1):24.

37. Global Initiative for Chronic Obstructive Lung Disease (GOLD). Global strategy for the diagnosis, management, and prevention of chronic obstructive pulmonary disease. 2016.

38. Ehteshami-Afshar S, FitzGerald JM, Doyle-Waters MM, Sadatsafavi M. The global economic burden of asthma and chronic obstructive pulmonary disease. Int J Tuberc Lung Dis. $2016 ; 20(1): 11-23$.

39. Global Initative for Asthma. Global strategy for asthma management and prevention (update 2015). 2015.

40. Pearce N, Aït-Khaled N, Beasley R, Mallol J. Worldwide trends in the prevalence of asthma symptoms: phase III of the International Study of Asthma and Allergies in Childhood (ISAAC). Thorax. 2007;62(9):758-66.

41. Auckland, New Zealand: Global Asthma Network 2014. The Global Asthma Report 2014. 2014.

42. Public Health Agency of Canada. Fast facts about asthma. 2011.

43. Bedouch P, Sadatsafavi M, Marra CA, FitzGerald JM, Lynd LD. Correction: Trends in asthma-related direct medical costs from 2002 to 2007 in British Columbia, Canada: A 
population based-cohort study. PLoS One. 2013;8(6).

44. Lent N, Skolink N. GOLD guidelines for the management of COPD - 2017 update. 2017.

45. Lopez AD, Shibuya K, Rao C, Mathers CD, Hansell AL, Held LS, et al. Chronic obstructive pulmonary disease: current burden and future projections. Eur Respir J. 2006;27(2):397-412.

46. Buist AS, McBurnie MA, Vollmer WM, Gillespie S, Burney P, Mannino DM, et al. International variation in the prevalence of COPD (the BOLD Study): a population-based prevalence study. Lancet. 2007;370(9589):741-50.

47. Khakban A, Sin DD, FitzGerald JM, Ng R, Zafarí Z, McManus B, et al. Ten-year trends in direct costs of COPD. Chest. 2015;148(3):640-6.

48. Gerald LB, Grad R, Turner-Henson A, Hains C, Tang S, Feinstein R, et al. Validation of a multistage asthma case-detection procedure for elementary school children. Pediatrics. 2004;114(4):e459-68.

49. Schoenberg JB, Beck GJ, Bouhuys A. Growth and decay of pulmonary function in healthy blacks and whites. Respir Physiol. 1978;33(3):367-93.

50. Griffith KA, Sherrill DL, Siegel EM, Manolio TA, Bonekat HW, Enright PL. Predictors of loss of lung function in the elderly. Am J Respir Crit Care Med. 2001;163(1):61-8.

51. Knudson RJ, Lebowitz MD, Holberg CJ, Burrows B. Changes in the normal maximal expiratory flow-volume curve with growth and aging. Am Rev Respir Dis. $1983 ; 127(6): 725-34$.

52. Wang X, Dockery DW, Wypij D, Fay ME, Ferris BG. Pulmonary function between 6 and 
18 years of age. Pediatr Pulmonol. 1993;15(2):75-88.

53. Gold DR, Acevedo-Garcia D. Immigration to the United States and acculturation as risk factors for asthma and allergy. J Allergy Clin Immunol . 2005;116:38-41.

54. Gaffney AW, Hang J, Lee M-S, Su L, Zhang F, Christiani DC. Socioeconomic status is associated with reduced lung function in China: an analysis from a large cross-sectional study in Shanghai. BMC Public Health. 2015;16(1):96.

55. Bacon SL, Bouchard A, Loucks EB, Lavoie KL. Individual-level socioeconomic status is associated with worse asthma morbidity in patients with asthma. Respir Res. 2009;10:125.

56. Tager IB, Hanrahan JP, Tosteson TD, Castile RG, Brown RW, Weiss ST, et al. Lung function, pre and post-natal smoke exposure, and wheezing in the first year of life. Am Rev Respir Dis. 1993;147(4):811-7.

57. Johnston IDA, Strachan DP, Anderson HR. Effect of pneumonia and whooping cough in childhood on adult lung function. N Engl J Med. 1998;338(9):581-7.

58. Anthonisen NR, Connett JE, Murray RP. Smoking and lung function of lung health study participants after 11 years. Am J Respir Crit Care Med. 2002;166(5):675-9.

59. Chaudhuri R, Livingston E, Mcmahon AD, Lafferty J. Effects of smoking cessation on lung function and airway inflammation in smokers with asthma. Am J Respir Crit Care Med. 2006;174(2).

60. Taylor DR, Fergusson DM, Milne BJ, Horwood LJ, Moffitt TE, Sears MR, et al. A longitudinal study of the effects of tobacco and cannabis exposure on lung function in young adults. Addiction. 2002;97(8):1055-61. 
61. Kanner RE Connett JE, Lung Health Study Research Group ANR. Lower respiratory illnesses promote FEV(1) decline in current smokers but not ex-smokers with mild chronic obstructive pulmonary disease: results from the lung health study. Am J Respir Crit Care Med. 2001;164(3):358.

62. Gold DR, Wang X, Wypij D, Speizer FE, Ware JH, Dockery DW. Effects of cigarette smoking on lung function in adolescent boys and girls. N Engl J Med. 1996;335(13):9317.

63. Tracey M, Villar A, Dow L, Coggon D, Lampe FC, Holgate ST. The influence of increased bronchial responsiveness, atopy, and serum IgE on decline in FEV1. A longitudinal study in the elderly. Am J Respir Crit Care Med. 1995;151(3):656-62.

64. Grol MH, Gerritsen J, Vonk JM, Schouten JP, Koeter GH, Rijcken B, et al. Risk factors for growth and decline of lung function in asthmatic individuals up to age 42 years. Am $\mathrm{J}$ Respir Crit Care Med. 1999;160(6):1830-7.

65. Çolak Y, Marott JL, Vestbo J, Lange P. Overweight and obesity may lead to underdiagnosis of airflow limitation: findings from the Copenhagen City Heart Study. J Chronic Obstr Pulm Dis. 2015;12(1):5-13.

66. O’Donnell DE, Ciavaglia CE, Neder JA. When obesity and chronic obstructive pulmonary disease collide. Physiological and clinical consequences. Ann Am Thorac Soc. 2014;11(4):635-44.

67. Kimura N. Changing patterns of coronary heart disease, stroke, and nutrient intake in Japan. Prev Med (Baltim). 1983 Jan;12(1):222-7. 
68. Brigham EP, Kolahdooz F, Hansel N, Breysse PN, Davis M, Sharma S, et al. Association between western diet pattern and adult asthma: a focused review. Ann Allergy, Asthma Immunol. 2015;114(4):273-80.

69. Celik F, Topcu F. Nutritional risk factors for the development of chronic obstructive pulmonary disease (COPD) in male smokers. Clin Nutr. 2006;25(6):955-61.

70. Hanson C, Rutten EPA, Wouters EFM, Rennard S. Diet and vitamin D as risk factors for lung impairment and COPD. Transl Res. 2013;162(4):219-36.

71. Keranis E, Makris D, Rodopoulou P, Martinou H, Papamakarios G, Daniil Z, et al. Impact of dietary shift to higher-antioxidant foods in COPD: a randomised trial. Eur Respir J. 2010;36(4):774-80.

72. Shaheen SO, Jameson KA, Syddall HE, Aihie Sayer A, Dennison EM, Cooper C, et al. The relationship of dietary patterns with adult lung function and COPD. Eur Respir J. 2010;36(2):277-84.

73. Varraso R, Fung TT, Barr RG, Hu FB, Willett W, Camargo, Carlos A J. Prospective study of dietary patterns and chronic obstructive pulmonary disease among US women. Am J Clin Nutr. 2007;86(2):488-95.

74. Watson L, Margetts B, Howarth P, Dorward M, Thompson R, Little P. The association between diet and chronic obstructive pulmonary disease in subjects selected from general practice. Eur Respir J. 2002;20(2):313-8.

75. Devereux G, Seaton A. Diet as a risk factor for atopy and asthma. J Allergy Clin Immunol. 2005;115:1109-18. 
76. Fogarty A, Lewis SA, Scrivener SL, Antoniak M, Pacey S, Pringle M, et al. Oral magnesium and vitamin $\mathrm{C}$ supplements in asthma: a parallel group randomized placebocontrolled trial. Clin Exp Allergy. 2003;33(10):1355-9.

77. Pearson PJK, Lewis SA, Britton J, Forgarty A. Vitamin E supplements in asthma: a parallel group randomised placebo controlled trial. Thorax. 2004;59(8):652-6.

78. Sorli-Aguilar M, Martin-Lujan F, Flores-Mateo G, Arija-Val V, Basora-Gallisa J, SolaAlberich R. Dietary patterns are associated with lung function among Spanish smokers without respiratory disease. BMC Pulm Med. 2016;16(1):162.

79. Niruban SJ, Alagiakrishnan K, Beach J, Senthilselvan A. Association between vitamin D and respiratory outcomes in Canadian adolescents and adults. J Asthma. 2015;52(7):65361.

80. Wroblewska I, Olesniewicz P, Kurpas D, Soltysik M, Blaszczuk J. Analysis of spirometry results in hospitalized patients aged over 65 years. Dove Press J. 2015;3:1071-6.

81. Root MM, Houser SM, Anderson JJB, Dawson HR. Healthy Eating Index 2005 and selected macronutrients are correlated with improved lung function in humans. Nutr Res. 2014;34(4):277-84.

82. Bentley AR, Kritchevsky SB, Harris TB, Holvoet P, Jensen RL, Newman AB, et al. Dietary antioxidants and forced expiratory volume in $1 \mathrm{~s}$ decline: the health, aging and body composition study. Eur Respir J. 2012;39(4):979-84.

83. Hirayama F, Lee AH, Terasawa K, Kagawa Y. Folate intake associated with lung function, breathlessness and the prevalence of chronic obstructive pulmonary disease. 
Asia Pac J Clin Nutr. 2010;19(1):103-9.

84. Jiang R, Paik DC, Hankinson JL, Barr RG. Cured meat consumption, lung function, and chronic obstructive pulmonary disease among United States adults. Am J Respir Crit Care Med. 2007;175(8):798-804.

85. Butland BK, Fehily AM, Elwood PC. Diet, lung function, and lung function decline in a cohort of 2512 middle aged men. Thorax. 2000;55(2):102-8.

86. Hu G, Cassano PA. Antioxidant nutrients and pulmonary function: the third National Health and Nutrition Examination Survey (NHANES III). Am J Epidemiol. 2000;151(10):975-81.

87. Carey IM, Strachan DP, Cook DG. Effects of changes in fresh fruit consumption on ventilatory function in healthy British adults. Am J Respir Crit Care Med. $1998 ; 158(3): 728-33$.

88. Schwartz J, Weiss ST. The relationship of dietary fish intake to level of pulmonary function in the first National Health and Nutrition Survey (NHANES I). Eur Respir J. 1994;7(10):1821-4.

89. Katamay SW, Esslinger KA, Vigneault M, Johnston JL, Junkins BA, Robbins LG, et al. Eating well with Canada's food guide (2007): development of the food intake pattern. Nutr Rev. 2007;65(4):155-66.

90. Sexton P, Black P, Metcalf P, Wall CR, Ley S, Wu L, et al. Influence of mediterranean diet on asthma symptoms, lung function, and systemic inflammation: a randomized controlled trial. J Asthma. 2013;50(501):75-81. 
91. Trichopoulou A, Costacou T, Bamia C, Trichopoulos D. Adherence to a mediterranean diet and survival in a Greek population. N Engl J Med. 2003;348(26):2599-608.

92. Garcia-Marcos L, Canflanca IM, Garrido JB, Varela AL-S, Garcia-Hernandez G, Grima FG, et al. Relationship of asthma and rhinoconjunctivitis with obesity, exercise and Mediterranean diet in Spanish schoolchildren. Thorax. 2007;62(6):503-8.

93. Psaltopoulou T, Naska A, Orfanos P, Trichopoulos D, Mountokalakis T, Trichopoulou A. Olive oil, the mediterranean diet, and arterial blood pressure: the Greek European prospective investigation into cancer and nutrition (EPIC) study. Am J Clin Nutr. 2004;80(4):1012-8.

94. Kelly FJ. Vitamins and respiratory disease: antioxidant micronutrients in pulmonary health and disease. Proc Nutr Soc. 2005;64(4):510-26.

95. Wood LG, Garg ML, Powell H, Gibson PG. Lycopene-rich treatments modify noneosinophilic airway inflammation in asthma: proof of concept. Free Radic Res. 2008;42(1):94-102.

96. Ochs-Balcom HM, Grant BJB, Muti P, Sempos CT, Freudenheim JL, Browne RW, et al. Antioxidants, oxidative stress, and pulmonary function in individuals diagnosed with asthma or COPD. Eur J Clin Nutr. 2006;60(8):991-9.

97. Holick MF. Vitamin D Deficiency. N Engl J Med. 2007;357(3):266-81.

98. Foong R, Zosky G. Vitamin D deficiency and the lung: disease initiator or disease modifier? Nutrients. 2013;5(8):2880-900.

99. Saadeh D, Salameh P, Baldi I, Raherison C. Diet and allergic diseases among population 
aged 0 to 18 years: myth or reality? Nutrients. 2013;5(9):3399-423.

100. Ichinose M. Differences of inflammatory mechanisms in asthma and COPD. Allergol Int. 2009;58:307-13.

101. Barnes PJ. Similarities and differences in inflammatory mechanisms of asthma and COPD. Breathe. 2011;7(3):229-38.

102. Hancox RJ, Poulton R, Greene JM, Filsell S, Mclachlan CR, Rasmussen F, et al. Systemic inflammation and lung function in young adults. Thorax. 2007;62:1064-8.

103. Fogarty AW, Jones S, Britton JR, Lewis SA, McKeever TM, Fogarty A. Systemic inflammation and decline in lung function in a general population: a prospective study. Thorax. 2007;62:515-20.

104. Yende S, Waterer GW, Newman AB, Bauer DC, Taaffe DR, Jensen R, et al. Inflammatory markers are associated with ventilatory limitation and muscle dysfunction in obstructive lung disease in well functioning elderly subjects. Thorax. 2005;61(1):10-6.

105. Combs GF, Trumbo PR, McKinley MC, Milner J, Studenski S, Kimura T, et al. Biomarkers in nutrition: new frontiers in research and application. Ann N Y Acad Sci. $2013 ; 1278(1): 1-10$.

106. Corella D, Ordovás JM. Biomarkers: background, classification and guidelines for applications in nutritional epidemiology. Nutr Hosp. 2015;31(3):177-88.

107. Thuesen BH, Husemoen LLN, Ovesen L, Jørgensen T, Fenger M, Gilderson G, et al. Atopy, asthma, and lung function in relation to folate and vitamin B12 in adults. Allergy. 2010;65(11):1446-54. 
108. Matsui EC, Matsui W. Higher serum folate levels are associated with a lower risk of atopy and wheeze. J Allergy Clin Immunol. 2009;123(6):1253-9.

109. Black PN, Scragg R. Relationship Between Serum 25-hydroxyvitamin D and pulmonary function in the third National Health and Nutrition Examination Survey. Chest. $2005 ; 128(6): 3792-8$.

110. Pepys MB, Hitschfield GM. C-reactive protein: a critical update. J Clin Investig Nurs Allied Heal Database pg. 2003;111(12):1805-12.

111. Kony S, Zureik M, Driss F, Neukirch C, Leynaert B, Neukirch F. Association of bronchial hyperresponsiveness and lung function with $\mathrm{C}$-reactive protein (CRP): a population based study. Thorax. 2004;59(10):892-6.

112. Chatzi L, Kogevinas M. Prenatal and childhood mediterranean diet and the development of asthma and allergies in children. Public Health Nutr. 2009;12(5):1629-34.

113. Kim JL, Elfman L, Mi Y, Johansson M, Smedje G, Norbäck D. Current asthma and respiratory symptoms among pupils in relation to dietary factors and allergens in the school environment. Indoor Air. 2005;15:170-82.

114. Laerum BN, Wentzel-Larsen T, Gulsvik a., Omenaas E, Gíslason T, Janson C, et al. Relationship of fish and cod oil intake with adult asthma. Clin Exp Allergy. 2007;37:1616-23.

115. Lawson JA, Janssen I, Bruner MW, Hossain A, Pickett W. Asthma incidence and risk factors in a national longitudinal sample of adolescent Canadians: a prospective cohort study. BMC Pulm Med. 2014;14(1):51. 
116. Lee SC, Yang YH, Chuang SY, Liu SC, Yang HC, Pan WH. Risk of asthma associated with energy-dense but nutrient-poor dietary pattern in Taiwanese children. Asia Pac J Clin Nutr. 2012;21(1):73-81.

117. Li J, Xun P, Zamora D, Sood A, Liu K, Daviglus M, et al. Intakes of long-chain omega-3 (n-3) PUFAs and fish in relation to incidence of asthma among American young adults: The CARDIA study. Am J Clin Nutr. 2013;97:173-8.

118. Patel BD, Welch A, Bingham S, Luben R, Day N, Khaw K-T, et al. Dietary antioxidants and asthma in adults. Thorax. 2006;61(5):388-93.

119. Seyedrezazadeh E, Pour Moghaddam M, Ansarin K, Reza Vafa M, Sharma S, Kolahdooz F. Fruit and vegetable intake and risk of wheezing and asthma: A systematic review and meta-analysis. Nutr Rev. 2014;72(7):411-28.

120. Varraso R, Kauffmann F, Leynaert B, Le Moual N, Boutron-Ruault MC, Clavel-Chapelon F, et al. Dietary patterns and asthma in the E3N study. Eur Respir J. 2009;33:33-41.

121. Virtanen SM, Kaila M, Pekkanen J, Kenward MG, Uusitalo U, Pietinen P, et al. Early introduction of oats associated with decreased risk of persistent asthma and early introduction of fish with decreased risk of allergic rhinitis. Br J Nutr. 2010;103:266-73.

122. Greene LS. Asthma, oxidant stress, and diet. Nutrition. 1999;15(11-12):899-907.

123. Simopoulos AP. Essential fatty acids in health and chronic disease. Am J Clin Nutr. 1999;70(3):560S-569S.

124. Statistics Canada. Canadian Health Measures Survey ( CHMS ) Data User Guide: Cycle 1. 2010. 
125. Statistics Canada. Canadian Health Measures Survey (CHMS) Data User Guide: Cycle 2. 2012.

126. Statistics Canada. Canadian Health Measures Survey (CHMS) Data User Guide: Cycle 3. 2014.

127. Ye M, Beach J, Martin JW, Senthilselvan A. Associations between dietary factors and urinary concentrations of organophosphate and pyrethroid metabolites in a Canadian general population. Int J Hyg Environ Health. 2015;218(7):616-26.

128. Efron B. Second Thoughts On The Bootstrap. 2003.

129. Hankinson JL, Odencrantz JR, Fedan KB. Spirometric Reference Values from a Sample of the General U.S. Population. Am J Respir Crit Care Med. 1999;159:179-87.

130. Corbo GM, Forastiere F, De Sario M, Brunetti L, Bonci E, Bugiani M, et al. Wheeze and asthma in children. Epidemiology. 2008;19(5):747-55.

131. Wickens K, Barry D, Friezema A, Rhodius R, Bone N, Purdie G, et al. Fast foods - are they a risk factor for asthma? Allergy. 2005;60(12):1537-41.

132. Camargo CA, Weiss ST, Zhang S, Willett WC, Speizer FE. Prospective study of body mass index, weight change, and risk of adult-onset asthma in women. Arch Intern Med. 1999;159(21):2582.

133. Shaheen SO, Sterne JAC, Montgomery SM, Azima H. Birth weight, body mass index and asthma in young adults. Thorax. 1999;54:396-402.

134. Jiang R, Jacobs DR, He K, Hoffman E, Hankinson J, Nettleton JA, et al. Associations of dairy intake with CT lung density and lung function. J Am Coll Nutr. 2010;29(5):494- 
502.

135. Bursac Z, Gauss CH, Williams DK, Hosmer DW. Purposeful selection of variables in logistic regression. Source Code Biol Med. 2008;3(1):17.

136. Hosmer DW, Lemeshow S. Interpretation of the fitted logistic regression model. In: Applied Logistic Regression, Second Edition. 2000. p. 47-90.

137. Lawson JA, Janssen I, Bruner MW, Madani K, Pickett W. Urban-rural differences in asthma prevalence among young people in Canada: the roles of health behaviors and obesity. Ann Allergy, Asthma Immunol. 2011;107(3):220-8.

138. LifeLabs (Burnaby reference laboratory). Reference Ranges - Healthcare Providers. 2017.

139. Fischbach F, Dunning M. Manual of Laboratory and Diagnostic Tests. 8th ed. Philadelphia, Pa: Lippincott Williams \& Wilkins. 2008.

140. Okubo H, Shaheen SO, Ntani G, Jameson KA, Syddall HE, Aihie Sayer A, et al. Processed meat consumption and lung function: modification by antioxidants and smoking. Eur Respir J. 2014;43(4):972-82.

141. Noakes M, Keogh JB, Foster PR, Clifton PM. Effect of an energy-restricted, high-protein, low-fat diet relative to a conventional high-carbohydrate, low-fat diet on weight loss, body composition, nutritional status, and markers of cardiovascular health in obese women. Am J Clin Nutr. 2005;81(6):1298-306.

142. Yancy WS, Olsen MK, Guyton JR, Bakst RP, Westman EC. A low-carbohydrate, ketogenic diet versus a low-fat diet to treat obesity and hyperlipidemia. Ann Intern Med. 2004;140(10):769. 
143. Noto H, Goto A, Tsujimoto T, Noda M. Low-carbohydrate diets and all-cause mortality: a systematic review and meta-analysis of observational studies. PLoS One. 2013;8(1):e55030.

144. Wood LG, Garg ML, Gibson PG. A high-fat challenge increases airway inflammation and impairs bronchodilator recovery in asthma. J Allergy Clin Immunol. 2011;127(5):113340.

145. Wood L, Attia J, Mcelduff P, Mcevoy M, Gibson P. Assessment of dietary fat intake and innate immune activation as risk factors for impaired lung function. Eur J Clin Nutr. 2010;64(10):818-25.

146. Mitchell EA, Stewart AW, Clayton T, Asher MI, Ellwood P, Mackay R, et al. Crosssectional survey of risk factors for asthma in 6-7-year-old children in New Zealand: International Study of Asthma and Allergy in Childhood phase three. J Paediatr Child Health. 2009;45(6):375-83.

147. Agrawal S, Pearce N, Ebrahim S. Prevalence and risk factors for self-reported asthma in an adult Indian population : a cross-sectional survey. Int J Tuberc Lung Dis. $2013 ; 17(2): 275-82$.

148. Bakolis I, Hooper R, Thompson RL, Shaheen SO. Dietary patterns and adult asthma: population-based case-control study. Allergy. 2010;65(5):606-15.

149. Wijga AH, Smit HA, Kerkhof M, De Jongste JC, Gerritsen J, Neijens HJ, et al. Association of consumption of products containing milk fat with reduced asthma risk in pre-school children: the PIAMA birth cohort study. Thorax. 2003;58:567-72. 
150. McKeever TM, Lewis SA, Smit HA, Burney P, Cassano PA, Britton J. A multivariate analysis of serum nutrient levels and lung function. Respir Res. 2008;9(1):67.

151. Rasmussen F, Mikkelsen D, Hancox RJ, Lambrechtsen J, Nybo M, Hansen HS, et al. High-sensitive C-reactive protein is associated with reduced lung function in young adults. Eur Respir J. 2008;33(2):382-8.

152. Berry DJ, Hesketh K, Power C, Hyppönen E. Vitamin D status has a linear association with seasonal infections and lung function in British adults. Br J Nutr. 2011;106(9):143340.

153. Tolppanen A-M, Williams D, Henderson J, Lawlor DA. Serum 25-hydroxy-vitamin D and ionised calcium in relation to lung function and allergen skin tests. Eur J Clin Nutr. 2011;65(4):493-500.

154. Wintergerst ES, Maggini S, Hornig DH. Contribution of selected vitamins and trace elements to immune function. Ann Nutr Metab. 2007;51(4):301-23.

155. Hirota S, Helli P, Janssen LJ. Ionic mechanisms and Ca2+ handling in airway smooth muscle. Eur Respir J. 2007;30(1):114-33.

156. Britton J, Pavord I, Richards K, Knox A, Wisniewski A, Weiss S, et al. Dietary sodium intake and the risk of airway hyperreactivity in a random adult population. Thorax. 1994;49:875-80.

157. Gilliland FD. Dietary magnesium, potassium, sodium, and children's lung function. Am J Epidemiol. 2002;155(2):125-31.

158. Hill A. The environment and disease: association or causation? In 1965. p. 295-300. 
159. Raffensperger S, Fanelli Kuczmarski M, Hotchkiss L, Cotugna N, Evans MK, Zonderman AB. Effect of race and predictors of socioeconomic status on diet quality in the HANDLS study sample. J Natl Med Assoc. 2010;102(10):923-30.

160. McHugh ML. Multiple comparison analysis testing in ANOVA. Biochem Medica. 2011;21(3):203-9.

161. Wesolowski SP, Boros PW, Orłowski TM, Quanjer PH. Use the lower limit of normal, not $80 \%$ predicted, in judging eligibility for lung resection. Respiration. 2016;92(2):65-71.

162. Jessri MI, Praneet Ng A, L MR. Adapting the Healthy Eating Index 2010 for the Canadian population: evidence from the Canadian Community Health Survey. Nutrients. 2017;9(910):1-19.

163. Lawson JA, Rennie DC, Dosman JA, Cammer AL, Senthilselvan A. Obesity, diet, and activity in relation to asthma and wheeze among rural dwelling children and adolescents. $\mathbf{J}$ Obes. 2013;2013:1-9. 


\section{Appendix 1}

\section{Variables and Questionnaires:}

1. Age: Age at clinic interview

2. Sex

3. Marital status: What is your marital status? Are you married, living common-law, widowed, separated, divorced, or single, never married?

4. Educational status DHH_ED4: Highest degree, certificate or diploma obtained

5. Has anyone in your immediate family ever had asthma?

6. Smoking: At the present time, do you smoke cigarettes daily, occasionally or not at all? Type of smoker - (D)

7. Exposure to second hand smoke

8. Alcohol drinker: Type of alcohol drinker. Regular, occasional, former, and never.

9. BMI: Calculated from height and weight measurement

10. Physical activities (by activity monitor): An activity monitor is a small battery-operated electronic device that is worn on a belt around the waist, on the right hip bone. The monitor records all daily activities as electronic signals. It is pre-programmed. To start recording tomorrow morning, there is no activation required and it does not need to be turned on or off.

11. Blood measurement

12. Educational status

13. Family income

14. Food frequency questionnaire (per week):

Meat consumption: How often do you usually eat: 
1) Red meat, such as beef, hamburger, pork or lamb?? MFC_B11

2) Liver, including all types of liver such as beef, veal, pork or chicken? MFC_B12

3) Other organ meats such as kidneys, heart or giblets? MFC_B13 (absent in Cycle 3)

4) Beef or pork hot dogs? MFC_B14

5) Sausage or bacon, including all types of sausages such as breakfast, pepperoni and Kielbasa but excluding low-fat, light or turkey varieties? MFC_B15

Egg consumption: How often do you usually eat:

1) Eggs and egg dishes including the yolk (excluding all egg dishes made with only egg whites)? Egg dishes could include such things as eggs, omelette, frittata or quiche. MFC_B19A

2) Eggs and egg dishes that are made with omega-3 enriched eggs? Exclude dishes made with only egg whites. MFC_B19B

Beans and nuts consumption: How often do you usually eat:

1) Cooked dried beans, such as refried beans, baked beans, pea soup or kidney beans, excluding green and yellow beans? MFC_B20

2) Peanuts, walnuts, seeds, or other nuts, excluding nut butters such as peanut butter?

Milk and dairy product consumption: How often do you usually eat:

1) Drink milk or enriched milk substitutes or use them on cereal?

2) Cottage cheese?

3) Yogurt, excluding frozen yogurt?

4) Ice cream or frozen yogurt? 
Grains consumption: How often do you usually eat?

1) Hot or cold cereal? GFV_B11

2) Whole grain bread such as whole wheat, rye or pumpernickel including bread made with oats or buckwheat? Please include bagels, rolls, pita bread or tortillas. GFV_B12

3) White bread, including bagels, rolls, pita bread or tortillas? GFV_B13

4) Any kind of pasta, including spaghetti, noodles, macaroni \& cheese or pasta salad? GFV_B14

5) Any kind of rice? GFV_B14 (absent in Cycle 3)

6) Instant, seasoned or wild rice, such as Minute Rice ${ }^{\circledR}$, Dainty Rice®, or Rice-a-Roni®? GFV_B16

7) Flax seeds, whole or ground, including flax seeds eaten in foods such as breakfast cereal, yogurt, muffins, bread or any other dishes? GFV_B24 (Cycle 3 only)

Fruits consumption: How often do you usually eat?

1) Fruit (fresh, frozen or canned)?

2) Citrus fruit such as oranges or grapefruits, fresh, frozen or canned? GFV_B17A (Cycle 3 only)

3) Strawberries, fresh, frozen or canned, in the summer? GFV_Q17B (Cycle 3 only)

4) Strawberries (fresh, frozen or canned) during the rest of the year? GFV_Q17C (Cycle 3 only)

5) Other types of fruit; fresh, frozen or canned? GFV_B17D (Cycle 3 only)

Vegetables consumption: How often do you usually eat? 
1) Tomatoes or tomato sauce, including salsa, tomato soup and spaghetti sauce but excluding tomato paste, ketchup or pizza sauce? GFV_B18

2) Lettuce or green leafy salad with or without other vegetables? Do not include spinach. GFV_B19

3) Spinach, mustard greens, cabbage or collards, excluding kale? GFV_B20

Potatoes consumption: How often do you usually eat?

1) French fries, home fries, or hash brown potatoes? GFV_B21

2) Other potatoes including baked, boiled, mashed or in potato salad, but excluding sweet potatoes? GFV_B22

Water and soft drink consumption: How often do you usually drink:

1) Water?

2) Diet soft drinks?

3) Regular soft drinks?

4) Sport drinks, such as Gatorade ${ }^{\circledR}$ or Powerade ${ }^{\circledR}$ ?

5) Vitamin-added water, such as Aquafina Plus Vitamins® or Vitamin Water®? Do not include flavoured water or other types of water that are not fortified with vitamins.

6) Orange or grapefruit juice?

7) Other $100 \%$ fruit juices, for example, apple, grape or mixed fruit juice?

8) How often do you usually drink juice with calcium and Vitamin D added?

9) Fruit-flavoured drinks?

10) Vegetable juices?

\section{Dietary fat consumption:}


1) How often do you usually eat? Regular-fat salad dressing or mayonnaise, including on salads and sandwiches? DFC_B11

2) Regular-fat potato chips, tortilla chips or corn chips, excluding low fat chips and pretzels? DFC_B12

3) Margarine? DFC_B13 (Cycle 3)

4) Omega-3 enriched margarine? DFC_B14 (Cycle 3)

\section{Fish and shellfish consumption:}

1) Salt water fish such as salmon, tuna or fish sticks?

2) Fresh water fish such as trout, walleye or pickerel?

3) Shellfish, such as shrimp, mussels, scallops, lobster, clams, oysters or crab? 
Variables and definitions:

\begin{tabular}{|c|c|c|c|c|c|c|}
\hline Variable name & Definition/Question & \multicolumn{4}{|c|}{ Category and code } & Notes \\
\hline Age (CLC_AGE) & Age at clinic interview & & & & & Cycle $1,2,3$ \\
\hline Sex (DHH_SEX) & Gender & \multicolumn{4}{|c|}{$\begin{array}{ll}\text { 1. } & \text { Male: } 1 \\
\text { 2. Female: } 2\end{array}$} & Cycle 1, 2, 3 \\
\hline Height (HWM_11CM) & $\begin{array}{l}\text { Record the standing } \\
\text { height in centimeters. }\end{array}$ & \multicolumn{4}{|c|}{ 2. Female: 2} & Cycle 1, 2, 3 \\
\hline Weight (HWM_13KG) & $\begin{array}{l}\text { When the } \\
\text { measurement is stable, } \\
\text { record the weight in } \\
\text { kilograms. }\end{array}$ & & & & & Cycle 1, 2, 3 \\
\hline BMI (HWMDBMIA) & $\begin{array}{l}\text { BMI norms for } \\
\text { respondents } 18 \text { or } \\
\text { older - (D) }\end{array}$ & \multicolumn{2}{|c|}{$\begin{array}{l}\text { HWMDBMIA Cycle } 1 \text { : } \\
\text { 1. Underweight: } 1 \\
\text { 2. Normal weight: } 2 \\
\text { 3. Overweight: } 3 \\
\text { 4. Obese: } 4 \\
\text { 5. Very obese: } 5 \\
\text { 6. Severely obese: } 6 \\
\text { 7. Not applicable: } 96 \\
\text { 8. Not stated: } 99\end{array}$} & \multicolumn{2}{|c|}{$\begin{array}{l}\text { HWMDBMIA Cycle 2, 3: } \\
\text { 1. Underweight } \\
\text { 2. Normal weight } \\
\text { 3. Overweight } \\
\text { 4. Obese-class I } \\
\text { 5. Obese-class II } \\
\text { 6. Obese-class III } \\
\text { 7. Not applicable: } 96 \\
\text { 8. Not stated: } 99\end{array}$} & $\begin{array}{l}\text { Finally, categorized as: } \\
\begin{array}{l}\text { 1. Obese } \\
\text { 2. Overweight } \\
\text { 3. Not overweight } \\
\text { or obese }\end{array}\end{array}$ \\
\hline $\begin{array}{l}\text { Race/ethnicity } \\
\text { (SDCDCGT) }\end{array}$ & $\begin{array}{l}\text { Cultural or racial } \\
\text { group }\end{array}$ & \multicolumn{2}{|c|}{$\begin{array}{ll}\text { 1. } & \text { White: } 1 \\
\text { 2. } & \text { Black: } 2 \\
\text { 3. } & \text { Korean: } 3 \\
\text { 4. } & \text { Filipino: } 4 \\
\text { 5. Japanese: } 5 \\
\text { 6. Chinese: } 6 \\
\text { 7. South Asian: } 7 \\
\text { 8. Southest Asian: } 8\end{array}$} & \multicolumn{2}{|c|}{$\begin{array}{l}\text { 9. Arab: } 9 \\
\text { 10. West Asian: } 10 \\
\text { 11. Latin American: } 11 \\
\text { 12. Other racial or cultural } \\
\text { origin: } 12 \\
\text { 13. Multiple racial or } \\
\text { cultural origin: } 13 \\
\text { 14. Not applicable: } 96 \\
\text { 15. Not stated: } 99\end{array}$} & $\begin{array}{l}\text { Cycle 1, 2: same } \\
\text { Cycle 3: variable name: } \\
\text { PGDCGT } \\
\text { Finally, categorized as: } \\
\text { 1. Caucasian } \\
\text { 2. other }\end{array}$ \\
\hline Province (DHH_PRN) & $\begin{array}{l}\text { Province of residence } \\
\text { of the respondent }\end{array}$ & Cycle 1: & \multicolumn{2}{|c|}{$\begin{array}{l}\text { Cycle 2: } \\
\text { 1. Newfoundland } \\
\text { and Labrador }\end{array}$} & $\begin{array}{l}\text { Cycle 3: } \\
\text { 1. Nova } \\
\text { scotia: } 12 \\
\end{array}$ & \\
\hline
\end{tabular}




\begin{tabular}{|c|c|c|c|c|c|c|}
\hline & & $\begin{array}{ll}\text { 1. } & \text { New } \\
& \text { Brunswick: } \\
& 13 \\
\text { 2. } & \text { Quebec: } 24 \\
\text { 3. } & \text { Ontario: } 35 \\
\text { 4. } & \text { Alberta: } 48 \\
\text { 5. } & \text { British } \\
& \text { Columbia: } \\
& 59\end{array}$ & \multicolumn{2}{|c|}{$\begin{array}{ll}\text { 2. } & \text { Nova } \\
\text { scotia:12 } \\
\text { 3. } \\
\text { 4. } \text { Onebec } \\
\text { 5. } \text { Manitoba } \\
\text { 6. Alberta } \\
\text { 7. } \\
\text { British } \\
\text { Columbia }\end{array}$} & \begin{tabular}{|ll} 
2. & New \\
& Brunswick: \\
& 13 \\
3. & Quebec: 24 \\
4. & Ontario: 35 \\
5. & Alberta: 48 \\
6. & British \\
& Columbia: \\
& 59
\end{tabular} & \\
\hline $\begin{array}{l}\text { Marital status } \\
\text { (DHH_MS) }\end{array}$ & $\begin{array}{l}\text { What is your marital } \\
\text { status? Are you } \\
\text { married, living } \\
\text { common-law, } \\
\text { widowed, separated, } \\
\text { divorced, or single, } \\
\text { never married? }\end{array}$ & \multicolumn{4}{|c|}{$\begin{array}{l}\text { 1. Married: } 1 \\
\text { 2. Common-law: } 2 \\
\text { 3. Widowed: } 3 \\
\text { 4. Separated: } 4 \\
\text { 5. Divorced: } 5 \\
\text { 6. Single, never married: } 6 \\
\text { 7. Don't know: } 97 \\
\text { 8. Refusal: } 98 \\
\end{array}$} & $\begin{array}{l}\text { Cycle 1, 2, 3: same } \\
\text { Finally, categorized as: } \\
\begin{aligned} \text { 1. Married/common } \\
\text { law } \\
\text { 2. other }\end{aligned}\end{array}$ \\
\hline $\begin{array}{l}\text { Highest level of } \\
\text { education (respondent) } \\
\text { (EDUDR04) }\end{array}$ & & \multicolumn{4}{|c|}{$\begin{array}{l}\text { a) Less than secondary school graduation: } 1 \\
\text { b) Secondary school graduation: } 2 \\
\text { c) Some post-secondary: } 3 \\
\text { d) Post-secondary graduation: } 4 \\
\text { e) Not stated: } 9\end{array}$} & Cycle 1, 2, 3 \\
\hline $\begin{array}{l}\text { Total household } \\
\text { income (INCDHH) }\end{array}$ & $\begin{array}{l}\text { Total household } \\
\text { income from all } \\
\text { sources (amount in } \\
\text { dollars) }\end{array}$ & \multicolumn{2}{|c|}{$\begin{array}{ll}\text { 1. } & \text { No income: } 1 \\
\text { 2. } & <5,000: 2 \\
\text { 3. } & 5,000 \text { to }<10,000: 3 \\
\text { 4. } & 10,000 \text { to }<15,000: 4 \\
\text { 5. } & 15,000 \text { to }<20,000: 5 \\
\text { 6. } & 20,000 \text { to }<30,000: 6\end{array}$} & \multicolumn{2}{|c|}{$\begin{array}{ll}\text { 7. } & 30,000 \text { to }<40,000: 7 \\
\text { 8. } & 40,000 \text { to }<50,000: 8 \\
\text { 9. } 50,000 \text { to }<60,000: 9 \\
\text { 10. } 60,000 \text { to }<80,000: 10 \\
\text { 11. } 80,000 \text { to }<100,000 \text { : } \\
\quad 11 \\
\text { 12. } 100,000 \text { or more: } 12\end{array}$} & 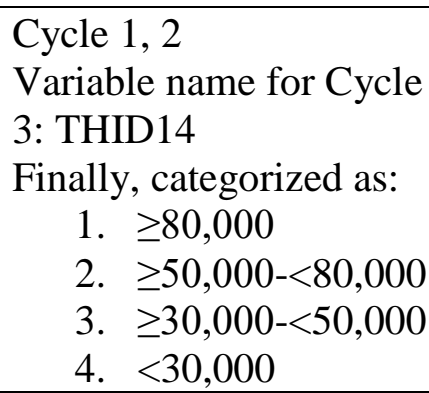 \\
\hline $\begin{array}{l}\text { Physical activity } \\
\text { (mins/d) }\end{array}$ & $\begin{array}{l}\text { a) Average daily light } \\
\text { physical activity }\end{array}$ & $\begin{array}{l}\text { Cycle 1: } \\
\text { Variables } \\
\text { name: }\end{array}$ & \multicolumn{2}{|c|}{$\begin{array}{l}\text { Cycle 2: } \\
\text { Variables name: } \\
\text { AMSDLA }\end{array}$} & $\begin{array}{l}\text { Cycle 3: } \\
\text { Variables name } \\
\text { different: }\end{array}$ & \\
\hline
\end{tabular}




\begin{tabular}{|c|c|c|c|c|c|}
\hline & $\begin{array}{ll}\text { b) Average daily } \\
\text { moderate physical } \\
\text { activity } \\
\text { c) Average daily } \\
\text { mod-to-vig } \\
\text { physical activity } \\
\text { d) Average daily } \\
\text { vigorous physical } \\
\text { activity } \\
\text { e) Average daily } \\
\text { sedentary time } \\
\end{array}$ & $\begin{array}{l}\text { AMSDLA } \\
\text { AMSDMA } \\
\text { AMSDMVA } \\
\text { AMSDVA } \\
\text { AMSDXSA }\end{array}$ & $\begin{array}{l}\text { AMSDMA } \\
\text { AMSDMVA } \\
\text { AMSDVA } \\
\text { AMSDXSA }\end{array}$ & $\begin{array}{l}\text { AMMDLA } \\
\text { AMMDMA } \\
\text { AMMDMVA } \\
\text { AMMDVA } \\
\text { AMMDXSA }\end{array}$ & \\
\hline Smoking (SMKDSTY) & $\begin{array}{l}\text { Type of smoker } \\
\text { Respondents aged } 12 \\
\text { and older }\end{array}$ & \multicolumn{3}{|c|}{$\begin{array}{l}\text { 1. Daily smoker: } 1 \\
\text { 2. Occasional smoker (former daily smoker): } 2 \\
\text { 3. Always an occasional smoker: } 3 \\
\text { 4. Former daily smoker: } 4 \\
\text { 5. Former occasional smoker: } 5 \\
\text { 6. Never smoked: } 6 \\
\text { 7. Not applicable: } 96 \\
\text { 8. Not stated: } 99 \\
\end{array}$} & Cycle $1,2,3$ \\
\hline $\begin{array}{l}\text { Exposure to second } \\
\text { hand smoke (ETS_17) }\end{array}$ & $\begin{array}{l}\text { Exposed to second- } \\
\text { hand smoke - overall } \\
\text { in past month. } \\
\text { Overall, (excluding } \\
\text { your own smoking,) } \\
\text { (and) (excluding inside } \\
\text { your own home), in the } \\
\text { past month were you } \\
\text { exposed to second- } \\
\text { hand smoke: (... every } \\
\text { day, ... almost every } \\
\text { day, ... at least once a } \\
\text { week, ... at least once }\end{array}$ & \multicolumn{3}{|c|}{$\begin{array}{l}\text { 1. Every day: } 1 \\
\text { 2. Almost every day: } 2 \\
\text { 3. At least once a week: } 3 \\
\text { 4. At least once in the past month: } 4 \\
\text { 5. Never: } 5 \\
\text { 6. Don't know: } 7 \\
\text { 7. } \\
\text { Refusal: } 8\end{array}$} & $\begin{array}{l}\text { Cycle 1, } 2 \text { same: } \\
\text { (ETS_17) } \\
\text { Cycle 3: } \\
\text { Variable name ETS_24 }\end{array}$ \\
\hline
\end{tabular}




\begin{tabular}{|c|c|c|c|}
\hline & $\begin{array}{l}\text { in the past month or ... } \\
\text { never)? }\end{array}$ & & \\
\hline $\begin{array}{l}\text { Alcohol drinker } \\
\text { (ALCDTYP) }\end{array}$ & $\begin{array}{l}\text { Type of drinker } \\
\text { Respondents aged } 12 \\
\text { and older }\end{array}$ & $\begin{array}{l}\text { 1. Regular drinker: } 1 \\
\text { 2. Occasional drinker: } 2 \\
\text { 3. Former drinker: } 3 \\
\text { 4. Never drink: } 4 \\
\text { 5. Not applicable: } 6 \\
\text { 6. Not stated: } 9\end{array}$ & Cycle 1, 2, 3 \\
\hline $\begin{array}{l}\text { Chronic respiratory } \\
\text { conditions } \\
\text { (conditions diagnosed by } \\
\text { a health professional): } \\
\text { a) Ever asthma } \\
\text { (CCC_11) } \\
\text { b) Current asthma } \\
\text { (CCC_13) } \\
\text { c) Chronic } \\
\text { bronchitis } \\
\text { (CCC_41) } \\
\text { d) Emphysema } \\
\text { (CCC_43) } \\
\text { e) Chronic } \\
\text { Obstructive } \\
\\
\text { Pulmonary } \\
\text { Disease (COPD) } \\
\text { (CCC_45) }\end{array}$ & $\begin{array}{l}\text { a) Ever asthma: Do } \\
\text { you have asthma? } \\
\text { b) Current asthma: } \\
\text { Have you had any } \\
\text { asthma symptoms } \\
\text { or asthma attacks } \\
\text { in the past } 12 \\
\text { months? } \\
\text { c) Chronic bronchitis: } \\
\text { do you have } \\
\text { chronic bronchitis? } \\
\text { d) Emphysema: Do } \\
\text { you have } \\
\text { emphysema? } \\
\text { Respondents aged } \\
30 \text { and older } \\
\text { e) COPD: Do you } \\
\text { have COPD? } \\
\text { Respondents aged } \\
30 \text { and older }\end{array}$ & $\begin{array}{l}\text { 1. Yes: } 1 \\
\text { 2. No: } 2 \\
\text { 3. Don't know:7 }\end{array}$ & Cycle $1,2,3$ \\
\hline $\begin{array}{l}\text { Family history of } \\
\text { asthma (FMH_23) }\end{array}$ & $\begin{array}{l}\text { Has anyone in your } \\
\text { immediate family ever } \\
\text { had asthma? }\end{array}$ & $\begin{array}{ll}\text { 1. } & \text { Yes: } 1 \\
\text { 2. No: } 2 \\
\text { 3. Not applicable: } 6 \\
\text { 4. Don't know: } 7 \\
\text { 5. } \\
\text { Refusal: } 8\end{array}$ & $\begin{array}{l}\text { Universe } \\
\text { Cycle 1, 2: One } \\
\text { respondent unless } \\
\text { multiple family }\end{array}$ \\
\hline
\end{tabular}




\begin{tabular}{|c|c|c|c|}
\hline & & Cycle 3: yes, no, don't know & $\begin{array}{l}\text { household (1 rep per } \\
\text { family) } \\
\text { Cycle 3: All respondents }\end{array}$ \\
\hline \multicolumn{4}{|c|}{ Dietary variables } \\
\hline $\begin{array}{l}\text { Meats: } \\
\text { Eat red meat } \\
\text { (MFCD11Y) } \\
\text { Eats liver (MFCD12Y) } \\
\text { Other organ meat } \\
\text { (MFC_13N) } \\
\text { Beef or pork hot dogs } \\
\text { (MFCD14Y) } \\
\text { Sausage or bacon } \\
\text { (MFCD15Y) }\end{array}$ & $\begin{array}{l}\text { Eats meat }- \text { total } \\
\text { number of times per } \\
\text { year }\end{array}$ & $\begin{array}{l}\text { The total number of yearly consumption was divided } \\
\text { by } 52 \text { to get the weekly values. Then the weekly } \\
\text { values were divided into tertiles. }\end{array}$ & $\begin{array}{l}\text { Cycle 1, } 2 \text { same } \\
\text { Cycle 3: variable } \\
\text { MFC_13N: not found. }\end{array}$ \\
\hline $\begin{array}{l}\text { Fish: (Cycle 1) } \\
\text { Salt water fish } \\
\text { (MFCD16Y) } \\
\text { Fresh water fish } \\
\text { (MFCD17Y) } \\
\text { Shellfish (MFCD18Y) }\end{array}$ & $\begin{array}{l}\text { Eats fish- total number } \\
\text { of times per year }\end{array}$ & $\begin{array}{l}\text { The total number of yearly consumption was divided } \\
\text { by } 52 \text { to get the weekly values. Then the weekly } \\
\text { values were divided into tertiles. }\end{array}$ & $\begin{array}{l}\text { All three Cycles are } \\
\text { different. }\end{array}$ \\
\hline $\begin{array}{l}\text { Eggs and egg dishes } \\
\text { (MFCD19Y) }\end{array}$ & $\begin{array}{l}\text { Eggs and egg dishes - } \\
\text { total number of times } \\
\text { per year }\end{array}$ & $\begin{array}{l}\text { The total number of yearly consumption was divided } \\
\text { by } 52 \text { to get the weekly values. Then the weekly } \\
\text { values were divided into tertiles. }\end{array}$ & $\begin{array}{l}\text { Cycle 1, 2: same } \\
\text { Cycle 3: different } \\
\text { (MFC_19AN) } \\
\text { Concept Eats } \\
\text { egg/includes the yolk- } \\
\text { reporting period }\end{array}$ \\
\hline $\begin{array}{l}\text { Beans and Nuts: } \\
\text { Cooked dried beans } \\
(\mathrm{MFCD} 20 \mathrm{Y})\end{array}$ & $\begin{array}{l}\text { total number of times } \\
\text { per year }\end{array}$ & $\begin{array}{l}\text { The total number of yearly consumption was divided } \\
\text { by } 52 \text { to get the weekly values. Then the weekly } \\
\text { values were divided into tertiles. }\end{array}$ & $\begin{array}{l}\text { a) MFC_20N: same at } \\
\text { all } 3 \text { Cycles. } \\
\text { b) MFC_21N: } \\
\text { Cycle 1: }\end{array}$ \\
\hline
\end{tabular}




\begin{tabular}{|c|c|c|c|}
\hline $\begin{array}{l}\text { Peanuts, walnuts, seeds } \\
\text { or other nuts } \\
(\text { MFCD21Y) }\end{array}$ & & & $\begin{array}{l}\text { Concept Eats peanuts, } \\
\text { walnuts, seeds or other } \\
\text { nuts -reporting period } \\
\text { Cycle } 2 \& 3 \text { : } \\
\text { Concept Eats nuts - } \\
\text { reporting period }\end{array}$ \\
\hline $\begin{array}{l}\text { Milk: } \\
\text { Drinks milk } \\
\text { (MDCD11Y) } \\
\text { Cottage cheese } \\
\text { (MDCD13Y) } \\
\text { Yogurt (MDCD14Y) } \\
\text { Ice cream or frozen } \\
\text { yogurt (MDCD15Y) }\end{array}$ & $\begin{array}{l}\text { total number of times } \\
\text { per year }\end{array}$ & $\begin{array}{l}\text { The total number of yearly consumption was divided } \\
\text { by } 52 \text { to get the weekly values. Then the weekly } \\
\text { values were divided into tertiles. }\end{array}$ & $\begin{array}{l}\text { a) }(\text { MDC_11N): Cycle } \\
\text { 1, } 2 \text { same. But, } \\
\text { Cycle } 3 \text { different } \\
\text { Cycle 3: variable } \\
\text { MDCD11Y divided into } \\
4 \text { subgroups (otherwise } \\
\text { same): } \\
\text { MDCD01Y } \\
\text { MDCD02Y } \\
\text { MDCD04Y } \\
\text { MDCD05Y }\end{array}$ \\
\hline $\begin{array}{l}\text { Grains: } \\
\text { Hot or cold cereal } \\
\text { (GFVD11Y) } \\
\text { Brown bread } \\
\text { (GFVD12Y) } \\
\text { White bread } \\
\text { (GFVD13Y) } \\
\text { Any kind of Pasta } \\
\text { (GFVD14Y) } \\
\text { Any kind of rice } \\
\text { (GFVD15Y) } \\
\text { Instant, seasoned or wild } \\
\text { rice (GFVD16Y) }\end{array}$ & $\begin{array}{l}\text { total number of times } \\
\text { per year }\end{array}$ & $\begin{array}{l}\text { The total number of yearly consumption was divided } \\
\text { by } 52 \text { to get the weekly values. Then the weekly } \\
\text { values were divided into tertiles. }\end{array}$ & $\begin{array}{l}\text { a) GFV_11N: all } 3 \\
\text { Cycles are same. } \\
\text { b) GFV_15N: } \\
\text { Cycle } 1 \text { \& } 2 \text { : same. But } \\
\text { Cycle 3: variable } \\
\text { GFV_15N not found }\end{array}$ \\
\hline $\begin{array}{l}\text { Fruits: } \\
\text { Eats fruits (GFVD17Y) }\end{array}$ & $\begin{array}{l}\text { total number of times } \\
\text { per year }\end{array}$ & $\begin{array}{l}\text { The total number of yearly consumption was divided } \\
\text { by } 52 \text { to get the weekly values. Then the weekly } \\
\text { values were divided into tertiles. }\end{array}$ & $\begin{array}{l}\text { a) GFVD17Y: } \\
\text { Cycle } 1 \& 2 \text { : same. But } \\
\text { Cycle } 3 \text { different. }\end{array}$ \\
\hline
\end{tabular}




\begin{tabular}{|c|c|c|c|}
\hline & & & $\begin{array}{l}\text { Cycle } 3 \text { has } 4 \text { different } \\
\text { variables for fruits } \\
\text { GFVD17AY } \\
\text { GFVD17BY } \\
\text { GFVD17CY } \\
\text { GFVD17DY } \\
\end{array}$ \\
\hline $\begin{array}{l}\text { Vegetables: } \\
\text { Lettuce or green leafy } \\
\text { salad (GFVD19Y) } \\
\text { Spinach, mustard greens } \\
\text { or collards (GFVD20Y) } \\
\text { Other vegetables } \\
\text { (GFVD23Y) } \\
\text { Tomatoes or tomato } \\
\text { sauce (GFVD18Y) }\end{array}$ & $\begin{array}{l}\text { total number of times } \\
\text { per year }\end{array}$ & $\begin{array}{l}\text { The total number of yearly consumption was divided } \\
\text { by } 52 \text { to get the weekly values. Then the weekly } \\
\text { values were divided into tertiles. }\end{array}$ & $\begin{array}{l}\text { a) GFVD19Y: all 3 } \\
\text { Cycles are same. } \\
\text { b) GFVD20Y: } \\
\text { Cycle 1\&2: Concept } \\
\text { Eats spinach, mustard } \\
\text { greens or collards } \\
\text { Cycle 3: Concept Eats } \\
\text { spinach, mustard greens } \\
\text { or cabbage }\end{array}$ \\
\hline $\begin{array}{l}\text { Potatoes: } \\
\text { French/home fries or } \\
\text { hash brown potatoes } \\
\text { (GFVD21Y) } \\
\text { Other potatoes } \\
\text { (GFVD22Y) }\end{array}$ & $\begin{array}{l}\text { total number of times } \\
\text { per year }\end{array}$ & $\begin{array}{l}\text { The total number of yearly consumption was divided } \\
\text { by } 52 \text { to get the weekly values. Then the weekly } \\
\text { values were divided into tertiles. }\end{array}$ & All 3 Cycles are same. \\
\hline $\begin{array}{l}\text { Dietary fat: } \\
\text { Regular fat salad } \\
\text { dressing (DFCD11Y) } \\
\text { Regular fat potato } \\
\text { chips/tortilla/corn chips } \\
\text { (excluding low fat and } \\
\text { pretzels) (DFCD12Y) }\end{array}$ & $\begin{array}{l}\text { total number of times } \\
\text { per year }\end{array}$ & $\begin{array}{l}\text { The total number of yearly consumption was divided } \\
\text { by } 52 \text { to get the weekly values. Then the weekly } \\
\text { values were divided into tertiles. }\end{array}$ & \\
\hline $\begin{array}{l}\text { Soft drinks: } \\
\text { Drinks regular soft } \\
\text { drinks (WSDD11Y) } \\
\text { Diet soft drinks } \\
\text { (WSDD12Y) }\end{array}$ & $\begin{array}{l}\text { total number of times } \\
\text { per year }\end{array}$ & $\begin{array}{l}\text { The total number of yearly consumption was divided } \\
\text { by } 52 \text { to get the weekly values. Then the weekly } \\
\text { values were divided into tertiles. }\end{array}$ & $\begin{array}{l}\text { Cycle 3: variable name, } \\
\text { WSDD31Y } \\
\text { Cycle 3: variable name, } \\
\text { WSDD30Y }\end{array}$ \\
\hline
\end{tabular}




\begin{tabular}{|c|c|c|c|}
\hline $\begin{array}{l}\text { Sport drinks } \\
\text { (WSDD13Y) }\end{array}$ & & & $\begin{array}{l}\text { Cycle 3: variable name, } \\
\text { WSDD32Y }\end{array}$ \\
\hline $\begin{array}{l}\text { Fruit juices: } \\
\text { Drink fruit juices } \\
\text { (WSDD14Y) } \\
\text { Fruit flavored drinks } \\
\text { (WSDD15Y) } \\
\text { Vegetable juices } \\
\text { (WSDD16Y) }\end{array}$ & $\begin{array}{l}\text { total number of times } \\
\text { per year }\end{array}$ & $\begin{array}{l}\text { The total number of yearly consumption was divided } \\
\text { by } 52 \text { to get the weekly values. Then the weekly } \\
\text { values were divided into tertiles. }\end{array}$ & $\begin{array}{l}\text { Cycle 1\&2: same. But } \\
\text { Cycle } 3 \text { different (no } \\
\text { variable) }\end{array}$ \\
\hline Water (WSDD21Y) & $\begin{array}{l}\text { total number of times } \\
\text { per year }\end{array}$ & $\begin{array}{l}\text { The total number of yearly consumption was divided } \\
\text { by } 52 \text { to get the weekly values. Then the weekly } \\
\text { values were divided into tertiles. }\end{array}$ & $\begin{array}{l}\text { Cycle 1\&2: same. Cycle } \\
3 \text { variable name } \\
\text { different }\end{array}$ \\
\hline \multicolumn{4}{|c|}{ BIOMARKERS } \\
\hline 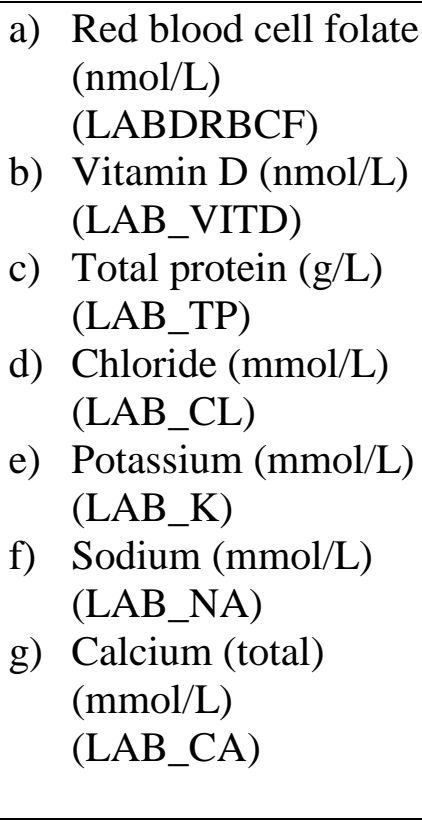 & \multicolumn{3}{|c|}{$\begin{array}{l}\text { a) LABDRBCF: } \\
\text { Same } 1,2,3 \text {. } \\
\text { b) Cycle } 2 \& 3: \\
\text { Concept Vitamin D }[25(\mathrm{OH})](\mathrm{nmol} / \mathrm{L}) \\
\text { Cycle } 3: \text { variable name LAB_VIDS } \\
\text { c) LAB_TP: } \\
\text { Same } 1,2,3 \text {. } \\
\text { d) LAB_CL: } \\
\text { same } 1,2,3 \\
\text { e) LAB_K: same } 1,2,3 \\
\text { f) LAB_NA: same } 1,2,3 \\
\text { g) LAB_CA: same } 1,2,3 \\
\text { h) LAB_CRP: } \\
\text { Cycle } 1: \text { Concept C-reactive protein (mg/L) } \\
\text { Cycle 2, 3: Concept High Sensitivity C reactive protein (mg/L) } \\
\text { i) LAB_B12: same } 1,2,3 \\
\text { j) LAB_HDL: }\end{array}$} \\
\hline
\end{tabular}




\begin{tabular}{|c|c|}
\hline 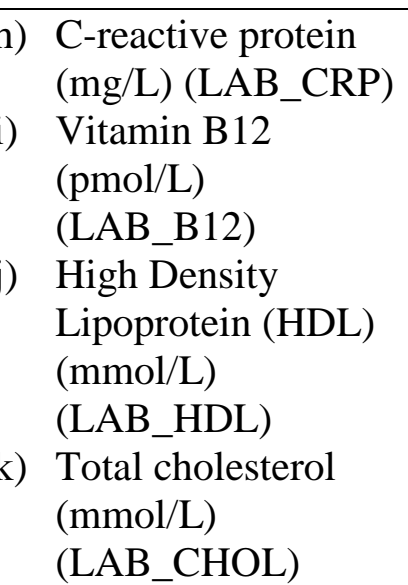 & $\begin{array}{l}\text { Universe: } \\
\text { Cycle 1: Respondents with ATGD12=1 and PHBDELG = } 1 \\
\text { Cycle 2, 3: Respondents with PHBDELG }=1 \\
\text { k) LAB_CHOL: Universe: } \\
\text { Cycle 1: Respondents with ATGD12=1 and PHBDELG = } 1 \\
\text { Cycle 2, 3: Respondents with PHBDELG }=1\end{array}$ \\
\hline
\end{tabular}

\section{Dependent variables:}

\begin{tabular}{|c|c|c|}
\hline Name & Definition & Notes \\
\hline $\begin{array}{l}\mathrm{FEV}_{1} \text { (L) } \\
\text { a) Absolute (SPM_B1) } \\
\text { b) Percent predicted (SPM_PV1) }\end{array}$ & $\begin{array}{l}\text { a) Largest } \mathrm{FEV}_{1}(\mathrm{~L}) \text { from acceptable } \\
\text { trials } \\
\text { b) Respondent's predicted } \mathrm{FEV}_{1}(\mathrm{~L})\end{array}$ & $\begin{array}{l}\text { a) SPM_B1: Universe: } \\
\text { Cycle 1: Respondents with SPM_NUME } \\
>0 \\
\text { Cycle 2, 3: Respondents with SPCDELG } \\
=1\end{array}$ \\
\hline $\begin{array}{l}\text { FVC (L) } \\
\text { a) Absolute (SPM_BFVC) } \\
\text { b) Percent predicted (SPM_PFVC) }\end{array}$ & $\begin{array}{l}\text { a) Largest FVC (L) from acceptable } \\
\text { trials } \\
\text { b) Respondent's predicted FVC (L) }\end{array}$ & $\begin{array}{l}\text { a) SPM_BFVC: } \\
\text { Concept: } \\
\text { Cycle 1: Largest FVC (L) from acceptable } \\
\text { trials } \\
\text { Cycle 2, 3: Largest FVC (L) from } \\
\text { acceptable efforts } \\
\text { Universe: } \\
\text { Cycle 1: Respondents with SPM_NUME } \\
>0 \\
\text { Cycle 2, 3: Respondents with SPCDELG } \\
=1\end{array}$ \\
\hline
\end{tabular}




\begin{tabular}{|c|c|c|}
\hline $\begin{array}{l}\mathrm{FEV}_{1} / \mathrm{FVC}(\%) \\
\text { a) Absolute (SPM_B1F) } \\
\text { b) Predicted (SPM_PV1F) }\end{array}$ & $\begin{array}{l}\text { a) Best } \mathrm{FEV}_{1} / \mathrm{FVC} \text { from acceptable } \\
\text { trials } \\
\text { b) Respondent's predicted } \mathrm{FEV}_{1} / \mathrm{FVC} \\
(\%)\end{array}$ & $\begin{array}{l}\text { a) SPM_B1F: } \\
\text { Concept: } \\
\text { Cycle 1: Best FEV1/FVC from acceptable } \\
\text { trials } \\
\text { Cycle 2, 3: Best FEV1/FVC (\%) from } \\
\text { acceptable efforts } \\
\text { Universe: } \\
\text { Cycle 1: Respondents with SPM_NUME } \\
>0 \\
\text { Cycle 2, 3: Respondents with SPCDELG } \\
=1\end{array}$ \\
\hline $\begin{array}{l}\mathrm{FEF}_{25-75 \%} \\
\text { Absolute }\end{array}$ & 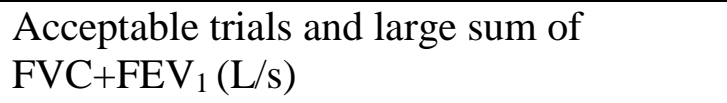 & \\
\hline
\end{tabular}




\section{Appendix 2}

\section{Descriptive statistics by age group:}

Tables 4.1 (Cycle 1), 4.2 (Cycle 2), and 4.3 (Cycle 3) present the demographic, behavioral, and personal factors by age group. There were statistically significant ( $\mathrm{p}$-value $<0.05$ ) differences between age groups for race/ethnicity (Cycles 1, 2, 3), marital status (Cycles 1, 2, 3), educational status (Cycles 1, 2, 3), family income (Cycles 1, 2, 3), height (in Cycles 1, 2, 3), weight (Cycles 1, 2, 3), BMI (Cycles 1, 2, 3), smoking status (Cycles 1,2,3), exposure to second hand smoke (Cycles 1, 2, 3), total physical activity (Cycles 1, 2, 3), sedentary activity (Cycles 1, 2, 3), alcohol drinker (Cycles 1, 2), other respiratory disease (Cycles 1, 3), ever asthma (Cycle 3), current asthma (Cycle 3), and immigrant (Cycle 3). The results were consistent when comparing the Cycles. The following patterns were observed when comparing the age group.

- The proportion of participants who were in "Caucasian" ethnicity increased as the age group increased while the proportion of participants who were in "other" ethnicity decreased as the age group increased (Cycles 1, 2, 3).

- The proportion of participants who were "married/ common law" showed an inverse Ushaped pattern as the age group increased where the highest proportion was in the middle age group. The proportion of participants who were "Widowed, Separated, Divorced, Single, never married" showed a U-shaped pattern as the age group increased (Cycles 1, 2, 3).

- The proportion of participants with a "post-secondary graduation" showed an inverse Ushaped pattern as the age group increased where the highest proportion was in the middle age group (Cycles 1, 2, 3). 
- The proportion of participants with a total family income "CAD $\geq 80,000$ " showed an inverse U-shaped pattern as the age group increased where the highest proportion was in the middle age group (Cycles 1, 2, 3).

- The proportion of participants of mean "height" decreased as the age group increased (Cycles 1, 2, 3).

- The proportion of participants of mean "weight" showed an inverse U-shaped pattern as the age group increased where the highest proportion was in the middle age group (Cycles $1,2,3)$

- The proportion of participants who were "obese" BMI increased as the age group increased (Cycles 1,2) while the proportion of participants who were in "not overweight or obese" BMI decreased as the age group increased (Cycles 1, 2, 3).

- The proportion of participants who were in "daily smoker" smoking status decreased as the age group increased while the proportion of participants in "former smoker" smoking status increased as the age group increased (Cycles 1, 2, 3).

- The proportion of participants who were in "everyday" and "occasional" exposure to second hand smoke decreased as the age group increased while the proportion of participants who were in "never" exposure to second hand smoke increased as the age group increased (Cycles 1, 2, 3).

- The proportion of participants who were in "regular" alcohol drinker decreased as the age group increased (Cycles 1,2).

- The proportion of participants of mean "total activity" showed an inverse U-shaped pattern as the age group increased while the proportion of participants of mean "sedentary activity" increased as the age group increased (Cycles 1, 2, 3). 
Table 4.1: Descriptive statistics (Cycle 1) of socio-demographic, behavioral, and personal characteristics by age groups

\begin{tabular}{|c|c|c|c|c|c|c|}
\hline \multicolumn{2}{|c|}{ Characteristics } & \multirow{2}{*}{$\begin{array}{c}\begin{array}{c}\text { Overall } \\
\%\end{array} \\
49.31 \\
50.69\end{array}$} & \multirow{2}{*}{$\begin{array}{c}\begin{array}{c}\text { Young adult } \\
(=>18 \text { to }<40) \\
\%\end{array} \\
49.83 \\
50.17\end{array}$} & \multirow{2}{*}{$\begin{array}{c}\begin{array}{c}\text { Middle age } \\
(=>40 \text { to }<65) \\
\%\end{array} \\
49.17 \\
50.83\end{array}$} & \multirow{2}{*}{$\begin{array}{c}\begin{array}{c}\text { Older adult } \\
(>=65) \\
\text { \% }\end{array} \\
48.20 \\
51.80\end{array}$} & \multirow{2}{*}{$\begin{array}{c}\text { P-value } \\
0.42\end{array}$} \\
\hline Sex & $\begin{array}{ll}\text { - } & \text { Male } \\
\text { - } & \text { Female }\end{array}$ & & & & & \\
\hline Race/ethnicity & $\begin{array}{l}\text { - Caucasian } \\
\text { - Other }\end{array}$ & $\begin{array}{l}82.29 \\
17.71\end{array}$ & $\begin{array}{l}77.32 \\
22.68\end{array}$ & $\begin{array}{l}84.02 \\
15.98\end{array}$ & $\begin{array}{c}91.60 \\
8.40\end{array}$ & $<0.001$ \\
\hline Immigrant & $\begin{array}{l}\text { - } \mathrm{Yes} \\
\text { - } \mathrm{No}\end{array}$ & $\begin{array}{l}23.26 \\
76.74\end{array}$ & $\begin{array}{l}20.80 \\
79.20\end{array}$ & $\begin{array}{l}24.26 \\
75.74\end{array}$ & $\begin{array}{l}27.28 \\
72.72\end{array}$ & 0.15 \\
\hline Region & $\begin{array}{l}\text { - New Brunswick } \\
\text { - British Columbia } \\
\text { - Ontario } \\
\text { - Alberta } \\
\text { - Quebec }\end{array}$ & $\begin{array}{c}7.21 \\
13.55 \\
38.92 \\
16.73 \\
23.59\end{array}$ & $\begin{array}{c}6.67 \\
13.34 \\
39.50 \\
18.30 \\
22.19\end{array}$ & $\begin{array}{c}7.19 \\
13.68 \\
38.79 \\
15.84 \\
24.51\end{array}$ & $\begin{array}{c}9.02 \\
13.70 \\
37.57 \\
15.12 \\
24.59\end{array}$ & 0.44 \\
\hline Marital status & $\begin{array}{l}\text { - Married/ Common- } \\
\text { law } \\
\text { - Widowed, } \\
\text { Separated, Divorced, } \\
\text { Single, never } \\
\text { married }\end{array}$ & $\begin{array}{l}66.18 \\
33.82\end{array}$ & $\begin{array}{l}53.88 \\
46.12\end{array}$ & $\begin{array}{l}76.37 \\
23.63\end{array}$ & $\begin{array}{l}67.07 \\
32.93\end{array}$ & $<0.001$ \\
\hline $\begin{array}{l}\text { Educational } \\
\text { status }\end{array}$ & $\begin{array}{ll}\text { - } & \text { Post-secondary } \\
\text { graduation } \\
\text { - Some post- } \\
\text { secondary } \\
\text { - Secondary school } \\
\text { graduation } \\
\text { - Less than secondary } \\
\text { school graduation }\end{array}$ & $\begin{array}{c}59.09 \\
9.42 \\
18.76 \\
12.73\end{array}$ & $\begin{array}{c}60.20 \\
13.00 \\
18.72 \\
8.08\end{array}$ & $\begin{array}{c}62.15 \\
6.73 \\
19.32 \\
11.81\end{array}$ & $\begin{array}{c}43.74 \\
7.94 \\
16.77 \\
31.56\end{array}$ & $<0.001$ \\
\hline
\end{tabular}




\begin{tabular}{|c|c|c|c|c|c|c|}
\hline Family income & $\begin{array}{ll}\text { - } & \mathrm{CAD} \geq 80,000 \\
\text { - } & \mathrm{CAD} \geq 50,000 \text { to } \\
& <80,000 \\
\text { - } & \mathrm{CAD} \geq 30,000 \text { to } \\
& <50,000 \\
\text { - } & \mathrm{CAD}<30,000\end{array}$ & $\begin{array}{l}39.97 \\
25.86 \\
18.86 \\
15.31\end{array}$ & $\begin{array}{l}39.39 \\
28.19 \\
17.93 \\
14.49\end{array}$ & $\begin{array}{l}46.42 \\
25.33 \\
15.75 \\
12.51\end{array}$ & $\begin{array}{l}17.66 \\
20.46 \\
33.44 \\
28.44\end{array}$ & $<0.001$ \\
\hline Height & $\begin{array}{ll}\text { - } & \text { Mean }(\mathrm{cm}) / \text { Standard } \\
& \text { error }(\mathrm{SE})\end{array}$ & $168.62 \pm 0.27$ & $170.00 \pm 0.33$ & $168.50 \pm 0.33$ & $164.67 \pm 0.37$ & $<0.001$ \\
\hline Weight & $\begin{array}{l}\text { - Mean (kilogram)/ } \\
\text { Standard error (SE) }\end{array}$ & $77.35 \pm 0.72$ & $75.44 \pm 0.87$ & $79.25 \pm 0.84$ & $76.25 \pm 0.69$ & $<0.001$ \\
\hline BMI & $\begin{array}{ll}\text { - } & \text { Obese } \\
\text { - Overweight } \\
\text { - } \\
\text { Not overweight or } \\
\text { obese }\end{array}$ & $\begin{array}{l}23.92 \\
36.72 \\
39.36\end{array}$ & $\begin{array}{l}19.05 \\
29.68 \\
51.27\end{array}$ & $\begin{array}{l}26.32 \\
41.68 \\
31.10\end{array}$ & $\begin{array}{l}30.05 \\
40.01 \\
29.94\end{array}$ & $<0.001$ \\
\hline Smoking & $\begin{array}{ll}\text { - } & \text { Daily smoker } \\
\text { - } & \text { Former smoker } \\
\text { - } & \text { Never }\end{array}$ & $\begin{array}{l}21.71 \\
29.68 \\
48.62\end{array}$ & $\begin{array}{l}25.10 \\
17.27 \\
57.63\end{array}$ & $\begin{array}{l}21.68 \\
36.22 \\
42.10\end{array}$ & $\begin{array}{l}10.96 \\
44.65 \\
44.38\end{array}$ & $<0.001$ \\
\hline $\begin{array}{l}\text { Exposure to } \\
\text { second hand } \\
\text { smoking }\end{array}$ & $\begin{array}{ll}\text { - } & \text { Every day } \\
\text { - } & \text { Occasional } \\
\text { - } & \text { Never }\end{array}$ & $\begin{array}{l}16.11 \\
36.51 \\
47.38\end{array}$ & $\begin{array}{l}22.70 \\
43.12 \\
34.18\end{array}$ & $\begin{array}{l}13.15 \\
33.69 \\
53.16\end{array}$ & $\begin{array}{c}6.32 \\
26.16 \\
67.53\end{array}$ & $<0.001$ \\
\hline $\begin{array}{l}\text { Alcohol } \\
\text { drinker }\end{array}$ & $\begin{array}{ll}\text { - } & \text { Regular drinker } \\
\text { - } & \text { Occasional drinker } \\
\text { - } & \text { Former drinker } \\
\text { - } & \text { Never drunk }\end{array}$ & $\begin{array}{l}68.69 \\
16.83 \\
8.92 \\
5.57\end{array}$ & $\begin{array}{l}71.18 \\
16.84 \\
6.11 \\
5.88\end{array}$ & $\begin{array}{l}68.80 \\
16.09 \\
9.85 \\
5.25\end{array}$ & $\begin{array}{c}60.34 \\
19.57 \\
14.32 \\
5.77\end{array}$ & 0.004 \\
\hline
\end{tabular}




\begin{tabular}{|c|c|c|c|c|c|c|}
\hline Ever asthma & $\begin{array}{ll}\text { - } & \text { Yes } \\
\text { - } & \text { No }\end{array}$ & $\begin{array}{c}7.63 \\
92.37\end{array}$ & $\begin{array}{c}8.45 \\
91.55\end{array}$ & $\begin{array}{c}6.97 \\
93.03\end{array}$ & $\begin{array}{c}7.52 \\
92.48\end{array}$ & 0.39 \\
\hline Current asthma & $\begin{array}{l}\text { - } \mathrm{Yes} \\
\text { - } \mathrm{No}\end{array}$ & $\begin{array}{c}4.28 \\
95.72\end{array}$ & $\begin{array}{c}4.46 \\
96.54\end{array}$ & $\begin{array}{c}4.41 \\
95.59\end{array}$ & $\begin{array}{c}3.26 \\
95.74\end{array}$ & 0.64 \\
\hline $\begin{array}{l}\text { Obstructive } \\
\text { lung disease } \\
\text { (Chronic } \\
\text { bronchitis, } \\
\text { Emphysema, } \\
\text { COPD) }\end{array}$ & $\begin{array}{ll}\text { - } & \text { Yes } \\
\text { - } & \text { No }\end{array}$ & $\begin{array}{c}3.24 \\
96.76\end{array}$ & $\begin{array}{c}2.87 \\
97.13\end{array}$ & $\begin{array}{c}2.31 \\
97.69\end{array}$ & $\begin{array}{c}7.29 \\
92.71\end{array}$ & $<0.001$ \\
\hline $\begin{array}{l}\text { Family history } \\
\text { of asthma }\end{array}$ & $\begin{array}{l}\text { - } \quad \text { Yes (1) } \\
\text { - } \quad \text { No }(2)\end{array}$ & $\begin{array}{l}22.23 \\
77.77\end{array}$ & $\begin{array}{l}22.02 \\
77.98\end{array}$ & $\begin{array}{l}23.34 \\
76.66\end{array}$ & $\begin{array}{l}18.72 \\
81.28\end{array}$ & 0.21 \\
\hline $\begin{array}{l}\text { Total Physical } \\
\text { activity }\end{array}$ & $\begin{array}{l}\text { - Mean (minutes/day)/ } \\
\text { Standard error (SE) }\end{array}$ & $248.58 \pm 4.44$ & $249.75 \pm 7.04$ & $261.42 \pm 4.61$ & $196.38 \pm 5.83$ & $<0.001$ \\
\hline $\begin{array}{l}\text { Sedentary } \\
\text { activity }\end{array}$ & $\begin{array}{l}\text { - Mean (minutes/day)/ } \\
\text { Standard error (SE) }\end{array}$ & $188.48 \pm 2.81$ & $176.10 \pm 3.59$ & $194.21 \pm 3.10$ & $205.02 \pm 3.11$ & $<0.001$ \\
\hline
\end{tabular}


Table 4.2: Descriptive statistics (Cycle 2) of socio-demographic, behavioral, and personal characteristics by age groups

\begin{tabular}{|c|c|c|c|c|c|c|}
\hline & aracteristics & $\begin{array}{c}\text { Overall } \\
\%\end{array}$ & $\begin{array}{c}\text { Young adult } \\
(=>18 \text { to }<40) \\
\%\end{array}$ & $\begin{array}{c}\text { Middle age } \\
(=>40 \text { to }<65) \\
\%\end{array}$ & $\begin{array}{c}\text { Older adult } \\
(>=65) \\
\%\end{array}$ & P-value \\
\hline Sex & $\begin{array}{ll}\text { - } & \text { Male } \\
\text { - } & \text { Female }\end{array}$ & $\begin{array}{l}49.48 \\
50.52\end{array}$ & $\begin{array}{l}49.82 \\
50.18\end{array}$ & $\begin{array}{l}49.54 \\
50.46\end{array}$ & $\begin{array}{l}48.23 \\
51.77\end{array}$ & 0.57 \\
\hline Race/ethnicity & $\begin{array}{l}\text { - Caucasian } \\
\text { - Other }\end{array}$ & $\begin{array}{l}77.64 \\
22.36\end{array}$ & $\begin{array}{l}71.97 \\
28.03\end{array}$ & $\begin{array}{l}79.28 \\
20.72\end{array}$ & $\begin{array}{l}88.75 \\
11.25\end{array}$ & $<0.001$ \\
\hline Immigrant & $\begin{array}{l}\text { - } \quad \text { Yes } \\
\text { - } \quad \text { No }\end{array}$ & $\begin{array}{l}27.30 \\
72.70\end{array}$ & $\begin{array}{l}26.13 \\
73.87\end{array}$ & $\begin{array}{l}27.56 \\
72.44\end{array}$ & $\begin{array}{l}29.91 \\
70.09\end{array}$ & 0.73 \\
\hline Region & $\begin{array}{l}\text { - Alberta } \\
\text { - British Columbia } \\
\text { - Manitoba } \\
\text { - Ontario } \\
\text { - Newfoundland and } \\
\text { - Labrador } \\
\text { - Nova Scotia } \\
\text { - Quebec }\end{array}$ & $\begin{array}{c}12.70 \\
13.47 \\
4.46 \\
38.83 \\
3.59 \\
3.34 \\
23.61\end{array}$ & $\begin{array}{c}14.77 \\
13.16 \\
4.09 \\
39.08 \\
3.75 \\
2.35 \\
22.81\end{array}$ & $\begin{array}{c}12.31 \\
13.66 \\
4.60 \\
38.33 \\
3.56 \\
3.92 \\
23.63\end{array}$ & $\begin{array}{c}7.92 \\
13.73 \\
5.04 \\
39.89 \\
3.22 \\
4.25 \\
25.96\end{array}$ & 0.68 \\
\hline Marital status & $\begin{array}{l}\text { - Married/ Common-law } \\
\text { Widowed, Separated, } \\
\text { Divorced, Single, never } \\
\text { married }\end{array}$ & $\begin{array}{l}63.95 \\
36.05\end{array}$ & $\begin{array}{l}47.47 \\
52.53\end{array}$ & $\begin{array}{l}75.56 \\
24.44\end{array}$ & $\begin{array}{l}71.29 \\
28.71\end{array}$ & $<0.001$ \\
\hline $\begin{array}{l}\text { Educational } \\
\text { status }\end{array}$ & $\begin{array}{ll}\text { - } & \text { Post-secondary graduation } \\
\text { - } & \text { Some post-secondary } \\
\text { - } & \text { Secondary school } \\
\text { graduation } \\
\text { - } \\
\text { Less than secondary } \\
\text { school graduation }\end{array}$ & $\begin{array}{l}60.22 \\
10.50 \\
15.83 \\
13.45\end{array}$ & $\begin{array}{c}58.79 \\
17.81 \\
13.86 \\
9.54\end{array}$ & $\begin{array}{c}64.95 \\
6.21 \\
17.34 \\
11.50\end{array}$ & $\begin{array}{c}47.61 \\
3.93 \\
16.38 \\
32.09\end{array}$ & $<0.001$ \\
\hline
\end{tabular}




\begin{tabular}{|c|c|c|c|c|c|c|}
\hline Family income & $\begin{array}{ll}\text { - } & \mathrm{CAD} \geq 80,000 \\
\text { - } & \mathrm{CAD} \geq 50,000 \text { to }<80,000 \\
\text { - } & \mathrm{CAD} \geq 30,000 \text { to }<50,000 \\
\text { - } & \mathrm{CAD}<30,000\end{array}$ & $\begin{array}{l}41.14 \\
24.97 \\
17.74 \\
16.15\end{array}$ & $\begin{array}{l}44.45 \\
25.20 \\
13.42 \\
16.92\end{array}$ & $\begin{array}{l}45.03 \\
24.82 \\
18.16 \\
11.99\end{array}$ & $\begin{array}{l}16.94 \\
24.84 \\
29.20 \\
29.02\end{array}$ & $<0.001$ \\
\hline Height & $\begin{array}{l}\text { - Mean }(\mathrm{cm}) / \text { Standard error } \\
(\mathrm{SE})\end{array}$ & $168.45 \pm 0.34$ & $170.32 \pm 0.51$ & $167.84 \pm 0.41$ & $165.02 \pm 0.34$ & $<0.001$ \\
\hline Weight & $\begin{array}{l}\text { - Mean (kilogram)/ } \\
\text { Standard error }(\mathrm{SE})\end{array}$ & $77.61 \pm 0.92$ & $75.24 \pm 1.38$ & $79.49 \pm 0.92$ & $77.89 \pm 0.67$ & $<0.001$ \\
\hline BMI & $\begin{array}{l}\text { - } \text { Obese } \\
\text { - Overweight } \\
\text { - } \quad \text { Not overweight or obese }\end{array}$ & $\begin{array}{l}26.23 \\
34.22 \\
39.55\end{array}$ & $\begin{array}{l}18.69 \\
28.45 \\
52.86\end{array}$ & $\begin{array}{l}29.86 \\
37.87 \\
32.27\end{array}$ & $\begin{array}{l}35.28 \\
37.99 \\
26.73\end{array}$ & $<0.001$ \\
\hline Smoking & $\begin{array}{ll}\text { - } & \text { Daily smoker } \\
\text { - } & \text { Former smoker } \\
\text { - } & \text { Never }\end{array}$ & $\begin{array}{l}20.65 \\
28.73 \\
50.62\end{array}$ & $\begin{array}{l}22.63 \\
19.05 \\
58.32\end{array}$ & $\begin{array}{l}21.26 \\
31.04 \\
47.70\end{array}$ & $\begin{array}{l}12.44 \\
49.65 \\
37.91\end{array}$ & $<0.001$ \\
\hline $\begin{array}{l}\text { Exposure to } \\
\text { second hand } \\
\text { smoking }\end{array}$ & $\begin{array}{ll}\text { - } & \text { Every day } \\
\text { - } & \text { Occasional } \\
\text { - } & \text { Never }\end{array}$ & $\begin{array}{l}15.71 \\
38.81 \\
45.49\end{array}$ & $\begin{array}{l}18.76 \\
48.52 \\
32.72\end{array}$ & $\begin{array}{l}16.07 \\
33.68 \\
50.25\end{array}$ & $\begin{array}{c}5.21 \\
28.23 \\
66.56\end{array}$ & $<0.001$ \\
\hline Alcohol drinker & $\begin{array}{ll}\text { - } & \text { Regular drinker } \\
\text { - } & \text { Occasional drinker } \\
\text { - } & \text { Former drinker } \\
\text { - } & \text { Never drunk }\end{array}$ & $\begin{array}{c}67.11 \\
15.47 \\
10.53 \\
6.89\end{array}$ & $\begin{array}{c}69.18 \\
14.48 \\
6.85 \\
9.49\end{array}$ & $\begin{array}{c}66.59 \\
16.53 \\
12.24 \\
4.63\end{array}$ & $\begin{array}{c}62.74 \\
14.60 \\
15.40 \\
7.26\end{array}$ & 0.003 \\
\hline Ever asthma & $\begin{array}{ll}\text { - } & \text { Yes } \\
\text { - } & \text { No }\end{array}$ & $\begin{array}{l}10.07 \\
89.93\end{array}$ & $\begin{array}{l}11.85 \\
88.15\end{array}$ & $\begin{array}{c}9.34 \\
90.66\end{array}$ & $\begin{array}{c}7.37 \\
92.63\end{array}$ & 0.43 \\
\hline
\end{tabular}




\begin{tabular}{|c|c|c|c|c|c|c|}
\hline Current asthma & $\begin{array}{ll}\text { - } & \text { Yes } \\
\text { - } & \text { No }\end{array}$ & $\begin{array}{c}4.54 \\
95.46\end{array}$ & $\begin{array}{c}4.32 \\
95.68\end{array}$ & $\begin{array}{c}4.99 \\
95.01\end{array}$ & $\begin{array}{c}3.59 \\
96.41\end{array}$ & 0.67 \\
\hline $\begin{array}{l}\text { Obstructive lung } \\
\text { disease (Chronic } \\
\text { bronchitis, } \\
\text { Emphysema, } \\
\text { COPD) }\end{array}$ & $\begin{array}{ll}\text { - } & \text { Yes } \\
\text { - } & \text { No }\end{array}$ & $\begin{array}{c}4.22 \\
95.78\end{array}$ & $\begin{array}{c}3.62 \\
96.38\end{array}$ & $\begin{array}{c}3.98 \\
96.02\end{array}$ & $\begin{array}{c}5.87 \\
94.13\end{array}$ & 0.48 \\
\hline $\begin{array}{l}\text { Family history of } \\
\text { asthma }\end{array}$ & $\begin{array}{l}\text { - } \mathrm{Yes} \\
\text { - } \mathrm{No}\end{array}$ & $\begin{array}{l}23.65 \\
76.35\end{array}$ & $\begin{array}{l}24.61 \\
75.39\end{array}$ & $\begin{array}{l}24.42 \\
75.58\end{array}$ & $\begin{array}{l}17.87 \\
82.13\end{array}$ & 0.37 \\
\hline $\begin{array}{l}\text { Total Physical } \\
\text { activity }\end{array}$ & $\begin{array}{l}\text { - Mean (minutes/day)/ } \\
\text { Standard error (SE) }\end{array}$ & $217.47 \pm 4.55$ & $220.28 \pm 6.94$ & $228.88 \pm 4.15$ & $168.26 \pm 4.71$ & $<0.001$ \\
\hline $\begin{array}{l}\text { Sedentary } \\
\text { activity }\end{array}$ & $\begin{array}{l}\text { - Mean (minutes/day)/ } \\
\text { Standard error (SE) }\end{array}$ & $493.80 \pm 4.83$ & $456.51 \pm 7.34$ & $512.04 \pm 6.87$ & $536.72 \pm 7.38$ & $<0.001$ \\
\hline
\end{tabular}


Table 4.3: Descriptive statistics (Cycle 3) of socio-demographic, behavioral, and personal characteristics by age groups

\begin{tabular}{|c|c|c|c|c|c|c|}
\hline & Characteristics & $\begin{array}{c}\text { Overall } \\
\%\end{array}$ & $\begin{array}{c}\text { Young adult } \\
(=>18 \text { to }<40) \\
\%\end{array}$ & $\begin{array}{c}\text { Middle age } \\
(=>40 \text { to } \\
<65) \\
\%\end{array}$ & $\begin{array}{c}\text { Older adult } \\
\begin{array}{c}(>=65) \\
\%\end{array}\end{array}$ & P-value \\
\hline Sex & $\begin{array}{ll}\text { - } & \text { Male } \\
\text { - } & \text { Female }\end{array}$ & $\begin{array}{l}49.64 \\
50.36\end{array}$ & $\begin{array}{l}50.38 \\
49.62\end{array}$ & $\begin{array}{l}49.58 \\
50.42\end{array}$ & $\begin{array}{l}47.74 \\
52.26\end{array}$ & 0.23 \\
\hline Race/ethnicity & $\begin{array}{l}\text { - Caucasian } \\
\text { - Other }\end{array}$ & $\begin{array}{l}75.13 \\
24.87\end{array}$ & $\begin{array}{l}70.90 \\
29.10\end{array}$ & $\begin{array}{l}75.59 \\
24.41\end{array}$ & $\begin{array}{l}85.67 \\
14.33\end{array}$ & 0.003 \\
\hline Immigrant & $\begin{array}{l}\text { - } \quad \text { Yes } \\
\text { - } \mathrm{No}\end{array}$ & $\begin{array}{l}27.54 \\
72.46\end{array}$ & $\begin{array}{l}22.48 \\
77.52\end{array}$ & $\begin{array}{l}30.04 \\
69.96\end{array}$ & $\begin{array}{l}33.50 \\
66.50\end{array}$ & 0.004 \\
\hline Region & $\begin{array}{ll}\text { - } & \text { New Brunswick } \\
\text { - } & \text { British Columbia } \\
\text { - } & \text { Ontario } \\
\text { - } & \text { Alberta } \\
\text { - Nova Scotia } \\
\text { - } \\
\text { Quebec }\end{array}$ & $\begin{array}{c}3.41 \\
13.54 \\
39.24 \\
17.23 \\
3.37 \\
23.21\end{array}$ & $\begin{array}{c}1.55 \\
13.40 \\
39.81 \\
18.98 \\
4.24 \\
22.02\end{array}$ & $\begin{array}{c}3.98 \\
13.61 \\
39.44 \\
16.53 \\
3.00 \\
23.44\end{array}$ & $\begin{array}{c}6.76 \\
13.68 \\
36.92 \\
14.62 \\
2.17 \\
25.85\end{array}$ & 0.72 \\
\hline Marital status & $\begin{array}{l}\text { - Married/ Common-law } \\
\text { Widowed, Separated, } \\
\text { Divorced, Single, never } \\
\text { married }\end{array}$ & $\begin{array}{l}62.93 \\
37.07\end{array}$ & $\begin{array}{l}45.48 \\
54.52\end{array}$ & $\begin{array}{l}75.88 \\
24.12\end{array}$ & $\begin{array}{l}68.43 \\
31.57\end{array}$ & $<0.001$ \\
\hline $\begin{array}{l}\text { Educational } \\
\text { status }\end{array}$ & 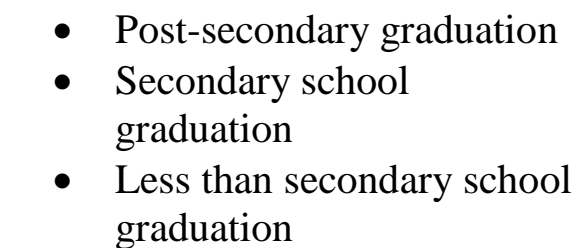 & $\begin{array}{l}62.31 \\
25.02 \\
12.67\end{array}$ & $\begin{array}{c}61.34 \\
30.35 \\
8.31\end{array}$ & $\begin{array}{l}66.10 \\
22.63 \\
11.27\end{array}$ & $\begin{array}{l}51.93 \\
18.24 \\
29.83\end{array}$ & $<0.001$ \\
\hline
\end{tabular}




\begin{tabular}{|c|c|c|c|c|c|c|}
\hline Family income & $\begin{array}{ll}\text { - } & \mathrm{CAD} \geq 80,000 \\
\text { - } & \mathrm{CAD} \geq 50,000 \text { to }<80,000 \\
\text { - } & \mathrm{CAD} \geq 30,000 \text { to }<50,000 \\
\text { - } & \mathrm{CAD}<30,000\end{array}$ & $\begin{array}{l}41.58 \\
23.02 \\
20.34 \\
15.06\end{array}$ & $\begin{array}{l}38.48 \\
24.95 \\
22.57 \\
14.00\end{array}$ & $\begin{array}{l}49.81 \\
20.18 \\
16.43 \\
13.58\end{array}$ & $\begin{array}{l}22.18 \\
27.25 \\
27.37 \\
23.20\end{array}$ & $<0.001$ \\
\hline Height & $\begin{array}{l}\text { - Mean }(\mathrm{cm}) / \text { Standard error } \\
(\mathrm{SE})\end{array}$ & $168.91 \pm 0.40$ & $170.58 \pm 0.49$ & $168.67 \pm 0.36$ & $164.94 \pm 0.83$ & $<0.001$ \\
\hline Weight & $\begin{array}{l}\text { - Mean (kilogram)/ Standard } \\
\text { error (SE) }\end{array}$ & $78.35 \pm 1.16$ & $77.09 \pm 1.61$ & $79.96 \pm 1.24$ & $76.42 \pm 1.25$ & $<0.001$ \\
\hline BMI & $\begin{array}{ll}\text { - } & \text { Obese } \\
\text { - } & \text { Overweight } \\
\text { - } & \text { Not overweight or obese }\end{array}$ & $\begin{array}{l}26.39 \\
35.60 \\
38.00\end{array}$ & $\begin{array}{l}21.48 \\
31.14 \\
47.38\end{array}$ & $\begin{array}{l}30.56 \\
34.96 \\
34.47\end{array}$ & $\begin{array}{l}26.02 \\
50.44 \\
23.54\end{array}$ & $<0.001$ \\
\hline Smoking & $\begin{array}{ll}\text { - } & \text { Daily smoker } \\
\text { - } & \text { Former smoker } \\
\text { - } & \text { Never }\end{array}$ & $\begin{array}{l}22.92 \\
26.10 \\
50.97\end{array}$ & $\begin{array}{l}25.72 \\
15.40 \\
58.88\end{array}$ & $\begin{array}{l}23.61 \\
30.33 \\
46.06\end{array}$ & $\begin{array}{l}12.52 \\
42.31 \\
45.17\end{array}$ & $<0.001$ \\
\hline $\begin{array}{l}\text { Exposure to } \\
\text { second hand } \\
\text { smoking }\end{array}$ & $\begin{array}{ll}\text { - } & \text { Every day } \\
\text { - } & \text { Occasional } \\
\text { - } & \text { Never }\end{array}$ & $\begin{array}{l}22.48 \\
37.59 \\
39.94\end{array}$ & $\begin{array}{l}31.10 \\
39.16 \\
29.74\end{array}$ & $\begin{array}{l}20.07 \\
38.32 \\
41.61\end{array}$ & $\begin{array}{c}6.03 \\
30.58 \\
63.39\end{array}$ & $<0.001$ \\
\hline $\begin{array}{l}\text { Alcohol } \\
\text { drinker }\end{array}$ & $\begin{array}{ll}\text { - } & \text { Regular drinker } \\
\text { - Occasional drinker } \\
\text { - Former drinker } \\
\text { - Never drunk }\end{array}$ & $\begin{array}{c}69.68 \\
12.77 \\
9.91 \\
7.63\end{array}$ & $\begin{array}{l}69.99 \\
12.13 \\
9.33 \\
8.54\end{array}$ & $\begin{array}{c}71.82 \\
12.84 \\
8.41 \\
6.93\end{array}$ & $\begin{array}{c}61.45 \\
14.34 \\
16.74 \\
7.47\end{array}$ & 0.15 \\
\hline Ever asthma & $\begin{array}{ll}\text { - } & \text { Yes } \\
\text { - } & \text { No }\end{array}$ & $\begin{array}{c}9.35 \\
90.65\end{array}$ & $\begin{array}{l}13.47 \\
86.53\end{array}$ & $\begin{array}{c}6.51 \\
93.49\end{array}$ & $\begin{array}{c}7.32 \\
92.68\end{array}$ & 0.014 \\
\hline
\end{tabular}




\begin{tabular}{|c|c|c|c|c|c|c|}
\hline Current asthma & $\begin{array}{ll}\text { - } & \text { Yes } \\
\text { - } & \text { No }\end{array}$ & $\begin{array}{c}4.44 \\
95.56\end{array}$ & $\begin{array}{c}6.80 \\
93.20\end{array}$ & $\begin{array}{c}3.25 \\
96.75\end{array}$ & $\begin{array}{c}1.80 \\
98.20\end{array}$ & 0.015 \\
\hline $\begin{array}{l}\text { Obstructive } \\
\text { lung disease } \\
\text { (Chronic } \\
\text { bronchitis, } \\
\text { Emphysema, } \\
\text { COPD) }\end{array}$ & $\begin{array}{ll}\text { - } & \text { Yes } \\
\text { - } & \text { No }\end{array}$ & $\begin{array}{c}2.98 \\
97.02\end{array}$ & $\begin{array}{c}0.67 \\
99.33\end{array}$ & $\begin{array}{c}3.03 \\
96.97\end{array}$ & $\begin{array}{c}5.83 \\
94.17\end{array}$ & $<0.001$ \\
\hline $\begin{array}{l}\text { Family history } \\
\text { of asthma }\end{array}$ & $\begin{array}{l}\text { - } \quad \text { Yes } \\
\text { - } \mathrm{No}\end{array}$ & $\begin{array}{l}21.98 \\
78.02\end{array}$ & $\begin{array}{l}22.00 \\
78.00\end{array}$ & $\begin{array}{l}23.04 \\
76.96\end{array}$ & $\begin{array}{l}18.23 \\
81.77\end{array}$ & 0.62 \\
\hline $\begin{array}{l}\text { Total Physical } \\
\text { activity }\end{array}$ & $\begin{array}{l}\text { - Mean (minutes/day)/ } \\
\text { Standard error (SE) }\end{array}$ & $228.33 \pm 6.40$ & $228.46 \pm 10.78$ & $241.94 \pm 5.69$ & $180.30 \pm 9.00$ & $<0.001$ \\
\hline $\begin{array}{l}\text { Sedentary } \\
\text { activity }\end{array}$ & $\begin{array}{l}\text { - Mean (minutes/day)/ } \\
\text { Standard error (SE) }\end{array}$ & $502.55 \pm 4.92$ & $450.27 \pm 7.31$ & $532.04 \pm 7.08$ & $547.87 \pm 6.57$ & $<0.001$ \\
\hline
\end{tabular}


Tables $4.4,4.5$, and 4.6 show the distribution of dietary consumption by age group. The relationship between dietary factors and age group were statistically significant ( $\mathrm{p}$-value <0.05) for meats (Cycles 1, 2, 3), grains (Cycles 1, 2, 3), fruits (Cycles 1, 2, 3), potatoes (Cycles 1, 2, 3), milk (Cycles 1, 2), dietary fat (Cycles 1, 2), soft drinks (Cycles 1, 2), fishes (Cycles 2, 3), and water (Cycles 1, 3), beans (Cycle 1), vegetables (Cycle 1). The following patterns were observed:

- The proportion of participants who consumed low amount of meats increased as age group increased while the proportion of participants who consumed higher meats decreased as the age group increased (Cycles 1, 2, 3).

- The proportion of participants who consumed low (Cycles 1, 2, 3) and medium (Cycle 3) amount of fish decreased as age group increased. However, the proportion of participants who consumed high (Cycles 1, 2, 3) and medium (Cycles 1,2) amount of fish increased as the age group increased.

- The proportion of participants who consumed low (Cycles 1, 2) and medium (Cycle 2) amount of beans decreased as the age group increased. However, in Cycles 1, 2, and 3 the proportion participants who consumed high amount increased as the age group increased.

- The proportion of participants who consumed medium amount of milk increased as the age group increased in Cycle 2.

- The proportion of participants who consumed medium (Cycle 2) and high (Cycle 3) amount of grains increased as the age group increased. However, the proportion of participants who consumed medium (Cycle 3) and high (Cycle 2) amount decreased as the age group increased. 
- The proportion of participants who consumed low (Cycles 1, 2, 3) amount of fruits decreased as the age group increased. However, the proportion of participants who consumed high (Cycles 1, 2, 3) amount increased as the age group increased.

- The proportion of participants who consumed low (Cycles 1, 2, 3) amount of vegetables decreased as the age group increased. However, the proportion of participants who consumed medium (Cycles 2) amount increased as the age group increased.

- The proportion of participants who consumed low (Cycle 1) and medium (Cycles 2, 3) amount of potatoes decreased as the age group increased. However, the proportion of participants who consumed high (Cycle 3) amount increased as the age group increased.

- The proportion of participants who consumed low amount of dietary fat (Cycles 1,2$)$ increased as the age group increased. However, the proportion of participants who consumed medium (Cycles 1,2) and higher (Cycle 1) amount decreased as the age group increased.

- The proportion of participants who consumed lower (Cycles 1, 2, 3) amount of soft drinks increased as the age group increased. However, in Cycles 1, 2, and 3 the proportion of participants who consumed medium and high amount decreased as the age group increased.

- The proportion of participants who consumed low (Cycles 1, 3) and medium (Cycle 2) amount of water increased as the age group increased. However, in Cycles 1, 2, and 3 the proportion of participants who consumed higher amount decreased as the age group increased. 
Table 4.4: Descriptive statistics (Cycle 1) of dietary factors (tertiles) by age group

\begin{tabular}{|c|c|c|c|c|c|c|}
\hline Dietary factors & $\begin{array}{c}\text { Tertiles } \\
\text { Times/week }\end{array}$ & $\begin{array}{c}\text { Overall } \\
\%\end{array}$ & $\begin{array}{c}\text { Young adult } \\
(=>18 \text { to }<40) \\
\%\end{array}$ & $\begin{array}{c}\text { Middle age } \\
(=>40 \text { to }<65) \\
\%\end{array}$ & $\begin{array}{c}\text { Older adult } \\
\begin{array}{c}(>=65) \\
\%\end{array}\end{array}$ & P-value \\
\hline Red meat & $\begin{array}{ll}\text { - } & \text { Low } \\
\text { - } & \text { Medium } \\
\text { - } & \text { High }\end{array}$ & $\begin{array}{l}32.97 \\
31.55 \\
35.48\end{array}$ & $\begin{array}{l}29.37 \\
29.61 \\
41.02\end{array}$ & $\begin{array}{l}35.13 \\
32.89 \\
31.99\end{array}$ & $\begin{array}{l}36.32 \\
32.73 \\
30.95\end{array}$ & 0.001 \\
\hline Fish & $\begin{array}{ll}\text { - } & \text { Low } \\
\text { - } & \text { Medium } \\
\text { - } & \text { High }\end{array}$ & $\begin{array}{l}33.61 \\
31.11 \\
35.28\end{array}$ & $\begin{array}{l}38.00 \\
28.55 \\
33.45\end{array}$ & $\begin{array}{l}30.93 \\
32.67 \\
36.40\end{array}$ & $\begin{array}{l}29.72 \\
33.38 \\
36.90\end{array}$ & 0.027 \\
\hline Eggs and eggs dishes & $\begin{array}{ll}\text { - } & \text { Low } \\
\text { - } & \text { Medium } \\
\text { - } & \text { High }\end{array}$ & $\begin{array}{l}24.67 \\
26.82 \\
48.51\end{array}$ & $\begin{array}{l}23.87 \\
25.63 \\
50.50\end{array}$ & $\begin{array}{l}25.27 \\
27.90 \\
46.83\end{array}$ & $\begin{array}{l}24.94 \\
26.54 \\
48.52\end{array}$ & 0.79 \\
\hline Beans and nuts & $\begin{array}{ll}\text { - } & \text { Low } \\
\text { - } & \text { Medium } \\
\text { - } & \text { High }\end{array}$ & $\begin{array}{l}31.36 \\
36.35 \\
32.30\end{array}$ & $\begin{array}{l}32.24 \\
40.77 \\
26.98\end{array}$ & $\begin{array}{l}31.30 \\
33.34 \\
35.36\end{array}$ & $\begin{array}{l}28.76 \\
33.55 \\
37.70\end{array}$ & 0.001 \\
\hline Milk and dairy products & $\begin{array}{ll}\text { - } & \text { Low } \\
\text { - } & \text { Medium } \\
\text { - } & \text { High }\end{array}$ & $\begin{array}{l}33.89 \\
33.05 \\
33.05\end{array}$ & $\begin{array}{l}30.41 \\
32.53 \\
37.06\end{array}$ & $\begin{array}{l}36.47 \\
33.65 \\
29.88\end{array}$ & $\begin{array}{l}35.31 \\
32.46 \\
32.23\end{array}$ & 0.045 \\
\hline Grains & $\begin{array}{ll}\text { - } & \text { Low } \\
\text { - } & \text { Medium } \\
\text { - } & \text { High }\end{array}$ & $\begin{array}{l}33.66 \\
32.83 \\
33.50\end{array}$ & $\begin{array}{l}29.34 \\
31.38 \\
39.27\end{array}$ & $\begin{array}{l}37.05 \\
34.12 \\
28.82\end{array}$ & $\begin{array}{l}34.67 \\
32.61 \\
32.72\end{array}$ & $<0.001$ \\
\hline Fruits & $\begin{array}{ll}\text { - } & \text { Low } \\
\text { - } & \text { Medium } \\
\text { - } & \text { High }\end{array}$ & $\begin{array}{l}30.04 \\
38.65 \\
31.31\end{array}$ & $\begin{array}{l}33.49 \\
39.51 \\
27.00\end{array}$ & $\begin{array}{l}28.74 \\
37.18 \\
34.08\end{array}$ & $\begin{array}{l}23.94 \\
41.41 \\
34.66\end{array}$ & 0.023 \\
\hline
\end{tabular}




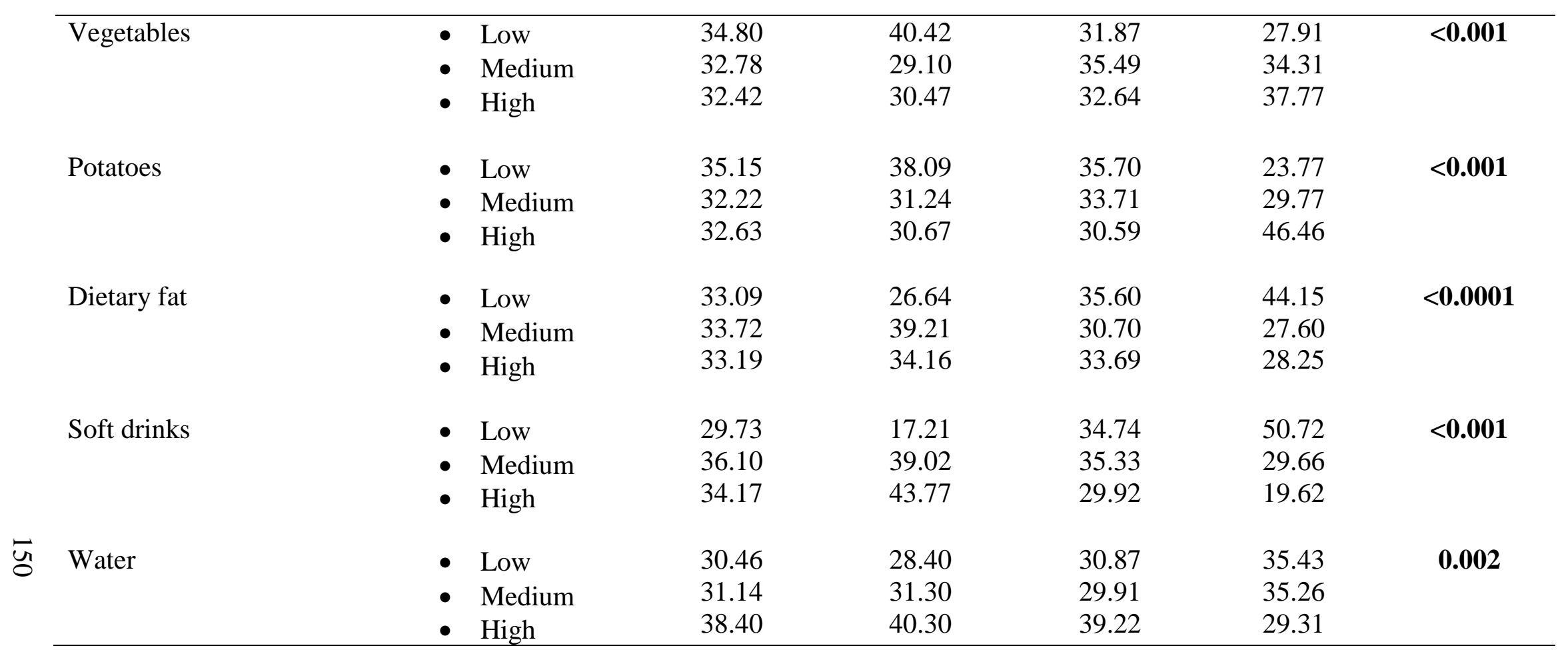

Bold text indicates statistical significance 
Table 4.5: Descriptive statistics (Cycle 2) of dietary factors (tertiles) by age group

\begin{tabular}{|c|c|c|c|c|c|c|}
\hline Dietary factors & $\begin{array}{c}\text { Tertiles } \\
\text { Times/week }\end{array}$ & $\begin{array}{c}\text { Overall } \\
\%\end{array}$ & $\begin{array}{c}\text { Young adult } \\
(=>18 \text { to }<40) \\
\%\end{array}$ & $\begin{array}{c}\text { Middle age } \\
(=>40 \text { to }<65) \\
\%\end{array}$ & $\begin{array}{c}\text { Older adult } \\
\begin{array}{c}(>=65) \\
\%\end{array}\end{array}$ & P-value \\
\hline Red meat & $\begin{array}{ll}\text { - } & \text { Low } \\
\text { - } & \text { Medium } \\
\text { - } & \text { High }\end{array}$ & $\begin{array}{l}32.42 \\
31.33 \\
36.25\end{array}$ & $\begin{array}{l}26.68 \\
28.20 \\
45.11\end{array}$ & $\begin{array}{l}34.54 \\
33.53 \\
31.93\end{array}$ & $\begin{array}{l}41.96 \\
32.74 \\
25.30\end{array}$ & $<0.001$ \\
\hline Fish & $\begin{array}{ll}\text { - } & \text { Low } \\
\text { - } & \text { Medium } \\
\text { - } & \text { High }\end{array}$ & $\begin{array}{l}31.01 \\
33.32 \\
35.66\end{array}$ & $\begin{array}{l}38.64 \\
31.40 \\
29.96\end{array}$ & $\begin{array}{l}26.43 \\
34.10 \\
39.48\end{array}$ & $\begin{array}{l}24.75 \\
36.31 \\
38.94\end{array}$ & $<0.001$ \\
\hline Eggs and eggs dishes & $\begin{array}{ll}\text { - } & \text { Low } \\
\text { - } & \text { Medium } \\
\text { - } & \text { High }\end{array}$ & $\begin{array}{l}20.98 \\
24.58 \\
54.43\end{array}$ & $\begin{array}{l}20.48 \\
23.31 \\
56.21\end{array}$ & $\begin{array}{l}21.22 \\
24.78 \\
54.00\end{array}$ & $\begin{array}{l}21.66 \\
27.70 \\
50.65\end{array}$ & 0.62 \\
\hline Beans and nuts & $\begin{array}{ll}\text { - } & \text { Low } \\
\text { - } & \text { Medium } \\
\text { - } & \text { High }\end{array}$ & $\begin{array}{l}30.49 \\
32.80 \\
36.70\end{array}$ & $\begin{array}{l}32.64 \\
31.49 \\
35.86\end{array}$ & $\begin{array}{l}29.46 \\
33.87 \\
36.68\end{array}$ & $\begin{array}{l}27.78 \\
32.88 \\
39.35\end{array}$ & 0.65 \\
\hline Milk and dairy products & $\begin{array}{ll}\text { - } & \text { Low } \\
\text { - } & \text { Medium } \\
\text { - High }\end{array}$ & $\begin{array}{l}37.26 \\
32.14 \\
30.60\end{array}$ & $\begin{array}{l}35.96 \\
29.17 \\
34.87\end{array}$ & $\begin{array}{l}40.03 \\
32.26 \\
27.71\end{array}$ & $\begin{array}{l}31.11 \\
40.64 \\
28.25\end{array}$ & 0.006 \\
\hline Grains & $\begin{array}{ll}\text { - } & \text { Low } \\
\text { - } & \text { Medium } \\
\text { - } & \text { High }\end{array}$ & $\begin{array}{l}33.07 \\
31.30 \\
35.63\end{array}$ & $\begin{array}{l}28.15 \\
30.46 \\
41.39\end{array}$ & $\begin{array}{l}36.42 \\
31.67 \\
31.91\end{array}$ & $\begin{array}{l}35.69 \\
32.47 \\
31.84\end{array}$ & 0.006 \\
\hline Fruits & $\begin{array}{ll}\text { - } & \text { Low } \\
\text { - } & \text { Medium } \\
\text { - } & \text { High }\end{array}$ & $\begin{array}{c}32.48 \\
4.48 \\
63.04\end{array}$ & $\begin{array}{c}36.16 \\
5.50 \\
58.33\end{array}$ & $\begin{array}{c}31.54 \\
4.02 \\
64.44\end{array}$ & $\begin{array}{c}24.84 \\
3.08 \\
72.08\end{array}$ & 0.013 \\
\hline
\end{tabular}




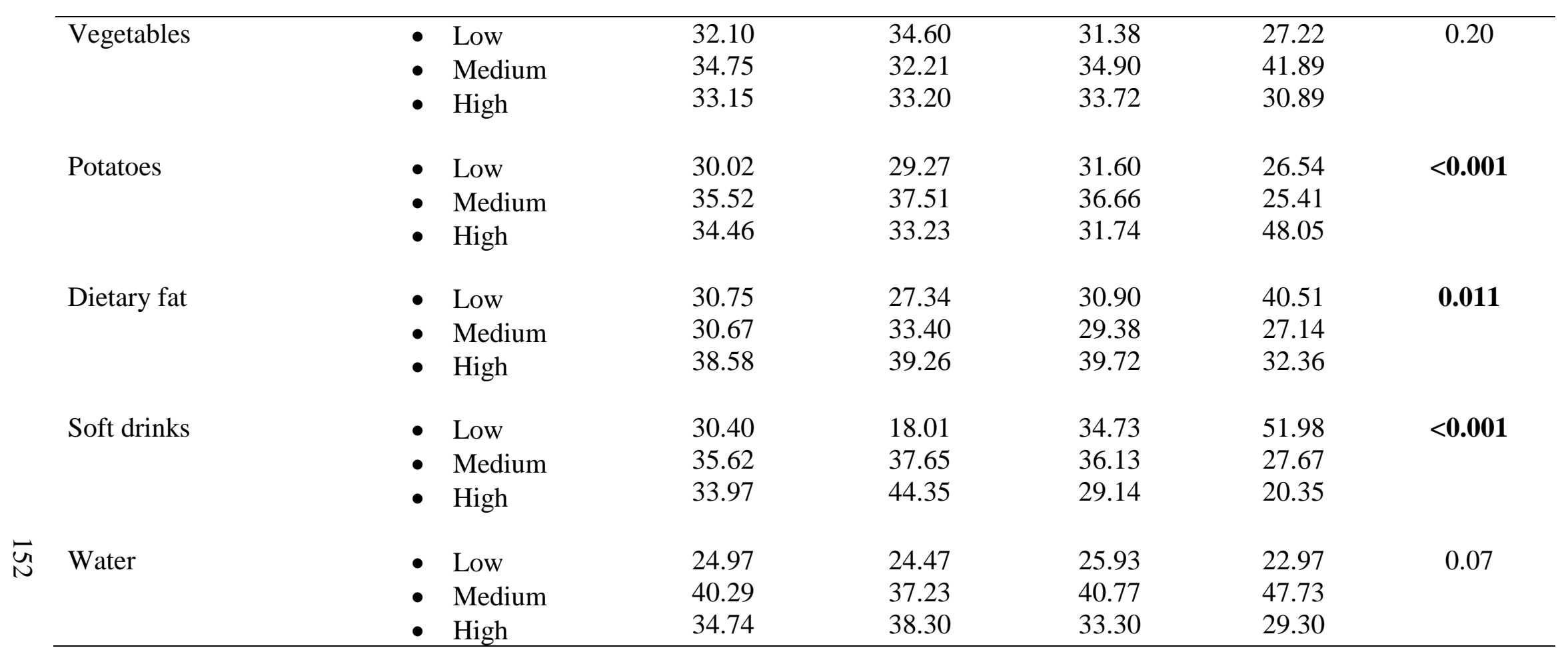

Red color text indicates statistical significance 
Table 4.6: Descriptive statistics (Cycle 3) of dietary factors (tertiles) by age group

\begin{tabular}{|c|c|c|c|c|c|c|}
\hline Dietary factors & $\begin{array}{c}\text { Tertiles } \\
\text { Times/week }\end{array}$ & $\begin{array}{c}\text { Overall } \\
\%\end{array}$ & $\begin{array}{c}\text { Young adult } \\
(=>18 \text { to }<40) \\
\%\end{array}$ & $\begin{array}{c}\text { Middle age } \\
(=>40 \text { to }<65) \\
\%\end{array}$ & $\begin{array}{c}\text { Older adult } \\
\begin{array}{c}(>=65) \\
\%\end{array}\end{array}$ & P-value \\
\hline Red meat & $\begin{array}{ll}\text { - } & \text { Low } \\
\text { - } & \text { Medium } \\
\text { - } & \text { High }\end{array}$ & $\begin{array}{l}35.55 \\
32.05 \\
32.40\end{array}$ & $\begin{array}{l}29.55 \\
32.15 \\
38.30\end{array}$ & $\begin{array}{l}38.36 \\
31.83 \\
29.82\end{array}$ & $\begin{array}{l}43.12 \\
32.54 \\
24.34\end{array}$ & $<0.001$ \\
\hline Fish & $\begin{array}{ll}\text { - } & \text { Low } \\
\text { - } & \text { Medium } \\
\text { - } & \text { High }\end{array}$ & $\begin{array}{l}30.97 \\
34.42 \\
34.60\end{array}$ & $\begin{array}{l}32.10 \\
42.28 \\
25.62\end{array}$ & $\begin{array}{l}30.56 \\
29.37 \\
40.07\end{array}$ & $\begin{array}{l}29.15 \\
29.29 \\
41.56\end{array}$ & $<0.001$ \\
\hline Eggs and eggs dishes & $\begin{array}{ll}\text { - } & \text { Low } \\
\text { - } & \text { Medium } \\
\text { - } & \text { High }\end{array}$ & $\begin{array}{l}21.41 \\
40.65 \\
37.93\end{array}$ & $\begin{array}{l}18.92 \\
39.07 \\
42.02\end{array}$ & $\begin{array}{l}22.29 \\
43.01 \\
34.69\end{array}$ & $\begin{array}{l}25.54 \\
37.09 \\
37.37\end{array}$ & 0.22 \\
\hline Beans and nuts & $\begin{array}{ll}\text { - } & \text { Low } \\
\text { - } & \text { Medium } \\
\text { - } & \text { High }\end{array}$ & $\begin{array}{l}33.31 \\
33.35 \\
33.34\end{array}$ & $\begin{array}{l}33.69 \\
33.91 \\
32.40\end{array}$ & $\begin{array}{l}33.04 \\
34.16 \\
32.80\end{array}$ & $\begin{array}{l}33.15 \\
28.99 \\
37.86\end{array}$ & 0.76 \\
\hline Milk and dairy products & $\begin{array}{ll}\text { - } & \text { Low } \\
\text { - } & \text { Medium } \\
\text { - } & \text { High }\end{array}$ & $\begin{array}{l}35.19 \\
33.16 \\
31.65\end{array}$ & $\begin{array}{l}32.76 \\
31.88 \\
35.37\end{array}$ & $\begin{array}{l}37.20 \\
34.40 \\
28.40\end{array}$ & $\begin{array}{l}35.25 \\
32.61 \\
32.14\end{array}$ & 0.24 \\
\hline Grains & $\begin{array}{ll}\text { - } & \text { Low } \\
\text { - } & \text { Medium } \\
\text { - } & \text { High }\end{array}$ & $\begin{array}{l}34.48 \\
35.48 \\
30.03\end{array}$ & $\begin{array}{l}34.22 \\
39.20 \\
26.58\end{array}$ & $\begin{array}{l}35.82 \\
33.65 \\
30.52\end{array}$ & $\begin{array}{l}30.63 \\
31.13 \\
38.24\end{array}$ & 0.013 \\
\hline Fruits & $\begin{array}{ll}\text { - } & \text { Low } \\
\text { - } & \text { Medium } \\
\text { - } & \text { High }\end{array}$ & $\begin{array}{l}34.57 \\
35.51 \\
29.93\end{array}$ & $\begin{array}{l}37.93 \\
36.89 \\
25.17\end{array}$ & $\begin{array}{l}33.74 \\
33.37 \\
32.89\end{array}$ & $\begin{array}{l}27.74 \\
38.89 \\
33.37\end{array}$ & 0.048 \\
\hline
\end{tabular}




\begin{tabular}{|c|c|c|c|c|c|c|}
\hline Vegetables & $\begin{array}{ll}\text { - } & \text { Low } \\
\text { - } & \text { Medium } \\
\text { - } & \text { High }\end{array}$ & $\begin{array}{l}33.81 \\
33.77 \\
32.42\end{array}$ & $\begin{array}{l}35.37 \\
34.54 \\
30.09\end{array}$ & $\begin{array}{l}33.04 \\
32.73 \\
34.23\end{array}$ & $\begin{array}{l}31.96 \\
35.14 \\
32.90\end{array}$ & 0.80 \\
\hline Soft drinks & $\begin{array}{ll}\text { - } & \text { Low } \\
\text { - } & \text { Medium } \\
\text { - } & \text { High }\end{array}$ & $\begin{array}{l}30.87 \\
31.98 \\
37.15\end{array}$ & $\begin{array}{l}15.82 \\
37.49 \\
46.69\end{array}$ & $\begin{array}{l}38.68 \\
28.83 \\
32.49\end{array}$ & $\begin{array}{l}47.10 \\
27.02 \\
25.87\end{array}$ & $<0.001$ \\
\hline
\end{tabular}

Bold text indicates statistical significance 
Tables 4.7, 4.8, and 4.9 show the descriptive statistics for the Canada Food Guide by age group for Cycles 1, 2, and 3, respectively. Statistically significant (p-value <0.05) relationships were observed only between milk and milk alternatives and age group (Cycles 1, 2, 3). The proportion of participants who were within the "not meeting" Canada food requirement of milk and milk alternatives increased as the age group increased (Cycles 1, 2, 3). However, in Cycles 1, 2, and 3 opposite patterns was observed within the participants of "meeting" Canada food requirement where the proportion of participants were decreased as the age group increased. 
Table 4.7: Descriptive statistics (Cycle 1) of Canada Food Guide by age group

\begin{tabular}{|c|c|c|c|c|c|c|}
\hline \multicolumn{2}{|c|}{ Variables for Canada Food Guide } & $\begin{array}{c}\text { Overall } \\
\%\end{array}$ & $\begin{array}{c}\text { Young adult } \\
(=>18 \text { to }<40) \\
\%\end{array}$ & $\begin{array}{c}\text { Middle age } \\
(=>40 \text { to }<65) \\
\%\end{array}$ & $\begin{array}{c}\text { Older adult } \\
\begin{array}{c}(>=65) \\
\%\end{array}\end{array}$ & P-value \\
\hline $\begin{array}{l}\text { Vegetables and } \\
\text { fruits }\end{array}$ & $\begin{array}{ll}\text { - } & \text { 1- Not meeting } \\
\text { - } & \text { 2- Meeting }\end{array}$ & $\begin{array}{l}89.39 \\
10.61\end{array}$ & $\begin{array}{l}90.86 \\
9.14\end{array}$ & $\begin{array}{l}87.94 \\
12.06\end{array}$ & $\begin{array}{l}90.15 \\
9.85\end{array}$ & 0.07 \\
\hline $\begin{array}{l}\text { Milk and Milk } \\
\text { alternatives }\end{array}$ & $\begin{array}{l}\text { - } 1 \text { - Not meeting } \\
\text { - } 2 \text { - Meeting }\end{array}$ & $\begin{array}{l}74.05 \\
25.95\end{array}$ & $\begin{array}{l}62.94 \\
37.06\end{array}$ & $\begin{array}{l}79.71 \\
20.29\end{array}$ & $\begin{array}{l}88.15 \\
11.85\end{array}$ & $<0.001$ \\
\hline $\begin{array}{l}\text { Meat and meat } \\
\text { alternatives }\end{array}$ & $\begin{array}{l}\text { - } 1 \text { - Not meeting } \\
\text { - 2-Meeting }\end{array}$ & $\begin{array}{l}85.69 \\
14.31\end{array}$ & $\begin{array}{l}84.39 \\
15.61\end{array}$ & $\begin{array}{l}86.95 \\
13.05\end{array}$ & $\begin{array}{l}85.14 \\
14.86\end{array}$ & 0.18 \\
\hline
\end{tabular}

Bold text indicates statistical significance

Table 4.8: Descriptive statistics (Cycle 2) of Canada Food Guide by age group $\overrightarrow{\text { ă }}$

\begin{tabular}{|c|c|c|c|c|c|c|}
\hline \multicolumn{2}{|c|}{ Variables for Canada Food Guide } & \multirow{2}{*}{$\begin{array}{c}\text { Overall } \\
\%\end{array}$} & \multirow{2}{*}{$\begin{array}{c}\begin{array}{c}\text { Young adult } \\
(=>\mathbf{1 8} \text { to }<40) \\
\%\end{array} \\
91.36 \\
8.64\end{array}$} & \multirow{2}{*}{$\begin{array}{c}\begin{array}{c}\text { Middle age } \\
(=>40 \text { to }<65) \\
\text { \% }\end{array} \\
91.27 \\
8.73\end{array}$} & \multirow{2}{*}{$\begin{array}{c}\begin{array}{c}\text { Older adult } \\
(>=65) \\
\%\end{array} \\
88.99 \\
11.01\end{array}$} & \multirow{2}{*}{$\begin{array}{c}\text { P-value } \\
0.48\end{array}$} \\
\hline $\begin{array}{l}\text { Vegetables and } \\
\text { fruits }\end{array}$ & $\begin{array}{l}\text { - } 1 \text { - Not meeting } \\
\text { - } 2 \text { - Meeting }\end{array}$ & & & & & \\
\hline $\begin{array}{l}\text { Milk and Milk } \\
\text { alternatives }\end{array}$ & $\begin{array}{l}\text { - } 1 \text { - Not meeting } \\
\text { - } 2 \text { - Meeting }\end{array}$ & $\begin{array}{l}77.78 \\
22.23\end{array}$ & $\begin{array}{l}67.79 \\
32.21\end{array}$ & $\begin{array}{l}82.43 \\
17.57\end{array}$ & $\begin{array}{c}90.88 \\
9.12\end{array}$ & $<0.001$ \\
\hline $\begin{array}{l}\text { Meat and meat } \\
\text { alternatives }\end{array}$ & $\begin{array}{l}\text { - } 1 \text { - Not meeting } \\
\text { - } 2 \text { - Meeting }\end{array}$ & $\begin{array}{l}82.00 \\
18.00\end{array}$ & $\begin{array}{l}82.07 \\
17.93\end{array}$ & $\begin{array}{l}81.62 \\
18.38\end{array}$ & $\begin{array}{l}83.20 \\
16.80\end{array}$ & 0.86 \\
\hline
\end{tabular}

Bold text indicates statistical significance 
Table 4.9: Descriptive statistics (Cycle 3) of Canada Food Guide by age group

\begin{tabular}{|c|c|c|c|c|c|c|}
\hline \multicolumn{2}{|c|}{ Variables for Canada Food Guide } & \multirow{2}{*}{$\begin{array}{c}\begin{array}{c}\text { Overall } \\
\%\end{array} \\
96.38 \\
3.62\end{array}$} & \multirow{2}{*}{$\begin{array}{c}\begin{array}{c}\text { Young adult } \\
(=>\mathbf{1 8} \text { to }<\mathbf{4 0}) \\
\%\end{array} \\
97.13 \\
2.87\end{array}$} & \multirow{2}{*}{$\begin{array}{c}\begin{array}{c}\text { Middle age } \\
(=>40 \text { to }<\mathbf{6 5}) \\
\text { \% }\end{array} \\
95.96 \\
4.04\end{array}$} & \multirow{2}{*}{$\begin{array}{c}\begin{array}{c}\text { Older adult } \\
(>=65) \\
\text { \% }\end{array} \\
95.73 \\
4.23\end{array}$} & \multirow{2}{*}{$\begin{array}{c}\text { P-value } \\
0.43\end{array}$} \\
\hline $\begin{array}{l}\text { Vegetables and } \\
\text { fruits }\end{array}$ & $\begin{array}{ll}\text { - } & \text { 1- Not meeting } \\
\text { - } & \text { 2-Meeting }\end{array}$ & & & & & \\
\hline $\begin{array}{l}\text { Milk and Milk } \\
\text { alternatives }\end{array}$ & $\begin{array}{l}\text { - } 1 \text { - Not meeting } \\
\text { - } 2 \text { - Meeting }\end{array}$ & $\begin{array}{l}67.84 \\
32.16\end{array}$ & $\begin{array}{l}54.58 \\
45.42\end{array}$ & $\begin{array}{l}74.08 \\
25.92\end{array}$ & $\begin{array}{l}84.39 \\
15.61\end{array}$ & $<0.001$ \\
\hline $\begin{array}{l}\text { Meat and meat } \\
\text { alternatives }\end{array}$ & $\begin{array}{l}\text { - } 1 \text { - Not meeting } \\
\text { - } 2 \text { - Meeting }\end{array}$ & $\begin{array}{l}36.42 \\
63.58\end{array}$ & $\begin{array}{l}37.67 \\
62.33\end{array}$ & $\begin{array}{l}35.55 \\
64.45\end{array}$ & $\begin{array}{l}35.82 \\
64.18\end{array}$ & 0.75 \\
\hline
\end{tabular}

Bold text indicates statistical significance

Table 4.10: Scoring of Mediterranean Diet

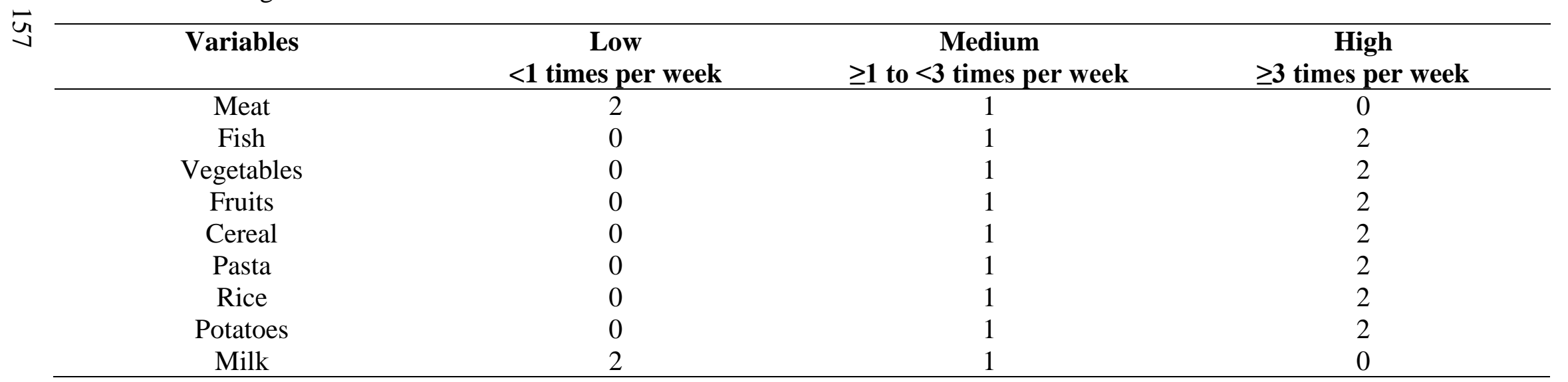


Table 4.11 shows the descriptive statistics of mean, median, mode, $75 \%$ percentile, and 25\% percentile of the modified Mediterranean Diet Score. Overall the score was consistent throughout the Cycles and age group. 
Table 4.11: Modified Mediterranean Diet Score for all Cycles by age group

\begin{tabular}{|c|c|c|c|c|c|c|c|c|c|}
\hline \multirow{2}{*}{$\begin{array}{c}\text { Modified } \\
\text { Mediterranean } \\
\text { Diet Score } \\
\text { (total possible } \\
\text { score=27) }\end{array}$} & \multicolumn{3}{|c|}{ Cycle 1} & \multicolumn{3}{|c|}{ Cycle 2} & \multicolumn{3}{|c|}{ Cycle 3} \\
\hline & $\begin{array}{c}\text { Young } \\
\text { adult } \\
(=>18 \text { to } \\
<40)\end{array}$ & $\begin{array}{c}\text { Middle } \\
\text { age } \\
(=>40 \text { to } \\
<65)\end{array}$ & $\begin{array}{c}\text { Older } \\
\text { adult } \\
(>=65)\end{array}$ & $\begin{array}{c}\text { Young } \\
\text { adult } \\
(=>18 \text { to } \\
<40)\end{array}$ & $\begin{array}{c}\text { Middle } \\
\text { age } \\
(=>40 \text { to } \\
<65)\end{array}$ & $\begin{array}{c}\text { Older } \\
\text { adult } \\
(>=65)\end{array}$ & $\begin{array}{c}\text { Young } \\
\text { adult } \\
(=>18 \text { to } \\
<40)\end{array}$ & $\begin{array}{c}\begin{array}{c}\text { Middle } \\
\text { age }\end{array} \\
(=>40 \\
\text { to }<65)\end{array}$ & $\begin{array}{c}\text { Older } \\
\text { adult } \\
(>=65)\end{array}$ \\
\hline Mean & & 10.09 & & \multicolumn{3}{|c|}{10.46} & \multicolumn{3}{|c|}{9.76} \\
\hline$(95 \% \mathrm{CI})$ & \multicolumn{3}{|c|}{$(9.99-10.19)$} & \multicolumn{3}{|c|}{$(10.32-10.60)$} & \multicolumn{3}{|c|}{$(9.60-9.92)$} \\
\hline Median & 10 & 10 & 10 & 11 & 11 & 10 & 10 & 10 & 10 \\
\hline Mode & 10 & 10 & 10 & 11 & 11 & 10 & 10 & 10 & 10 \\
\hline $75 \%$ percentile & 12 & 11 & 11 & 12 & 12 & 11 & 11 & 11 & 11 \\
\hline
\end{tabular}


Tables $4.12,4.13$, and 4.14 show the descriptive statistics for the biomarkers by age group for Cycle 1, 2, and 3, respectively. Statistically significant (p-value <0.05) relationships were observed between biomarkers and the age group including red blood cell folate (Cycles 1, 2, 3), Vitamin D (Cycles 1, 2, 3), total protein (Cycles 1, 2, 3), potassium (Cycles 1, 2, 3), serum creatinine (Cycles 1, 2, 3), calcium (Cycles 1, 2, 3), urine creatinine (Cycles 1, 2, 3), c-reactive protein (Cycles 1, 2), Vitamin B12 (Cycles 1, 3), sodium (Cycles 1, 2), chloride (Cycles 1, 3), high density lipoprotein (Cycle 3), and total cholesterol (Cycle 3).

- The mean values of red blood cell folate were increased as the age group increased (Cycles 1, 2, 3).

- The mean values of Vitamin D were increased as the age group increased (Cycles 1,3) while the proportion of participants showed a U-shaped pattern in Cycle 2.

- The mean values of total protein were gradually decreased as the age group increased (Cycles 1, 2, 3).

- The mean values of potassium were gradually increased as the age group increased (Cycles 1, 2, 3).

- The mean values of C-reactive protein were gradually increased as the age group increased (Cycles 1, 2).

- The mean values of Vitamin B12 were gradually increased as the age group increased (Cycles 1, 3).

- The mean values of high density lipoprotein (HDL) were gradually increased as the age group increased (Cycles 1, 3).

- The mean values of total cholesterol showed an inverse U-shaped pattern as the age group increased (Cycle 3). 
Table 4.12: Descriptive statistics (Cycle 1) of biomarkers by age groups

\begin{tabular}{|c|c|c|c|c|c|c|}
\hline Biomarkers & Normal range & $\begin{array}{c}\text { Overall } \\
\text { (Mean, SE) }\end{array}$ & $\begin{array}{c}\text { Young adult } \\
(=>18 \text { to }<40) \\
(\text { Mean, } S E) \\
\end{array}$ & $\begin{array}{c}\text { Middle age } \\
(=>40 \text { to }<65) \\
(\text { Mean, SE) }\end{array}$ & $\begin{array}{c}\text { Older adult } \\
(>=65) \\
(\text { Mean, SE) }\end{array}$ & P-value \\
\hline $\begin{array}{l}\text { Red blood cell folate } \\
\text { (nmol/L) }\end{array}$ & $317-1422^{\mathrm{a}}$ & $1355.80 \pm 43.23$ & $1249.90 \pm 36.29$ & $1403.53 \pm 50.72$ & $1516.00 \pm 74.72$ & $<0.001$ \\
\hline Vitamin D (nmol/L) & $75-150^{b}$ & $67.32 \pm 1.20$ & $65.58 \pm 2.05$ & $67.11 \pm 1.23$ & $73.61 \pm 1.57$ & $<0.001$ \\
\hline Total protein $(\mathrm{g} / \mathrm{L})$ & $60-80^{b}$ & $73.50 \pm 0.19$ & $74.64 \pm 0.25$ & $72.91 \pm 0.21$ & $72.15 \pm 0.27$ & $<0.001$ \\
\hline Chloride (mmol/L) & $98-108^{b}$ & $104.38 \pm 0.12$ & $104.36 \pm 0.11$ & $104.56 \pm 0.15$ & $103.74 \pm 0.19$ & $<0.001$ \\
\hline Potassium (mmol/L) & $\begin{array}{c}\text { Men: } 3.5-4.5^{\mathrm{b}} \\
\text { Women: } 3.4-4.4^{\mathrm{b}}\end{array}$ & $4.31 \pm 0.02$ & $4.27 \pm 0.02$ & $4.32 \pm 0.02$ & $4.37 \pm 0.02$ & $<0.001$ \\
\hline Sodium (mmol/L) & $135-145^{\mathrm{b}}$ & $139.95 \pm 0.14$ & $139.89 \pm 0.15$ & $140.04 \pm 0.15$ & $139.75 \pm 0.13$ & 0.015 \\
\hline $\begin{array}{l}\text { Calcium (total) } \\
(\mathrm{mmol} / \mathrm{L})\end{array}$ & $2.10-2.60^{\mathrm{b}}$ & $2.41 \pm 0.01$ & $2.41 \pm 0.01$ & $2.40 \pm 0.01$ & $2.41 \pm 0.01$ & $<0.001$ \\
\hline $\begin{array}{l}\text { C-reactive protein } \\
(\mathrm{mg} / \mathrm{L})\end{array}$ & $\begin{array}{l}\text { Intermediate } \\
\text { risk:1.0-3.0 }\end{array}$ & $2.33 \pm 0.07$ & $2.04 \pm 0.13$ & $2.45 \pm 0.08$ & $2.73 \pm 0.13$ & $<0.001$ \\
\hline Total protein $(\mathrm{g} / \mathrm{L})$ & $60-80^{\mathrm{b}}$ & $73.50 \pm 0.19$ & $74.64 \pm 0.25$ & $72.91 \pm 0.21$ & $72.15 \pm 0.27$ & $<0.001$ \\
\hline $\begin{array}{l}\text { High density } \\
\text { lipoprotein (HDL) } \\
(\mathrm{mmol} / \mathrm{L})\end{array}$ & $\begin{array}{c}\text { Men: }>0.99^{\mathrm{b}} \\
\text { Women: }>1.19^{\mathrm{b}}\end{array}$ & $1.33 \pm 0.02$ & $1.32 \pm 0.02$ & $1.33 \pm 0.03$ & $1.36 \pm 0.03$ & 0.12 \\
\hline $\begin{array}{l}\text { Total cholesterol } \\
(\mathrm{mmol} / \mathrm{L})\end{array}$ & $2.0-5.19^{b}$ & $7.26 \pm 0.64$ & $7.81 \pm 0.86$ & $6.91 \pm 0.72$ & $6.81 \pm 1.02$ & 0.16 \\
\hline Vitamin B12 (pmol/L) & $153-655^{b}$ & $334.08 \pm 3.99$ & $322.10 \pm 4.66$ & $339.65 \pm 5.77$ & $351.60 \pm 7.98$ & $<0.001$ \\
\hline
\end{tabular}

Bold text indicates statistical significance

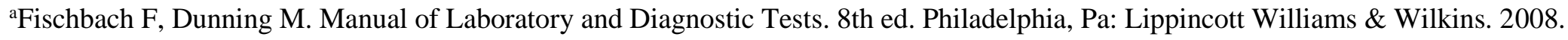

${ }^{\mathrm{b}}$ LifeLabs (Burnaby reference laboratory). Reference Ranges - Healthcare Providers. 2017. 
Table 4.13: Descriptive statistics (Cycle 2) of biomarkers by age groups

\begin{tabular}{|c|c|c|c|c|c|c|}
\hline Biomarkers & Normal range & $\begin{array}{c}\text { Overall } \\
\text { (Mean, SE) }\end{array}$ & $\begin{array}{c}\text { Young adult } \\
(=>18 \text { to }<40) \\
(\text { Mean, } S E) \\
\end{array}$ & $\begin{array}{c}\text { Middle age } \\
(=>40 \text { to }<65) \\
(\text { Mean, } \mathrm{SE}) \\
\end{array}$ & $\begin{array}{c}\text { Older adult } \\
(>=65) \\
(\text { Mean, SE) }\end{array}$ & P-value \\
\hline $\begin{array}{l}\text { Red blood cell } \\
\text { folate (nmol/L) }\end{array}$ & $317-1422^{\mathrm{a}}$ & $1270.07 \pm 32.39$ & $1179.49 \pm 36.10$ & $1297.25 \pm 33.98$ & $1451.05 \pm 44.98$ & $<0.001$ \\
\hline $\begin{array}{l}\text { Vitamin D } \\
(\mathrm{nmol} / \mathrm{L})\end{array}$ & $75-150^{b}$ & $69.48 \pm 2.28$ & $68.96 \pm 3.32$ & $67.41 \pm 2.34$ & $78.59 \pm 3.97$ & 0.020 \\
\hline Total protein $(\mathrm{g} / \mathrm{L})$ & $60-80^{\mathrm{b}}$ & $72.48 \pm 0.20$ & $73.48 \pm 0.29$ & $71.94 \pm 0.23$ & $71.42 \pm 0.27$ & $<0.001$ \\
\hline Chloride (mmol/L) & $98-108^{b}$ & $103.74 \pm 0.09$ & $103.75 \pm 0.09$ & $103.78 \pm 0.12$ & $103.54 \pm 0.13$ & 0.11 \\
\hline $\begin{array}{l}\text { Potassium } \\
(\mathrm{mmol} / \mathrm{L})\end{array}$ & $\begin{array}{c}\text { Men: } 3.5-4.5^{\mathrm{b}} \\
\text { Women: } 3.4-4^{\mathrm{b}}\end{array}$ & $4.47 \pm 0.01$ & $4.44 \pm 0.01$ & $4.48 \pm 0.01$ & $4.53 \pm 0.02$ & $<0.001$ \\
\hline Sodium $(\mathrm{mmol} / \mathrm{L})$ & $135-145^{\mathrm{b}}$ & $140.00 \pm 0.20$ & $140.03 \pm 0.20$ & $139.91 \pm 0.22$ & $140.25 \pm 0.21$ & 0.003 \\
\hline $\begin{array}{l}\text { Calcium (total) } \\
(\mathrm{mmol} / \mathrm{L})\end{array}$ & $2.10-2.60^{\mathrm{b}}$ & $2.42 \pm 0.01$ & $2.42 \pm 0.01$ & $2.41 \pm 0.01$ & $2.42 \pm 0.01$ & $<0.001$ \\
\hline $\begin{array}{l}\text { C-reactive protein } \\
(\mathrm{mg} / \mathrm{L})\end{array}$ & $\begin{array}{l}\text { Intermediate } \\
\text { risk: } 1.0-3.0^{\mathrm{b}}\end{array}$ & $2.42 \pm 0.08$ & $2.11 \pm 0.13$ & $2.56 \pm 0.11$ & $2.82 \pm 0.14$ & $<0.001$ \\
\hline Total protein $(\mathrm{g} / \mathrm{L})$ & $60-80$ & $72.48 \pm 0.20$ & $73.48 \pm 0.29$ & $71.94 \pm 0.23$ & $71.42 \pm 0.27$ & $<0.001$ \\
\hline $\begin{array}{l}\text { High density } \\
\text { lipoprotein (HDL) } \\
(\mathrm{mmol} / \mathrm{L})\end{array}$ & $\begin{array}{c}\text { Men: }>0.99^{b} \\
\text { Women: }>1.19^{b}\end{array}$ & $1.41 \pm 0.02$ & $1.40 \pm 0.03$ & $1.41 \pm 0.02$ & $1.41 \pm 0.02$ & 0.92 \\
\hline $\begin{array}{l}\text { Total cholesterol } \\
(\mathrm{mmol} / \mathrm{L})\end{array}$ & $2.0-5.19^{b}$ & $5.78 \pm 0.25$ & $5.38 \pm 0.29$ & $6.11 \pm 0.37$ & $5.76 \pm 0.27$ & 0.07 \\
\hline $\begin{array}{l}\text { Vitamin B12 } \\
(\mathrm{pmol} / \mathrm{L})\end{array}$ & $153-655^{b}$ & $347.10 \pm 6.45$ & $341.08 \pm 8.23$ & $353.44 \pm 9.09$ & $341.72 \pm 11.41$ & 0.05 \\
\hline
\end{tabular}

Bold text indicates statistical significance

aFischbach F, Dunning M. Manual of Laboratory and Diagnostic Tests. 8th ed. Philadelphia, Pa: Lippincott Williams \& Wilkins. 2008.

${ }^{\mathrm{b}}$ LifeLabs (Burnaby reference laboratory). Reference Ranges - Healthcare Providers. 2017. 
Table 4.14: Descriptive statistics (Cycle 3) of biomarkers by age groups

\begin{tabular}{|c|c|c|c|c|c|c|}
\hline Biomarkers & Normal range & $\begin{array}{c}\text { Overall } \\
(\text { mean, } S E)\end{array}$ & $\begin{array}{c}\text { Young adult } \\
(=>18 \text { to }<40) \\
(\text { mean, } \mathrm{SE}) \\
\end{array}$ & $\begin{array}{c}\text { Middle age } \\
(=>40 \text { to }<65) \\
(\text { mean, SE) }\end{array}$ & $\begin{array}{c}\text { Older adult } \\
(>=65) \\
(\text { mean, SE) }\end{array}$ & P-value \\
\hline $\begin{array}{l}\text { Red blood cell folate } \\
\text { (nmol/L) }\end{array}$ & $317-1422^{\mathrm{a}}$ & $1269.26 \pm 44.71$ & $1206.72 \pm 47.87$ & $1288.06 \pm 43.70$ & $1380.51 \pm 55.39$ & $<0.001$ \\
\hline Vitamin D (nmol/L) & $75-150^{b}$ & $61.20 \pm 2.70$ & $58.16 \pm 3.89$ & $60.64 \pm 2.43$ & $71.62 \pm 2.17$ & $<0.001$ \\
\hline Total protein $(\mathrm{g} / \mathrm{L})$ & $60-80^{b}$ & $71.63 \pm 0.32$ & $73.13 \pm 0.36$ & $70.78 \pm 0.32$ & $70.32 \pm 0.44$ & $<0.001$ \\
\hline Chloride (mmol/L) & $98-108^{b}$ & $104.11 \pm 0.15$ & $104.09 \pm 0.17$ & $104.24 \pm 0.18$ & $103.71 \pm 0.15$ & $<0.001$ \\
\hline Potassium (mmol/L) & $\begin{array}{c}\text { Men: } 3.5-4.5^{\mathrm{b}} \\
\text { Women: } 3.4-4.4^{\mathrm{b}}\end{array}$ & $4.37 \pm 0.02$ & $4.33 \pm 0.02$ & $4.37 \pm 0.02$ & $4.46 \pm 0.04$ & $<0.001$ \\
\hline Sodium (mmol/L) & $135-145^{\mathrm{b}}$ & $141.44 \pm 0.19$ & $141.39 \pm 0.22$ & $141.48 \pm 0.22$ & $141.42 \pm 0.18$ & 0.56 \\
\hline $\begin{array}{l}\text { Calcium (total) } \\
(\mathrm{mmol} / \mathrm{L})\end{array}$ & $2.10-2.60^{\mathrm{b}}$ & $2.41 \pm 0.01$ & $2.41 \pm 0.01$ & $2.40 \pm 0.01$ & $2.41 \pm 0.01$ & 0.005 \\
\hline $\begin{array}{l}\text { C-reactive protein } \\
(\mathrm{mg} / \mathrm{L})\end{array}$ & $\begin{array}{l}\text { Intermediate } \\
\text { risk: } 1.0-3.0^{\mathrm{b}}\end{array}$ & $2.55 \pm 0.14$ & $2.61 \pm 0.26$ & $2.49 \pm 0.13$ & $2.57 \pm 0.16$ & 0.56 \\
\hline Total protein $(\mathrm{g} / \mathrm{L})$ & $60-80^{\mathrm{b}}$ & $71.63 \pm 0.32$ & $73.13 \pm 0.36$ & $70.78 \pm 0.32$ & $70.32 \pm 0.44$ & $<0.001$ \\
\hline $\begin{array}{l}\text { High density } \\
\text { lipoprotein (HDL) } \\
(\mathrm{mmol} / \mathrm{L})\end{array}$ & $\begin{array}{c}\text { Men: }>0.99^{\mathrm{b}} \\
\text { Women: }>1.19^{\mathrm{b}}\end{array}$ & $1.38 \pm 0.02$ & $1.35 \pm 0.03$ & $1.39 \pm 0.02$ & $1.42 \pm 0.03$ & 0.003 \\
\hline $\begin{array}{l}\text { Total cholesterol } \\
(\mathrm{mmol} / \mathrm{L})\end{array}$ & $2.0-5.19^{b}$ & $4.82 \pm 0.05$ & $4.57 \pm 0.07$ & $5.03 \pm 0.06$ & $4.41 \pm 0.08$ & $<0.001$ \\
\hline Vitamin B12 (pmol/L) & $153-655^{b}$ & $322.31 \pm 8.28$ & $313.61 \pm 18.61$ & $318.89 \pm 6.93$ & $358.62 \pm 13.77$ & $<0.001$ \\
\hline
\end{tabular}

Bold text indicates statistical significance

${ }^{a}$ Fischbach F, Dunning M. Manual of Laboratory and Diagnostic Tests. 8th ed. Philadelphia, Pa: Lippincott Williams \& Wilkins. 2008.

${ }^{\mathrm{b}}$ LifeLabs (Burnaby reference laboratory). Reference Ranges - Healthcare Providers. 2017. 
Table 4.15: Distribution of the dietary factors by region (Cycle 1)

\begin{tabular}{|c|c|c|c|c|c|c|}
\hline Dietary variables & $\begin{array}{c}\text { Alberta } \\
\%\end{array}$ & $\begin{array}{c}\text { British } \\
\text { Columbia } \\
\%\end{array}$ & $\begin{array}{c}\text { Ontario } \\
\%\end{array}$ & $\begin{array}{c}\text { Quebec } \\
\%\end{array}$ & $\begin{array}{c}\text { New Brunswick } \\
\%\end{array}$ & p-value \\
\hline Red meat & & & & & & 0.1 \\
\hline Low & 27.7 & 36.0 & 39.2 & 25.8 & 29.5 & \\
\hline Medium & 29.9 & 30.1 & 29.7 & 34.0 & 40.0 & \\
\hline High & 42.4 & 33.9 & 31.2 & 40.1 & 30.6 & \\
\hline Fish & & & & & & 0.002 \\
\hline Low & 35.4 & 28.5 & 38.6 & 27.8 & 31.5 & \\
\hline Medium & 38.1 & 31.4 & 31.1 & 27.7 & 25.3 & \\
\hline High & 26.5 & 40.1 & 30.3 & 44.5 & 43.2 & \\
\hline Eggs & & & & & & 0.4 \\
\hline Low & 24.8 & 24.3 & 27.1 & 19.8 & 27.6 & \\
\hline Medium & 29.8 & 21.5 & 26.4 & 28.2 & 27.1 & \\
\hline High & 45.3 & 54.2 & 46.4 & 52.0 & 45.3 & \\
\hline Beans & & & & & & $<0.001$ \\
\hline Low & 31.5 & 20.2 & 32.9 & 32.0 & 41.9 & \\
\hline Medium & 35.4 & 34.2 & 36.7 & 37.7 & 36.0 & \\
\hline High & 33.1 & 45.6 & 30.4 & 30.3 & 22.1 & \\
\hline Milk & & & & & & 0.7 \\
\hline Low & 29.8 & 39.6 & 35.3 & 33.0 & 28.2 & \\
\hline Medium & 37.0 & 32.7 & 32.0 & 32.7 & 31.0 & \\
\hline High & 33.2 & 27.6 & 32.7 & 34.3 & 40.7 & \\
\hline Grains & & & & & & 0.8 \\
\hline Low & 32.2 & 37.6 & 32.9 & 32.3 & 38.3 & \\
\hline Medium & 36.5 & 31.5 & 32.4 & 33.2 & 28.0 & \\
\hline High & 31.3 & 30.8 & 34.7 & 34.5 & 33.7 & \\
\hline
\end{tabular}




\begin{tabular}{|c|c|c|c|c|c|c|}
\hline Fruits & & & & & & 0.1 \\
\hline Low & 31.5 & 31.1 & 29.5 & 27.7 & 35.3 & \\
\hline Medium & 37.7 & 41.2 & 41.4 & 34.8 & 33.8 & \\
\hline High & 30.8 & 27.7 & 29.1 & 37.6 & 30.9 & \\
\hline Vegetables & & & & & & 0.5 \\
\hline Low & 32.9 & 31.0 & 36.6 & 32.5 & 44.2 & \\
\hline Medium & 34.5 & 34.5 & 33.8 & 29.4 & 31.1 & \\
\hline High & 32.6 & 34.5 & 29.6 & 38.2 & 24.7 & \\
\hline Potatoes & & & & & & 0.7 \\
\hline Low & 32.6 & 45.8 & 37.1 & 29.7 & 28.2 & \\
\hline Medium & 34.7 & 27.2 & 32.1 & 33.9 & 31.0 & \\
\hline High & 32.7 & 27.0 & 30.7 & 36.4 & 40.7 & \\
\hline Dietary fat & & & & & & 0.008 \\
\hline Low & 31.0 & 34.0 & 36.1 & 27.6 & 38.1 & \\
\hline Medium & 37.7 & 31.4 & 33.6 & 33.7 & 29.4 & \\
\hline High & 31.3 & 34.6 & 30.3 & 38.7 & 32.5 & \\
\hline Soft drinks & & & & & & 0.1 \\
\hline Low & 23.7 & 37.0 & 28.7 & 33.0 & 24.9 & \\
\hline Medium & 40.5 & 38.8 & 36.3 & 30.9 & 36.8 & \\
\hline High & 35.8 & 24.1 & 35.0 & 36.1 & 38.2 & \\
\hline Water & & & & & & $<0.001$ \\
\hline Low & 23.9 & 25.2 & 35.1 & 29.6 & 33.4 & \\
\hline Medium & 27.6 & 27.9 & 30.9 & 35.5 & 32.6 & \\
\hline High & 48.5 & 46.9 & 34.0 & 35.0 & 33.9 & \\
\hline
\end{tabular}


Table 4.16: Distribution of the dietary factors by region (Cycle 2)

\begin{tabular}{|c|c|c|c|c|c|c|c|c|}
\hline Dietary variables & $\begin{array}{c}\text { Alberta } \\
\%\end{array}$ & $\begin{array}{c}\text { British } \\
\text { Columbia } \\
\%\end{array}$ & $\begin{array}{c}\text { Ontario } \\
\%\end{array}$ & $\begin{array}{c}\text { Quebec } \\
\%\end{array}$ & $\begin{array}{c}\text { Manitoba } \\
\%\end{array}$ & $\begin{array}{c}\text { Newfoundland } \\
\text { and Labrador } \\
\%\end{array}$ & $\begin{array}{c}\text { Nova } \\
\text { Scotia } \\
\%\end{array}$ & P-value \\
\hline Red meat & & & & & & & & 0.01 \\
\hline Low & 33.9 & 27.4 & 37.2 & 26.1 & 21.1 & 46.2 & 36.3 & \\
\hline Medium & 25.4 & 34.9 & 30.3 & 34.1 & 40.5 & 23.2 & 28.6 & \\
\hline High & 40.8 & 37.6 & 32.6 & 39.7 & 38.4 & 30.6 & 35.1 & \\
\hline Fish & & & & & & & & 0.3 \\
\hline Low & 36.0 & 26.6 & 30.2 & 29.7 & 41.7 & 29.6 & 35.7 & \\
\hline Medium & 29.7 & 32.7 & 30.8 & 37.5 & 37.7 & 41.5 & 35.2 & \\
\hline High & 34.3 & 40.8 & 39.0 & 32.8 & 20.7 & 29.0 & 29.0 & \\
\hline Eggs & & & & & & & & 0.02 \\
\hline Low & 18.2 & 20.6 & 21.4 & 21.2 & 19.8 & 25.6 & 23.8 & \\
\hline Medium & 23.6 & 15.5 & 24.8 & 30.0 & 26.4 & 17.8 & 28.5 & \\
\hline High & 58.1 & 63.9 & 53.8 & 48.8 & 53.8 & 56.7 & 47.7 & \\
\hline Beans & & & & & & & & $<0.001$ \\
\hline Low & 28.0 & 31.7 & 26.5 & 31.2 & 41.4 & 43.0 & 49.2 & \\
\hline Medium & 38.6 & 25.9 & 32.5 & 34.4 & 26.2 & 40.4 & 32.0 & \\
\hline High & 33.5 & 42.4 & 41.1 & 34.4 & 32.5 & 16.6 & 18.7 & \\
\hline Milk & & & & & & & & 0.04 \\
\hline Low & 40.5 & 45.2 & 34.6 & 39.3 & 30.0 & 29.3 & 28.3 & \\
\hline Medium & 26.4 & 31.5 & 34.4 & 31.7 & 33.4 & 31.9 & 32.0 & \\
\hline High & 33.1 & 23.2 & 31.1 & 29.0 & 36.5 & 38.8 & 39.8 & \\
\hline Grains & & & & & & & & 0.3 \\
\hline Low & 36.4 & 32.8 & 33.3 & 29.1 & 37.2 & 31.6 & 43.2 & \\
\hline Medium & 27.7 & 28.4 & 31.7 & 32.5 & 42.9 & 31.7 & 28.0 & \\
\hline High & 35.9 & 38.8 & 35.1 & 38.4 & 19.9 & 36.7 & 28.9 & \\
\hline
\end{tabular}




\begin{tabular}{|c|c|c|c|c|c|c|c|c|}
\hline Fruits & & & & & & & & 0.02 \\
\hline Low-medium & 35.1 & 34.7 & 37.1 & 37.5 & 41.4 & 42.5 & 36.3 & \\
\hline High & 65.0 & 65.3 & 62.9 & 62.6 & 58.5 & 57.5 & 63.7 & \\
\hline Vegetables & & & & & & & & $<0.001$ \\
\hline Low & 32.2 & 31.3 & 28.6 & 34.5 & 25.0 & 46.5 & 52.1 & \\
\hline Medium & 35.5 & 34.6 & 35.0 & 35.5 & 42.4 & 23.4 & 26.4 & \\
\hline High & 32.3 & 34.1 & 36.4 & 30.0 & 32.6 & 30.1 & 21.5 & \\
\hline Potatoes & & & & & & & & $<0.001$ \\
\hline Low & 30.6 & 43.9 & 32.6 & 23.5 & 21.5 & 13.2 & 17.7 & \\
\hline Medium & 41.4 & 31.6 & 36.0 & 33.3 & 35.9 & 44.5 & 29.0 & \\
\hline High & 28.0 & 24.6 & 31.4 & 43.2 & 42.5 & 42.2 & 53.2 & \\
\hline Dietary fat & & & & & & & & 0.06 \\
\hline Low & 28.5 & 33.9 & 34.3 & 22.5 & 30.3 & 39.0 & 35.3 & \\
\hline Medium & 31.5 & 28.5 & 31.6 & 31.0 & 30.3 & 26.0 & 28.5 & \\
\hline High & 40.1 & 37.7 & 34.0 & 46.5 & 39.3 & 35.0 & 36.3 & \\
\hline Soft drinks & & & & & & & & $<0.001$ \\
\hline Low & 23.6 & 36.3 & 34.7 & 28.6 & 18.5 & 21.5 & 20.9 & \\
\hline Medium & 40.6 & 41.4 & 36.1 & 28.7 & 33.2 & 30.7 & 45.4 & \\
\hline High & 35.8 & 22.3 & 29.2 & 42.7 & 48.4 & 47.8 & 33.7 & \\
\hline Water & & & & & & & & 0.007 \\
\hline Low & 21.0 & 26.0 & 22.2 & 32.4 & 16.0 & 24.5 & 28.0 & \\
\hline Medium & 43.6 & 36.7 & 40.9 & 35.7 & 52.6 & 52.6 & 37.3 & \\
\hline High & 35.4 & 37.3 & 36.9 & 31.9 & 31.4 & 22.8 & 34.6 & \\
\hline
\end{tabular}

Bold text indicates statistical significance 
Table 4.17: Distribution of the dietary factors by region (Cycle 3)

\begin{tabular}{|c|c|c|c|c|c|c|c|}
\hline Dietary variables & $\begin{array}{c}\text { Alberta } \\
\%\end{array}$ & $\begin{array}{c}\text { British } \\
\text { Columbia } \\
\%\end{array}$ & $\begin{array}{c}\text { Ontario } \\
\%\end{array}$ & $\begin{array}{c}\text { Quebec } \\
\%\end{array}$ & $\begin{array}{c}\text { New } \\
\text { Brunswick } \\
\%\end{array}$ & $\begin{array}{c}\text { Nova } \\
\text { Scotia } \\
\%\end{array}$ & p-value \\
\hline Red meat & & & & & & & $<0.001$ \\
\hline Low & 33.4 & 39.1 & 42.9 & 23.3 & 18.2 & 49.1 & \\
\hline Medium & 35.6 & 34.4 & 26.3 & 36.7 & 44.0 & 26.9 & \\
\hline High & 31.0 & 26.5 & 30.8 & 39.9 & 37.8 & 24.1 & \\
\hline Fish & & & & & & & 0.05 \\
\hline Low & 34.2 & 29.4 & 28.2 & 35.3 & 22.3 & 31.9 & \\
\hline Medium & 31.6 & 40.5 & 35.3 & 35.0 & 19.7 & 25.6 & \\
\hline High & 34.2 & 30.1 & 36.5 & 29.7 & 58.0 & 42.4 & \\
\hline Eggs & & & & & & & 0.15 \\
\hline Low & 26.9 & 13.8 & 22.7 & 20.0 & 21.2 & 18.9 & \\
\hline Medium & 35.7 & 37.4 & 40.3 & 48.5 & 33.1 & 36.7 & \\
\hline High & 37.3 & 48.7 & 37.1 & 31.5 & 45.7 & 44.4 & \\
\hline Beans & & & & & & & 0.01 \\
\hline Low & 27.8 & 22.6 & 35.5 & 36.0 & 45.5 & 48.8 & \\
\hline Medium & 33.0 & 33.1 & 34.0 & 35.0 & 28.0 & 23.6 & \\
\hline High & 39.2 & 44.4 & 30.6 & 29.0 & 26.5 & 27.6 & \\
\hline Milk & & & & & & & 0.35 \\
\hline Low & 30.3 & 42.7 & 36.9 & 34.1 & 30.0 & 23.5 & \\
\hline Medium & 37.4 & 28.6 & 32.3 & 34.7 & 33.2 & 29.2 & \\
\hline High & 32.3 & 28.7 & 30.8 & 31.2 & 36.8 & 47.3 & \\
\hline Grains & & & & & & & $<0.001$ \\
\hline Low & 42.6 & 30.7 & 39.7 & 24.6 & 19.8 & 30.3 & \\
\hline Medium & 29.6 & 37.6 & 34.0 & 39.3 & 42.5 & 41.0 & \\
\hline High & 27.8 & 31.8 & 26.3 & 36.1 & 37.7 & 28.7 & \\
\hline
\end{tabular}




\begin{tabular}{|c|c|c|c|c|c|c|c|}
\hline Fruits & & & & & & & 0.05 \\
\hline Low & 33.9 & 26.6 & 35.4 & 36.4 & 37.8 & 44.8 & \\
\hline Medium & 35.4 & 41.5 & 36.8 & 29.8 & 34.4 & 37.6 & \\
\hline High & 30.7 & 31.9 & 27.9 & 33.8 & 27.8 & 17.6 & \\
\hline Vegetables & & & & & & & $<0.001$ \\
\hline Low & 31.2 & 21.0 & 39.0 & 32.3 & 49.7 & 33.1 & \\
\hline Medium & 35.0 & 38.4 & 30.9 & 33.8 & 33.2 & 42.4 & \\
\hline High & 33.7 & 40.6 & 30.1 & 34.0 & 17.1 & 24.5 & \\
\hline Potatoes & & & & & & & 0.01 \\
\hline Low & 43.8 & 47.0 & 34.7 & 23.2 & 8.9 & 41.4 & \\
\hline Medium & 32.2 & 26.6 & 34.1 & 42.3 & 20.5 & 21.4 & \\
\hline High & 23.9 & 26.4 & 31.2 & 34.5 & 70.6 & 37.3 & \\
\hline Dietary fat & & & & & & & 0.24 \\
\hline Low & 40.3 & 50.1 & 39.8 & 27.0 & 22.5 & 18.3 & \\
\hline Medium & 29.6 & 33.1 & 28.4 & 36.9 & 22.4 & 41.0 & \\
\hline High & 30.1 & 16.9 & 31.8 & 36.1 & 55.1 & 40.7 & \\
\hline Soft drinks & & & & & & & 0.21 \\
\hline Low & 27.7 & 40.7 & 29.5 & 31.3 & 32.0 & 19.2 & \\
\hline Medium & 35.4 & 32.4 & 34.1 & 26.1 & 28.5 & 32.4 & \\
\hline High & 36.9 & 26.9 & 36.4 & 42.7 & 39.4 & 48.4 & \\
\hline Water & & & & & & & 0.03 \\
\hline Low & 14.3 & 23.6 & 22.2 & 30.0 & 25.8 & 26.7 & \\
\hline Medium & 46.4 & 41.9 & 36.8 & 44.2 & 38.9 & 29.4 & \\
\hline High & 39.4 & 34.5 & 41.0 & 25.8 & 35.3 & 43.9 & \\
\hline
\end{tabular}

Bold text indicates statistical significance 


\section{Appendix 3}

Analysis of demographic variables (without exposure of interest) with the outcomes/Main effects model

Table 4.18: Analysis of demographic variables (without exposure of interest) with FVC

\begin{tabular}{|c|c|c|c|c|c|c|c|c|c|}
\hline \multirow[t]{2}{*}{ Variables } & \multicolumn{3}{|c|}{ Cycle 1} & \multicolumn{3}{|c|}{ Cycle 2} & \multicolumn{3}{|c|}{ Cycle 3} \\
\hline & B & $\begin{array}{c}\text { Standard } \\
\text { error } \\
\text { (SE) }\end{array}$ & $\begin{array}{c}\mathrm{P}- \\
\text { value }\end{array}$ & $\boldsymbol{\beta}$ & $\begin{array}{c}\text { Standard } \\
\text { error } \\
\text { (SE) }\end{array}$ & $\begin{array}{c}\text { P- } \\
\text { value }\end{array}$ & $\boldsymbol{\beta}$ & $\begin{array}{c}\text { Standard } \\
\text { error } \\
\text { (SE) }\end{array}$ & $\begin{array}{c}\text { P- } \\
\text { value }\end{array}$ \\
\hline Age & -.026 & .002 & $<0.001$ & -.026 & .001 & $<0.001$ & -.025 & .002 & $<0.001$ \\
\hline $\operatorname{Sex}(2)$ & -.573 & .062 & $<0.001$ & -.576 & .057 & $<0.001$ & -.508 & .052 & $<0.001$ \\
\hline Race (2) & -.334 & .065 & $<0.001$ & -.404 & .066 & $<0.001$ & -.300 & .127 & 0.018 \\
\hline Height & .057 & .002 & $<0.001$ & .053 & .003 & $<0.001$ & .058 & .005 & $<0.001$ \\
\hline Immigrant (2) & -.003 & .024 & 0.91 & -.028 & .044 & 0.53 & .054 & .105 & 0.61 \\
\hline Marital status (2) & -.027 & .034 & 0.44 & .061 & .033 & 0.07 & -.043 & .045 & 0.34 \\
\hline \multicolumn{10}{|l|}{ Education } \\
\hline - Post-secondary graduation & .024 & .042 & 0.57 & .007 & .041 & 0.87 & .086 & .057 & 0.14 \\
\hline - Some post-secondary & -.020 & .060 & 0.74 & .099 & .098 & 0.31 & - & - & - \\
\hline $\begin{array}{l}\text { - Secondary } \\
\text { - Less than secondary (ref) }\end{array}$ & .088 & .039 & 0.022 & .028 & .065 & 0.67 & .003 & .078 & 0.96 \\
\hline \multicolumn{10}{|l|}{ Income } \\
\hline - $\mathrm{CAD}>80,000$ & .099 & .045 & 0.028 & .038 & .054 & 0.48 & -.114 & .064 & 0.08 \\
\hline - $\quad \mathrm{CAD} \geq 50,000$ to $<80,000$ & .030 & .045 & 0.51 & .032 & .051 & 0.53 & -.038 & .086 & 0.66 \\
\hline $\begin{array}{l}\text { - } \mathrm{CAD} \geq 30,000 \text { to }<50,000 \\
\text { - } \mathrm{CAD}<30,000 \text { (ref) }\end{array}$ & .035 & .046 & 0.45 & -.062 & .066 & 0.35 & -.171 & .044 & $<0.001$ \\
\hline \multicolumn{10}{|l|}{ BMI } \\
\hline - Obese & -.195 & .069 & 0.005 & -.215 & .054 & $<0.001$ & -.215 & .052 & $<0.001$ \\
\hline - Overweight & -.021 & .048 & 0.65 & -.058 & .043 & 0.18 & -.049 & .056 & 0.38 \\
\hline $\begin{array}{l}\bullet \quad \text { Not overweight or obese (ref) } \\
\text { Smoking }\end{array}$ & & & & & & & & & \\
\hline
\end{tabular}




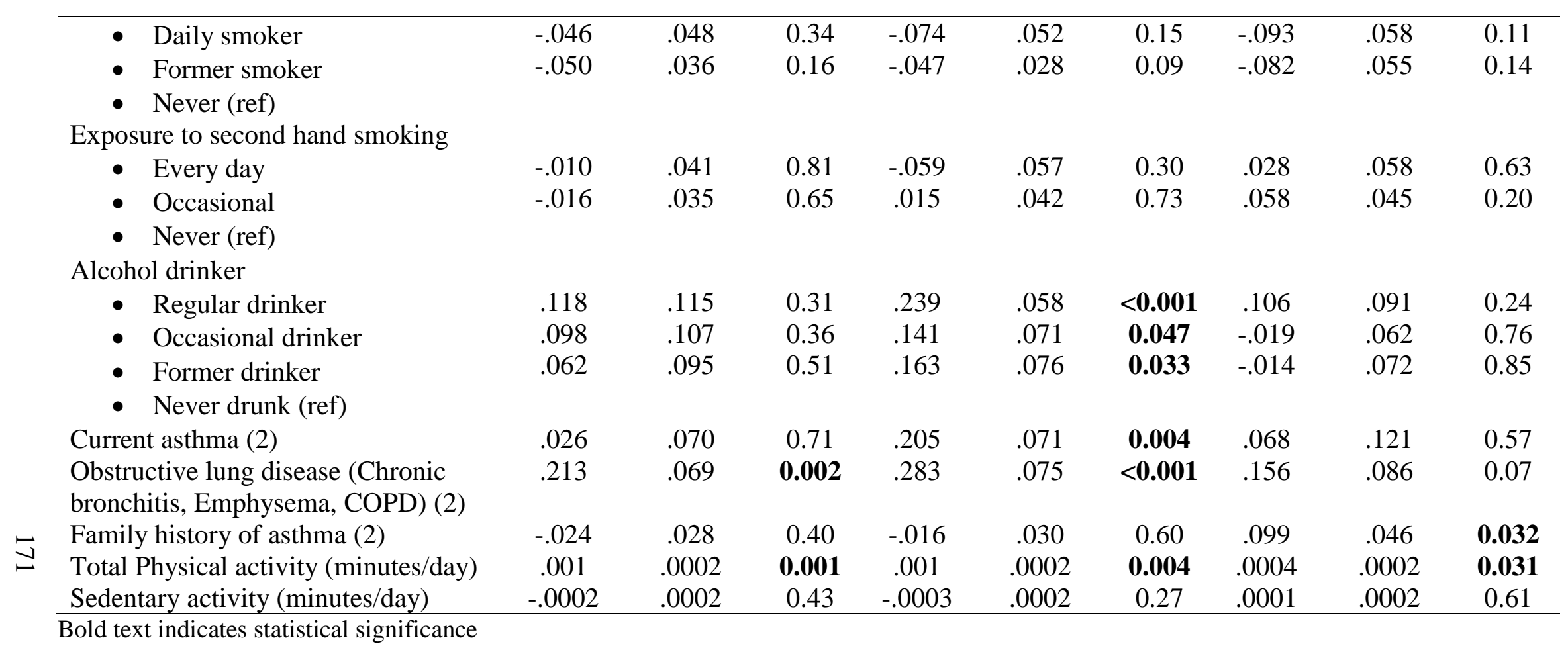


Table 4.19: Analysis of demographic variables (without exposure of interest) with $\mathrm{FEV}_{1}$

\begin{tabular}{|c|c|c|c|c|c|c|c|c|c|}
\hline \multirow[t]{2}{*}{ Variables } & \multicolumn{3}{|c|}{ Cycle 1} & \multicolumn{3}{|c|}{ Cycle 2} & \multicolumn{3}{|c|}{ Cycle 3} \\
\hline & B & $\begin{array}{c}\text { Standard } \\
\text { error } \\
\text { (SE) }\end{array}$ & $\begin{array}{c}P- \\
\text { value }\end{array}$ & $\beta$ & $\begin{array}{c}\text { Standard } \\
\text { error } \\
\text { (SE) }\end{array}$ & $\begin{array}{c}\mathbf{P}- \\
\text { value }\end{array}$ & $\beta$ & $\begin{array}{c}\text { Standard } \\
\text { error } \\
\text { (SE) }\end{array}$ & P-value \\
\hline Age & -.028 & .001 & $<0.001$ & -.026 & .001 & $<0.001$ & -.024 & .002 & $<0.001$ \\
\hline $\begin{array}{l}\text { Sex (2) } \\
\text { Race (2) } \\
\text { Height } \\
\text { Immigrant (2) }\end{array}$ & $\begin{array}{l}-.479 \\
-.208 \\
.036 \\
-.007\end{array}$ & $\begin{array}{l}.037 \\
.061 \\
.002 \\
.021\end{array}$ & $\begin{array}{c}<0.001 \\
0.001 \\
<0.001 \\
0.75\end{array}$ & $\begin{array}{l}-.452 \\
-.268 \\
.035 \\
-.029\end{array}$ & $\begin{array}{l}.047 \\
.050 \\
.003 \\
.030\end{array}$ & $\begin{array}{c}<0.001 \\
<0.001 \\
<0.001 \\
0.33\end{array}$ & $\begin{array}{l}-.384 \\
-.171 \\
.041 \\
.015\end{array}$ & $\begin{array}{l}.049 \\
.079 \\
.003 \\
.070\end{array}$ & $\begin{array}{c}<0.001 \\
\mathbf{0 . 0 3 1} \\
<\mathbf{0 . 0 0 1} \\
0.83\end{array}$ \\
\hline $\begin{array}{l}\text { Marital status (2) } \\
\text { Education }\end{array}$ & -.029 & .034 & 0.39 & .067 & .027 & 0.013 & -.020 & .029 & 0.50 \\
\hline $\begin{array}{l}\text { - Post-secondary graduation } \\
\text { - Some post-secondary } \\
\text { - Secondary } \\
\text { - Less than secondary (ref) }\end{array}$ & $\begin{array}{l}.053 \\
.014 \\
.110\end{array}$ & $\begin{array}{l}.042 \\
.076 \\
.054\end{array}$ & $\begin{array}{l}0.21 \\
0.85 \\
\mathbf{0 . 0 4 1}\end{array}$ & $\begin{array}{l}-.028 \\
.085 \\
-.017\end{array}$ & $\begin{array}{l}.040 \\
.099 \\
.051\end{array}$ & $\begin{array}{l}0.48 \\
0.39 \\
0.75\end{array}$ & $\begin{array}{c}.059 \\
- \\
-.013\end{array}$ & $\begin{array}{c}.059 \\
- \\
.070\end{array}$ & $\begin{array}{c}0.32 \\
- \\
0.85\end{array}$ \\
\hline 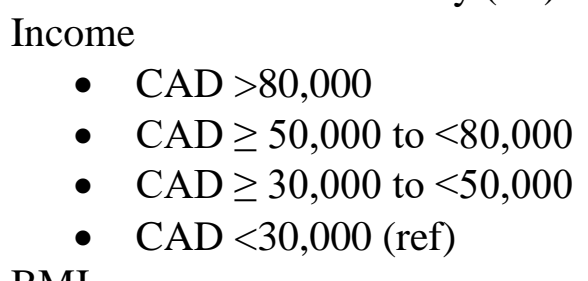 & $\begin{array}{c}.076 \\
-.001 \\
.001\end{array}$ & $\begin{array}{l}.041 \\
.043 \\
.032\end{array}$ & $\begin{array}{l}0.07 \\
0.98 \\
0.99\end{array}$ & $\begin{array}{c}.054 \\
.065 \\
-.043\end{array}$ & $\begin{array}{l}.043 \\
.042 \\
.060\end{array}$ & $\begin{array}{l}0.21 \\
0.12 \\
0.48\end{array}$ & $\begin{array}{l}.012 \\
.026 \\
-.033\end{array}$ & $\begin{array}{l}.073 \\
.081 \\
.063\end{array}$ & $\begin{array}{l}0.87 \\
0.75 \\
0.60\end{array}$ \\
\hline $\begin{aligned} \text { BMI } & \\
\text { - } & \text { Obese } \\
\text { - } & \text { Overweight } \\
\text { - } & \text { Not overweight or obese } \\
& \text { (ref) }\end{aligned}$ & $\begin{array}{c}-.066 \\
.034\end{array}$ & $\begin{array}{l}.041 \\
.027\end{array}$ & $\begin{array}{l}0.11 \\
0.21\end{array}$ & $\begin{array}{c}-.080 \\
.008\end{array}$ & $\begin{array}{l}.043 \\
.032\end{array}$ & $\begin{array}{l}0.06 \\
0.81\end{array}$ & $\begin{array}{l}-.118 \\
-.0005\end{array}$ & $\begin{array}{l}.055 \\
.049\end{array}$ & $\begin{array}{c}\mathbf{0 . 0 3 1} \\
0.99\end{array}$ \\
\hline $\begin{array}{l}\text { Smoking } \\
\text { - Daily smoker } \\
\text { - Former smoker } \\
\text { - Never (ref) }\end{array}$ & $\begin{array}{l}-.211 \\
-.068\end{array}$ & $\begin{array}{l}.053 \\
.033\end{array}$ & $\begin{array}{c}<0.001 \\
0.038\end{array}$ & $\begin{array}{l}-.204 \\
-.098\end{array}$ & $\begin{array}{l}.052 \\
.033\end{array}$ & $\begin{array}{c}<0.001 \\
0.003\end{array}$ & $\begin{array}{l}-.217 \\
-.087\end{array}$ & $\begin{array}{l}.058 \\
.044\end{array}$ & $\begin{array}{c}<0.001 \\
0.048\end{array}$ \\
\hline
\end{tabular}




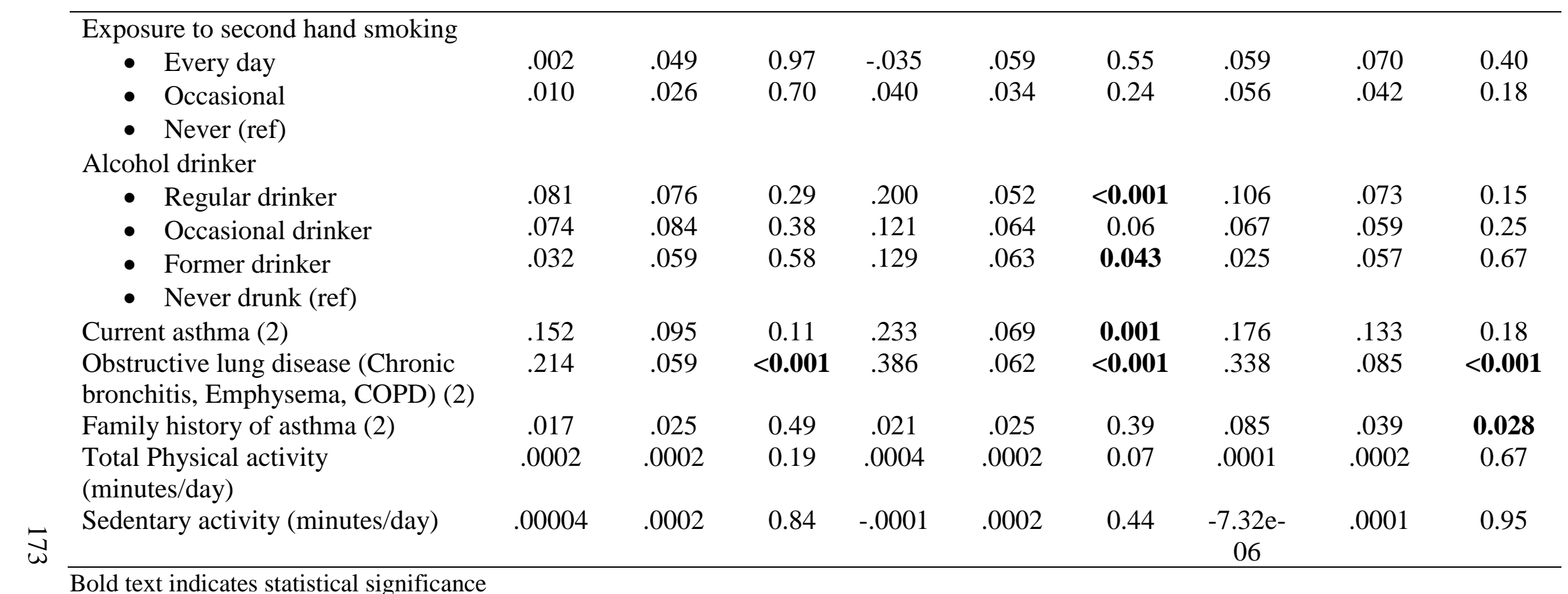

Bold text indicates statistical significance 
Table 4.20: Analysis of demographic variables (without exposure of interest) with $\mathrm{FEV}_{1} / \mathrm{FVC}$

\begin{tabular}{|c|c|c|c|c|c|c|c|c|c|}
\hline \multirow[t]{2}{*}{ Variables } & \multicolumn{3}{|c|}{ Cycle 1} & \multicolumn{3}{|c|}{ Cycle 2} & \multicolumn{3}{|c|}{ Cycle 3} \\
\hline & B & $\begin{array}{l}\text { Standar } \\
\text { d error } \\
\text { (SE) }\end{array}$ & $\begin{array}{c}\text { P- } \\
\text { value }\end{array}$ & $\boldsymbol{\beta}$ & $\begin{array}{l}\text { Standar } \\
\text { d error } \\
\text { (SE) }\end{array}$ & $\begin{array}{c}\text { P- } \\
\text { value }\end{array}$ & $\boldsymbol{\beta}$ & $\begin{array}{l}\text { Standar } \\
\text { d error } \\
\text { (SE) }\end{array}$ & P-value \\
\hline Age & -.002 & .0001 & $<0.001$ & -.002 & .0002 & $<0.001$ & -.001 & .0003 & $<0.001$ \\
\hline Sex (2) & -.005 & .005 & 0.33 & .001 & .004 & 0.87 & -.001 & .008 & 0.95 \\
\hline Race (2) & .013 & .006 & 0.030 & .015 & .007 & 0.038 & .022 & .006 & $<0.001$ \\
\hline Height & -.001 & .0004 & 0.002 & -.001 & .0003 & $<0.001$ & -.001 & .001 & 0.06 \\
\hline Immigrant (2) & -.006 & .003 & 0.047 & -.003 & .006 & 0.60 & -.003 & .005 & 0.48 \\
\hline Marital status (2) & -.006 & .004 & 0.10 & .006 & .005 & 0.22 & .0002 & .005 & 0.98 \\
\hline \multicolumn{10}{|l|}{ Education } \\
\hline - Post-secondary graduation & .011 & .007 & 0.11 & -.012 & .006 & 0.04 & -.003 & .008 & 0.72 \\
\hline - Some post-secondary & .014 & .012 & 0.25 & -.0004 & .009 & 0.96 & - & - & - \\
\hline $\begin{array}{l}\text { - Secondary } \\
\text { - } \quad \text { Less than secondary (ref) }\end{array}$ & .015 & .007 & $\mathbf{0 . 0 3 3}$ & -.012 & .005 & 0.026 & -.002 & .007 & 0.77 \\
\hline \multicolumn{10}{|l|}{ Income } \\
\hline - $\mathrm{CAD}>80,000$ & -.0003 & .005 & 0.96 & .010 & .008 & 0.20 & .023 & .011 & 0.035 \\
\hline - $\mathrm{CAD} \geq 50,000$ to $<80,000$ & -.006 & .006 & 0.32 & .012 & .007 & 0.06 & .012 & .010 & 0.22 \\
\hline $\begin{array}{ll}\text { - } & \mathrm{CAD} \geq 30,000 \text { to }<50,000 \\
\text { - } & \mathrm{CAD}<30,000 \text { (ref) }\end{array}$ & -.006 & .005 & 0.24 & .004 & .009 & 0.64 & .025 & .012 & 0.034 \\
\hline \multicolumn{10}{|l|}{ BMI } \\
\hline - Obese & .025 & .005 & $<0.001$ & .025 & .005 & $<0.001$ & .011 & .006 & 0.09 \\
\hline $\begin{array}{l}\text { - Overweight } \\
\text { - Not overweight or obese } \\
\text { (ref) }\end{array}$ & .013 & .004 & 0.003 & .015 & .003 & $<0.001$ & .006 & .005 & 0.28 \\
\hline \multicolumn{10}{|l|}{ Smoking } \\
\hline - Daily smoker & -.046 & .006 & $<0.001$ & -.039 & .007 & $<0.001$ & -.043 & .006 & $<0.001$ \\
\hline $\begin{array}{l}\text { - } \quad \text { Former smoker } \\
\text { - } \quad \text { Never (ref) }\end{array}$ & -.010 & .004 & 0.006 & -.018 & .005 & $<0.001$ & -.010 & .005 & 0.06 \\
\hline
\end{tabular}




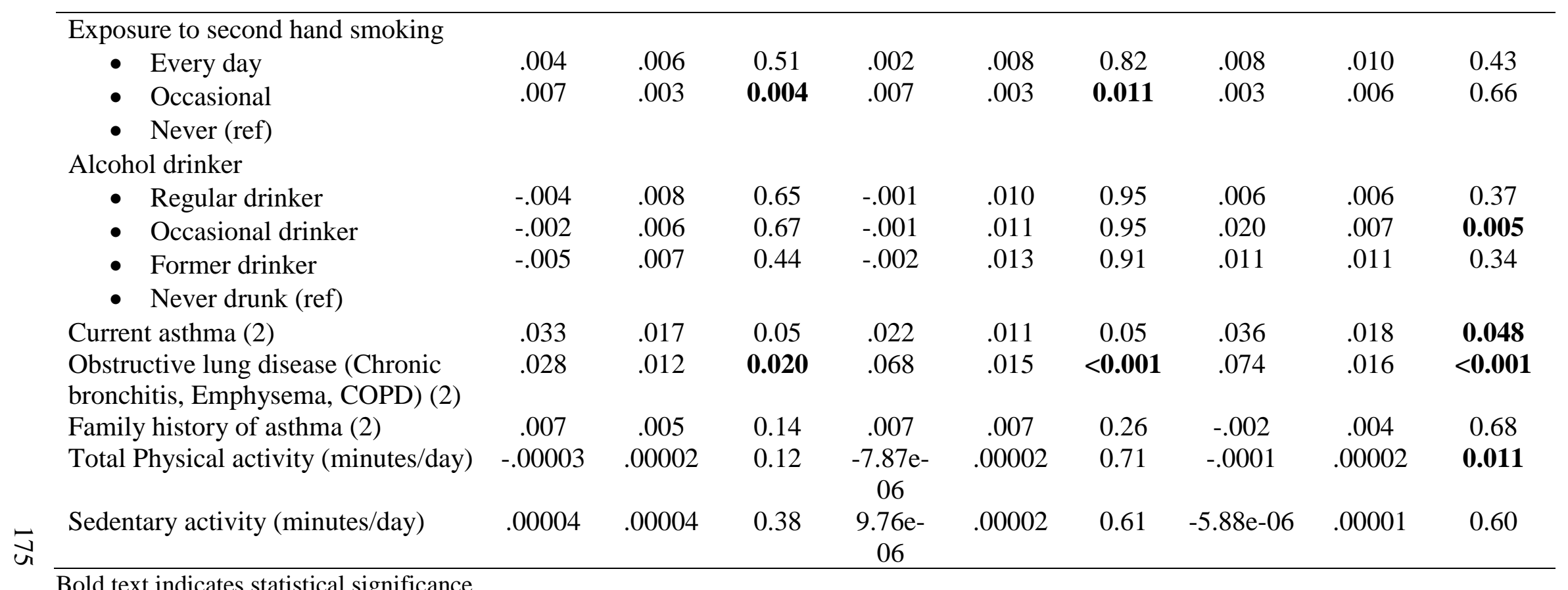

Bold text indicates statistical significance 
Table 4.21: Analysis of demographic variables (without exposure of interest) with $\mathrm{FEF}_{25-75 \%}$

\begin{tabular}{|c|c|c|c|c|c|c|c|c|c|}
\hline \multirow[t]{2}{*}{ Variables } & \multicolumn{3}{|c|}{ Cycle 1} & \multicolumn{3}{|c|}{ Cycle 2} & \multicolumn{3}{|c|}{ Cycle 3} \\
\hline & B & $\begin{array}{c}\text { Standard } \\
\text { error } \\
\text { (SE) }\end{array}$ & $\begin{array}{c}\text { P- } \\
\text { value }\end{array}$ & $\boldsymbol{\beta}$ & $\begin{array}{c}\text { Standard } \\
\text { error } \\
\text { (SE) }\end{array}$ & $\begin{array}{c}\text { P- } \\
\text { value }\end{array}$ & $\boldsymbol{\beta}$ & $\begin{array}{c}\text { Standard } \\
\text { error } \\
\text { (SE) }\end{array}$ & $\begin{array}{c}\text { P- } \\
\text { value }\end{array}$ \\
\hline Age & -.043 & .002 & $<0.001$ & -.035 & .002 & $<0.001$ & -.036 & .003 & $<0.001$ \\
\hline $\operatorname{Sex}(2)$ & -.509 & .055 & $<0.001$ & -.433 & .061 & $<0.001$ & -.438 & .086 & $<0.001$ \\
\hline Race (2) & -.090 & .109 & 0.41 & -.068 & .098 & 0.49 & -.0004 & .050 & 0.99 \\
\hline Height & .017 & .005 & 0.001 & .017 & .005 & 0.001 & .020 & .003 & $<0.001$ \\
\hline Immigrant (2) & -.041 & .042 & 0.33 & .001 & .067 & 0.99 & -.042 & .055 & 0.45 \\
\hline Marital status (2) & -.066 & .043 & 0.13 & .119 & .060 & 0.046 & -.010 & .070 & 0.88 \\
\hline \multicolumn{10}{|l|}{ Education } \\
\hline - Post-secondary graduation & .058 & .079 & 0.46 & -.092 & .100 & 0.36 & -.004 & .117 & 0.97 \\
\hline - Some post-secondary & .085 & .141 & 0.55 & .073 & .149 & 0.62 & - & - & - \\
\hline $\begin{array}{l}\text { - Secondary } \\
\text { - Less than secondary (ref) }\end{array}$ & .162 & .112 & 0.15 & -.085 & .101 & 0.40 & -.004 & .095 & 0.97 \\
\hline \multicolumn{10}{|l|}{ Income } \\
\hline - $\mathrm{CAD}>80,000$ & .036 & .056 & 0.52 & .118 & .061 & 0.06 & .171 & .124 & 0.17 \\
\hline - $\mathrm{CAD} \geq 50,000$ to $<80,000$ & -.044 & .054 & 0.41 & .136 & .055 & $\mathbf{0 . 0 1 3}$ & .130 & .106 & 0.22 \\
\hline $\begin{array}{ll}\text { - } & \mathrm{CAD} \geq 30,000 \text { to }<50,000 \\
\text { - } & \mathrm{CAD}<30,000 \text { (ref) }\end{array}$ & -.053 & .048 & 0.27 & .016 & .085 & 0.85 & .138 & .124 & 0.27 \\
\hline \multicolumn{10}{|l|}{ BMI } \\
\hline - Obese & .127 & .055 & 0.021 & .209 & .062 & 0.001 & .026 & .086 & 0.76 \\
\hline $\begin{array}{l}\text { - Overweight } \\
\text { - Not overweight or obese (ref) }\end{array}$ & .139 & .042 & 0.001 & .197 & .046 & $<0.001$ & .055 & .078 & 0.47 \\
\hline \multicolumn{10}{|l|}{ Smoking } \\
\hline - Daily smoker & -.523 & .080 & $<0.001$ & -.525 & .082 & $<0.001$ & -.523 & .103 & $<0.001$ \\
\hline $\begin{array}{l}\text { - Former smoker } \\
\text { - Never (ref) }\end{array}$ & -.147 & .064 & 0.022 & -.208 & .074 & 0.005 & -.150 & .067 & 0.025 \\
\hline Exposure to second hand smoking & & & & & & & & & \\
\hline
\end{tabular}




\begin{tabular}{|c|c|c|c|c|c|c|c|c|c|}
\hline - $\quad$ Every day & .016 & .065 & 0.802 & .026 & .095 & 0.782 & .057 & .123 & 0.645 \\
\hline $\begin{array}{l}\text { - Occasional } \\
\text { - Never (ref) }\end{array}$ & .097 & .039 & 0.012 & .119 & .053 & 0.026 & .052 & .073 & 0.477 \\
\hline \multicolumn{10}{|l|}{ Alcohol drinker } \\
\hline - Regular drinker & -.002 & .094 & 0.981 & .270 & .100 & 0.007 & .196 & .086 & 0.024 \\
\hline - Occasional drinker & -.003 & .101 & 0.976 & .218 & .118 & 0.065 & .294 & .097 & 0.002 \\
\hline $\begin{array}{ll}\text { - } & \text { Former drinker } \\
\text { - } & \text { Never drunk (ref) }\end{array}$ & -.123 & .092 & 0.184 & .190 & .130 & 0.143 & .212 & .097 & 0.028 \\
\hline Current asthma (2) & .301 & .198 & 0.128 & .344 & .125 & 0.006 & .405 & .236 & 0.086 \\
\hline $\begin{array}{l}\text { Obstructive lung disease (Chronic } \\
\text { bronchitis, Emphysema, COPD) (2) }\end{array}$ & .207 & .095 & 0.029 & .574 & .113 & $<0.001$ & .598 & .155 & $<0.001$ \\
\hline Family history of asthma (2) & .070 & .054 & 0.195 & .084 & .066 & 0.202 & .085 & .060 & 0.162 \\
\hline Total Physical activity (minutes/day) & -.0003 & .0003 & 0.305 & .00004 & .0003 & 0.904 & -.0004 & .0002 & 0.098 \\
\hline Sedentary activity (minutes/day) & .0005 & .0003 & 0.200 & -.00001 & .0003 & 0.961 & -.00004 & .0002 & 0.811 \\
\hline
\end{tabular}

Bold text indicates statistical significance 


\section{Appendix 4}

\section{Results summary by food group}

\section{Individual Dietary Factors:}

- $\quad$ Red meats

Consumption of red meat (high) was associated with higher $\mathrm{FEV}_{1} / \mathrm{FVC}$ ratio $(\mathrm{Cycle} 3: \beta=$ 0.009, $\mathrm{p}<0.05)$ and higher $\mathrm{FEF}_{25-75 \%}($ Cycle 3: $\beta=0.117, \mathrm{p}<0.05)$.

- Fish

There was no statistically significant association observed in between fish and lung function $\left(\mathrm{FEV}_{1}, \mathrm{FVC}, \mathrm{FEV}_{1} / \mathrm{FVC}\right.$ ratio, and $\left.\mathrm{FEF}_{25-75 \%}\right)$ in any of the Cycles (Cycle 1, 2, 3).

- Eggs

Consumption of eggs (high) was associated with higher FEV $1($ Cycle 1: $\beta=0.071, p<0.05)$ and higher $\mathrm{FEF}_{25-75 \%}(\mathrm{Cycle} 1: \beta=0.104, \mathrm{p}<0.05)$ but Consumption of eggs (high) was associated with lower $\mathrm{FEV}_{1}$ in Cycle $3(\beta=-0.070, \mathrm{p}<0.05)$.

- Beans

Consumption of eggs (high) was associated with higher FVC (Cycle 3: $\beta=0.108, \mathrm{p}<0.05)$ and higher $\mathrm{FEV}_{1}(\mathrm{Cycle} 3: \beta=0.082, \mathrm{p}<0.05)$.

- Milk

Consumption of milk (medium) was associated with higher $\mathrm{FEV}_{1}$ (Cycle 3: $\beta=0.094$, $\mathrm{p}<0.05)$, higher $\mathrm{FEV}_{1} / \mathrm{FVC}$ ratio $($ Cycle $3: \beta=0.013, \mathrm{p}<0.05)$, and higher $\mathrm{FEF}_{25-75 \%}(\mathrm{Cycle}$ 3: $\beta=0.175, p<0.05)$.

- Grains 
Consumption of grains (medium) was associated with higher FVC (Cycle 3: $\beta=0.124$, $\mathrm{p}<0.05)$ and higher FEV $1($ Cycle 3: $\beta=0.086, \mathrm{p}<0.05)$.

\section{- Fruits}

Consumption of fruits (high) was associated with higher FEV 1 (Cycle $3: \beta=0.096, \mathrm{p}<0.05)$, higher $\mathrm{FEV}_{1} / \mathrm{FVC}$ ratio $($ Cycle 2: $\beta=0.013, \mathrm{p}<0.05)$, and higher $\mathrm{FEF}_{25-75 \%}($ Cycle 2: $\beta=$ $0.125, \mathrm{p}<0.05)$.

- Vegetables

Consumption of vegetables (medium) was associated with higher FVC (Cycle 3: $\beta=0.087$, $\mathrm{p}<0.05)$ and higher FEV $1($ Cycle $3: \beta=0.061, \mathrm{p}<0.05)$.

\section{- Potatoes}

Consumption of potatoes (medium \& high) was associated with lower FVC (Cycle 3: $\beta=-$ 0.132 (medium), $p<0.05$ and $\beta=-0.125$ (high), $p<0.05$ ), lower FEV (Cycle 3: $\beta=-0.120$ (medium), $\mathrm{p}<0.05$ and $\beta=-0.110$ (high), $\mathrm{p}<0.05$ ), and lower $\mathrm{FEF}_{25-75 \%}$ (Cycle 3: $\beta=-0.183$ (medium), $\mathrm{p}<0.05$ and $\beta=-0.136$ (high), $\mathrm{p}<0.05$ ).

- Dietary fat

Consumption of dietary fat (high) was associated with higher FVC (Cycle 1: $\beta=0.098$, $\mathrm{p}<0.05$, Cycle 2: $\beta=0.132, \mathrm{p}<0.05)$ and $\mathrm{FEV}_{1}($ Cycle 2: $\beta=0.076, \mathrm{p}<0.05)$.

- Soft drinks

Consumption of soft drinks (high) was associated with lower FVC (Cycle 2: $\beta=-0.146$, $\mathrm{p}<0.05), \mathrm{FEV}_{1}($ Cycle 2: $\beta=-0.120, \mathrm{p}<0.05)$, and lower $\mathrm{FEF}_{25-75 \%}$ (Cycle 2: $\beta=-0.144$, $\mathrm{p}<0.05)$.

- Water 
Consumption of water (high) was associated with lower $\mathrm{FEV}_{1} / \mathrm{FVC}$ ratio (Cycle 1: $\beta=-$ 0.006, $\mathrm{p}<0.05)$ and lower $\mathrm{FEF}_{25-75 \%}($ Cycle $1: \beta=-0.135, \mathrm{p}<0.05)$. But Consumption of water (medium) was associated with higher $\mathrm{FEF}_{25-75 \%}$ in Cycle $2(\beta=0.156, \mathrm{p}<0.05)$.

\section{Canada Food Guide:}

- Vegetables and fruits

"Not meeting" the requirement of vegetables and fruits was associated with lower FEV 1 (Cycle 3: $\beta=-0.141, p<0.05)$.

- Grains

"Not meeting" the requirement of grains was associated with lower $\mathrm{FEV}_{1} / \mathrm{FVC}$ ratio (Cycle 2: $\beta=-0.064, p<0.05)$.

- Milk

There was no statistically significant association observed in between "Not meeting" the requirement of milk and lung function $\left(\mathrm{FEV}_{1}, \mathrm{FVC}, \mathrm{FEV}_{1} / \mathrm{FVC}\right.$ ratio, and $\mathrm{FEF}_{25-75 \%}$ ) in any of the Cycles (Cycle 1, 2, 3).

- Meats

"Not meeting" the requirement of meats was associated with lower FEV 1 (Cycle 1: $\beta=$ 0.062, $\mathrm{p}<0.05$ ), lower $\mathrm{FEV}_{1} / \mathrm{FVC}$ ratio $\left(\right.$ Cycle $1: \beta=-0.008, \mathrm{p}<0.05$ ), and lower $\mathrm{FEF}_{25-75 \%}$ (Cycle 1: $\beta=-0.145, \mathrm{p}<0.05)$.

\section{Modified Mediterranean Diet Score}

Modified Mediterranean Diet Score was associated with lower FVC (Cycle 3: $\beta=-0.017$, $\mathrm{p}<0.05)$ and lower FEV $1($ Cycle $3: \beta=-0.017, \mathrm{p}<0.05)$. 


\section{Biomarkers}

- $\quad \operatorname{Vitamin} D(\mathrm{nmol} / \mathrm{L})$

Vitamin D was associated with higher $\mathrm{FEV}_{1}($ Cycle 1: $\beta=0.001, \mathrm{p}<0.05$. Cycle 2: $\beta=0.002$, $\mathrm{p}<0.05)$ and higher $\mathrm{FEF}_{25-75 \%}($ Cycle 1: $\beta=0.002, \mathrm{p}<0.05)$ whereas associated with lower $\mathrm{FEV}_{1} / \mathrm{FVC}$ ratio (Cycle 3: $\left.\beta=-0.0001, \mathrm{p}<0.05\right)$.

- Chloride $(\mathrm{mmol} / \mathrm{L})$

Chloride was associated with higher FVC (Cycle 1: $\beta=0.008, p<0.05$. Cycle $2: \beta=0.026$, $\mathrm{p}<0.05$. Cycle 3: 0.031, $\mathrm{p}<0.05)$, higher $\mathrm{FEV}_{1}($ Cycle 1: $\beta=0.013, \mathrm{p}<0.05$. Cycle 2: $\beta=$ 0.022, $\mathrm{p}<0.05$. Cycle 3: 0.027, $\mathrm{p}<0.05)$, and higher $\mathrm{FEF}_{25-75 \%}($ Cycle 2: $\beta=0.028, \mathrm{p}<0.05)$.

- Potassium (mmol/L)

Potassium was associated with lower FVC (Cycle 2: $\beta=-0.128, \mathrm{p}<0.05)$ and lower FEV 1 (Cycle 2: $\beta=-0.090, \mathrm{p}<0.05)$.

- $\quad$-reactive protein $(\mathrm{mg} / \mathrm{L})$

C-reactive protein was associated with lower FVC (Cycle 1: $\beta=-0.037, p<0.05$. Cycle 3: $\beta=-0.027, p<0.05)$, lower FEV $1($ Cycle 1: $\beta=-0.032, p<0.05$. Cycle 3: $\beta=-0.033, p<0.05)$, and lower $\mathrm{FEF}_{25-75 \%}($ Cycle 1: -0.034, $\mathrm{p}<0.05$. Cycle 3: -0.046, $\mathrm{p}<0.05)$.

- High density lipoprotein $(H D L)(\mathrm{moml} / \mathrm{L})$

There was no statistically significant association observed in between HDL and lung function $\left(\mathrm{FEV}_{1}, \mathrm{FVC}, \mathrm{FEV}_{1} / \mathrm{FVC}\right.$ ratio, and $\left.\mathrm{FEF}_{25-75 \%}\right)$ in any of the Cycles (Cycle 1, 2, 3).

- Total cholesterol ( $\mathrm{mmol} / \mathrm{L})$ 
There was no statistically significant association observed in between total cholesterol and lung function $\left(\mathrm{FEV}_{1}, \mathrm{FVC}, \mathrm{FEV}_{1} / \mathrm{FVC}\right.$ ratio, and $\left.\mathrm{FEF}_{25-75 \%}\right)$ in any of the Cycles (Cycle 1, $2,3)$.

- $\quad$ Total protein $(g / L)$

Total protein was associated with lower FVC (Cycle 2: $\beta=-0.010, p<0.05)$ and higher $\mathrm{FEF}_{25-75 \%}($ Cycle 3: $\beta=0.026, \mathrm{p}<0.05)$.

- $\operatorname{Sodium}(\mathrm{mmol} / \mathrm{L})$

Sodium was associated with lower $\mathrm{FEF}_{25-75 \%}($ Cycle 2: $\beta=-0.34, \mathrm{p}<0.05)$.

- $\operatorname{Calcium}(\mathrm{mmol} / \mathrm{L})$

Calcium was associated with higher $\mathrm{FEV}_{1}($ Cycle $2: \beta=0.537, \mathrm{p}<0.05)$, higher $\mathrm{FEV}_{1} / \mathrm{FVC}$ ratio (Cycle 3: $\beta=0.002, p<0.05)$, and higher $\mathrm{FEF}_{25-75 \%}($ Cycle 2: $\beta=1.034, \mathrm{p}<0.05)$.

- Red blood cell folate $(\mathrm{nmol} / \mathrm{L})$

Red blood cell folate was associated with higher $\mathrm{FEV}_{1}($ Cycle 3: $\beta=0.0001, \mathrm{p}<0.05)$ and lower $\mathrm{FEV}_{1} / \mathrm{FVC}$ ratio $($ Cycle $2: \beta=-0.003, \mathrm{p}<0.05)$.

- Vitamin B12 (pmol/L)

Vitamin B12 was associated with lower FVC (Cycle 3: $\beta=-0.0002$, p $<0.05)$, lower FEV 1 (Cycle 1: $\beta=-0.0002, p<0.05$. Cycle 3: $\beta=-0.0002, p<0.05$ ), higher $\mathrm{FEV}_{1} / \mathrm{FVC}$ ratio (Cycle 2: $\beta=0.087, \mathrm{p}<0.05)$, and lower $\mathrm{FEF}_{25-75 \%}($ Cycle $1: \beta=-0.0004, \mathrm{p}<0.05)$. 